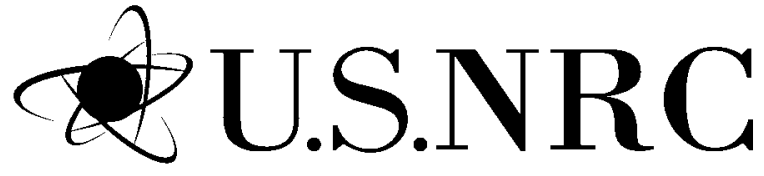

NUREG/CR-7018

ANL-09/17

United States Nuclear Regulatory Commission

Protecting People and the Environment

\title{
Irradiation-Assisted Stress Corrosion Cracking of Austenitic Stainless Steels in BWR Environments
}



United States Nuclear Regulatory Commission

$\overline{\text { Protecting People and the Environment }}$

\section{Irradiation-Assisted Stress Corrosion Cracking of Austenitic Stainless Steels in BWR Environments}

Manuscript Completed: February 2009

Date Published: June 2010

Prepared by

Y. Chen, O.K. Chopra, E.E. Gruber and W.J. Shack

Argonne National Laboratory

9700 South Cass Avenue

Argonne, IL 60439

A.S. Rao, NRC Project Manager

NRC Job Code N6519 
This page is intentionally left blank. 


\section{Abstract}

The internal components of light water reactors are exposed to high-energy neutron irradiation and high-temperature reactor coolant. The exposure to neutron irradiation increases the susceptibility of austenitic stainless steels (SSs) to stress corrosion cracking (SCC) because of the elevated corrosion potential of the reactor coolant and the introduction of new embrittlement mechanisms through radiation damage. Various nonsensitized SSs and nickel alloys have been found to be prone to intergranular cracking after extended neutron exposure. Such cracks have been seen in a number of internal components in boiling water reactors (BWRs). The elevated susceptibility to SCC in irradiated materials, commonly referred to as irradiation-assisted stress corrosion cracking (IASCC), is a complex phenomenon that involves simultaneous actions of irradiation, stress, and corrosion. In recent years, as nuclear power plants have aged and irradiation dose increased, IASCC has become an increasingly important issue. Post-irradiation crack growth rate and fracture toughness tests have been performed to provide data and technical support for the NRC to address various issues related to aging degradation of reactor-core internal structures and components. This report summarizes the results of the last group of tests on compact tension specimens from the Halden-II irradiation. The IASCC susceptibility of austenitic SSs and heat-affected-zone (HAZ) materials sectioned from submerged arc and shielded metal arc welds was evaluated by conducting crack growth rate and fracture toughness tests in a simulated BWR environment. The fracture and cracking behavior of HAZ materials, thermally sensitized SSs and grain-boundary engineered SSs was investigated at several doses ( $\leq 3 \mathrm{dpa})$. These latest results were combined with previous results from Halden-I and II irradiations to analyze the effects of neutron dose, water chemistry, alloy compositions, and welding and processing conditions on IASCC. The effect of neutron irradiation on the fracture toughness of austenitic SSs was also evaluated at dose levels relevant to BWR internals.

\section{Paperwork Reduction Act Statement}

This NUREG does not contain information collection requirements and, therefore, is not subject to the requirements of the Paperwork Reduction Act of 1995 (44 U.S.C. 3501 et seq.).

\section{Public Protection Notification}

The NRC may not conduct or sponsor, and a person is not required to respond to, a request for information or an information collection requirement unless the requesting document displays a current valid OMB control number. 
This page is intentionally left blank. 


\section{Foreword}

The internal components of light water reactors are exposed to high-energy neutron irradiation and hightemperature reactor coolant. The exposure to neutron irradiation increases the susceptibility of austenitic stainless steels (SSs) to irradiation-assisted stress corrosion cracking (IASCC). Similarly, the radiation damage may induce embrittlement and reduce the material's resistance to crack propagation. Various non-sensitized SSs and nickel alloys have been shown to be susceptible to IASCC and embrittlement after extended neutron exposure in laboratory environments. Additionally, cracks caused by IASCC have been found in a number of internal components in boiling water reactors (BWRs). As nuclear power plants age and neutron irradiation dose increases, IASCC and embrittlement become more likely and are an important safety consideration in the long-term operation of nuclear power plants.

IASCC is a complex phenomenon that results from the interaction of irradiation, stress, and corrosion. This report examines the effects of simulated light-water reactor environments, material chemistry, and irradiation damage on the IASCC susceptibility of a series of commercially available and laboratorymelted stainless steels. This report is the final report in its series dating back approximately 8 years. Some of the earlier publications in this series include NUREG/CR 5608, "Irradiation-Assisted Stress Corrosion Cracking of Model Austenitic Stainless Steels Irradiated in the Halden Reactor"; NUREG/CR6892, "Fracture Toughness and Crack Growth Rates of Irradiated Austenitic Stainless Steels"; NUREG/CR-6687, "Irradiation-Assisted Stress Corrosion Cracking of Model Austenitic Stainless Steel Alloys"; NUREG/CR- 6915, "Irradiation-Assisted Stress Corrosion Cracking of Austenitic Stainless Steels and Alloy 690 from Halden Phase-II Irradiations" and NUREG/CR-6960, "Crack Growth Rates and Fracture Toughness of Irradiated Austenitic Stainless Steels in BWR Environments."

The Halden - Phase I irradiation principally evaluated stainless steels having a wide-range of chemical compositions (including commercial steels of typical chemistry) with conventional heat treatment and product form processing. The Halden - Phase II irradiation included a plurality of innovatively fabricated and engineered alloys intended to be more resistant to IASCC. Specially, these irradiations studied austenitic SSs, such as Types 304 and 316 (and their low carbon counterparts), grain boundary engineered (GBE) SSs, submerged arc and shield metal arc welds, and the heat-affected zone (HAZ) materials sectioned from these welds. The IASCC susceptibility of these materials was evaluated by conducting crack growth rate and fracture toughness tests in simulated BWR environments (fluence range up to 3 dpa; and dissolved oxygen in the water $200 \mathrm{ppb}$ to $8 \mathrm{ppm}$ ).

In NUREG/CR-6892, it was found that sulfur (S) content below $0.002 \mathrm{wt} . \%$ provides the best resistance to IASCC in SSs. In contrast, IASCC susceptibility increased dramatically in SSs that contain greater than 0.003 wt. \% S. A sufficiently low S concentration is the most important factor for ensuring that a SS has good IASCC resistance. The earlier test data also suggest that moderately high carbon content (i.e., $>0.03 \mathrm{wt} \%$ ) ensures good resistance to IASCC content.. From the above two observations, it is reasonable to infer that both moderately high carbon $(>0.03 \mathrm{wt} . \%)$ and low sulfur $(<0.002 \mathrm{wt} . \%)$ are necessary to provide sufficient IASCC resistance in Type 304 and 316 steels. This is an important finding, given that many stainless steels (Type 304L or 316L) are decarburized to protect against thermal sensitization; too low a carbon level $(<0.03 \mathrm{wt} . \%)$ could render such steels susceptible to IASCC.

In this report, it is demonstrated that although highly irradiated SSs exhibit strain softening, the effect on the plastic zone size ahead of a crack tip is only minimally increased. The increase in yield strength due to irradiation more than compensates for this effect such that valid crack growth rate and fracture toughness measurements are achieved in small test specimens. Results also show that, for a Type $304 \mathrm{SS}$ 
sensitized at $600^{\circ} \mathrm{C}$ for 10.5 and 24 hours, the degree of sensitization has a negligible effect on IASCC resistance. Also, the GBE treatment (the fraction of coincident-site-lattice boundaries $\sim 60 \%$ ) did not improve IASCC susceptibility in the test materials and environment. Conversely, increasing the neutron fluence significantly decreased both the IASCC resistance and the fracture toughness.

The research described in this report provides relevant test data and technical support for NRC to analyze the integrity of reactor-core internal structures and components which are subjected to IASCC.

Specifically, results of this final report can be used to support the evaluation of the acceptability of reactor internal aging management programs in license renewal applications. The results may also be used to determine appropriate inspection and flaw disposition procedures for reactor internals that can be used in ASME code development and to support any needed conditions within Title 10, Section 50.55a, "Codes and Standards," of the Code of Federal Regulations (10CFR 5055a). Finally, the results are also useful for identifying issues related to long-term operation (i.e., greater than 60 years) in nuclear power plants.

\author{
Michael Case, Director \\ Division of Engineering \\ Office of Nuclear Regulatory Research \\ U.S. Nuclear Regulatory Commission
}




\section{Contents}

Abstract.

Foreword.

Figures ix

Tables $\mathrm{XV}$

Executive Summary xvii

Acknowledgments. xxi

Acronyms and Abbreviations

xxiii

1 Introduction

2 Experimental.

2.1 Compact Tension Specimens and Materials.

2.2 Irradiation

2.3 Test Facility

2.4 Test Procedures

2.4.1 Crack Growth Rate Test

2.4.2 Model for Crack Growth Rate Test Analysis

2.4.3 Fracture Toughness J-R Curve Tests.....

3 Experimental Results

3.1 Thermally Treated Type 304L SA Weld HAZ Irradiated to 2.4 dpa (GG3TA-TT)........ 15

3.2 Type 304 SMA Weld HAZ

3.2.1 As-welded Type 304 SMA Weld HAZ Irradiated to 0.75 dpa (85-7B)

3.2.2 Thermally Treated Type 304 SMA Weld HAZ Irradiated to 2 dpa (85-2ATT).....

3.3 Sensitized Type 304 SS Irradiated to $0.75 \mathrm{dpa} .$.

3.3.1 Type $304 \mathrm{SS}$ Sensitized at $600^{\circ} \mathrm{C}$ for $10.5 \mathrm{~h}(85-1 \mathrm{TT})$ 


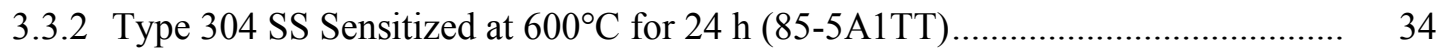

3.4 Type 304 SS with and without GBE Treatment ................................................... 38

3.4.1 Type 304 SS without GBE Treatment (IT304-01) …...................................... 38

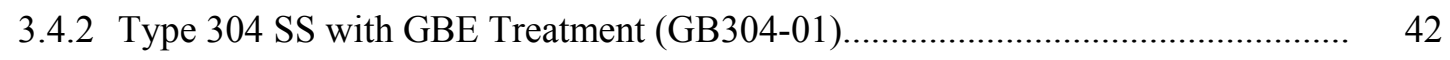

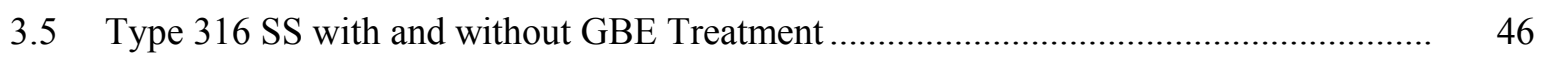

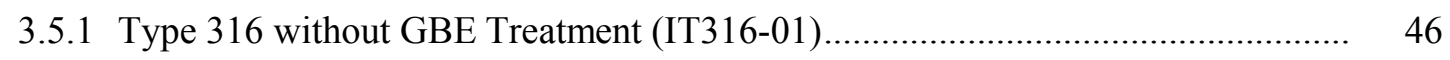

3.5.2 Type 316 SS with GBE Treatment (GB316-01) ............................................. 50

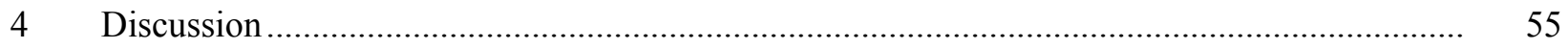

4.1 Specimen Size Criteria Relevant to Cyclic and Constant-Load CGR Tests.................... 55

4.2 Effects of Weld Process on Cracking Behavior ........................................................ 57

4.2.1 Cyclic CGR for Nonirradiated Weld HAZs .................................................. 57

4.2.2 Cyclic CGR for Irradiated Weld HAZ Materials............................................. 58

4.2.3 Constant-Load CGR for Nonirradiated and Irradiated Weld HAZ Specimens ...... 59

4.2.4 Fracture Toughness of Weld HAZ Specimens ................................................. 61

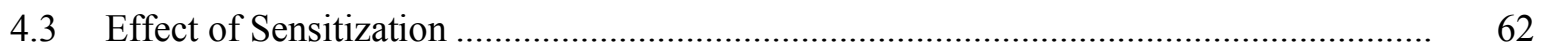

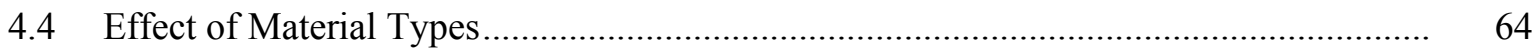

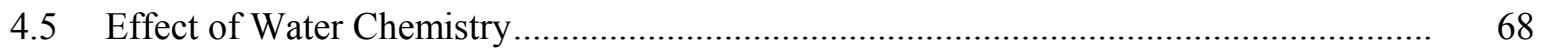

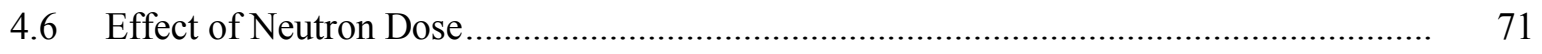

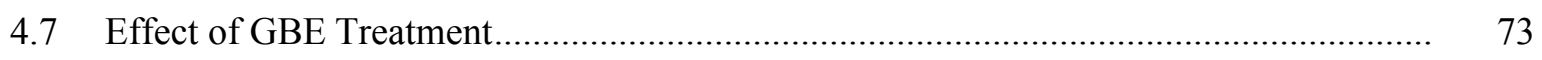

4.7.1 Crack Growth Rates for GBE and Non-GBE Type 304 and 316 SSs .................. 73

4.7.2 Fracture Toughness of GBE and Non-GBE Type 304 and 316 SSs...................... 75

4.7.3 Hardness and Microstructure of Nonirradiated GBE and Non-GBE Type 304 and 316 SSs ......................................................................................... 75

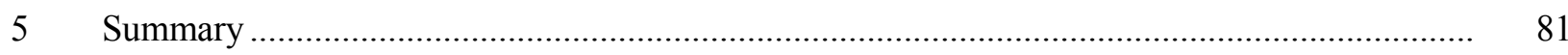

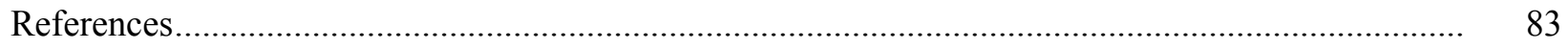




\section{Figures}

1. Susceptibility of irradiated austenitic SSs to intergranular SCC as a function of fluence in high-DO water. Data from slow-strain-rate tensile tests.

2. Configuration of compact-tension specimen used in this study (dimensions in mm)............... 5

3. Weld microstructure in the (a) Grand Gulf SA weld and (b) laboratory-prepared SMA weld... 6

4. Mechanical test system for conducting CGR and J-R tests on radioactive specimens.............. 8

5. A schematic diagram of the water recirculation system. ...................................................

6. Crack-length-vs.-time plot for the thermally treated GG $304 \mathrm{~L} \mathrm{SA} \mathrm{HAZ} \mathrm{specimen}(\approx 2.4 \mathrm{dpa})$ in simulated BWR water at $289^{\circ} \mathrm{C}$.

7. Crack growth rate for GG 304L SA HAZ specimen under cyclic load in simulated BWR $\mathrm{NWC}$ water at $\approx 290^{\circ} \mathrm{C}$

8. Crack growth rate versus stress intensity under constant-loading condition for the 304L SA $\mathrm{HAZ}$ specimen thermally treated at $500^{\circ} \mathrm{C}$ for $24 \mathrm{~h}$ (GG3TA-TT) in simulated BWR NWC and $\mathrm{HWC}$ water at $\approx 290^{\circ} \mathrm{C}$.

9. Load vs. load-line displacement curve for the thermally treated 304L SA HAZ specimen (GG3TA-TT) tested in NWC at $289^{\circ} \mathrm{C}$.

10. Fracture toughness J-R result for the thermally treated 304L SA HAZ specimen (GG3TATT) tested in NWC at $289^{\circ} \mathrm{C}$.

11. Photograph of the fracture surface of the thermally treated 304L SA HAZ specimen (GG3TA-TT).

12. Crack-length-vs.-time plot for the as-welded Type 304 SMA HAZ specimen $(85-7 \mathrm{~B}, \sim 0.75$ dpa) in BWR water at $289^{\circ} \mathrm{C}$.

13. Cyclic crack growth rate for the as-welded Type 304 SMA HAZ specimen (85-7B) irradiated to $0.75 \mathrm{dpa}$.

14. Crack growth rate versus stress intensity under constant-loading conditions for the as-welded Type 304 SMA HAZ specimen (85-7B) irradiated to $0.75 \mathrm{dpa}$.

15. Temperature dependence of crack growth rate for the as-welded 304 SMA HAZ specimen $(85-7 \mathrm{~B}, 0.75 \mathrm{dpa})$

16. Load vs. load-line displacement curve for the as-welded Type 304 SMA HAZ specimen (857B) tested in NWC at $289^{\circ} \mathrm{C}$. 
17. Fracture toughness J-R curves for the as-welded Type 304 SMA HAZ specimen (85-7B) tested in NWC at $289^{\circ} \mathrm{C}$

18. Photograph of the fracture surface of the as-welded 304 SMA HAZ specimen (85-7B) irradiated to $0.75 \mathrm{dpa}$.

19. Crack-length-vs.-time plot for the thermally treated Type 304 SMA HAZ specimen (852ATT, $\sim 2 \mathrm{dpa}$ ) in BWR water at $289^{\circ} \mathrm{C}$.

20. Cyclic CGRs for the thermally treated Type 304 SS SMA weld HAZ specimen (85-2ATT) irradiated to $2.1 \mathrm{dpa}$.

21. Constant-load CGRs for the thermally treated Type 304 SS SMA weld HAZ specimen (852ATT) irradiated to $2.1 \mathrm{dpa}$.

22. (a) Load vs. load-line displacement and (b) fracture toughness J-R curve for the thermally treated 304 SMA weld HAZ specimen (85-2ATT).

23. Optical images of the thermally treated 304 SS SMA HAZ specimen (85-2ATT) After fracturing: (a) fracture surface and (b) side view.

24. Crack-length-vs.-time plot for the Type $304 \mathrm{SS}$ specimen sensitized at $600^{\circ} \mathrm{C}$ for $10.5 \mathrm{~h}(85-$ $1 \mathrm{TT}, \sim 0.75 \mathrm{dpa}$ ) in BWR water at $289^{\circ} \mathrm{C}$.

25. Cyclic CGR for the Type 304 specimen sensitized at $600^{\circ} \mathrm{C}$ for $10.5 \mathrm{~h}(85-1 \mathrm{TT})$ and irradiated to $0.75 \mathrm{dpa}$.

26. Crack growth rate versus stress intensity under constant-loading conditions for the Type 304 specimen sensitized at $600^{\circ} \mathrm{C}$ for $10.5 \mathrm{~h}(85-1 \mathrm{TT})$ and irradiated to $0.75 \mathrm{dpa}$.

27. Load vs. load-line displacement curve for the Type 304 specimen sensitized at $600^{\circ} \mathrm{C}$ for $10.5 \mathrm{~h}(85-1 \mathrm{TT})$ and tested in NWC at $289^{\circ} \mathrm{C}$.

28. Fracture toughness J-R curve for the Type 304 specimen sensitized at $600^{\circ} \mathrm{C}$ for $10.5 \mathrm{~h}(85$ $1 \mathrm{TT}$ ) and tested in $\mathrm{NWC}$ at $289^{\circ} \mathrm{C}$

29. Photograph of the fracture surface of the Type 304 specimen sensitized at $600^{\circ} \mathrm{C}$ for $10.5 \mathrm{~h}$ (85-1 TT) and irradiated to $0.75 \mathrm{dpa}$

30. Crack-length-vs.-time plot for the Type $304 \mathrm{SS}$ specimen sensitized at $600^{\circ} \mathrm{C}$ for $24 \mathrm{~h}(85$ $5 \mathrm{~A} 1 \mathrm{TT}, \sim 0.75 \mathrm{dpa})$ in BWR water.

31. Cyclic CGR for the Type 304 specimen sensitized at $600^{\circ} \mathrm{C}$ for $24 \mathrm{~h}(85-5 \mathrm{~A} 1 \mathrm{TT})$ and irradiated to $0.75 \mathrm{dpa}$.

32. Crack growth rate versus stress intensity under constant-loading conditions for the Type 304 specimen sensitized at $600^{\circ} \mathrm{C}$ for $24 \mathrm{~h}(85-5 \mathrm{~A} 1 \mathrm{TT})$ and irradiated to $0.75 \mathrm{dpa}$. 
33. Photograph of the fracture surface of the Type 304 specimen sensitized at $600^{\circ} \mathrm{C}$ for $24 \mathrm{~h}$ (85-5A1TT) and irradiated to $0.75 \mathrm{dpa}$

34. Temperature dependence of CGR for the Type 304 specimen sensitized at $600^{\circ} \mathrm{C}$ for $24 \mathrm{~h}$ (85-5A1TT, $0.75 \mathrm{dpa})$

35. Crack-length-vs.-time plot for the base heat of Type 304 SS specimen (IT304-01, 2 dpa) in BWR water at $289^{\circ} \mathrm{C}$.

36. Cyclic CGR for the base heat of Type 304 SS specimen (IT304-01) irradiated to 2 dpa.

37. Crack growth rate versus stress intensity under constant-loading conditions for the base heat of Type 304 SS specimen (IT304-01) irradiated to 2 dpa.

38. Load vs. load-line displacement curve for the base heat of Type 304 SS specimen (IT304-01) tested in $\mathrm{NWC}$ at $289^{\circ} \mathrm{C}$

39. Fracture toughness J-R curves for the base heat of Type 304 SS specimen (IT304-01) tested in NWC at $289^{\circ} \mathrm{C}$.

40. Photograph of the fracture surface of the base heat of Type 304 SS (IT304-01) irradiated to 2 dpa.

41. Crack-length-vs.-time plot for the GBE-treated Type 304 SS specimen (GB304-01, $\approx 2$ dpa) in BWR water at $289^{\circ} \mathrm{C}$.

42. Cyclic crack growth rate for the GBE-treated Type 304 SS specimen (GB304-01) irradiated to 2 dpa.

43. Crack growth rate versus stress intensity under constant-loading conditions for the GBEtreated Type 304 SS specimen (GB304-01) irradiated to 2 dpa.

44. Load vs. load-line displacement curve for the GBE-treated Type 304 SS (GB304-01, 2 dpa) tested in NWC at $289^{\circ} \mathrm{C}$

45. Fracture toughness J-R curves for the GBE-treated Type 304 SS (GB304-01, 2 dpa) tested in $\mathrm{NWC}$ at $289^{\circ} \mathrm{C}$

46. Photograph of the fracture surface of the GBE-treated Type 304 SS (GB304-01) irradiated to 2 dpa.

47. Crack-length-vs.-time plot for the base heat of Type 316 SS specimen (IT316-01, $\approx 2$ dpa) in BWR water at $289^{\circ} \mathrm{C}$.

48. Cyclic CGR for the base heat of Type 316 SS (IT316-01) irradiated to 2 dpa.

49. Crack growth rate versus stress intensity under constant-loading conditions for the base heat of Type 316 SS (IT316-01) irradiated to 2 dpa. 
50. Load vs. load-line displacement curve for the base heat of Type 316 SS (IT316-01) tested in $\mathrm{NWC}$ at $289^{\circ} \mathrm{C}$

51. Fracture toughness J-R curve for the base heat of Type 316 SS (IT316-01) tested in NWC at $289^{\circ} \mathrm{C}$.

52. Photograph of the fracture surface of the base heat of Type 316 SS (IT316-01) irradiated to 2 dpa.

53. Crack-length-vs.-time plot for the GBE-treated Type 316 SS (GB316-01, $\approx 2$ dpa) tested in BWR water at $289^{\circ} \mathrm{C}$.

54. Cyclic CGR for the GBE-treated Type 316 SS (GB316-01) irradiated to 2 dpa.

55. Crack growth rate versus stress intensity under constant-loading conditions for the GBEtreated Type 316 SS (GB316-01) irradiated to 2 dpa.

56. Load vs. load-line displacement curve for the GBE-treated Type 316 SS (GB316-01, $\approx 2$ dpa) tested in $\mathrm{NWC}$ at $289^{\circ} \mathrm{C}$.

57. Fracture toughness J-R curves for the GBE-treated Type 316 SS (GB316-01, $\approx 2$ dpa) tested in NWC at $289^{\circ} \mathrm{C}$

58. Photograph of the fracture surface of the GBE-treated Type 316 SS (GB316-01) irradiated to 2 dpa.

59. Stress distribution ahead of a two-dimensional crack in a work-softened material.

60. Cyclic CGRs for non-irradiated SA and SMA weld HAZ specimens under the as-welded and thermally treated conditions.

61. Cyclic CGRs for SA and SMA weld HAZ specimens under as-welded condition irradiated to (a) 0.75 dpa, and (b) $\approx 2$ dpa.

62. Cyclic CGRs for thermally treated and as-welded (a) SMA HAZ specimens at 0.75 dpa and (b) SA HAZ specimens at 2 dpa.

63. Constant-load CGR versus stress intensity for nonirradiated SA and SMA weld HAZ specimens with and without heat treatment.

64. Constant-load CGR results versus stress intensity for SA and SMA HAZ specimens irradiated to (a) $0.75 \mathrm{dpa}$ and (b) $\approx 2 \mathrm{dpa}$

65. Fracture toughness of irradiated Type 304L SA and 304 SMA weld HAZ specimens tested in NWC BWR water.

66. Cyclic CGRs for sensitized Type 304 SS irradiated to 0.75 and 2 dpa. 
67. Constant-load CGRs versus stress intensity of sensitized Type 304 SS irradiated to 0.75 and 2 dpa

68. Cyclic CGRs for austenitic SSs irradiated to (a) $0.45 \mathrm{dpa}$, (b) $1.35 \mathrm{dpa}$, and (c) $3 \mathrm{dpa}$.

69. Constant-load CGRs versus stress intensity for austenitic SSs irradiated to (a) 0.45 dpa, (b) $1.35 \mathrm{dpa}$, and (c) $3 \mathrm{dpa}$.

70. Cyclic CGRs for Type 304L and 316L SSs in NWC and HWC tests.

71. Constant-load CGRs versus stress intensity in NWC and HWC for (a) weld HAZ, (b) sensitized 304 SS, and (c) wrought SSs.

72. Dose dependence of cyclic CGRs for Type 304L and 316 SSs.

73. Constant-load CGRs versus stress intensity for Type 304L, 316 and 316L SSs at different doses.

74. Dose dependence of fracture toughness for austenitic SSs. Dashed lines represent the scatter band for the fast reactor data at $350-450^{\circ} \mathrm{C}$.

75. Cyclic CGRs for irradiated non-GBE and GBE treated (a) Type 304 SSs and (b) Type 316 SSs tested in BWR NWC.

76. Constant-load CGRs versus stress intensity for non-GBE and GBE treated Type 304 and 316 SSs.

77. Fracture toughness J-R curves for non-GBE and GBE (a) Type 304 SSs and (b) Type 316 SSs.

78. Hardness measurements of non-GBE and GBE Type 304 and 316 SSs.

79. Grain morphology revealed by electron backscattered diffraction.

80. Grain size distribution (left) and CSL length fraction (right) for GBE and non-GBE Type 304 and $316 \mathrm{SSs}$

81. Transmission electron microscopy images for (a) non-GBE and (b) GBE Type 316 SSs.

82. TEM images for (a) non-GBE and (b) GBE 304 SSs. 
This page is intentionally left blank. 


\section{Tables}

1. Composition for the Halden-II irradiation materials ......................................................... 5

2. Fractions of CSL boundaries in Types 304 and 316 SSs with and without GBE processing..... 6

3. Irradiation conditions for the Halden-II CT specimens.................................................. 7

4. Halden phase II specimens and type of tests performed................................................. 15

5. Test results for Specimen GG3TA-TT of Type 304L SS weld HAZ in BWR water at $289^{\circ} \mathrm{C}$. . 16

6. Test results for the Type 304 SMA HAZ specimen at as-welded condition (85-7B, $0.75 \mathrm{dpa})$

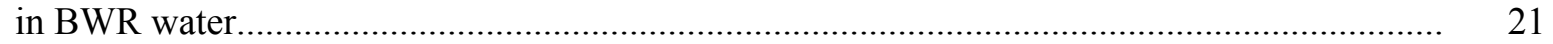

7. Test results for a thermally treated 304 SMA HAZ specimen irradiated to 2 dpa (85-2ATT)... 25

8. Test results for a Type 304 specimen sensitized at $600^{\circ} \mathrm{C}$ for $10.5 \mathrm{~h}(85-1 \mathrm{TT}, 0.75 \mathrm{dpa})$ in BWR water

9. Test results for a Type 304 specimen sensitized at $600^{\circ} \mathrm{C}$ for $24 \mathrm{~h}(85-5 \mathrm{~A} 1 \mathrm{TT}, 0.75 \mathrm{dpa})$ in BWR water.

10. Test results for the base heat of Type 304 specimen (IT304, $\approx 2 \mathrm{dpa}$ ) in BWR water.

11. Test results for the GBE-treated Type 304 specimen (GB304-01, $\approx 2$ dpa) in BWR water........

12. Test results for the base heat of Type 316 specimen (IT316-01, $\approx 2 \mathrm{dpa}$ ) in BWR water.

13. Test results for the GBE-treated Type 316 specimen (GB316-01, $\approx 2$ dpa) in BWR water.

14. Composition of austenitic stainless steels ( $\mathrm{wt} \%$ ) 
This page is intentionally left blank. 


\section{Executive Summary}

Stress corrosion cracking (SCC) is an important degradation mechanism for austenitic stainless steels (SSs) in high-temperature aqueous environments. Premature failures resulting from SCC are commonly found in thermally sensitized austenitic SSs under corrosive environments. In light water reactors (LWRs), reactor core internal components are exposed to high-temperature coolant and also subjected to high-energy irradiation by fission neutrons. The exposure to fast neutron irradiation can further increase the susceptibility of SSs to SCC by elevating the corrosion potential of the reactor coolant and by introducing new embrittlement mechanisms through radiation damage. Various nonsensitized austenitic SSs and nickel alloys have been found to be prone to intergranular cracking after extended irradiation exposure. The elevated susceptibility of irradiated materials to SCC, commonly termed irradiation-assisted stress corrosion cracking (IASCC), has become an increasingly important issue in recent years as nuclear power plants continue to age and irradiation dose increases. A comprehensive understanding of the degradation mechanism of IASCC is important for determining the structural integrity of reactor internal components and the safety and economy of aging nuclear power plants.

Post-irradiation tests of crack growth and fracture toughness have been performed on various austenitic SSs to provide data and technical support for addressing age-related degradation of reactor-core internal structures and components. In the present study, crack growth rate (CGR) tests were conducted in simulated boiling water reactor (BWR) environments on $1 / 4$ inch thick compact tension (1/4T-CT) specimens. Heat-affected-zone (HAZ) materials sectioned from Type 304L submerged arc (SA) and Type 304 shielded metal arc (SMA) welds, sensitized Type 304 SSs, and Type 304 and 316 SSs with and without grain boundary engineering (GBE) treatment were included in the study. The specimens were irradiated in the Halden reactor to 0.75 and $\approx 2$ dpa. The loading condition in all irradiated constant-load CGR tests was validated by the size criterion specified in American Society for Testing and Materials (ASTM) standard E399 using irradiated yield stress. Based on cyclic and constant-load CGR results, IASCC susceptibility was evaluated for the tested materials as a function of neutron dose, processing conditions, and water chemistry. Fracture toughness tests were also carried out in the BWR environment after the CGR tests. These latest results were combined with previous results from Halden-I and -II irradiations to analyze the effects of neutron dose, water chemistry, alloy compositions, and welding and processing conditions on IASCC. The effect of neutron irradiation on the fracture toughness of austenitic SSs was also evaluated at dose levels relevant to BWR internals. The main findings for this analysis follow.

\section{Effect of welding process}

The post-irradiation tests demonstrated that the cyclic CGRs increase significantly with increases in neutron irradiation dose for all HAZ specimens regardless of weld type or post-weld processing. The constant-load CGRs for as-welded SA and SMA HAZ specimens are approximately one order of magnitude greater than the disposition curve in NUREG-0313 for sensitized SSs in water with $8 \mathrm{ppm}$ dissolved oxygen (DO). No significant difference was present between as-welded and thermally treated HAZ materials with SA and SMA welds. The effect of low-temperature sensitization also appears to be insignificant for the IASCC susceptibility of SA and SMA weld HAZ materials.

\section{Effect of sensitization}

Type $304 \mathrm{SS}$ specimens were thermally sensitized at $600^{\circ} \mathrm{C}$ for $10.5 \mathrm{~h}$ and $24 \mathrm{~h}$ to investigate the effect of degree of sensitization on IASCC. The specimens sensitized at the two conditions exhibited similar cracking behavior under both cyclic and constant-load test conditions. Therefore, it appears that 
the degree of sensitization does not play a significant role in the cracking susceptibility of irradiated materials. Irradiation effects appear to be the dominating factor for IASCC behavior.

\section{Effect of material type and composition}

The influence of material type and material chemistry on IASCC behavior was studied by analysis of earlier CGR and slow strain rate test (SSRT) results. For the CGR tests, cyclic and constant-load CGRs of three austenitic SSs were compared at three dose levels in normal water chemistry (NWC) and hydrogen water chemistry (HWC). Within the scatter of the data, IASCC susceptibility appears to be insensitive to the material type in NWC. In HWC for dose levels up to $3 \mathrm{dpa}$, any effect of materials type is unclear due to the low CGRs observed in the low potential environment for all material types. For SSRT tests, the fraction of intergranular cracking was used to characterize the IASCC susceptibility of different alloys. The SSRT results indicate that minor alloying elements such as carbon, sulfur, and oxygen may play an important role in the IASCC process. Low-carbon and high-sulfur SSs were found to be prone to IASCC. Sulfur content below $0.002 \mathrm{wt} \%$ was found to be critical for IASCC resistance in austenitic SSs in high-DO BWR water. It is also reported in the literature that high silicon content has a detrimental effect on the SCC behavior of austenitic SSs. However, data are limited and it is unclear at present if silicon segregation resulting from neutron irradiation does elevate the cracking susceptibility.

\section{Effect of water chemistry}

Stress corrosion cracking is a strong function of corrosion potential. It has been repeatedly demonstrated that a low corrosion potential can effectively mitigate IASCC. Both cyclic and constantload CGR results have shown at least one order of magnitude reduction in CGR for HWC compared with NWC. However, a few tests conducted within the high-K (stress intensity factor) range showed that the beneficial effect of HWC is absent in some high-dose specimens ( $>3 \mathrm{dpa}$ ). This anomalous cracking behavior in HWC has often been disregarded in the literature because the loading conditions typically do not meet proposed size criteria for irradiated materials. However, the insensitiveness to low corrosion potential demonstrated by some high-dose specimens should not be ignored solely based on the violation of the proposed size criteria whose technical basis has not been adequately justified. Tests conducted under K-constraint conditions that do meet standard validity criteria have demonstrated that the HWC beneficial effect is lost with Type 304L SS at doses as low as $3 \mathrm{dpa}$. Since the dose dependence of the HWC effect is poorly understood, additional data are needed for doses higher than $3 \mathrm{dpa}$.

\section{Effect of neutron dose}

Halden-I crack growth results in NWC at three doses were used to illustrate the dose dependence of IASCC behavior. Environmental enhancement observed in the cyclic CGR tests increased continuously with dose. The constant-load CGRs, however, rose sharply above $0.45 \mathrm{dpa}$ and saturated in the high-dose region. The constant-load CGRs for the three SSs examined were approximately a factor of six higher than the NUREG-0313 curve between 1.35 and $3 \mathrm{dpa}$. The fracture toughness of austenitic SSs also decreased rapidly with neutron dose. The threshold dose for a sharp decrease in fracture toughness was about $0.3 \mathrm{dpa}$. Above $5 \mathrm{dpa}$, a slower reduction in fracture toughness with increasing dose is expected for austenitic SSs.

\section{Effect of grain boundary engineering}

Crack growth tests were also performed on GBE and non-GBE Type 304 and 316 SSs in NWC. The GBE treatments increased the fraction of coincident-site-lattice (CSL) boundaries to approximately $60 \%$ in these materials. However, the beneficial effect on IASCC resistance was not readily revealed. Further examination of the unirradiated materials showed large grain size and precipitation microstructure for both GBE Type 304 and 316 SSs. The ineffectiveness of GBE treatment suggests that the beneficial 
effect provided by a high fraction of CSL boundaries may be overwhelmed by detrimental effects introduced by brittle precipitates or large grain size. 
This page is intentionally left blank. 


\section{Acknowledgments}

The authors would like to thank T. M. Karlsen, OECD Halden Reactor Project, Halden, Norway, for specimen irradiations in the Halden reactor; D. O. Pushis for specimen retrieval; and L. A. Knoblich, E. E. Gruber, E. J. Listwan, W. K. Soppet, D. L. Rink, and R. Clark, for their contributions to the experimental effort. The authors would also like to thank Dr. Yong Yang and Prof. Todd Allen for their contributions to microstructural examination. The authors are also grateful to Dr. R. Tregoning for reviewing the manuscript and for many helpful comments. Further more, the authors are thankful to Drs. B. Alexandreanu, K. Natesan, W. H. Cullen, Jr., S. Crane, and A. S. Rao for many discussions. This work is sponsored by the Office of Nuclear Regulatory Research, U.S. Nuclear Regulatory Commission, under Job Code N-6519; Program Manager: Appajosula S. Rao. 
This page is intentionally left blank. 


\section{Acronyms and Abbreviations}

$\begin{array}{ll}\text { ASTM } & \text { American Society for Testing and Materials } \\ \text { BWR } & \text { Boiling Water Reactor } \\ \text { CGR } & \text { Crack Growth Rate } \\ \text { CSL } & \text { Coincident Site Lattice } \\ \text { CT } & \text { Compact Tension } \\ \text { DCPD } & \text { Direct Current Potential Drop } \\ \text { DO } & \text { Dissolved Oxygen } \\ \text { dpa } & \text { Displacements per Atom } \\ \text { EBSD } & \text { Electron Backscattered Diffraction } \\ \text { ECP } & \text { Electrochemical Potential } \\ \text { GBE } & \text { Grain Boundary Engineered } \\ \text { GG } & \text { Grand Gulf } \\ \text { HAZ } & \text { Heat Affected Zone } \\ \text { HWC } & \text { Hydrogen Water Chemistry } \\ \text { IASCC } & \text { Irradiation-Assisted Stress Corrosion Cracking } \\ \text { IG } & \text { Intergranular } \\ \text { IML } & \text { Irradiated Materials Laboratory } \\ \text { LWR } & \text { Light Water Reactor } \\ \text { NWC } & \text { Normal Water Chemistry } \\ \text { PWR } & \text { Pressurized Water Reactor } \\ \text { RIS } & \text { Radiation-Induced Segregation } \\ \text { SA } & \text { Submerged Arc } \\ \text { SCC } & \text { Stress Corrosion Cracking } \\ \text { SHE } & \text { Standard Hydrogen Electrode } \\ \text { SMA } & \text { Shielded Metal Arc } \\ \text { SS } & \text { Stainless Steel } \\ \text { SSRT } & \text { Slow Strain Rate Tensile } \\ \text { TG } & \text { Transgranular } \\ \text { TEM } & \text { Transmission Electron Microscopy } \\ & \end{array}$


This page is intentionally left blank. 


\section{Introduction}

Stress corrosion cracking (SCC) is a major degradation mechanism for austenitic stainless steels (SSs) in high-temperature aqueous environments. Premature failures resulting from SCC are commonly found in thermally sensitized austenitic SSs under corrosive environments. ${ }^{1,2}$ In light water reactors (LWRs), reactor core internal components are not only exposed to high-temperature coolant but also subjected to high-energy irradiation by fission neutrons. The exposure to fast neutron irradiation can further increase the susceptibility of SSs to SCC by elevating the corrosion potential of the reactor coolant and by introducing new embrittlement mechanisms through radiation damage. Various nonsensitized austenitic SSs and nickel alloys have been found to be prone to intergranular (IG) cracking after extended neutron exposure. Service failures have been seen in the core shroud, jet pump assembly, top guide, and core plate in boiling water reactors (BWRs). ${ }^{3-9}$ Failures of baffle former bolts have also been observed in pressurized water reactors (PWRs). ${ }^{10}$ The elevated susceptibility to SCC in irradiated materials, commonly referred to as irradiation-assisted stress corrosion cracking (IASCC), is a complex phenomenon that involves simultaneous actions of irradiation, stress, and corrosion. In recent years, as nuclear power plants have aged and irradiation dose has increased, IASCC has become an increasingly important issue. A comprehensive understanding of IASCC is important for determining the structural integrity of reactor internal components and the safety and economy of aging nuclear power plants.

Neutron irradiation affects material microstructure, microchemistry, and local water chemistry significantly. Point defects resulting from ballistic collisions between energetic particles and lattice atoms are the basis of radiation damage. At representative LWR operating temperatures, faulted dislocation loops, network dislocations, and, on occasion, voids can form in irradiated austenitic SSs. ${ }^{11-13}$ These microstructural changes are also accompanied by local microchemistry change during irradiation. Through the inverse Kirkendal effect, solute redistribution can occur around point defect sinks. ${ }^{14}$ Radiation-induced segregation (RIS) of alloy elements can, therefore, be seen in irradiated SSs at LWR coolant temperatures. ${ }^{15}$ Neutron irradiation has a strong effect on water chemistry by radiolysis as well. Water decomposes into oxidant species under ionizing irradiation and thus elevates corrosion potential. ${ }^{16}$ Because of the unstable nature of radiolytic products, the radiolysis effect on water chemistry is short lived and depends on neutron flux rather than fluence.

All irradiation effects on microstructure, microchemistry, and water chemistry contribute to IASCC. ${ }^{16,17}$ However, the occurrence of IG cracking in post-irradiation tests indicates that "persistent" irradiation effects on microstructure and microchemistry are the root cause of the elevated cracking susceptibility. ${ }^{18}$ For this reason, IASCC susceptibility depends on the accumulated irradiation dose, i.e., neutron fluence. A characteristic rise in IASCC susceptibility is indeed observed in post-irradiation tests above a "threshold" neutron fluence, as shown in Fig. 1 for commercial and high-purity heats. 19,20 Because of the complexity of the IASCC dependence on material and environmental variables, the threshold dose for IASCC varies with different test conditions. The proposed threshold is $\approx 5 \times 10^{20} \mathrm{n} / \mathrm{cm}^{2}(\mathrm{E}>1 \mathrm{MeV})^{*}(\approx 0.75 \mathrm{dpa})$ for BWR environments ${ }^{21,22}$ and approximately one order of magnitude higher for PWRs. ${ }^{23}$ Some studies have shown that IASCC could occur at a dose as low as $\approx 2 \times 10^{20} \mathrm{n} / \mathrm{cm}^{2}(\approx 0.3 \mathrm{dpa})$ for high-purity heats tested in water with high dissolved oxygen (DO) concentrations. $^{24}$ A better understanding of the onset of IASCC is of great technical importance. Meanwhile, the dose dependence of IASCC susceptibility and fracture behavior is also a central topic for issues related to aging reactor internal components.

\footnotetext{
*All references to fluence levels are calculated for fast neutron $\mathrm{E} \geq 1 \mathrm{MeV}$.
} 


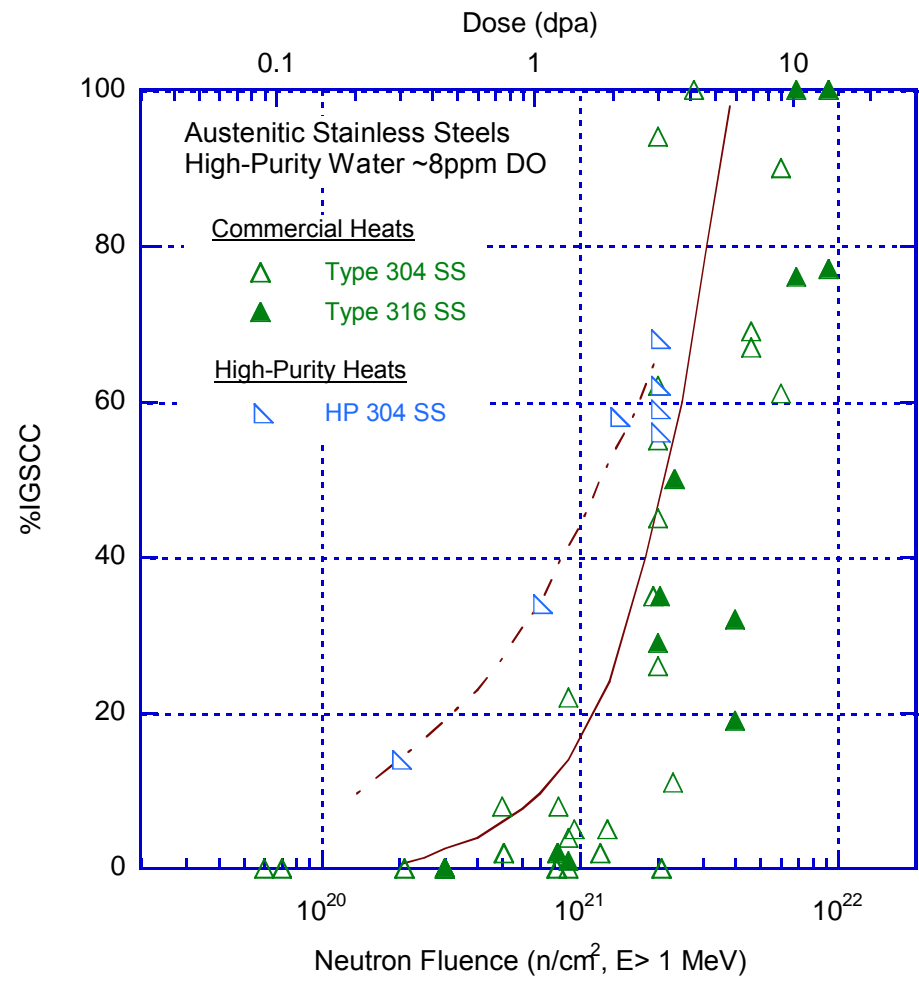

Figure 1. Susceptibility of irradiated austenitic SSs to intergranular SCC as a function of fluence in high-DO water. Data from slow-strain-rate tensile tests. ${ }^{21,} 24-26$

The IASCC susceptibility is a complex function of environmental, material, and testing variables. Because SCC susceptibility depends strongly on the corrosion potential between -100 and $0 \mathrm{mV}$ with respect to a standard hydrogen electrode (SHE), ${ }^{27}$ a low potential in BWR hydrogen water chemistry (HWC) or PWR primary water chemistry is considered to be beneficial. The threshold fluence for IASCC is, therefore, higher under low potential conditions. An effective way to mitigate SCC is to control the electrochemical corrosion potential (ECP) in BWRs. ${ }^{28,29}$ However, low corrosion potential does not provide complete immunity to IASCC. Intergranular SCC has also been observed in coldworked, irradiated SS baffle bolts in PWRs. ${ }^{30,31}$ In the present study, the cracking and fracture behavior of austenitic SSs under different water chemistries have been evaluated for different dose levels.

Early mechanistic studies of IASCC focused mainly on the depletion of $\mathrm{Cr}$ at grain boundaries and its influence on the grain boundary oxidation. ${ }^{32-34}$ Radiation-induced segregation was considered as the main reason for the sharp $\mathrm{Cr}$ depletion at grain boundaries. It is believed that the absence of protective oxide layers stimulates cracking along grain boundaries in the IASCC process. More recently, the roles of impurity elements such as $\mathrm{Si}, \mathrm{P}$, and $\mathrm{S}$ on IASCC susceptibility have also been investigated. 16,27 Although redistribution of impurities to grain boundaries due to RIS clearly does occur, no obvious correlations have yet been found between the original concentration of impurities in the bulk material and IASCC susceptibility. Recent studies on IASCC susceptibility have also attributed a greater role to radiation hardening and the development of localized deformation modes. ${ }^{35}$ The localized plastic deformation induced by irradiation contributes to the rupture of the oxide film near the grain boundary and, therefore, is a critical factor for IASCC susceptibility. ${ }^{36}$ Based on the progress in the mechanistic understanding of IASCC, various engineering methods have been proposed to mitigate the effect of IASCC on LWR core internal components. In addition, because of the predominately IG nature of IASCC, considerable attention has been paid to the role of grain boundary properties. It is believed that 
coincident site lattice (CSL) grain boundaries with low $\Sigma$ numbers* $(\leq 29)$ are more resistant to IG cracking. ${ }^{37-41}$ Grain boundary engineering (GBE), a thermomechanical treatment that systematically increases the population of low $\Sigma$ CSL grain boundaries, is considered as another potential approach to improve a material's resistance to IASCC..$^{42-45}$

This report summarizes the test results for the last group of Halden-II compact tension (CT) specimens. The IASCC susceptibility of austenitic SSs and weld heat-affected-zone (HAZ) materials was evaluated by crack growth rate (CGR) tests in simulated BWR environments. Post-irradiation CGR and J-R fracture toughness tests were performed to provide data and technical support for helping the NRC address issues related to aging degradation of reactor core internal structures and components. The fracture and cracking behavior of submerged-arc (SA) and shielded-metal-arc (SMA) HAZ materials, thermally sensitized SSs, and grain-boundary-treated SSs were investigated at several dose levels. These latest results were combined with previous results from Halden-I and II irradiations to analyze the effects of neutron dose, water chemistry, alloy compositions, and welding and processing conditions on IASCC. The effect of neutron irradiation on the fracture toughness of austenitic SSs was also evaluated at dose levels relevant to BWR internals.

\footnotetext{
${ }^{*} \Sigma$ is the reciprocal of the density of coincident sites. For example, $\Sigma$ of 17 means that one in every 17 sites in one grain coincides with a site from the neighboring grain, and the density of coincident sites is $1 / 17$.
} 
This page is intentionally left blank. 


\section{Experimental}

\subsection{Compact Tension Specimens and Materials}

Crack growth rate and J-R fracture toughness tests were conducted on 1/4T-CT specimens. Figure 2 shows a schematic of a 1/4T-CT specimen used in the present study. Besides two loading pin holes on a normal CT specimen, four additional holes were added to the specimen design to install electrical leads for crack length measurement using the potential drop method. The two through holes in the back of the specimen are designed for current leads, while the two inclined holes across the machine notch are for potential leads. Side grooves were machined for each specimen to ensure in-plane crack propagation during testing.

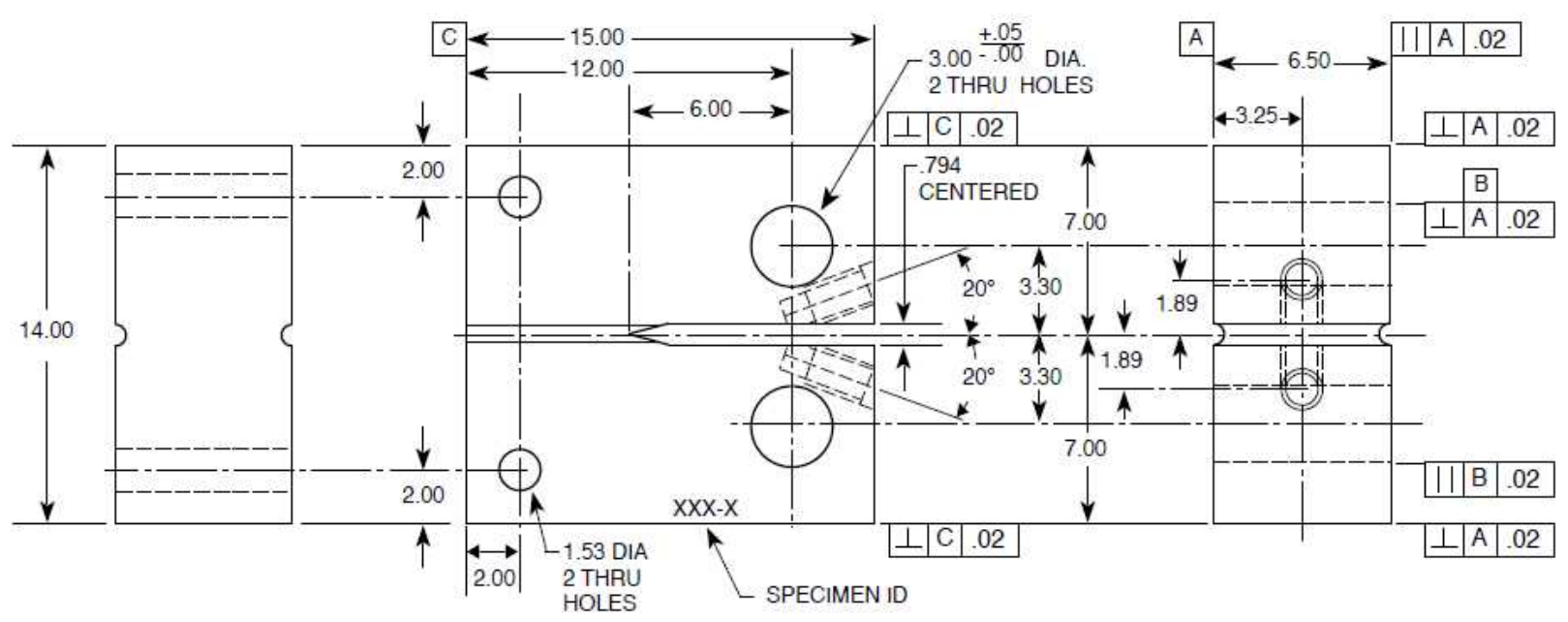

Figure 2. Configuration of compact-tension specimen used in this study (dimensions in $\mathrm{mm}$ ).

Materials sectioned from the HAZ of an SA weld and SMA weld, sensitized 304 SSs, a cast SS, and GBE-treated Type 304 and 316 SSs are included in this study. Table 1 provides the chemical composition of these alloys.

Table 1. Composition for the Halden-II irradiation materials

\begin{tabular}{|c|c|c|c|c|c|c|c|c|c|c|c|c|}
\hline Steel Type & Material ID & Descript & $\mathrm{Ni}$ & $\mathrm{Si}$ & $\mathrm{P}$ & $\mathrm{S}$ & $\mathrm{Mn}$ & $\mathrm{C}$ & $\mathrm{N}$ & $\mathrm{Cr}$ & Mo & $\mathrm{O}$ \\
\hline 304 & 10285 & HAZ, Sensitized & 8.45 & 0.60 & 0.015 & 0.007 & 1.90 & 0.070 & 0.084 & 18.56 & 0.51 & 0.013 \\
\hline $304 \mathrm{~L}$ & GG Top Shell & HAZ & 9.05 & 0.53 & 0.027 & 0.016 & 1.84 & 0.013 & 0.064 & 18.23 & 0.44 & 0.010 \\
\hline $304 \mathrm{~L}$ & GG Bottom Shell & HAZ & 8.95 & 0.55 & 0.023 & 0.008 & 1.80 & 0.015 & 0.067 & 18.62 & 0.31 & 0.014 \\
\hline 304 & Non-GBE $304^{\mathrm{a}}$ & Base & 8.46 & 0.40 & 0.013 & 0.014 & 1.56 & 0.065 & 0.086 & 18.32 & 0.36 & 0.010 \\
\hline 304 & GBE $304^{\mathrm{a}}$ & GBE & 8.42 & 0.46 & 0.014 & 0.002 & 1.54 & 0.065 & 0.088 & 18.38 & 0.50 & 0.006 \\
\hline 316 & Non-GBE $316^{\mathrm{a}}$ & Base & 10.30 & 0.43 & 0.013 & 0.014 & 1.53 & 0.055 & 0.054 & 16.42 & 2.19 & 0.006 \\
\hline 316 & GBE $316^{\mathrm{a}}$ & GBE & 11.12 & 0.56 & 0.010 & 0.022 & 1.80 & 0.070 & 0.056 & 16.57 & 2.28 & 0.007 \\
\hline CF-8M & 75 & Cast SS & 9.12 & 0.67 & 0.022 & 0.012 & 0.53 & 0.065 & 0.052 & 20.86 & 2.58 & - \\
\hline
\end{tabular}

${ }^{\mathrm{a}}$ Average values of two specimens.

The HAZ specimens used in this study were taken from a core-shroud weld of the cancelled Grand Gulf (GG) reactor and a laboratory-prepared weld. The GG weld was obtained from the H5 weld of the core shroud whose top and bottom shroud shells were fabricated from ASME SA240 Type 304L hot- 
rolled plates. The GG weld is a double-V butt joint SA weld with ER308L filler metal. Details of the GG weld have been given in previous NUREG reports. ${ }^{19,20}$ The laboratory-prepared weld is a SMA weld manufactured from 30-mm-thick plates of Type $304 \mathrm{SS}$ (Heat 10285). The weld has a single-V butt joint design and was produced by 31 weld passes using E308 filler rods. Fabrication details of this laboratory weld can also be found in these NUREG reports. ${ }^{19,20}$

The GG SA weld and the laboratory-prepared SMA weld were sliced into 9.5-mm thick blanks. Some blanks were thermally treated for $24 \mathrm{~h}$ at $500^{\circ} \mathrm{C}$ to simulate low-temperature sensitization. The CT specimens were cut from both as-welded and thermally treated weld blanks. All slices of the weldment were polished and etched to reveal the weld microstructure, as shown in Fig. 3. The machine notch of a CT specimen was located about $1 \mathrm{~mm}$ away from the fusion line on the HAZ side of a weldment. The crack plane is parallel to the fusion line and the expected direction of crack propagation is toward the center of the weld. Side grooves were machined for each CT specimen to ensure crack advance within the weld HAZ.

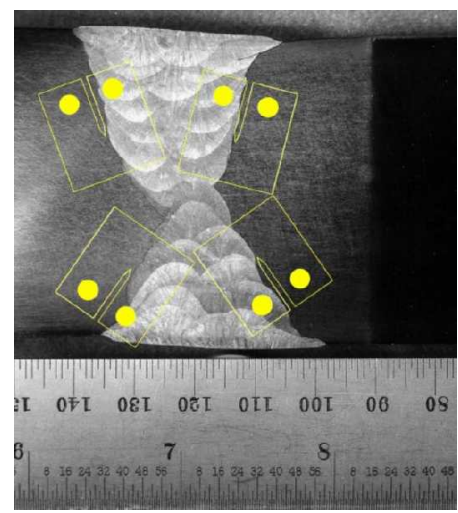

(a)

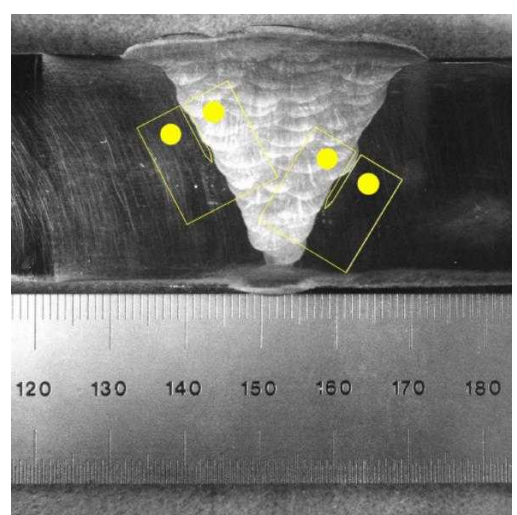

(b)

Figure 3. Weld microstructure in the (a) Grand Gulf SA weld and (b) laboratory-prepared SMA weld.

Sensitized specimens were obtained from the same Type 304 SS plate (Heat 10285) that was used for making the laboratory-prepared weld. The as-received mill-annealed Type $304 \mathrm{SS}$ was sensitized at $600^{\circ} \mathrm{C}$ for $10.5 \mathrm{~h}$ and $24 \mathrm{~h}$ to provide two different degrees of sensitization. The principal loading direction in all the sensitized CT specimens is perpendicular to the rolling direction, and the direction of crack advance is along the plate thickness (the T-S orientation).

Table 2. Fractions of CSL boundaries in Types 304 and 316 SSs with and without GBE processing.

\begin{tabular}{|c|c|c|c|c|c|c|c|c|c|c|c|c|c|c|c|c|}
\hline \multirow[b]{2}{*}{ Heat } & \multicolumn{16}{|c|}{ Boundary Type $(\Sigma)$} \\
\hline & 1 & 3 & 5 & 7 & 9 & 11 & 13 & 15 & 17 & 19 & 21 & 23 & 25 & 27 & 29 & $\leq 29$ \\
\hline non-GBE 304 & 2.1 & 28.9 & 1.0 & 0.7 & 5.4 & 0.3 & 0.5 & 0.8 & 0.4 & 0.3 & 0.4 & 0.2 & 0.4 & 2.4 & 0.2 & 44.1 \\
\hline GBE 304 & 2.2 & 52.1 & 0.4 & 0.1 & 7.3 & 0.2 & 0.2 & 0.1 & 0.1 & 0.2 & 0.2 & 0.4 & 0.2 & 3.2 & 0.3 & 67.3 \\
\hline non-GBE316 & 4.9 & 37.8 & 0.4 & 0.4 & 2.6 & 0.4 & 0.4 & 0.3 & 0.3 & 0.5 & 0.5 & 0.1 & 0.3 & 1.4 & 0.3 & 50.7 \\
\hline GBE 316 & 3.2 & 45.5 & 0.2 & 0.4 & 4.8 & 0.7 & 0.4 & 0.2 & 0.3 & 0.3 & 0.3 & 0.2 & 0.1 & 1.5 & 0.2 & 58.4 \\
\hline
\end{tabular}

Type 304 and 316 SSs with and without GBE treatment were also included in the present study. The GBE processing is a thermomechanical treatment that involves one or several iterations of strainanneal or recrystallization-anneal schedules to increase the population of low- $\Sigma$ number CSL boundaries. The chemical compositions of the GBE and non-GBE materials are given in Table 1. The fractions of low- $\Sigma$ CSL boundaries $(\leq 29)$ for non-GBE Type 304 and 316 SSs are $44 \%$ and $51 \%$, respectively, according to the Brandon criterion. The GBE processing increased the fraction of low- $\Sigma$ boundaries to 
$67 \%$ in GBE Type 304 SS and to 58\% in GBE Type 316 SS. The fractions of CSL boundaries in these materials are given in Table 2.

The CF-8M SS (Heat 75 in Table 1) was obtained from a static cast plate approximately 610 x 610 x $76 \mathrm{~mm}$. The cast SS has a duplex ferrite-austenite structure consisting of lacy ferrite morphology. Ferrite phase forms elongated islands among austenite matrix as a result of casting. ${ }^{46}$ The total ferrite content in Heat 75 is about $28 \%$. Prior to irradiation, the cast SS was aged for $10,000 \mathrm{~h}$ at $400^{\circ} \mathrm{C}$ in air.

\subsection{Irradiation}

All specimens were irradiated in helium-filled irradiation capsules in the Halden reactor, a natural circulation boiling heavy water reactor. The maximum thermal power of the Halden reactor is $25 \mathrm{MW}$, and its normal operation conditions are approximately $235^{\circ} \mathrm{C}$ and $2.8 \mathrm{MPa}(\sim 406 \mathrm{psig})$. The specimen temperature was monitored by two sets of melting alloy temperature monitors installed in each irradiation capsule. The actual neutron doses received by the specimens were determined after irradiation by activity analysis on fluence monitor wires mounted at different positions in the irradiation capsules. Iron and nickel wires were used to record the fast neutron fluence $(\mathrm{E} \geq 1 \mathrm{MeV})$, while activity analysis of $\mathrm{Al} / 1 \% \mathrm{Co}$ wires was used to estimate thermal neutron fluence $(\mathrm{E}<0.625 \mathrm{eV})$. The fast neutron fluence was used to estimate the displacement damage (dpa) on the irradiated specimens. Table 3 summarizes the irradiation conditions for the Halden-II CT specimens.

Table 3. Irradiation conditions for the Halden-II CT specimens.

\begin{tabular}{|c|c|c|c|c|c|}
\hline Material & Heat Treatment & $\begin{array}{c}\text { Number } \\
\text { of } \\
\text { Specimens }\end{array}$ & $\begin{array}{c}\text { Fast Neutron Fluence } \\
\qquad \begin{array}{c}\mathrm{MeV} \\
\left(\mathrm{x} 10^{21} \mathrm{n} / \mathrm{cm}^{2}\right)\end{array}\end{array}$ & $\begin{array}{l}\text { Displacement } \\
\text { Damage } \\
(\mathrm{dpa})\end{array}$ & $\begin{array}{c}\text { Irradiation } \\
\text { Temperature } \\
\left({ }^{\circ} \mathrm{C}\right)\end{array}$ \\
\hline \multirow{3}{*}{ GG 304L SA HAZ } & \multirow{2}{*}{ As-welded } & 2 & 0.50 & 0.75 & $\sim 290$ \\
\hline & & 2 & 1.44 & 2.15 & $290-296$ \\
\hline & $24 \mathrm{~h} @ 500^{\circ} \mathrm{C}$ & 2 & 1.63 & 2.43 & $\sim 290$ \\
\hline \multirow{4}{*}{304 SS SMA HAZ } & \multirow{2}{*}{ As-welded } & 2 & 0.50 & 0.75 & $\sim 290$ \\
\hline & & 2 & 1.44 & 2.15 & $290-296$ \\
\hline & \multirow{2}{*}{$24 \mathrm{~h} @ 500^{\circ} \mathrm{C}$} & 2 & 0.50 & 0.75 & $\sim 290$ \\
\hline & & 2 & 1.44 & 2.15 & $290-296$ \\
\hline CF-8M Cast SS & 10,000h@400C & 2 & 1.63 & 2.43 & $\sim 290$ \\
\hline \multirow{4}{*}{ Sensitized 304 SS } & \multirow{2}{*}{$10.5 \mathrm{~h} @ 600^{\circ} \mathrm{C}$} & 2 & 0.5 & 0.75 & $\sim 290$ \\
\hline & & 2 & 1.44 & 2.15 & $290-296$ \\
\hline & \multirow{2}{*}{24 h@600C } & 2 & 0.5 & 0.75 & $\sim 290$ \\
\hline & & 2 & 1.44 & 2.15 & $290-296$ \\
\hline \multirow{2}{*}{$304 \mathrm{SS}$} & non-GBE & 1 & 1.31 & 1.96 & $290-296$ \\
\hline & GBE & 1 & 1.31 & 1.96 & $290-296$ \\
\hline \multirow{2}{*}{$316 \mathrm{SS}$} & non-GBE & 1 & 1.31 & 1.96 & $290-296$ \\
\hline & GBE & 1 & 1.31 & 1.96 & $290-296$ \\
\hline
\end{tabular}

\subsection{Test Facility}

Irradiated specimens were tested in a mechanical test facility located in the Irradiated Materials Laboratory (IML) at Argonne National Laboratory. The IML is a radiological-controlled laboratory maintained at a negative pressure with respect to the surroundings and has four shielded hot cells designed for handling highly radioactive materials. The mechanical test facility consists of a loading frame, an Instron 8500+ Dynamic Materials Testing System, and a water recirculation system. The load train, actuator, furnace, autoclave, load cell, and linear variable displacement transducer of the test system are located inside a hot cell. The control console, data acquisition system, hydraulic pump, and water recirculation loop are kept outside the hot cell for the convenience of operation. Figure 4 is a schematic 
of the loading frame used in the present study. A 22-kN load cell is installed on the top of the pull rod. A 1-liter SS autoclave is installed inside the furnace to provide the simulated BWR coolant environment. The furnace is mounted on a pneumatic cylinder and can be raised to enclose the autoclave with the load cage during tests.

The hydraulic actuator is located on top of the load frame, with the test train components suspended beneath it. The load cage consists of the cover plate and a 12.7-mm-thick bottom plate separated by four compression rods. The lower two-piece clevis assembly is fastened to the bottom plate of the cage with the two sections connected by an Zircaloy pin oxidized at $500^{\circ} \mathrm{C}$ for $24 \mathrm{~h}$. The gap between the two pieces of clevis is electrically insulated by use of mica washers. The top clevis assembly is connected to the pull rod and is also insulated with the same types of Zircaloy pin and mica washers. The CT specimen is mounted in the clevises with 17-4 PH SS pins. Platinum wires are used for DC potential drop measurements during CGR and J-R tests. Two platinum wires attached to SS split pins are inserted into the through holes on the 1/4T-CT specimens (Fig. 2) to be used as current leads. Potential leads are two platinum wires attached to the SS pins that are threaded into the inclined holes at the machine notch.

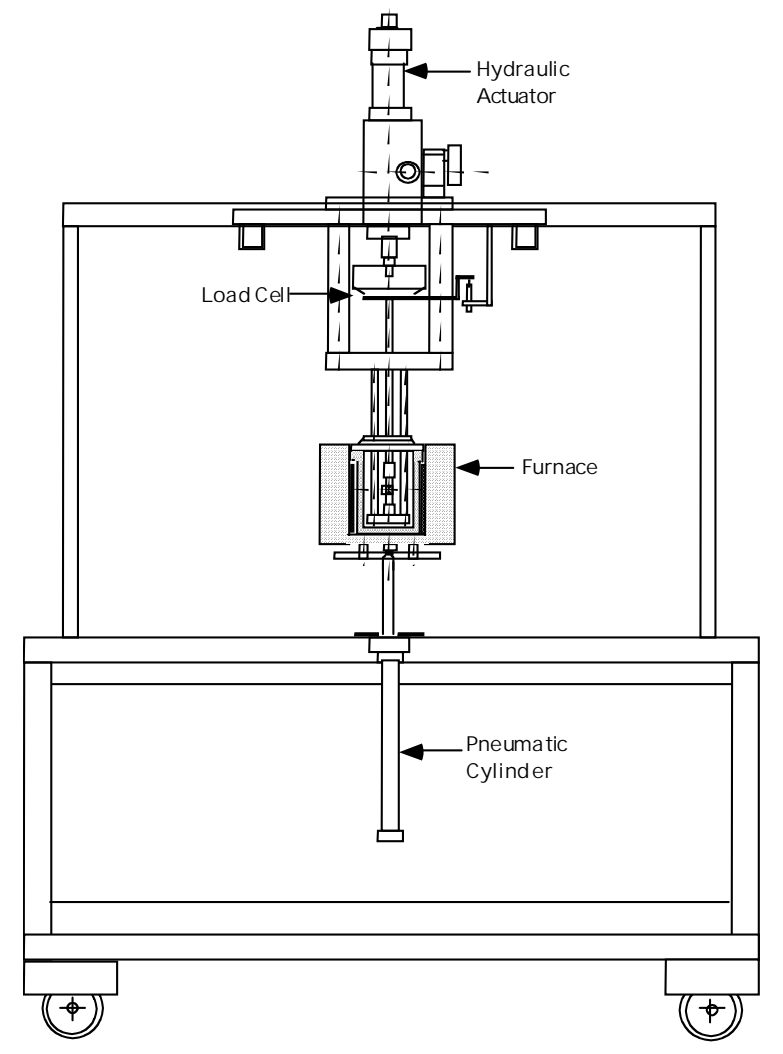

Figure 4. Mechanical test system for conducting CGR and J-R tests on radioactive specimens.

The water recirculation system that provides simulated BWR water is located outside the hot cell. The recirculation system consists of a 135-liter water retention tank, a high pressure pump, two regenerative heat exchangers, an autoclave and preheater, an ECP cell and preheater, a Mity Mite ${ }^{\mathrm{TM}}$ backpressure regulator, an ion-exchange cartridge, two 0.2-micron filters, a demineralizer resin bed, a pressure transducer, $\mathrm{pH}$ and conductivity sensors, and numerous pressure relief valves. A schematic diagram of the water recirculation system is given in Fig. 5. 
The simulated BWR environment in this study consisted of high-purity deionized water with either 250-700 ppb DO, corresponding to normal water chemistry (NWC) BWR water or $<30 \mathrm{ppb}$ DO, corresponding to HWC BWR water. The ECPs for SS are in the range of 160 to $240 \mathrm{mV}$ (vs. SHE) in NWC and -200 to $-500 \mathrm{mV}$ (vs. SHE) in HWC. The deionized water is prepared by passing purified water through a set of filters that comprise a carbon filter, an Organex-Q filter, two ion exchangers, and a $0.2-\mathrm{mm}(8-\mathrm{mil})$ capsule filter. The DO level in water is established by maintaining a cover gas of nitrogen plus $1 \%$ oxygen above the supply tank and initially bubbling the gas mixture through the deionized water. The ECP of a Pt electrode and an SS rod (1/8" in diameter) located at the exit of the autoclave was monitored continuously during the test, and water samples were taken periodically to measure $\mathrm{pH}$, resistivity, and $\mathrm{DO}$ concentration. The DO level was measured in the in-cell facility by the colorimetric technique using CHEMets sampling ampoules.

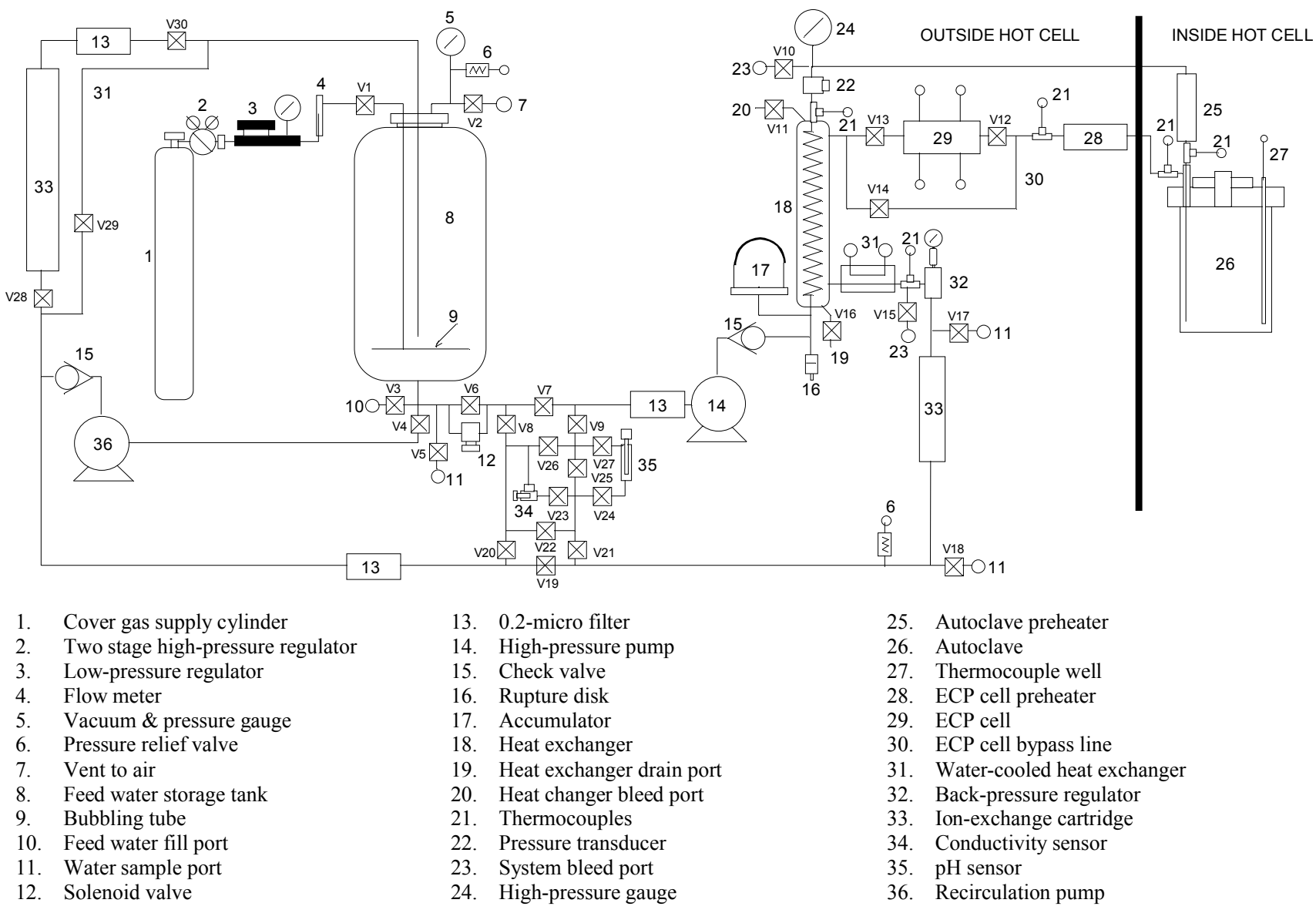

Figure 5. A schematic diagram of the water recirculation system.

All tests in the simulated BWR environment were started in high-purity water that contained 250500 ppb DO (NWC). A gas mixture of $1 \% \mathrm{O}_{2}$ balanced with $\mathrm{N}_{2}$ was normally used to achieve the required DO level for NWC in the feed water. In some tests, after the initial CGR test in NWC, the DO level of the feed water was decreased to $<30 \mathrm{ppb}$ by switching to a $\mathrm{N}_{2}+4 \% \mathrm{H}_{2}$ gas mixture for cover gas. Because of the low water flow rates, it can take several days for the environmental conditions to be stabilized for the in-cell tests. In general, the changes in ECP were slower in the SS sample than in the Pt electrode. 


\subsection{Test Procedures}

\subsubsection{Crack Growth Rate Test}

The CGR tests were performed in accordance with the American Society for Testing and Materials (ASTM) E-647, "Standard Test Method for Measurement of Fatigue Crack Growth Rates," and ASTM E1681, "Standard Test Method for Determining a Threshold Stress Intensity Factor for EnvironmentAssisted Cracking of Metallic Materials under Constant Load." All CGR tests in the present study were performed on 1/4T-CT specimens whose dimensions are given in Fig. 2. With the DC potential drop (DCPD) method, crack extension was monitored throughout a CGR test while the sample was under cyclic or constant loading.

A CGR test began with a fatigue loading stage in the simulated BWR environment with load ratio (R) around $0.2-0.3$, frequency of $1-5 \mathrm{~Hz}$, and maximum stress intensity factor $\left(\mathrm{K}_{\max }\right)$ between 10 and $16 \mathrm{MPa} \mathrm{m}{ }^{1 / 2}$. The objective of this test period is to generate a sharp fatigue crack at the machine notch and to extend the crack front beyond the damaged region immediately next to the machine notch. After an initial crack advance of several hundred micrometers, a prescribed loading sequence was followed to introduce environmentally enhanced cracking. To facilitate the transition of a transgranular (TG) fatigue crack to an IG stress corrosion crack, a series of test periods was implemented with a slow/fast sawtooth waveform at a constant $\mathrm{K}_{\max }$. During these test periods, $\mathrm{R}$ was increased incrementally to 0.7 with increasing rise times up to $1000 \mathrm{~s}$. Once the environmentally enhanced cracking was established, the test condition was changed to a constant load with or without periodic unloading to $R=0.7$ in every 1 or $2 \mathrm{~h}$. Crack growth rates $(\mathrm{m} / \mathrm{s})$ were measured and reported for each test stage. With the increase of the crack length, the load was gradually reduced to maintain a constant $\mathrm{K}$ throughout each stage during the constant load test.

The stress intensity factor $K$ for a CT specimen was calculated as follows:

$$
\mathrm{K}=\frac{\mathrm{P}}{\left(\mathrm{BB}_{\mathrm{N}} \mathrm{W}\right)^{1 / 2}} \cdot \frac{\left(2+\frac{\mathrm{a}}{\mathrm{W}}\right)}{\left(1-\frac{\mathrm{a}}{\mathrm{W}}\right)^{3 / 2}} \cdot \mathrm{f}\left(\frac{\mathrm{a}}{\mathrm{W}}\right)
$$

where $P$ is applied load; $B$ is the specimen thickness; $B_{N}$ is the net specimen thickness (or distance between the roots of the side grooves); $a$ is crack length; and $W$ is specimen width (measured from the load line to the back edge of the specimen). The geometry factor for a CT specimen is:

$$
f\left(\frac{a}{W}\right)=0.886+4.64\left(\frac{a}{W}\right)-13.32\left(\frac{a}{w}\right)^{2}+14.72\left(\frac{a}{W}\right)^{3}-5.60\left(\frac{a}{W}\right)^{4}
$$

During a test in water, the friction between the autoclave seal and the pull rod exerted a force of about 20 to $30 \mathrm{lb}(89-133 \mathrm{~N})$ on the pull rod. This fraction load was measured for each test to correct the real load acting on a specimen. The applied $\mathrm{K}$ and the load ratio were determined by subtracting the frictional load from the measured maximum load and adding frictional load to the measured minimum load. The most significant effect of this correction is on the waveform for the cyclic tests. For triangular or sawtooth waveforms generated by the test machine, the actual loading waveforms applied on a specimen are trapezoidal because the top and bottom parts of the loading or unloading cycles are truncated to overcome the friction at the sealing surface. For example, for a test intended to be conducted 
at $\mathrm{R}=0.7$ and a sawtooth waveform with 300 -s rise time and 12-s return time, the actual loading waveform was trapezoidal with 112-s hold time at minimum load, 188-s rise time, 6-s hold time at maximum load, and 6-s return time.

After each CGR test, optical images were taken of the fracture surface, and the final crack length was measured to compare with the DCPD result. Because of unbroken ligaments or an uneven crack front, crack extension is usually underestimated by the DCPD method. Thus, the crack length obtained by the DCPD method for each test period was scaled proportionally with the optical measurement of the final crack length. The corrected plot for crack length vs. time was used to determine the crack growth rate for each test period. For cyclic loading, only the rise time was used to determine the crack growth rate.

In linear elastic fracture mechanics, the stress intensity factor is a single parameter that characterizes the stress-strain field at a crack tip. For K-controlled fracture, the plastic zone ahead of the crack tip must be embedded within an elastic singularity zone. To ensure a K-controlled fracture so that the test results are independent of sample size, the following sample/crack size requirement is adopted,

$$
\mathrm{B}_{\text {eff }} \text { and }(\mathrm{W}-\mathrm{a}) \geq 2.5\left(\mathrm{~K} / \sigma_{\mathrm{y}}\right)^{2}
$$

where $K$ is the applied stress intensity factor, $\sigma_{\mathrm{y}}$ is the yield stress of the material, $a$ is crack length, $W$ is specimen width, and the $B_{\text {eff }}$ is the specimen effective thickness, defined as $\left(\mathrm{B} \cdot \mathrm{B}_{\mathrm{N}}\right)^{0.5}$. Joyce and Tregoning 47 have demonstrated that this size criterion is a very conservative requirement to ensure a small-scale yielding condition. For materials with high strain-hardening capacity, i.e., $\left(\sigma_{\mathrm{u}} / \sigma_{\mathrm{y}}\right) \geq 1.3$ (e.g., nonirradiated SSs), the flow stress defined as $\sigma_{\mathrm{f}}=\left(\sigma_{\mathrm{u}}+\sigma_{\mathrm{y}}\right) / 2$ rather than the yield stress can be used to scale the plastic zone size. Unless otherwise noted, all CGRs reported in this study were obtained under conditions where Eq. (3) is satisfied.

\subsubsection{Model for Crack Growth Rate Test Analysis}

To reveal the environmental effects on cracking, a superposition model ${ }^{48}$ was used to analyze the cyclic CGR test results. The model assumes that a cyclic CGR in environment $\left(\dot{a}_{\text {env }}\right)$ includes three components representing mechanical fatigue in air $\left(\dot{\mathrm{a}}_{\text {air }}\right)$, corrosion fatigue in the environment $\left(\dot{\mathrm{a}}_{\mathrm{cf}}\right)$, and stress corrosion cracking under constant load $\left(\dot{a}_{\text {scc }}\right)$, i.e.

$$
\dot{\mathrm{a}}_{\mathrm{env}}=\dot{\mathrm{a}}_{\mathrm{air}}+\dot{\mathrm{a}}_{\mathrm{cf}}+\dot{\mathrm{a}}_{\mathrm{scc}}
$$

The mechanical fatigue growth rate, $\dot{a}_{\text {air }}(\mathrm{m} / \mathrm{s})$, can be determined from a correlation developed by James and Jones: 49

$$
\dot{\mathrm{a}}_{\text {air }}=\mathrm{C}_{\mathrm{SS}}(\mathrm{T}) \cdot \mathrm{S}(\mathrm{R}) \cdot \Delta \mathrm{K}^{3.3} / \mathrm{t}_{\mathrm{r}}
$$

where $\Delta \mathrm{K}=\mathrm{K}_{\max }-\mathrm{K}_{\min }$ in MPa m${ }^{1 / 2}$, and $t_{r}$ is the rise time (s) of the loading waveform. Furthermore, $\mathrm{C}_{\mathrm{SS}}$ is a function of temperature only and is given by a third-order polynomial function as

$$
\mathrm{C}_{\mathrm{SS}}=1.9142 \times 10^{-12}+6.7911 \times 10^{-15} \mathrm{~T}-1.6638 \times 10^{-17} \mathrm{~T}^{2}+3.9616 \times 10^{-20} \mathrm{~T}^{3}
$$

The $S(R)$ is a piecewise function of the load ratio $(R)$ : 


$$
\begin{array}{ll}
\mathrm{S}(\mathrm{R})=1.0 & \mathrm{R}<0 \\
\mathrm{~S}(\mathrm{R})=1.0+1.8 \mathrm{R} & 0<\mathrm{R}<0.79 \\
\mathrm{~S}(\mathrm{R})=-43.35+57.97 \mathrm{R} & 0.79<\mathrm{R}<1.0
\end{array}
$$

where the load ratio $\mathrm{R}$ is defined as $\mathrm{K}_{\min } / \mathrm{K}_{\max }$. To evaluate environmental enhancement, the mechanical fatigue CGR in air was estimated for each cyclic loading condition, and was compared with the measured CGR in the environment. Under the rapid cyclic loading typically used for precracking, the crack growth is dominated by mechanical fatigue. The CGR in environment is very similar to that observed in air. Environmentally enhanced cracking is more evident under high load ratios and long rise times. Usually, significantly higher cyclic CGRs in high-purity water can be seen for irradiated SSs under load ratios greater than 0.5 and rise time longer than $30 \mathrm{~s}$.

A model developed by Shack and Kassner 48 has been used successfully to characterize the environmental effects on fatigue crack growth for nonirradiated austenitic SSs. In the absence of a significant contribution of SCC to growth rate, the CGRs in water with $\approx 0.3 \mathrm{ppm}$ DO are best represented by:

$$
\dot{\mathrm{a}}_{\text {env }}=\dot{\mathrm{a}}_{\text {air }}+4.5 \times 10^{-5}\left(\dot{\mathrm{a}}_{\text {air }}\right)^{0.5}
$$

and the CGRs in water with $\approx 8 \mathrm{ppm}$ DO is,

$$
\dot{\mathrm{a}}_{\text {env }}=\dot{\mathrm{a}}_{\text {air }}+1.5 \times 10^{-4}\left(\dot{\mathrm{a}}_{\text {air }}\right)^{0.5}
$$
Rev. 2: 50

Under SCC conditions ( $\left.\dot{\mathrm{a}}_{\mathrm{scc}}\right)$, the CGR can be represented by a correlation given in NUREG-0313,

$$
\dot{\mathrm{a}}_{\mathrm{scc}}=\mathrm{A} \cdot \mathrm{K}^{2.161}
$$

The magnitude of the constant $A$ depends on the water chemistry and composition and structure of the steel. An $A$ value of $2.1 \times 10^{-13}$ is proposed in NUREG-0313 for sensitized SS in water with 8 ppm DO. The value of constant $A$ is smaller in low-DO environments, such as HWC BWR or PWR environments. For water with $0.2 \mathrm{ppm}$ DO, the constant $A$ is taken as one-third that given in NUREG-0313. In the present study, CGRs measured under constant-loading conditions are plotted as a function of stress intensity, with the NUREG-0313 curve used as a reference. With the K-dependence given in Eq. (10) as a guideline, the SCC susceptibility was evaluated for different irradiated SSs and for different water chemistries (NWC vs. HWC).

\subsubsection{Fracture Toughness J-R Curve Tests}

For some specimens, a fracture toughness J-R test was performed at $289^{\circ} \mathrm{C}$ in NWC after the CGR test. The J-R test was conducted at a constant extension rate of $\approx 0.43 \mu \mathrm{m} / \mathrm{s}(0.017 \mathrm{mil} / \mathrm{s})$ in accordance with ASTM E-1820 for "Standard Test Method for Fracture Toughness." The test was interrupted periodically (by holding the specimen at constant extension) to measure the crack length. Prior to a DCPD measurement, the specimen was held at a constant strain for $\approx 30 \mathrm{~s}$ for stress relaxation. Since the specimen extension was monitored and controlled outside the high-temperature zone, the actual displacement of load points was determined by subtracting the extension of the load train from the measured extension. The load train displacement was determined as a function of applied load by using a specimen with high stiffness. 
The J-integral was calculated from the load $(P)$ vs. load-line displacement $(v)$ curves according to ASTM Specification E 1820. The $J$ is the sum of the elastic and plastic components, $J_{e l}$ and $J_{p l}$,

$$
\mathrm{J}=\mathrm{J}_{\mathrm{el}}+\mathrm{J}_{\mathrm{pl}}
$$

At a hold point $i$ corresponding to crack length $a_{i}$, and $v_{i}$ and $P_{i}$ on the load vs. load-line displacement curve, the elastic component $J_{e l(i)}$ is given by:

$$
\mathrm{J}_{\mathrm{el}(\mathrm{i})}=\frac{\left(\mathrm{K}_{(\mathrm{i})}\right)^{2}\left(1-\mathrm{v}^{2}\right)}{\mathrm{E}}
$$

where $v$ is Poisson's ratio, and the stress intensity $K_{(i)}$ is calculated from Eqs. 1 and 2. The plastic component $J_{p l(i)}$ is given by:

$$
\mathrm{J}_{\mathrm{pl}(\mathrm{i})}=\left[\mathrm{J}_{\mathrm{pl}(\mathrm{i}-1)}+\left(\frac{\eta_{(\mathrm{i}-1)}}{\mathrm{b}_{(\mathrm{i}-1)}}\right) \frac{\mathrm{A}_{\mathrm{pl}(\mathrm{i})}-\mathrm{A}_{\mathrm{pl}(\mathrm{i}-1)}}{\mathrm{B}_{\mathrm{N}}}\right]\left[1-\gamma_{(\mathrm{i}-1)} \frac{\mathrm{a}_{(\mathrm{i})}-\mathrm{a}_{(\mathrm{i}-1)}}{\mathrm{b}_{(\mathrm{i}-1)}}\right]
$$

where $b_{(i-1)}$ is the remaining ligament (distance from the physical crack front to the back edge of the specimen) at a point $i-1 ; A_{p l(i)}$ is the area under the load vs. load-line displacement curve; and $B_{N}$ is the net specimen thickness. In addition, $\gamma_{(i)}$ and $\eta_{(i)}$ are factors that account for the crack growth effects on $\mathrm{J}$ during the test and are expressed as:

$$
\begin{aligned}
& \eta_{(i-1)}=2.0+0.552 \frac{\mathrm{b}_{(\mathrm{i}-1)}}{\mathrm{W}} \\
& \gamma_{(\mathrm{i}-1)}=1.0+0.76 \frac{\mathrm{b}_{(\mathrm{i}-1)}}{\mathrm{W}}
\end{aligned}
$$

In Eq. (13), the quantity $A_{p l(i)}-A_{p l(i-1)}$ is the increment of plastic area under the load vs. load-line displacement curve between lines of constant plastic displacement at points $i-l$ and $i$. The quantity $J_{p l(i)}$ represents the total crack-growth-corrected plastic $J$ at point $i$ and is obtained by first incrementing the existing $J_{p l(i-1)}$ and then modifying the total accumulated result to account for the crack growth increment. Accurate evaluations of $J_{p l(i)}$ require small uniform increments in crack growth. The plastic area under the load vs. load-line displacement record is given by

$$
A_{p l(i)}=A_{p l(i-1)}+\frac{\left[P_{i}+P_{i-1}\right]\left[v_{p l(i)}-v_{p l(i-1)}\right]}{2}
$$

where the total and plastic components of the load-line displacement, $v_{(i)}$ and $v_{p l(i)}$, respectively, are expressed as

$$
\mathrm{v}_{\mathrm{pl}(\mathrm{i})}=\mathrm{v}_{(\mathrm{i})}-\mathrm{P}_{\mathrm{i}} \mathrm{C}_{\mathrm{LL}(\mathrm{i})}
$$


where $C_{L L(i)}$ is the compliance, $(\Delta v / \Delta P)_{i}$, required to give the current crack length $a_{i}$. For test methods that do not use the elastic compliance techniques, $C_{L L(i)}$ can be determined from knowledge of $a_{i} / W$, as follows:

$$
\mathrm{C}_{\mathrm{LL}(\mathrm{i})}=\frac{\left[1.62+17.80\left(\mathrm{a}_{\mathrm{i}} / \mathrm{W}\right)-4.88\left(\mathrm{a}_{\mathrm{i}} / \mathrm{W}\right)^{2}+1.27\left(\mathrm{a}_{\mathrm{i}} / \mathrm{W}\right)^{3}\right]}{\mathrm{E}^{\prime} \mathrm{B}_{\mathrm{e}}\left[1-\left(\mathrm{a}_{\mathrm{i}} / \mathrm{W}\right)^{2}\right]}
$$

where $B_{e}$ is specimen effective thickness given by $B-\left(B-B_{N}\right)^{2} / B$ and $E^{\prime}=E /\left(1-v^{2}\right)$.

After the test, the final crack size was marked by fatigue cycling in air at room temperature. The specimens were then fractured, and the fracture surface of both halves of the specimen was photographed with a telephoto lens through the hot cell window. The final crack length of each half of the fractured specimen was determined from the optical photograph by the $9 / 8$ averaging technique. In this technique, nine measurements were taken across the width of the specimen at equal intervals, the two near-surface measurements were averaged, and the resultant value was averaged with the remaining seven measurements. The crack extensions determined from the DCPD method were proportionately scaled to match the final optically measured crack length.

The experimental results from the J-R curve test were analyzed in accordance with ASTM E-1820 to obtain the fracture toughness J-R curve. The DC potential data were corrected to account for the effects of plasticity on the measured potential, since large crack-tip plasticity can increase the measured potentials due to resistivity increases without crack extension. The change in potential before crack initiation was ignored, and the remainder of the potential change was used to establish the J-R curve. The normalized potential varies linearly with load-line displacement until the onset of crack extension. For all data prior to the loss in linearity, crack extension was expressed as $a_{O}+\Delta a_{B}$, where $a_{O}$ is the initial crack length, and the crack extension $\Delta a_{B}$ is calculated from the blunting line relationship $\Delta a=J /\left(4 \sigma_{f}\right)$, where $\sigma_{f}$ is flow stress and defined as the average of yield strength $\left(\sigma_{y}\right)$ and ultimate tensile strength $\left(\sigma_{u}\right)$. The use of the blunting line given by $\Delta a=J /\left(4 \sigma_{f}\right)$ is not consistent with ASTM E 1820, which specifies a slope of two times the effective yield stress (or flow stress) for the blunting line. However, for highstrain-hardened materials, such as austenitic SSs, a slope that is four times the flow stress $\left(4 \sigma_{f}\right)$ represents the blunting line better than the slope of $2 \sigma_{f}$ defined in ASTM E 1820.51,52 In irradiated materials, irradiated yield strength $\left(\sigma_{y-i r r}\right)$ is used to replace $\sigma_{f}$. In this study, although strain hardening is low or even absent in irradiated SSs, the blunting line of $4 \sigma_{y-i r r}$ is still used to be more conservative in evaluating $\mathrm{J}$ values. 


\section{Experimental Results}

Heat-affected zone materials from Type 304 and 304L SS welds, sensitized Type 304 SS, thermally aged cast SS, and Type 304 and 316 SSs with and without GBE treatment were included in the Halden-II test matrix. Two dose levels of the irradiated specimens, $\sim 0.75 \mathrm{dpa}$ and $\sim 2 \mathrm{dpa}$, were available for testing. Table 4 summarized all specimens tested in the Halden-II study. Most J-R tests were performed in simulated BWR environments in NWC or HWC. Two J-R tests were performed in air. Test results on all nonirradiated and some irradiated specimens have been reported in previous NUREG reports. 19,20 This report summarizes the results on specimens of weld HAZ (GG3TA-TT, 85-7B and 85-2ATT), sensitized SS (85-1TT, 85-5A1TT, and 85-5A2TT), and GBE materials (IT304-01, GB304-01, IT316-01 and GB316-01).

Table 4. Halden phase II specimens and type of tests performed.

\begin{tabular}{|c|c|c|c|c|c|c|}
\hline \multirow[b]{2}{*}{ Material Type } & \multirow[b]{2}{*}{ Condition } & \multirow{2}{*}{$\begin{array}{l}\text { Dose } \\
\text { (dpa) }\end{array}$} & \multirow{2}{*}{$\begin{array}{c}\text { Specimen } \\
\text { ID }\end{array}$} & \multicolumn{2}{|c|}{ Test Performed } & \multirow{2}{*}{$\begin{array}{c}\text { Main } \\
\text { Objectives }\end{array}$} \\
\hline & & & & CGR & $\mathrm{J}-\mathrm{R}$ & \\
\hline GG 304L SA HAZ & As welded & - & GG5BA & $\sqrt{ }$ & - & \multirow{3}{*}{ Effect of SA weld } \\
\hline GG 304L SA HAZ & As welded & 0.75 & GG5TA, GG5TB & $\sqrt{ }$ & - & \\
\hline GG 304L SA HAZ & As welded & 2.15 & GG6TA, GG6TB a & $\sqrt{ }$ & $\sqrt{ }$ & \\
\hline GG 304L SA HAZ & Heat treated,24h@500C & - & GG3BA-TT & $\sqrt{ }$ & \multirow{2}{*}{$\bar{V}$} & \multirow{2}{*}{$\begin{array}{c}\text { Effect of heat } \\
\text { treatment on SA } \\
\text { weld }\end{array}$} \\
\hline GG 304L SA HAZ & Heat treated,24h@500C & 2.43 & GG3TA-TT & $\sqrt{ }$ & & \\
\hline 304 SMA HAZ & As welded & - & $85-Y A$ & $\sqrt{ }$ & - & \multirow{3}{*}{$\begin{array}{l}\text { Effect of SMA } \\
\text { Weld }\end{array}$} \\
\hline 304 SMA HAZ & As welded & 0.75 & $85-7 \mathrm{~A}, 85-7 \mathrm{~B}$ & $\sqrt{ }$ & $\sqrt{ }$ & \\
\hline 304 SMA HAZ & As welded & 2.15 & $85-\mathrm{XA}, 85-\mathrm{XB}$ & $\sqrt{ }$ & $\sqrt{ }$ & \\
\hline 304 SMA HAZ & Heat treated,24h@500C & - & $85-3 \mathrm{ATT}$ & $\sqrt{ }$ & - & \multirow{3}{*}{$\begin{array}{c}\text { Effect of heat } \\
\text { treatment on SMA } \\
\text { weld }\end{array}$} \\
\hline 304 SMA HAZ & Heat treated,24h@500 C & 0.75 & 85-1ATT & $\sqrt{ }$ & - & \\
\hline 304 SMA HAZ & Heat treated,24h@500 $\mathrm{C}$ & 2.15 & $85-2 \mathrm{ATT}$ & $\sqrt{ }$ & $\sqrt{ }$ & \\
\hline CF-8M Cast SS & Thermally aged, 10,000 h@ $400^{\circ} \mathrm{C}$ & 2.43 & 75-11TT, 75-11TM & $\sqrt{ }$ & $\sqrt{ }$ & $\begin{array}{c}\text { Effect of thermal } \\
\text { aging }\end{array}$ \\
\hline $304 \mathrm{SS}$ & Sensitized, 10.5 h@600C & 0.75 & $85-1 \mathrm{TT}$ & $\sqrt{ }$ & $\sqrt{ }$ & \multirow{4}{*}{$\begin{array}{c}\text { Effect of } \\
\text { sensitization }\end{array}$} \\
\hline $304 \mathrm{SS}$ & Sensitized,10.5h@600C & 2.15 & $85-3 \mathrm{TT}$ & $\sqrt{ }$ & $\sqrt{ }$ & \\
\hline $304 \mathrm{SS}$ & Sensitized,24h@600C & 0.75 & 85-5A1TT & $\sqrt{ }$ & - & \\
\hline $304 \mathrm{SS}$ & Sensitized,24h@600C & 2.15 & $85-5 \mathrm{~A} 2 \mathrm{TT}^{\mathrm{a}}$ & - & $\sqrt{ }$ & \\
\hline $304 \mathrm{SS}$ & Non-GBE & 1.96 & IT304-01 & $\sqrt{ }$ & $\sqrt{ }$ & \multirow{4}{*}{$\begin{array}{c}\text { Effect of GBE } \\
\text { treatment }\end{array}$} \\
\hline $304 \mathrm{SS}$ & GBE treatment & 1.96 & GB304-01 & $\sqrt{ }$ & $\sqrt{ }$ & \\
\hline $316 \mathrm{SS}$ & Non-GBE & 1.96 & IT316-01 & $\sqrt{ }$ & $\sqrt{ }$ & \\
\hline $316 \mathrm{SS}$ & GBE treatment & 1.96 & GB316-01 & $\sqrt{ }$ & $\sqrt{ }$ & \\
\hline
\end{tabular}

a J-R test was performed in air.

\subsection{Thermally Treated Type 304L SA Weld HAZ Irradiated to 2.4 dpa (GG3TA-TT)}

To simulate the effect of low-temperature sensitization, a Type 304L SA weld was thermally treated at $500^{\circ} \mathrm{C}$ for $24 \mathrm{~h}$. The specimen, GG3TA-TT, was sectioned from weld HAZ with the machine notch parallel to the fusion line. The specimen was irradiated to $\approx 2.4 \mathrm{dpa}$ at approximately $290^{\circ} \mathrm{C}$. After being exposed to the test environment for over $80 \mathrm{~h}$, fatigue precracking was started on this specimen in high-purity water with $600 \mathrm{ppb} \mathrm{DO}$ at $289^{\circ} \mathrm{C}$. A triangular waveform was applied to the specimen at a frequency of $1 \mathrm{~Hz}, \mathrm{R}$ ratio of 0.2 to 0.35 , and $\mathrm{Kmax} \approx 15 \mathrm{MPa} \mathrm{m}{ }^{1 / 2}$. Following about $120-\mu \mathrm{m}$ crack advance, the $\mathrm{R}$ ratio was increased, and a slow/fast sawtooth waveform was employed to transfer the cracking mode from transgranular to intergranular. This initial attempt to reveal environmental enhancement was unsuccessful, and the crack growth rate became negligibly low. Several cyclic loading periods with triangular waveforms were repeated with an increased $\mathrm{K}_{\max }$ to re-establish a desired crack growth. The environmental and test conditions, crack length, and CGR for each test stage are summarized in Table 5. Figure 6 is a crack-length-vs.-time plot for this test. The green line is crack 
length, and the red line is the $\mathrm{K}$ value. The cyclic CGRs obtained in this weld HAZ specimen are shown in Fig. 7.

Table 5. Test results for Specimen GG3TA-TT of Type 304L SS weld HAZ in BWR water at $289^{\circ} \mathrm{C}$.

\begin{tabular}{|c|c|c|c|c|c|c|c|c|c|c|c|c|c|c|}
\hline \multirow{2}{*}{$\begin{array}{c}\text { Test } \\
\text { Period }\end{array}$} & \multirow{2}{*}{$\begin{array}{c}\text { Test } \\
\text { Time, } \\
\text { h }\end{array}$} & \multirow{2}{*}{$\begin{array}{c}\text { Test } \\
\text { Temp., } \\
{ }^{\circ} \mathrm{C}\end{array}$} & \multicolumn{2}{|c|}{$\begin{array}{c}\text { ECP, }{ }^{\mathrm{a}} \\
\mathrm{mV}(\mathrm{SHE})\end{array}$} & \multirow{2}{*}{$\begin{array}{c}\mathrm{O}_{2} \\
\text { Conc., }{ }^{\mathrm{a}} \\
\text { ppb }\end{array}$} & \multirow{2}{*}{$\begin{array}{c}\text { R } \\
\text { Load } \\
\text { Ratio } \\
\end{array}$} & \multirow{2}{*}{$\begin{array}{c}\text { Rise } \\
\text { Time, } \\
\mathrm{s} \\
\end{array}$} & \multirow{2}{*}{$\begin{array}{c}\text { Return } \\
\text { Time, } \\
\text { s } \\
\end{array}$} & \multirow{2}{*}{$\begin{array}{c}\text { Hold } \\
\text { Time }^{\mathrm{b}} \\
\mathrm{s}\end{array}$} & \multirow{2}{*}{$\begin{array}{c}\mathrm{K}_{\max } \\
\mathrm{MPa} \mathrm{m}^{1 / 2}\end{array}$} & \multirow{2}{*}{$\begin{array}{c}\Delta \mathrm{K}, \\
\mathrm{MPa} \mathrm{m}^{1 / 2}\end{array}$} & \multirow{2}{*}{$\begin{array}{c}\text { CGR in } \\
\text { Env., } \\
\mathrm{m} / \mathrm{s}\end{array}$} & \multirow{2}{*}{$\begin{array}{c}\text { CGR in } \\
\text { Air, } \\
\text { m/s }\end{array}$} & \multirow{2}{*}{$\begin{array}{c}\text { Crack } \\
\text { Length, } \\
\text { mm }\end{array}$} \\
\hline & & & $\mathrm{Pt}$ & Steel & & & & & & & & & & \\
\hline & & & & & & & & & & & & & & 5.761 \\
\hline Pre a & 7 & 290 & 290 & 235 & 600 & 0.21 & 0.42 & 0.42 & $0.08 / 0.08$ & 15.4 & 12.2 & $1.12 \mathrm{E}-8$ & $4.31 \mathrm{E}-18$ & 5.866 \\
\hline Pre b & 9 & 289 & & & 600 & 0.35 & 0.41 & 0.41 & $0.09 / 0.09$ & 15.3 & 10.0 & 7.27E-9 & $2.68 \mathrm{E}-8$ & 5.888 \\
\hline Pre c & 22 & 289 & & & 600 & 0.49 & 19.5 & 19.5 & $5.5 / 5.5$ & 15.0 & 7.6 & negligible & $2.71 \mathrm{E}-10$ & 5.894 \\
\hline Pre d & 28 & 289 & & & 600 & 0.49 & 0.39 & 0.39 & $0.11 / 0.11$ & 15.3 & 7.8 & $3.62 \mathrm{E}-9$ & $1.45 \mathrm{E}-8$ & 5.920 \\
\hline Pre e & 49 & 289 & & & 600 & 0.43 & 8.0 & 1.6 & $2.0 / 0.4$ & 15.1 & 8.6 & negligible & $9.27 \mathrm{E}-10$ & 5.921 \\
\hline Pre $f$ & 56 & 289 & & & 600 & 0.29 & 0.84 & 0.84 & $0.16 / 0.16$ & 15.7 & 11.1 & negligible & $1.75 \mathrm{E}-8$ & 5.933 \\
\hline Pre g & 81 & 289 & & & 600 & 0.24 & 0.42 & 0.42 & $0.08 / 0.08$ & 15.6 & 12.1 & negligible & $4.34 \mathrm{E}-8$ & 5.930 \\
\hline Pre h & 123 & 289 & & & 600 & 0.23 & 0.43 & 0.43 & $0.07 / 0.07$ & 16.0 & 12.3 & negligible & $4.58 \mathrm{E}-8$ & 5.941 \\
\hline Pre i & 145 & 289 & & & 600 & 0.25 & 0.43 & 0.43 & $0.07 / 0.07$ & 17.5 & 13.2 & $5.03 \mathrm{E}-9$ & $5.77 \mathrm{E}-8$ & 5.968 \\
\hline Pre j & 152 & 289 & & & 600 & 0.25 & 0.85 & 0.85 & $0.15 / 0.15$ & 17.1 & 12.9 & $4.18 \mathrm{E}-9$ & $2.66 \mathrm{E}-8$ & 6.019 \\
\hline Pre k & 166 & 289 & & & 600 & 0.24 & 4.26 & 4.26 & $0.74 / 0.74$ & 17.1 & 12.9 & $1.01 \mathrm{E}-9$ & $5.41 \mathrm{E}-9$ & 6.042 \\
\hline Pre 1 & 170 & 289 & & & 600 & 0.24 & 0.85 & 0.85 & $0.15 / 0.15$ & 17.1 & 13.0 & $1.65 \mathrm{E}-9$ & $2.72 \mathrm{E}-8$ & 6.051 \\
\hline $1 \mathrm{a}$ & 189 & 290 & & & 600 & 0.26 & 4.24 & 0.85 & $0.76 / 0.15$ & 17.0 & 12.6 & $2.83 \mathrm{E}-10$ & $5.09 \mathrm{E}-9$ & 6.069 \\
\hline $1 b$ & 195 & 290 & & & 600 & 0.31 & 2.11 & 0.84 & $0.39 / 0.16$ & 17.7 & 12.3 & $1.39 \mathrm{E}-9$ & $9.89 \mathrm{E}-9$ & 6.084 \\
\hline $1 \mathrm{c}$ & 206 & 290 & & & 600 & 0.32 & 2.11 & 0.84 & $0.39 / 0.16$ & 18.4 & 12.5 & $9.71 \mathrm{E}-10$ & $2.68 \mathrm{E}-9$ & 6.136 \\
\hline $1 d$ & 222 & 290 & & & 600 & 0.31 & 42.3 & 10.2 & $7.7 / 1.8$ & 18.3 & 12.6 & $2.63 \mathrm{E}-10$ & $5.45 \mathrm{E}-10$ & 6.148 \\
\hline 1e & 272 & 290 & 271 & 207 & 600 & 0.30 & 254 & 10.2 & $46 / 1.8$ & 18.6 & 13.0 & $3.76 \mathrm{E}-10$ & $9.97 \mathrm{E}-11$ & 6.197 \\
\hline 2 & 291 & 290 & 270 & 203 & 600 & 0.69 & 213 & 8.5 & $78 / 3.5$ & 18.8 & 5.7 & $5.46 \mathrm{E}-10$ & $1.17 \mathrm{E}-11$ & 6.226 \\
\hline 3 & 335 & 290 & 282 & 218 & 600 & 0.69 & 711 & 8.5 & $289 / 3.5$ & 18.8 & 5.7 & $3.89 \mathrm{E}-10$ & $3.51 \mathrm{E}-12$ & 6.265 \\
\hline 4 & 391 & 290 & 284 & 223 & 600 & 0.68 & 696 & 8.4 & $304 / 3.6$ & 17.1 & 5.5 & $2.22 \mathrm{E}-10$ & $2.98 \mathrm{E}-12$ & 6.291 \\
\hline $5^{c}$ & 466 & 289 & & & 600 & 1.00 & - & - & - & 17.3 & - & $8.18 \mathrm{E}-10$ & - & 6.540 \\
\hline 6 & 527 & 289 & & & 600 & 1.00 & - & - & - & 10.4 & - & $3.94 \mathrm{E}-10$ & - & 6.730 \\
\hline 7 & 598 & 289 & 284 & 226 & 600 & 1.00 & - & - & - & 6.0 & - & $1.78 \mathrm{E}-10$ & - & 6.774 \\
\hline 8 & 678 & 289 & -497 & -204 & $<30$ & 1.00 & - & - & - & 6.2 & - & negligible & - & 6.773 \\
\hline 9 & 796 & 289 & & & $<30$ & 1.00 & - & - & - & 10.0 & - & $1.06 \mathrm{E}-11$ & - & 6.784 \\
\hline 10 & 985 & 290 & & & $<30$ & 1.00 & - & - & - & 17.5 & - & $1.13 \mathrm{E}-11$ & - & 6.884 \\
\hline 11 & 1107 & Changin & ig back & to NWC & & 1.00 & - & - & - & 18.0 & - & $1.64 \mathrm{E}-10$ & - & 7.073 \\
\hline 12 & 1153 & 289 & 285 & 199 & 600 & 1.00 & - & - & - & 7.9 & - & $1.61 \mathrm{E}-10$ & - & 7.120 \\
\hline
\end{tabular}

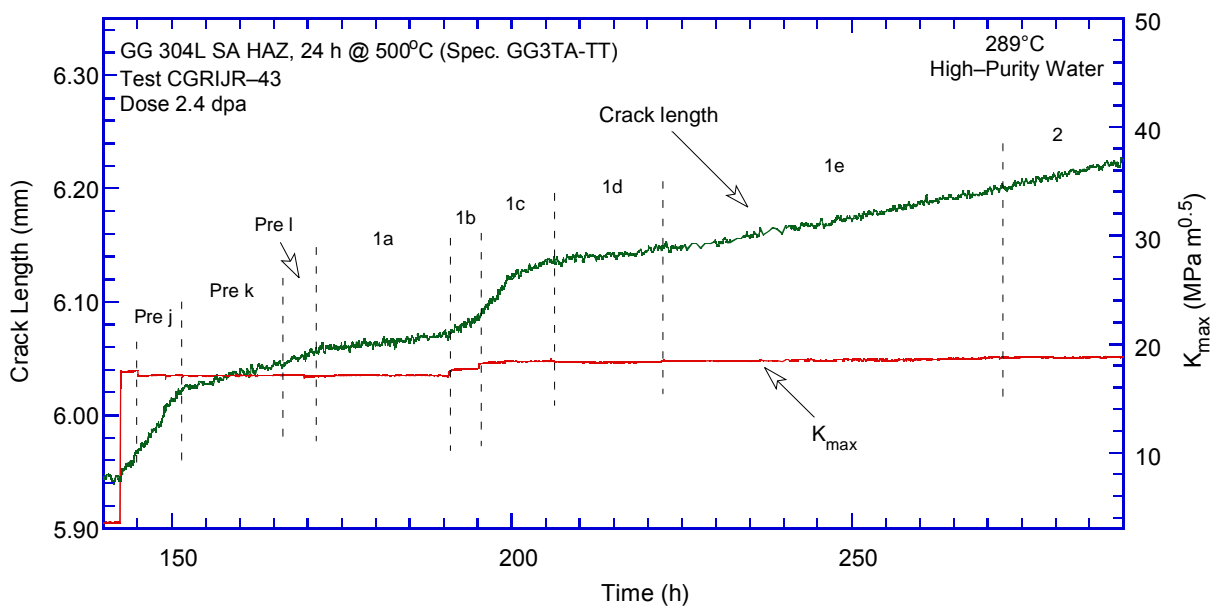

(a)

Figure 6. Crack-length-vs.-time plot for the thermally treated GG 304L SA HAZ specimen $(\approx 2.4$ dpa) in simulated BWR water at $289^{\circ} \mathrm{C}$. 


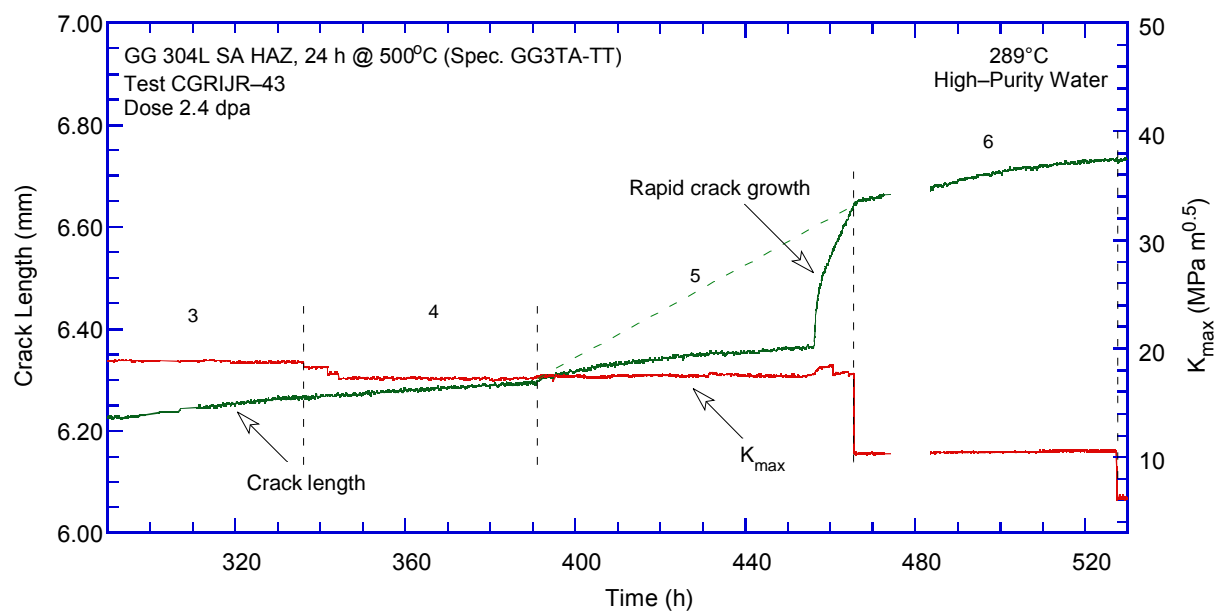

(b)

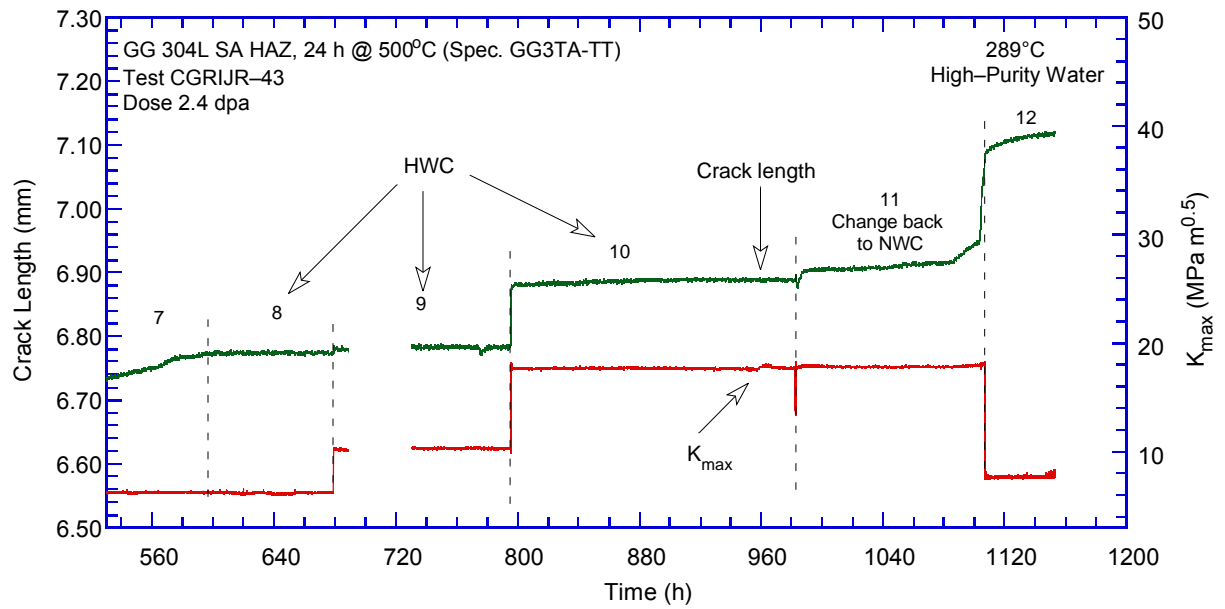

(c)

Figure 6. (Contd.)

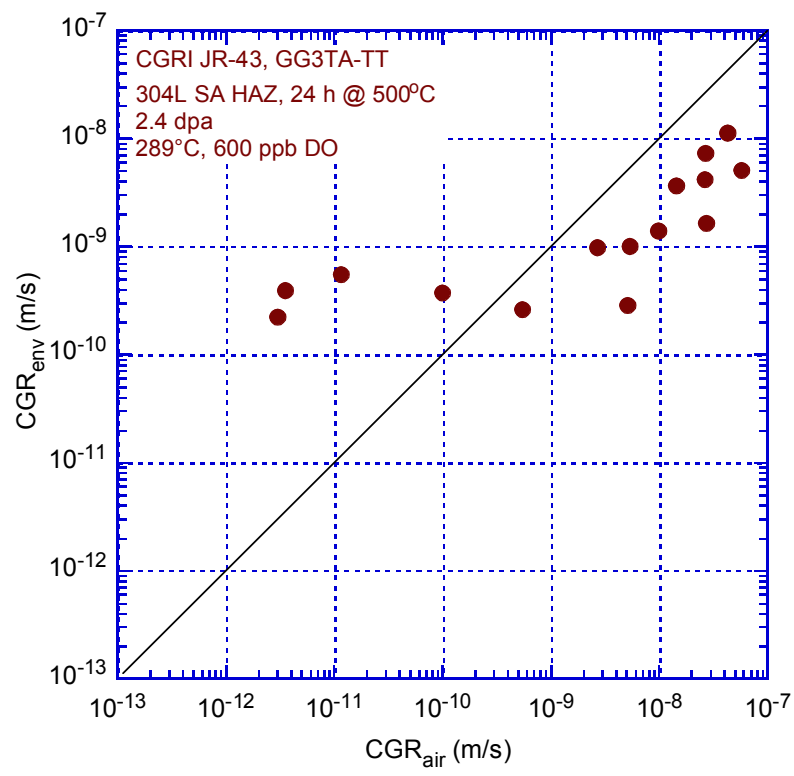

Figure 7. Crack growth rate for GG 304L SA HAZ specimen under cyclic load in simulated BWR NWC water at $\approx 290^{\circ} \mathrm{C}$. 
After nearly $340-\mu \mathrm{m}$ crack advance, environmental enhancement started to appear in test period $1 \mathrm{e}$ at $\mathrm{K}_{\max } \approx 19 \mathrm{MPa} \mathrm{m} \mathrm{m}^{1 / 2}$ and $\mathrm{R} \approx 0.3$ with a slow/fast sawtooth waveform. Further increases in the load ratio (up to $\approx 0.7$ ) and rise time (up to $\approx 700 \mathrm{~s}$ ) did not yield significantly higher CGRs (test period 2-4). Starting from period 5, the CGR test was transferred to the constant-load mode. No periodical unloading was employed for this sample except at the transitions between two constant load stages. One or two unloading cycles to $\mathrm{R} \approx 0.7$ were carried out between two constant-load test stages to break unbroken ligaments. The CGRs in NWC were measured for the test periods at $\approx 6,10$, and $17 \mathrm{MPa} \mathrm{m}^{1 / 2}$, respectively. In period 5, a sudden increase in CGR was observed (as shown in Fig. 6), perhaps due to broken ligaments. An average value for the entire period 5 is, therefore, considered to be a better representation of the CGR for this stage. After the tests in NWC, the DO level in the water environment was reduced to simulate HWC by bubbling $4 \%$ hydrogen balanced with nitrogen in the system. Under the HWC, no crack propagation was detectable at $\approx 6 \mathrm{MPa} \mathrm{m}{ }^{1 / 2}$, and CGRs at $\approx 10$ and $17.5 \mathrm{MPa} \mathrm{m}^{1 / 2}$ were at least one order magnitude lower than the corresponding CGRs in NWC. Figure 8 shows all constant-load CGRs obtained from this specimen in both NWC and HWC.

After the tests in $\mathrm{HWC}$, the DO level in water was recovered by bubbling $1 \% \mathrm{O}_{2}$ balanced with $\mathrm{N}_{2}$ in the system during period 11. The environmentally enhanced cracking in NWC was reconfirmed with limited data in period 12 at $\mathrm{K} \approx 8 \mathrm{MPa} \mathrm{m}^{1 / 2}$, as shown in Fig. 8 .

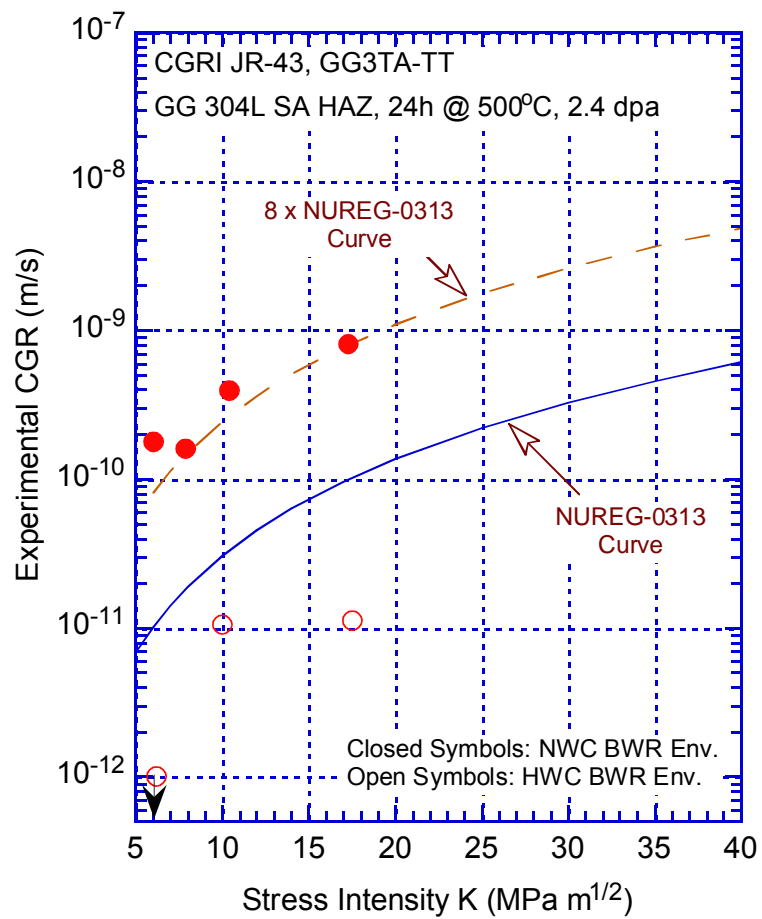

Figure 8. Crack growth rate versus stress intensity under constant-loading condition for the 304L SA HAZ specimen thermally treated at $500^{\circ} \mathrm{C}$ for $24 \mathrm{~h}$ (GG3TA-TT) in simulated BWR NWC and HWC water at $\approx 290^{\circ} \mathrm{C}$.

Following the CGR test, a J-R fracture toughness test was performed on the specimen at $289^{\circ} \mathrm{C}$ in NWC. The test was conducted at an extension rate of $0.43 \mu \mathrm{m} / \mathrm{s}$. Figures 9 and 10 are the load vs. loadline displacement and $\mathrm{J}-\mathrm{R}$ curve, respectively. The $\mathrm{J}$ value of the onset of crack extension $\left(\mathrm{J}_{\mathrm{IC}}\right)$ was determined to be $73 \mathrm{~kJ} / \mathrm{m}^{2}$ for this specimen. After the J-R test, the final crack size was marked by fatigue cycling at room temperature. The specimen was then fractured. Figure 11 shows the final fracture surface and a side view of the broken specimen. The final crack length was about $12 \%$ greater than the DCPD measurement. Accordingly, all DCPD results were scaled up proportionally with the final crack length. 

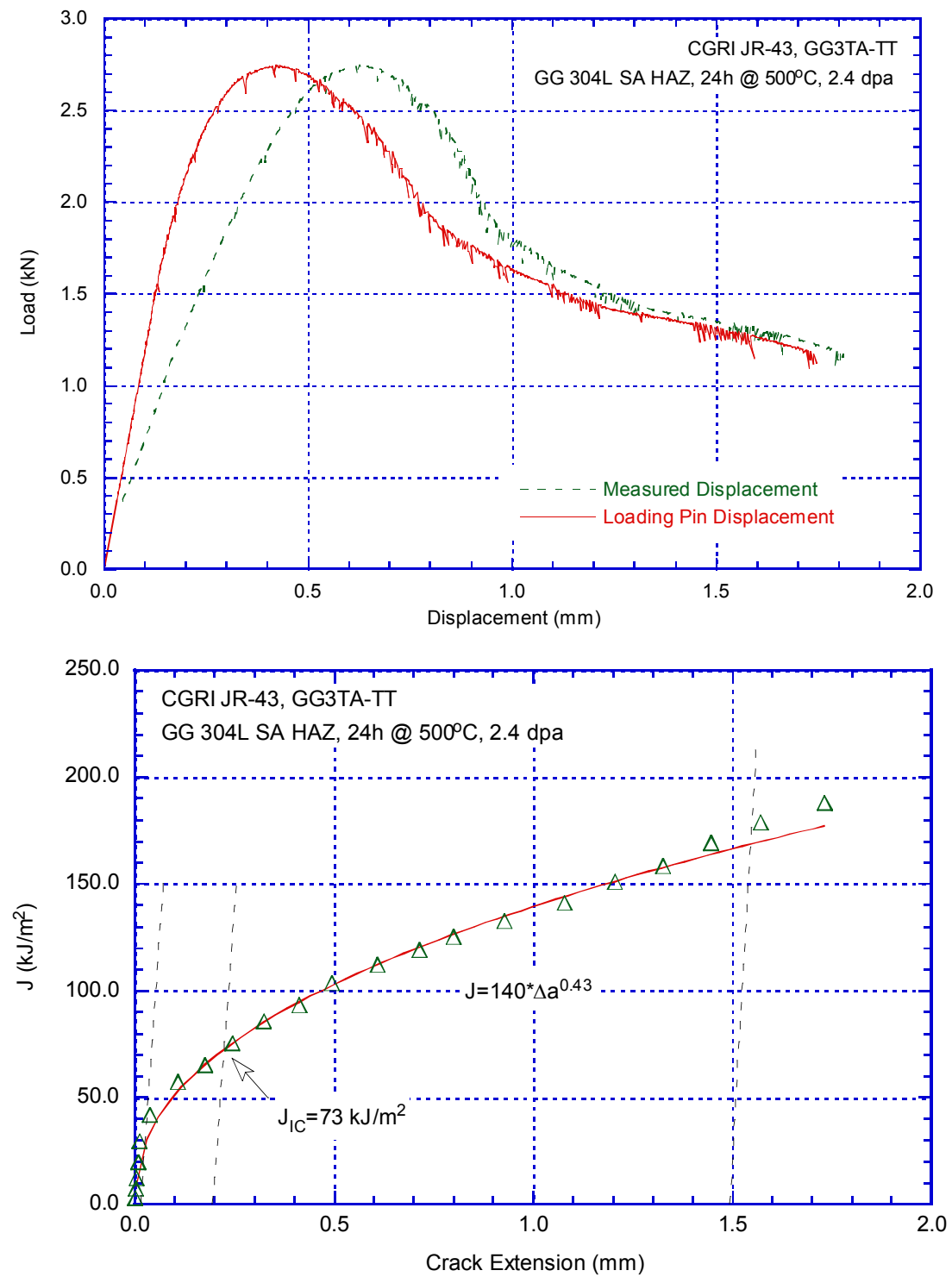

Figure 9. Load vs. load-line displacement curve for the thermally treated $304 \mathrm{~L} S A$ HAZ specimen (GG3TA-TT) tested in NWC at $289^{\circ} \mathrm{C}$.
Figure 10. Fracture toughness $\mathrm{J}-\mathrm{R}$ result for the thermally treated 304L SA HAZ specimen (GG3TA-TT) tested in NWC at $289^{\circ} \mathrm{C}$.

Following the CGR test, a J-R fracture toughness test was performed on the specimen at $289^{\circ} \mathrm{C}$ in NWC. The test was conducted at an extension rate of $0.43 \mu \mathrm{m} / \mathrm{s}$. Figures 9 and 10 are the load vs. loadline displacement and $\mathrm{J}-\mathrm{R}$ curve, respectively. The $\mathrm{J}$ value of the onset of crack extension $\left(\mathrm{J}_{\mathrm{IC}}\right)$ was determined to be $73 \mathrm{~kJ} / \mathrm{m}^{2}$ for this specimen. After the J-R test, the final crack size was marked by fatigue cycling at room temperature. The specimen was then fractured. Figure 11 shows the final fracture surface and a side view of the broken specimen. The final crack length was about $12 \%$ greater than the DCPD measurement. Accordingly, all DCPD results were scaled up proportionally with the final crack length. 


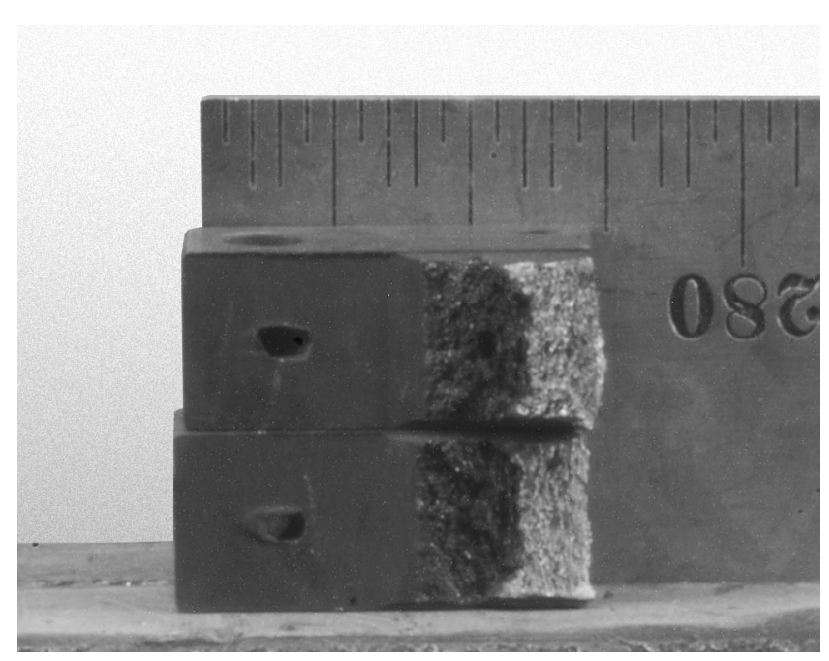

Figure 11. Photograph of the fracture surface of the thermally treated 304L SA HAZ specimen (GG3TA-TT).

\subsection{Type 304 SMA Weld HAZ}

\subsubsection{As-welded Type 304 SMA Weld HAZ Irradiated to 0.75 dpa (85-7B)}

A Type 304 SMA weld HAZ specimen irradiated to $\approx 0.75$ dpa (85-7B) was tested in the simulated BWR environment. The objective of this test was to evaluate the cracking behavior of SMA HAZ at the IASCC threshold dose level. After the specimen was soaked in simulated BWR water with $600 \mathrm{ppb}$ DO for $150 \mathrm{~h}$, fatigue precracking with a triangular waveform was started at $1 \mathrm{~Hz}$. The initial load ratio was 0.3 , and $\mathrm{K}_{\max }$ was about 10 to $15 \mathrm{MPa} \mathrm{m}^{1 / 2}$. The load ratio was increased to 0.5 after a few hours, and $\mathrm{K}_{\max }$ was reduced to $10 \mathrm{MPa} \mathrm{m}{ }^{1 / 2}$. The measured CGR decreased slowly with the increasing load ratio and rise time. At around $5 \times 10^{-10} \mathrm{~m} / \mathrm{s}$, environmental enhancement became evident. Details of the test conditions are given in Table 6 . Figure 12 shows the crack-length-vs.-time curve of this test. Figure 13 is a plot of the cyclic CGR data showing enhanced cracking in simulated BWR water.

Constant-load CGR tests began at period 4. Figure 14 shows the constant-load CGR results obtained from this specimen. In NWC, the constant-load CGR for $\mathrm{K} \approx 5 \mathrm{MPa} \mathrm{m}{ }^{1 / 2}$ is about $2.39 \times 10^{-10} \mathrm{~m} / \mathrm{s}$ at $\approx 290^{\circ} \mathrm{C}$, much higher than that of nonirradiated sensitized $304 \mathrm{SSs}$ (NUREG-0313 curve). Additional tests were also performed in NWC on the specimen at $\approx 10,15$ and $19 \mathrm{MPa} \mathrm{m}{ }^{1 / 2}$. All constant-load CGR results for the current specimen are plotted in Fig. 14 along with the NUREG-0313 disposition curve. The CGRs of this SMA weld HAZ specimen are high even at this low dose level.

Besides the tests at $290^{\circ} \mathrm{C}$, the specimen was also tested in NWC at $\approx 270^{\circ} \mathrm{C}$ and $280^{\circ} \mathrm{C}$ with $\mathrm{K} \approx$ $15 \mathrm{MPa} \mathrm{m}^{1 / 2}$. For every temperature change, sufficient time was allowed to re-stabilize the system (e.g., periods $7 \mathrm{a}, 8 \mathrm{a}$, and $9 \mathrm{a}$ ). The DCPD measurement was also re-initiated to eliminate any effect introduced by the low test temperature. An increasing trend of the CGR was observed with rising test temperature. The temperature dependence of CGR is plotted in Fig. 15. For this specimen, the apparent activation energy for environmentally assisted cracking was determined from Fig. 15 to be $188 \mathrm{~kJ} / \mathrm{mol}$ in NWC at $270-290^{\circ} \mathrm{C}$. 
Table 6. Test results for the Type 304 SMA HAZ specimen at as-welded condition (85-7B, $0.75 \mathrm{dpa})$ in BWR water.

\begin{tabular}{|c|c|c|c|c|c|c|c|c|c|c|c|c|c|c|}
\hline \multirow{2}{*}{$\begin{array}{c}\text { Test } \\
\text { Period } \\
\end{array}$} & \multirow{2}{*}{$\begin{array}{c}\text { Test } \\
\text { Time, } \\
\mathrm{h} \\
\end{array}$} & \multirow{2}{*}{$\begin{array}{c}\text { Test } \\
\text { Temp., } \\
{ }^{\circ} \mathrm{C}\end{array}$} & \multicolumn{2}{|c|}{$\begin{array}{c}\text { ECP, }{ }^{\mathrm{a}} \\
\mathrm{mV} \text { (SHE) }\end{array}$} & \multirow{2}{*}{$\begin{array}{c}\mathrm{O}_{2} \\
\text { Conc., } \\
\text { ppb }\end{array}$} & \multirow{2}{*}{$\begin{array}{c}\mathrm{R} \\
\text { Load } \\
\text { Ratio } \\
\end{array}$} & \multirow{2}{*}{$\begin{array}{c}\text { Rise } \\
\text { Time, } \\
\mathrm{s} \\
\end{array}$} & \multirow{2}{*}{$\begin{array}{c}\text { Return } \\
\text { Time, } \\
\mathrm{s} \\
\end{array}$} & \multirow{2}{*}{$\begin{array}{c}\text { Hold } \\
\text { Time, }^{\mathrm{b}} \\
\mathrm{s}\end{array}$} & \multirow{3}{*}{$\begin{array}{c}\mathrm{K}_{\max } \\
\mathrm{MPa} \mathrm{m}^{1 / 2} \\
\end{array}$} & \multirow{2}{*}{$\begin{array}{c}\Delta \mathrm{K}, \\
\mathrm{MPa} \mathrm{m}^{1 / 2}\end{array}$} & \multirow{2}{*}{$\begin{array}{c}\text { CGR in } \\
\text { Env., } \\
\text { m/s }\end{array}$} & \multirow{2}{*}{$\begin{array}{c}\text { CGR in } \\
\text { Air, } \\
\mathrm{m} / \mathrm{s}\end{array}$} & \multirow{2}{*}{$\begin{array}{c}\text { Crack } \\
\text { Length, } \\
\mathrm{mm}\end{array}$} \\
\hline & & & $\mathrm{Pt}$ & Steel & & & & & & & & & & \\
\hline & & & & & & & & & & & & & & 5.834 \\
\hline Pre a & 3 & 289 & & & 600 & 0.32 & 0.41 & 0.41 & $0.09 / 0.09$ & 9.8 & 6.7 & negligible & $6.95 \mathrm{E}-09$ & 5.832 \\
\hline Pre b & 4 & 289 & & & & 0.30 & 0.44 & 0.44 & $0.06 / 0.06$ & 15.3 & 10.7 & 3.23E-08 & 3.03E-08 & 5.913 \\
\hline $1 \mathrm{a}$ & 5 & 289 & & & & 0.58 & 0.80 & 0.80 & $0.20 / 0.20$ & 15.2 & 6.3 & $2.57 \mathrm{E}-08$ & 3.89E-09 & 5.946 \\
\hline $1 \mathrm{~b}$ & 9 & 289 & & & & 0.50 & 0.76 & 0.76 & $0.24 / 0.24$ & 10.1 & 5.1 & $6.57 \mathrm{E}-09$ & $1.80 \mathrm{E}-09$ & 5.975 \\
\hline $1 \mathrm{c}$ & 10 & 289 & & & & 0.70 & 0.66 & 0.66 & $0.34 / 0.34$ & 10.1 & 3.0 & 7.19E-09 & $4.57 \mathrm{E}-10$ & 5.991 \\
\hline $2 a$ & 13 & 289 & & & & 0.72 & 3.22 & 0.64 & $1.78 / 0.36$ & 10.0 & 2.8 & $1.34 \mathrm{E}-09$ & $7.40 \mathrm{E}-11$ & 5.999 \\
\hline $2 b$ & 21 & 290 & 273 & 226 & & 0.72 & 6.45 & 0.64 & $3.55 / 0.36$ & 10.0 & 2.8 & $6.22 \mathrm{E}-10$ & $3.85 \mathrm{E}-11$ & 6.001 \\
\hline $2 \mathrm{c}$ & 26 & 289 & 277 & 225 & & 0.69 & 19.9 & 7.94 & $10.1 / 4.0$ & 10.1 & 3.1 & $5.40 \mathrm{E}-10$ & $1.59 \mathrm{E}-11$ & 6.016 \\
\hline $2 \mathrm{~d}$ & 44 & 289 & 281 & 232 & & 0.69 & 200 & 8.00 & $100 / 4.0$ & 10.1 & 3.2 & $4.48 \mathrm{E}-10$ & $1.71 \mathrm{E}-12$ & 6.034 \\
\hline $3 a$ & 68 & 290 & & & & 0.68 & 154 & 6.16 & $146 / 5.8$ & 5.2 & 1.7 & $4.89 \mathrm{E}-10$ & $2.69 \mathrm{E}-13$ & 6.055 \\
\hline $3 b$ & 92 & 289 & 281 & 235 & 600 & 0.74 & 458 & 5.50 & $542 / 6.5$ & 5.1 & 1.3 & $4.79 \mathrm{E}-10$ & $4.68 \mathrm{E}-14$ & 6.073 \\
\hline 4 & 141 & 289 & 281 & 238 & & 1.0 & - & - & - & 5.2 & - & $2.39 \mathrm{E}-10$ & - & 6.116 \\
\hline 5 & 171 & 289 & 283 & 242 & & 1.0 & - & - & - & 9.9 & - & $5.58 \mathrm{E}-10$ & - & 6.200 \\
\hline 6 & 199 & 289 & 283 & 244 & & 1.0 & - & - & - & 15.3 & - & $9.38 \mathrm{E}-10$ & - & 6.263 \\
\hline 7 & 220 & 289 & 281 & 243 & & 1.0 & - & - & - & 19.1 & - & $1.33 \mathrm{E}-09$ & - & 6.486 \\
\hline $7 \mathrm{a}$ & 249 & \multicolumn{3}{|c|}{ Decrease temperature } & & 1.0 & - & - & - & 3.0 & - & - & - & - \\
\hline 8 & 288 & 269 & 285 & 247 & & 1.0 & - & - & - & 15.4 & - & $2.10 \mathrm{E}-10$ & - & 6.547 \\
\hline $8 \mathrm{a}$ & 308 & \multicolumn{3}{|c|}{ Increase temperature } & & 1.0 & - & - & - & 4.8 & - & - & - & - \\
\hline 9 & 337 & 280 & 285 & 245 & & 1.0 & - & - & - & 15.3 & - & $4.24 \mathrm{E}-10$ & - & 6.597 \\
\hline $9 \mathrm{a}$ & 355 & \multicolumn{3}{|c|}{ Increase temperature } & & 1.0 & - & - & - & 4.8 & - & - & - & - \\
\hline $9 b$ & 358 & \multicolumn{3}{|c|}{289} & & 1.0 & - & - & - & 15.3 & - & $7.74 \mathrm{E}-10$ & - & 6.630 \\
\hline $9 \mathrm{c}$ & 373 & \multicolumn{3}{|c|}{ Reduce DO } & & 1.0 & - & - & - & 15.3 & - & - & - & - \\
\hline 10 & 537 & 289 & -488 & -183 & $<50$ & 1.0 & - & - & - & 15.4 & - & $6.36 \mathrm{E}-12$ & - & 6.662 \\
\hline $10 \mathrm{a}$ & 574 & \multicolumn{3}{|c|}{ Increase DO } & & 1.0 & - & - & - & 15.2 & - & - & - & - \\
\hline $10 \mathrm{~b}$ & 585 & 289 & 259 & 236 & 600 & 1.0 & - & - & - & 15.4 & - & 7.77E-10 & - & 6.700 \\
\hline
\end{tabular}

a Represents values in the effluent. In the feedwater, conductivity was $\approx 0.08 \mu \mathrm{S} / \mathrm{cm}$, and DO was $\approx 800$ to $1000 \mathrm{ppb}$.

$\mathrm{b}$ Hold periods at minimum load during the loading cycle and at maximum load during the unloading cycle.

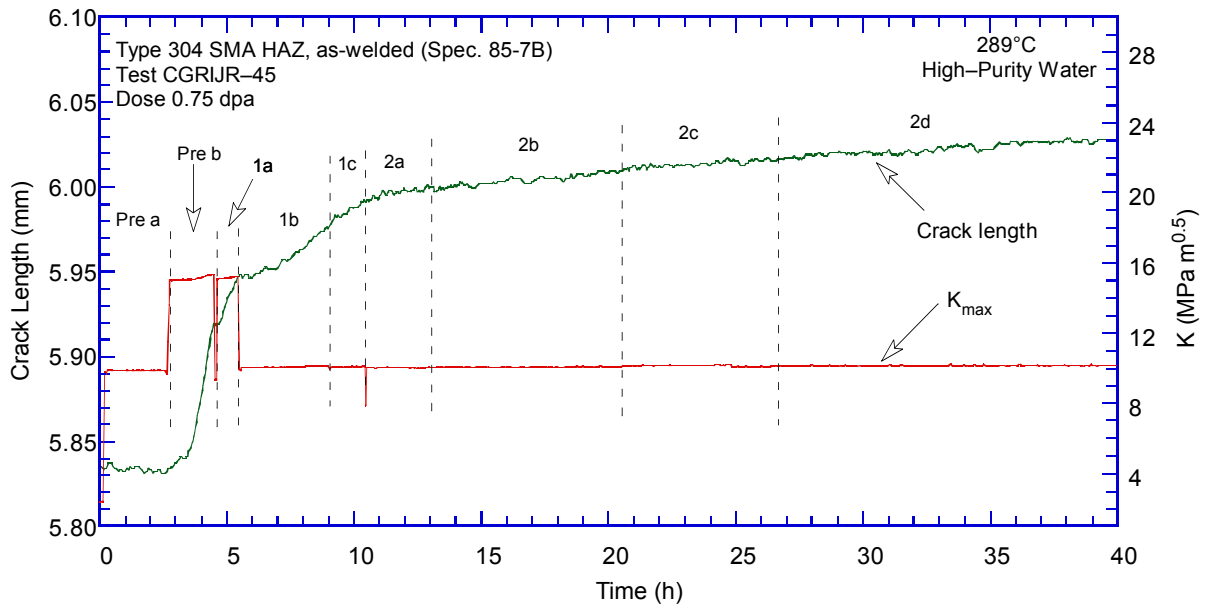

(a)

Figure 12. Crack-length-vs.-time plot for the as-welded Type 304 SMA HAZ specimen (85-7B, 0.75 dpa) in BWR water at $289^{\circ} \mathrm{C}$. 


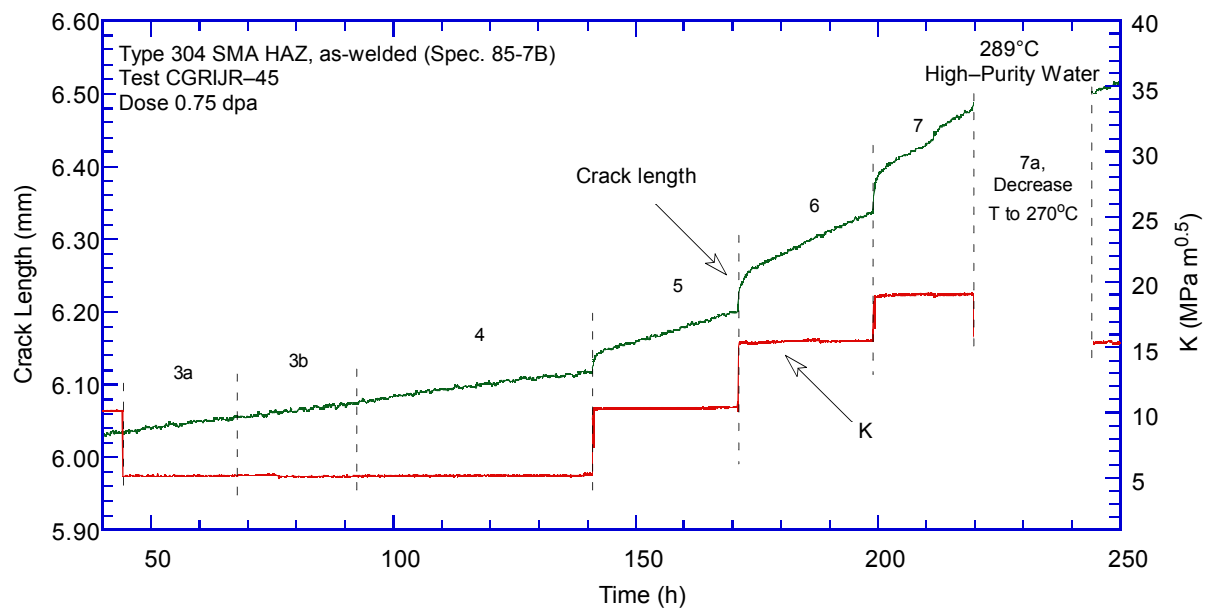

(b)

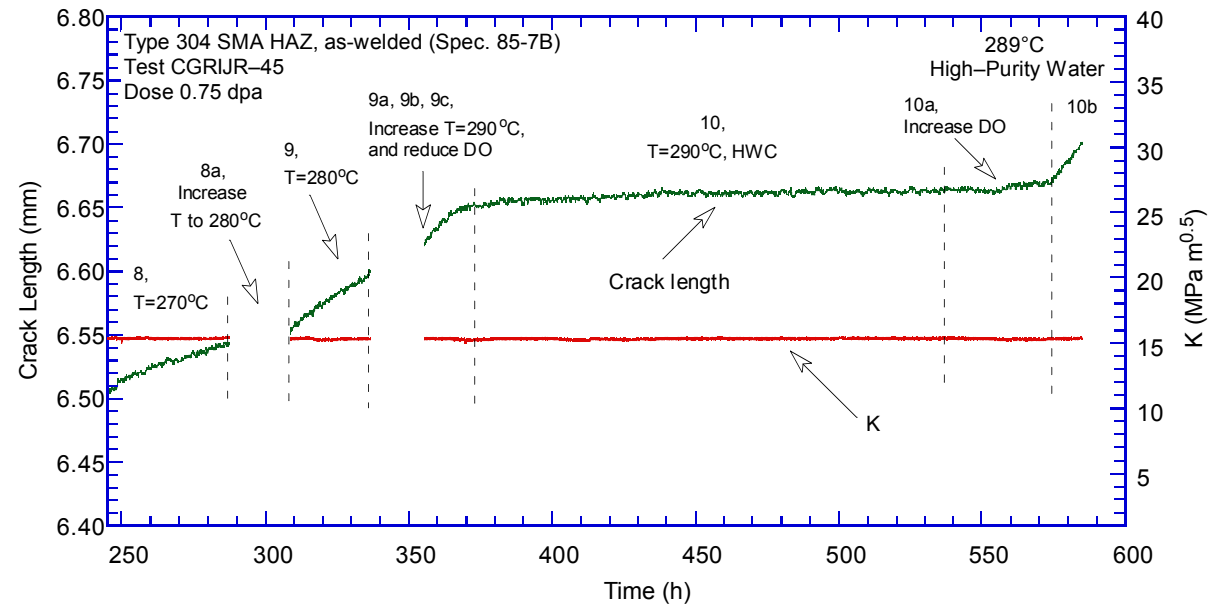

(c)

\section{Figure 12. (Contd.)}

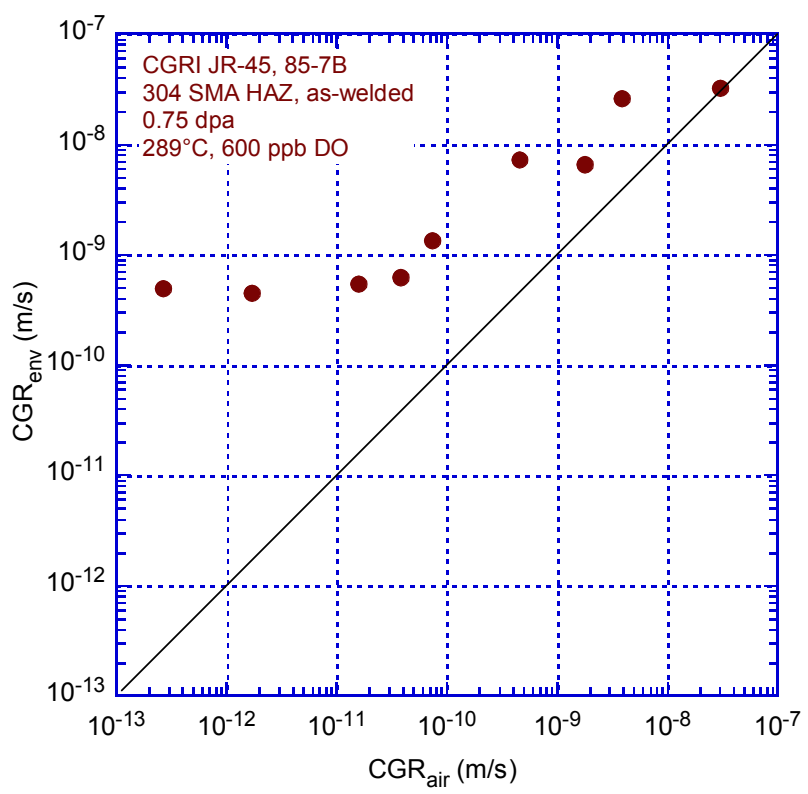

Figure 13. Cyclic crack growth rate for the as-welded Type 304 SMA HAZ specimen (85-7B) irradiated to $0.75 \mathrm{dpa}$. 


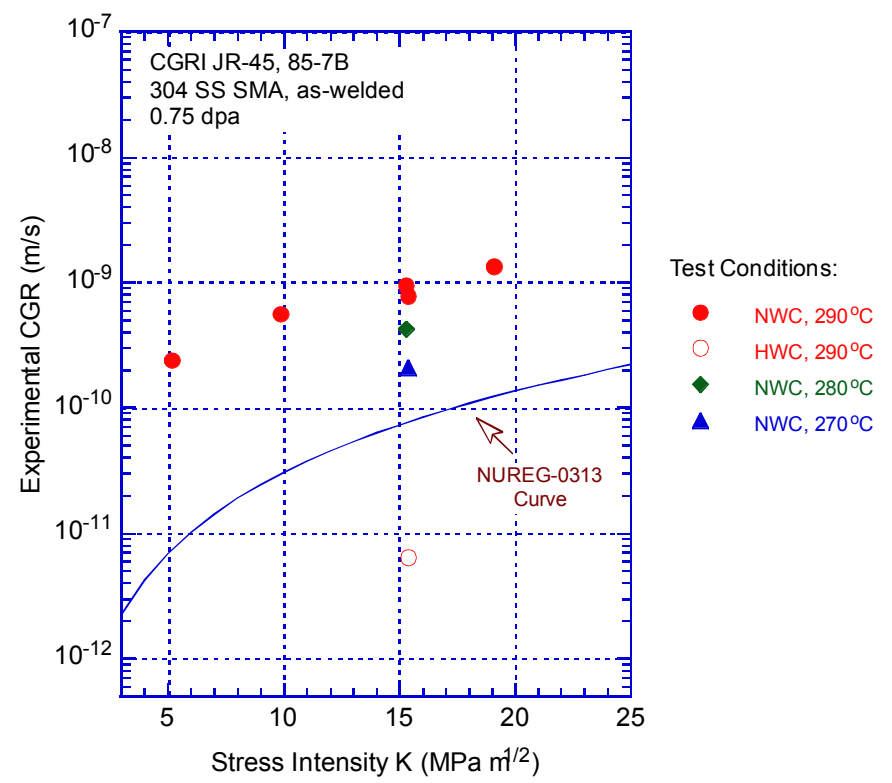

Figure 14. Crack growth rate versus stress intensity under constant-loading conditions for the as-welded Type 304 SMA HAZ specimen (85-7B) irradiated to $0.75 \mathrm{dpa}$.

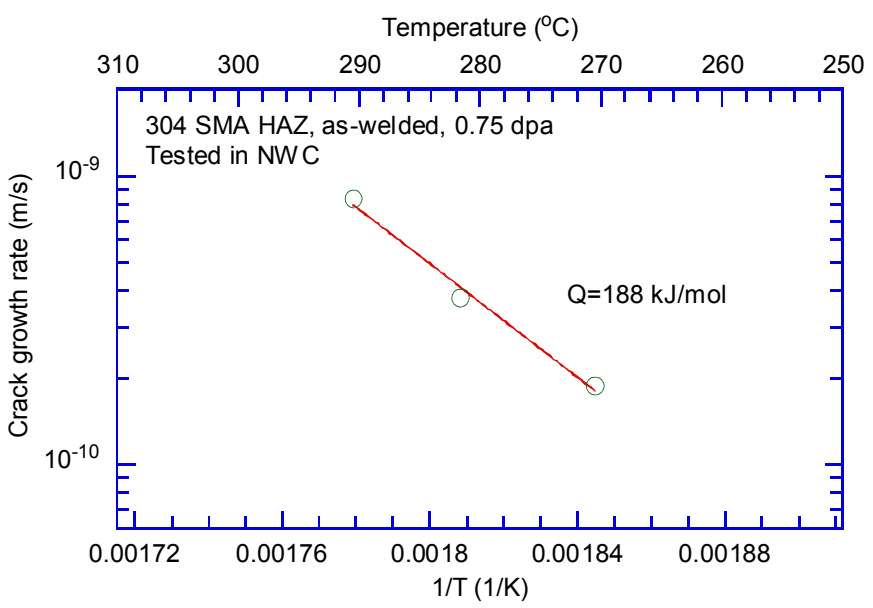

Figure 15. Temperature dependence of crack growth rate for the as-welded 304 SMA HAZ specimen (85-7B, 0.75 dpa)

The effect of $\mathrm{HWC}$ on constant-load CGR was investigated at $\approx 290^{\circ} \mathrm{C}$ with this specimen. After CGR tests in NWC, the DO level in the simulated environment was reduced by bubbling $4 \%$ hydrogen mixed with nitrogen in the system. Consequently, the CGR at $\approx 15 \mathrm{MPa} \mathrm{m}^{1 / 2}$ was nearly two orders of magnitude lower than that in NWC.

After the CGR test, a J-R test was performed to obtain the fracture toughness of this specimen in NWC. The test was conducted under displacement control at a constant extension rate of $0.43 \mu \mathrm{m} / \mathrm{s}$. During the test, loading was interrupted periodically to measure the crack length. A relaxation time of $30 \mathrm{~s}$ was allowed before each DCPD measurement. Figures 16 and 17 show the obtained load vs. loadline displacement and the corresponding J-R curve, respectively. The power-law fitting of the data suggests a $\mathrm{J}_{\mathrm{IC}}$ of $94 \mathrm{~kJ} / \mathrm{m}^{2}$ at $0.2-\mathrm{mm}$ crack extension.

The final crack front was marked by fatigue cycling at room temperature in air. The specimen was then fractured, and optical images of the fracture surface were taken (Fig. 18). The final crack length measured on the fracture surface was approximately $13 \%$ greater than the value determined by the DCPD method. Accordingly, the previous crack extension results obtained from DCPT measurement were scaled proportionately. 

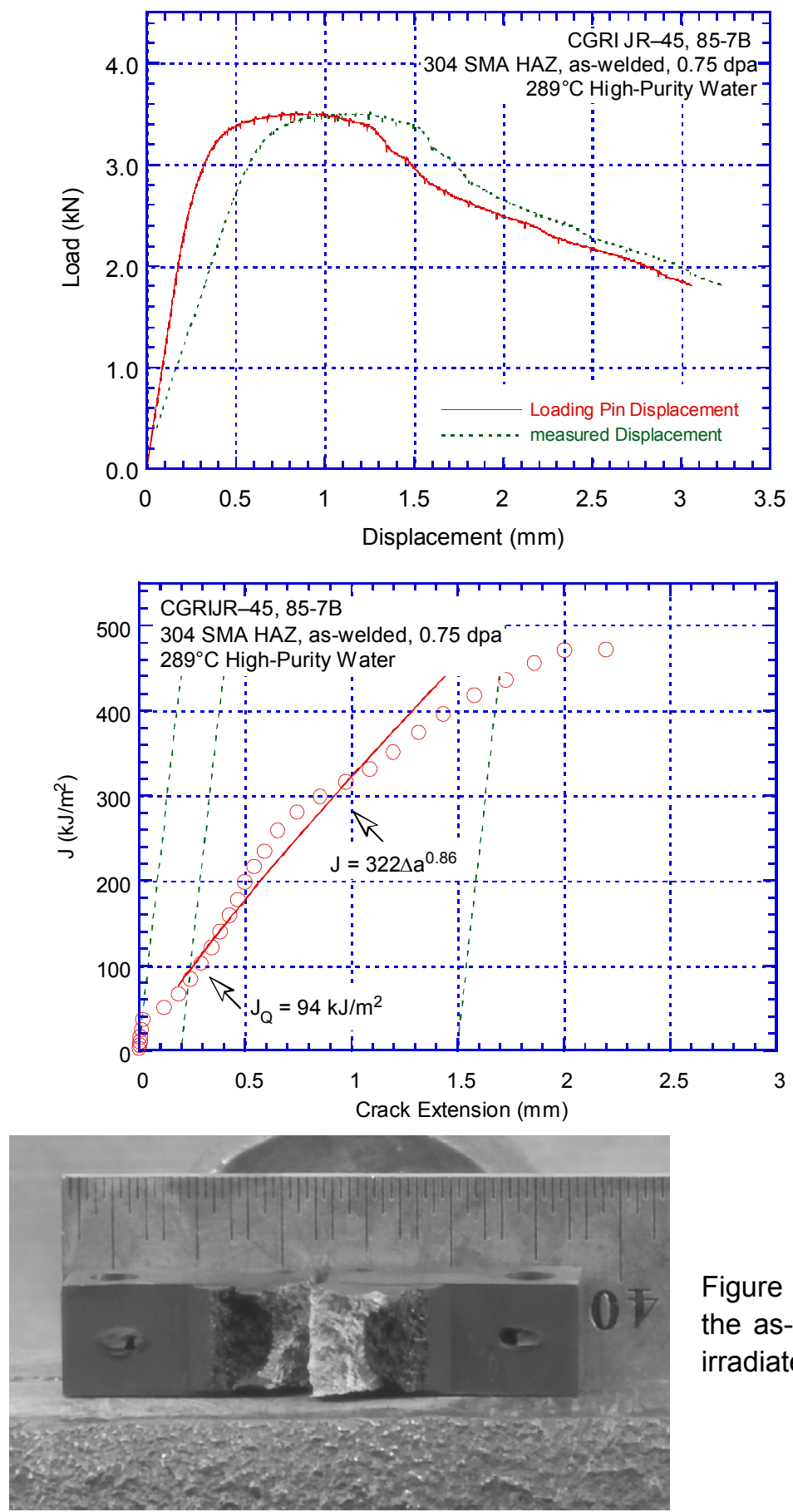

Figure 16. Load vs. load-line displacement curve for the as-welded Type 304 SMA HAZ specimen (85-7B) tested in NWC at $289^{\circ} \mathrm{C}$.
Figure 17. Fracture toughness J-R curves for the as-welded Type 304 SMA HAZ specimen (85-7B) tested in NWC at $289^{\circ} \mathrm{C}$.
Figure 18. Photograph of the fracture surface of the as-welded 304 SMA HAZ specimen (85-7B) irradiated to $0.75 \mathrm{dpa}$.

\subsubsection{Thermally Treated Type 304 SMA Weld HAZ Irradiated to 2 dpa (85-2ATT)}

A CGR test was performed on a Type 304 SMA weld HAZ specimen (85-2ATT) irradiated to 2.1 dpa. The specimen was thermally treated at $500^{\circ} \mathrm{C}$ for 24 hours prior to irradiation. The objective of this test was to investigate the effect of low-temperature sensitization and to provide additional information on the dose dependence of IASCC susceptibility for the Type 304 SMA weld HAZ. Table 7 summarizes details of test periods, and Fig. 19 shows the crack-extension-vs.-time curve for this specimen. 
Table 7. Test results for a thermally treated 304 SMA HAZ specimen irradiated to 2 dpa (85-2ATT).

\begin{tabular}{|c|c|c|c|c|c|c|c|c|c|c|c|c|c|c|}
\hline \multirow{2}{*}{$\begin{array}{c}\text { Test } \\
\text { Period } \\
\end{array}$} & \multirow{2}{*}{$\begin{array}{c}\text { Test } \\
\text { Time, } \\
\text { h }\end{array}$} & \multirow{2}{*}{$\begin{array}{c}\text { Test } \\
\text { Tem } \\
\mathrm{p} \\
{ }^{\circ} \mathrm{C} \\
\end{array}$} & \multicolumn{2}{|c|}{$\begin{array}{c}\text { ECPa } \\
\mathrm{mV}(\mathrm{SHE})\end{array}$} & \multirow{2}{*}{$\begin{array}{c}\mathrm{O}_{2} \\
\text { Conc., }{ }^{\mathrm{a}} \\
\mathrm{ppb}\end{array}$} & \multirow{2}{*}{$\begin{array}{c}\text { R } \\
\text { Load } \\
\text { Ratio } \\
\end{array}$} & \multirow{2}{*}{$\begin{array}{c}\text { Rise } \\
\text { Time, } \\
\text { s }\end{array}$} & \multirow{2}{*}{$\begin{array}{c}\text { Return } \\
\text { Time, } \\
\text { s } \\
\end{array}$} & \multirow{2}{*}{$\begin{array}{c}\text { Hold } \\
\text { Time, } \\
\text { s }\end{array}$} & \multirow{2}{*}{$\begin{array}{c}\mathrm{K}_{\max } \\
\mathrm{MPa} \mathrm{m}^{1 / 2}\end{array}$} & \multirow{2}{*}{$\begin{array}{c}\Delta \mathrm{K} \\
\mathrm{MPa} \mathrm{m} \\
\end{array}$} & \multirow{2}{*}{$\begin{array}{c}\text { CGR in } \\
\text { Env., } \\
\text { m/s }\end{array}$} & \multirow{2}{*}{$\begin{array}{c}\text { CGR in } \\
\text { air } \\
\mathrm{m} / \mathrm{s}\end{array}$} & \multirow{2}{*}{$\begin{array}{r}\text { Crack } \\
\text { Length, } \\
\text { mm }\end{array}$} \\
\hline & & & $\mathrm{Pt}$ & Steel & & & & & & & & & & \\
\hline Pre a & 3 & 290 & & & & & & & & & & & & 5.771 \\
\hline Pre b & $\begin{array}{l}5 \\
6\end{array}$ & 290 & 256 & 223 & 600 & $\begin{array}{l}0.43 \\
0.32\end{array}$ & $\begin{array}{l}0.16 \\
0.39\end{array}$ & $\begin{array}{l}0.16 \\
0.39\end{array}$ & $\begin{array}{l}0.09 / 0.09 \\
0.11 / 0.11\end{array}$ & $\begin{array}{c}6.2 \\
10.0\end{array}$ & $\begin{array}{l}3.5 \\
6.8\end{array}$ & - & $\begin{array}{l}2.24 \mathrm{E}-9 \\
7.59 \mathrm{E}-9\end{array}$ & $\begin{array}{l}5.771 \\
5.773\end{array}$ \\
\hline Pre c & 7 & 290 & 259 & 226 & & 0.30 & 0.43 & 0.43 & $0.07 / 0.07$ & 15.3 & 10.8 & $1.15 \mathrm{E}-08$ & $3.07 \mathrm{E}-8$ & 5.802 \\
\hline Pre d & 23 & 290 & 268 & 234 & & 0.29 & 0.43 & 0.43 & $0.07 / 0.07$ & 15.5 & 10.9 & $3.14 \mathrm{E}-08$ & $3.21 \mathrm{E}-8$ & 5.855 \\
\hline $1 \mathrm{a}$ & 25 & 290 & 269 & 235 & & 0.29 & 0.86 & 0.86 & $0.14 / 0.14$ & 15.3 & 10.8 & $1.79 \mathrm{E}-08$ & $1.55 \mathrm{E}-8$ & 5.903 \\
\hline $1 \mathrm{~b}$ & 30 & 290 & 267 & 233 & & 0.49 & 0.807 & 0.81 & $0.19 / 0.19$ & 15.4 & 7.8 & 3.46E-09 & $6.95 \mathrm{E}-9$ & 5.937 \\
\hline $2 a$ & 46 & 290 & 267 & 233 & & 0.51 & 2.4 & 0.8 & $0.6 / 0.2$ & 15.2 & 7.5 & - & $2.05 \mathrm{E}-9$ & 5.944 \\
\hline $2 b$ & 51 & 290 & 268 & 234 & & 0.49 & 1.61 & 1.61 & $0.39 / 0.39$ & 15.3 & 7.8 & - & $3.40 \mathrm{E}-9$ & 5.943 \\
\hline $2 \mathrm{c}$ & 53 & 290 & 267 & 232 & & 0.49 & 0.40 & 0.40 & $0.1 / 0.1$ & 15.3 & 7.8 & - & $1.37 \mathrm{E}-8$ & 5.947 \\
\hline $3 a$ & 55 & 290 & 266 & 231 & & 0.29 & 0.43 & 0.43 & $0.07 / 0.07$ & 15.3 & 10.8 & - & $3.13 \mathrm{E}-8$ & 5.949 \\
\hline $3 b$ & 74 & 290 & 271 & 235 & & 0.30 & 0.45 & 0.45 & $0.05 / 0.05$ & 15.0 & 10.5 & - & $2.77 \mathrm{E}-8$ & 5.936 \\
\hline $3 \mathrm{c}$ & 75 & 290 & 269 & 235 & & 0.29 & 0.46 & 0.46 & $0.04 / 0.04$ & 16.6 & 11.8 & $2.36 \mathrm{E}-08$ & $3.94 \mathrm{E}-8$ & 5.989 \\
\hline $3 d$ & 76 & 290 & 269 & 234 & & 0.30 & 0.90 & 0.90 & $0.1 / 0.1$ & 15.1 & 10.6 & - & $1.42 \mathrm{E}-8$ & 5.994 \\
\hline $3 \mathrm{e}$ & 78 & 290 & 269 & 234 & & 0.28 & 0.91 & 0.91 & $0.09 / 0.09$ & 16.7 & 11.9 & $1.27 \mathrm{E}-08$ & $2.04 \mathrm{E}-8$ & 6.029 \\
\hline $3 \mathrm{f}$ & 80 & 290 & 269 & 235 & & 0.51 & 0.88 & 0.88 & $0.12 / 0.12$ & 16.7 & 8.3 & $6.81 \mathrm{E}-09$ & $8.01 \mathrm{E}-9$ & 6.059 \\
\hline $4 a$ & 114 & 290 & 269 & 235 & & 0.31 & 4.54 & 0.91 & $0.46 / 0.09$ & 16.6 & 11.4 & $5.97 \mathrm{E}-11$ & 3.67E-9 & 6.069 \\
\hline $4 b$ & 167 & 290 & 274 & 239 & & 0.31 & 2.72 & 0.91 & $0.28 / 0.09$ & 16.7 & 11.4 & $1.41 \mathrm{E}-10$ & $6.16 \mathrm{E}-9$ & 6.084 \\
\hline $4 c$ & 215 & 290 & 273 & 240 & 600 & 0.32 & 9.08 & 0.91 & $0.92 / 0.09$ & 16.9 & 11.5 & $7.61 \mathrm{E}-11$ & $1.90 \mathrm{E}-9$ & 6.099 \\
\hline $4 d$ & 244 & 290 & 274 & 240 & & 0.51 & 8.74 & 0.85 & $1.26 / 0.15$ & 16.9 & 8.2 & $9.12 \mathrm{E}-11$ & $7.86 \mathrm{E}-10$ & 6.109 \\
\hline $4 \mathrm{e}$ & 272 & 290 & 275 & 243 & & 0.71 & 8.04 & 0.80 & $1.96 / 0.20$ & 16.9 & 4.9 & $1.74 \mathrm{E}-10$ & $1.81 \mathrm{E}-10$ & 6.122 \\
\hline $5 \mathrm{a}$ & 312 & 290 & - & - & & 0.70 & 24.32 & 4.05 & $5.68 / 0.95$ & 16.9 & 5.1 & $1.24 \mathrm{E}-10$ & $6.83 \mathrm{E}-11$ & 6.137 \\
\hline $5 b$ & 335 & 290 & - & - & & 0.70 & 244 & 9.74 & $56 / 2.26$ & 16.9 & 5.1 & $1.50 \mathrm{E}-10$ & 7.07E-12 & 6.145 \\
\hline $5 \mathrm{c}$ & 337 & 290 & - & - & & 0.66 & 829 & 9.95 & $171 / 2.05$ & 17.0 & 5.8 & 4.22E-09 & $3.01 \mathrm{E}-12$ & 6.160 \\
\hline $5 \mathrm{~d}$ & 345 & 290 & 264 & 218 & & 0.69 & 723 & 8.68 & $277 / 3.32$ & 10.1 & 3.1 & $5.30 \mathrm{E}-10$ & $4.62 \mathrm{E}-13$ & 6.169 \\
\hline $5 \mathrm{e}$ & 358 & 290 & 273 & 231 & & 0.68 & 616 & 7.40 & $384 / 4.60$ & 6.1 & 1.9 & $5.73 \mathrm{E}-10$ & $1.10 \mathrm{E}-13$ & 6.185 \\
\hline 6 & 431 & 290 & 272 & 236 & 600 & 1.0 & - & - & - & 6.2 & - & $2.00 \mathrm{E}-10$ & - & 6.243 \\
\hline 7 & 502 & 290 & 267 & 239 & & 1.0 & - & - & - & 10.3 & - & $2.76 \mathrm{E}-10$ & - & 6.327 \\
\hline 8 & 526 & 290 & - & - & & 1.0 & - & - & - & 15.3 & - & $7.28 \mathrm{E}-10$ & - & 6.455 \\
\hline $8 a$ & 550 & & Transit & $\mathrm{n}$ to 27 & & & & & & & & & & \\
\hline 9 & 622 & 270 & 269 & 236 & 600 & 1.0 & - & - & - & 15.2 & - & $2.32 \mathrm{E}-10$ & - & 6.488 \\
\hline $9 \mathrm{a}$ & 655 & & Transit & $\mathrm{n}$ to 28 & & & & & & & & & & \\
\hline 10 & 790 & 280 & 274 & 244 & 600 & 1.0 & - & - & - & 15.1 & - & $7.26 \mathrm{E}-11$ & - & 6.529 \\
\hline $10 \mathrm{a}$ & 815 & & Transit & $\mathrm{n}$ to 29 & & & & & & & & & & \\
\hline 11 & 1200 & 289 & 269 & 244 & 600 & 1.0 & - & - & - & 15.3 & - & $5.71 \mathrm{E}-11$ & - & 6.619 \\
\hline $11 \mathrm{a}$ & 1207 & 290 & -487 & -128 & & 1.0 & - & - & - & 15.4 & - & negligible & - & 6.620 \\
\hline 12 & 1420 & 290 & -485 & -291 & $<30$ & 1.0 & - & - & - & 15.3 & - & negligible & - & 6.616 \\
\hline
\end{tabular}

Represents values in the effluent. In the feedwater, conductivity was $\approx 0.08 \mu \mathrm{S} / \mathrm{cm}$ and DO was $\approx 800$ to $1000 \mathrm{ppb}$.

$\mathrm{b}$ Hold periods at minimum load during the loading cycle and at maximum load during the unloading cycle.

The initial fatigue precracking for this sample was performed with a triangular waveform, at $\mathrm{K}_{\max }=10^{-15} \mathrm{MPa} \mathrm{m}{ }^{1 / 2}, \mathrm{R} \approx 0.3$, and $1 \mathrm{~Hz}$ frequency. After about $250-\mu \mathrm{m}$ crack extension, the triangular waveform was changed to slow/fast sawtooth waveform with 5-s rise time and 1-s return time. Environmentally enhanced cracking was difficult to establish in this specimen, and the transition from triangular to slow/fast sawtooth loading had to be repeated several times between test periods 2 and 4 . Finally, after another $\approx 100 \mu \mathrm{m}$ crack extension, environmental cracking started to appear in test period $4 \mathrm{e}$. During test periods $5 \mathrm{a}-5 \mathrm{e}$, cyclic CGRs were obtained at $\mathrm{K}_{\max } \approx 17,10$, and $6 \mathrm{MPa} \mathrm{m}^{1 / 2}$. After the cyclic CGR test, the test condition was switched to constant load, and CGRs were obtained at $\mathrm{K} \approx 6$, 10 , and 15 $\mathrm{MPa} \mathrm{m}{ }^{1 / 2}$ in NWC at $290^{\circ} \mathrm{C}$. Constant-load CGR tests were also performed at $\approx 270$ and $280^{\circ} \mathrm{C}$ in NWC. In HWC, no measurable crack extension was observed for $\mathrm{K} \approx 15 \mathrm{MPa} \mathrm{m}{ }^{1 / 2}$ at $290^{\circ} \mathrm{C}$ after more than 200 hours. 


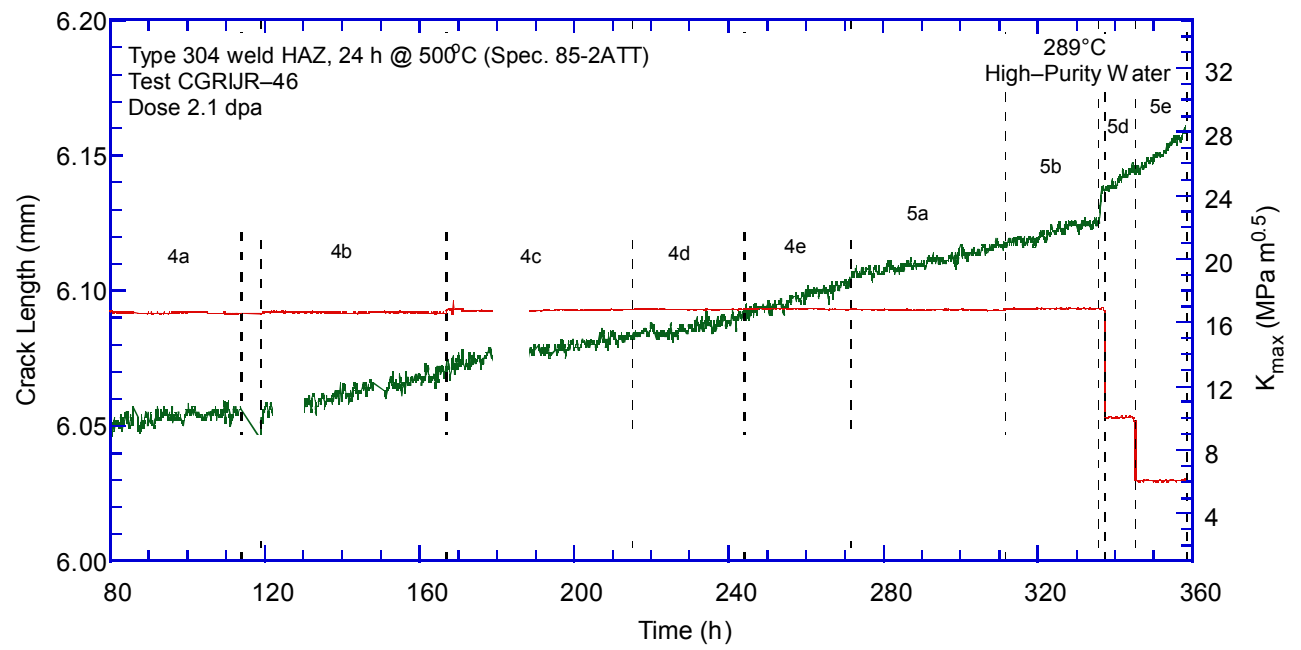

(a)

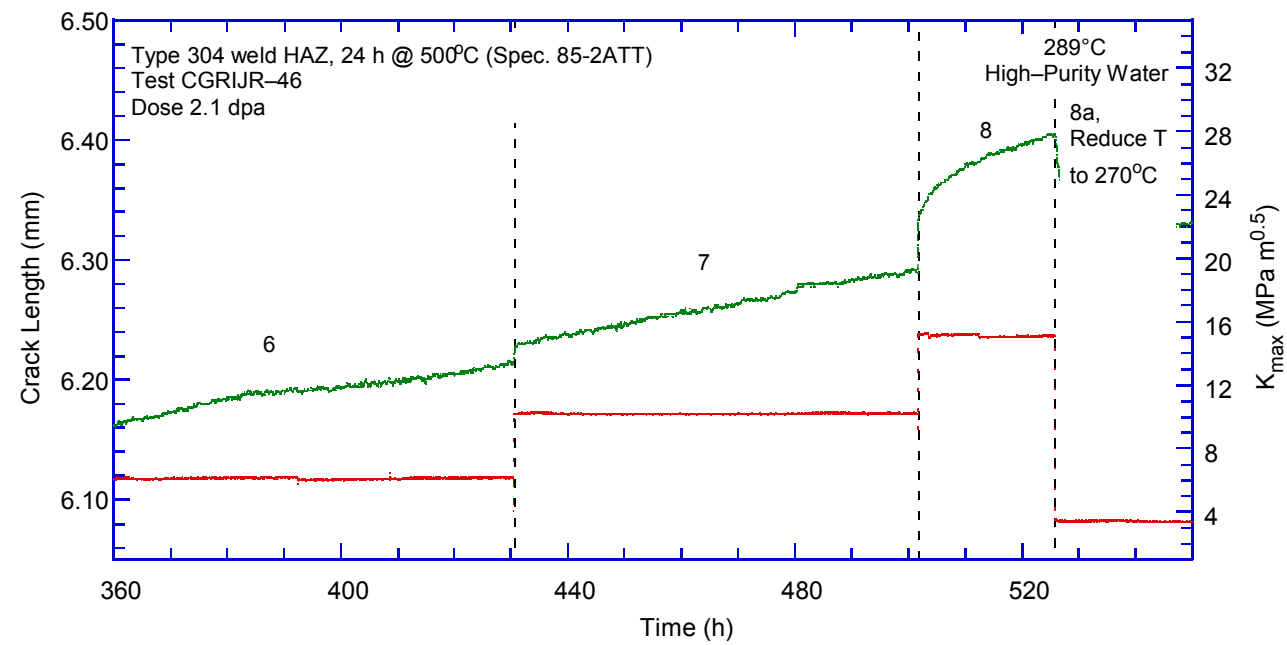

(b)

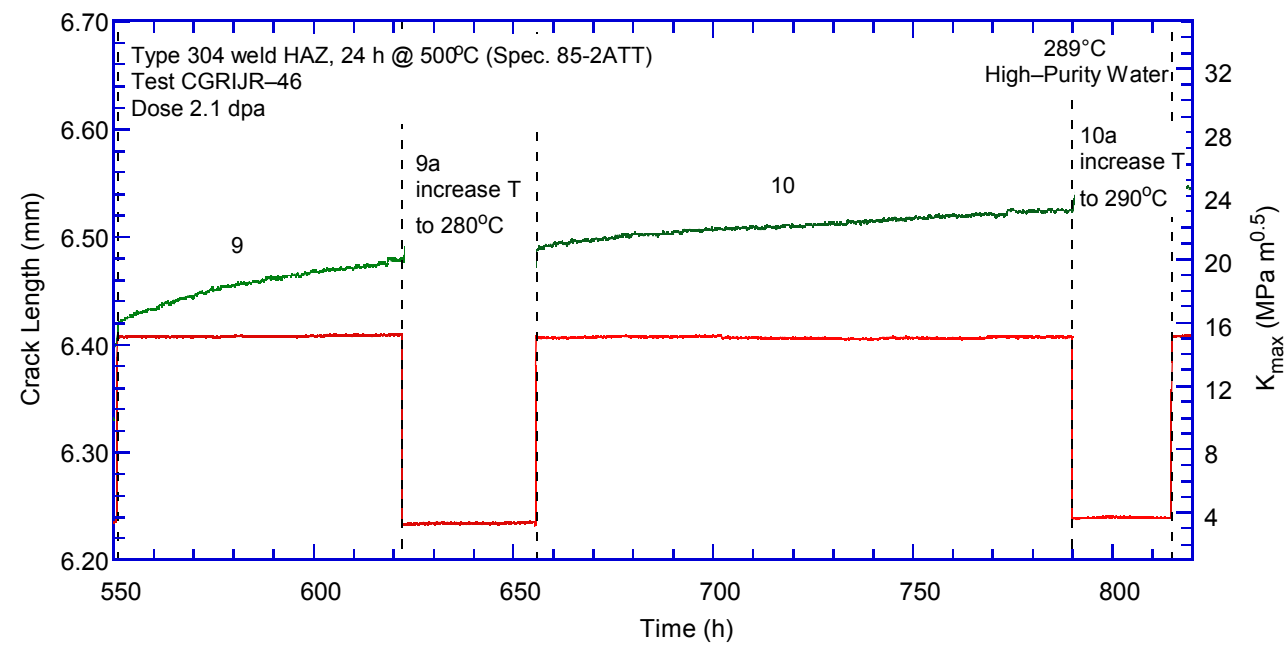

(c)

Figure 19. Crack-length-vs.-time plot for the thermally treated Type 304 SMA HAZ specimen (85-2ATT, $\sim 2 \mathrm{dpa}$ ) in BWR water at $289^{\circ} \mathrm{C}$. 


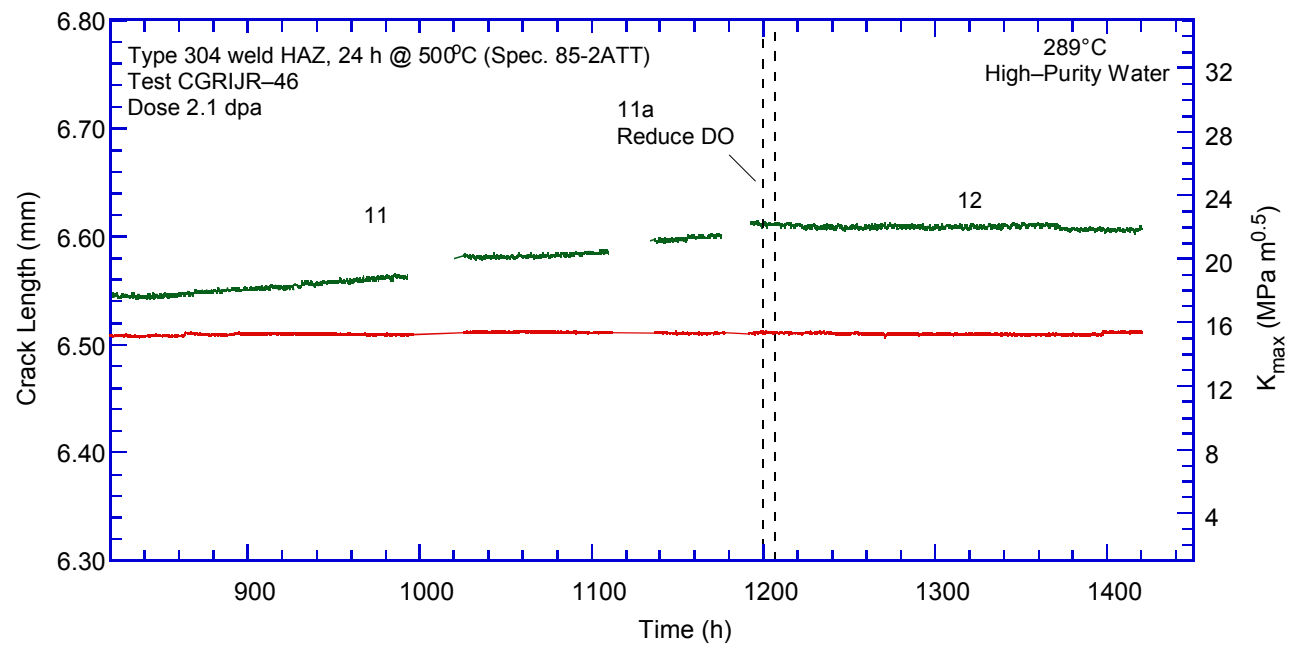

(d)

Figure 19. (Contd.)

Figures 20 and 21 show the cyclic and constant-load CGRs obtained from this HAZ specimen. For the cyclic CGR test, environmentally enhanced cracking was evident at about $10^{-10} \mathrm{~m} / \mathrm{s}$. The influence of environment on cyclic CGR increased rapidly with the increasing rise time. For the constant-load CGR test, the CGRs at $\approx 290^{\circ} \mathrm{C}$ were about eight times higher than the NUREG-0313 curve. The CGRs obtained at $270^{\circ} \mathrm{C}$ and $280^{\circ} \mathrm{C}$ were significantly lower. No measurable crack extension was observed in the constant-load CGR test at $290^{\circ} \mathrm{C}$ in HWC.

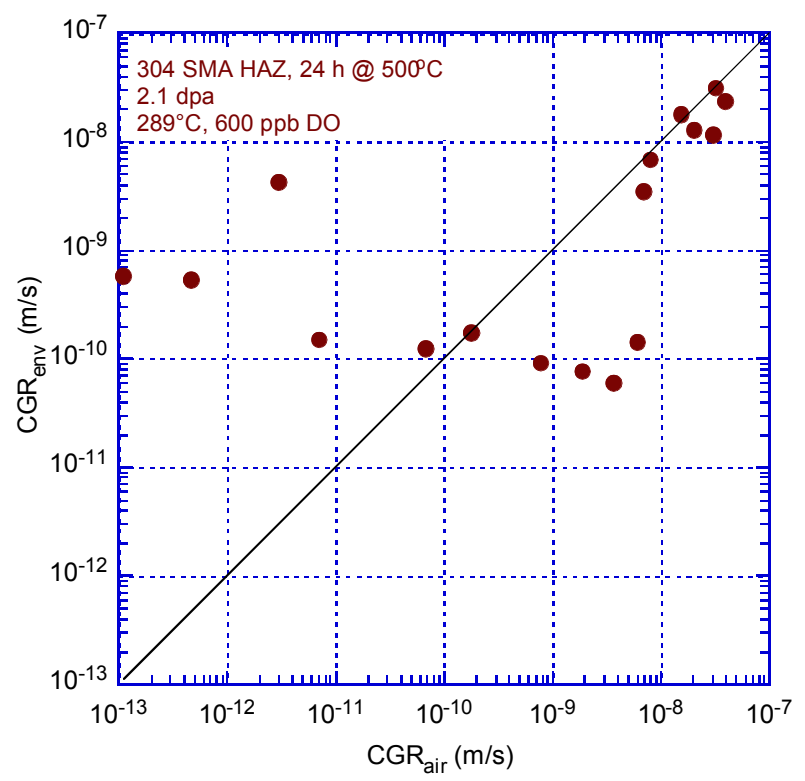

Figure 20. Cyclic CGRs for the thermally treated Type 304 SS SMA weld HAZ specimen (85-2ATT) irradiated to $2.1 \mathrm{dpa}$. 


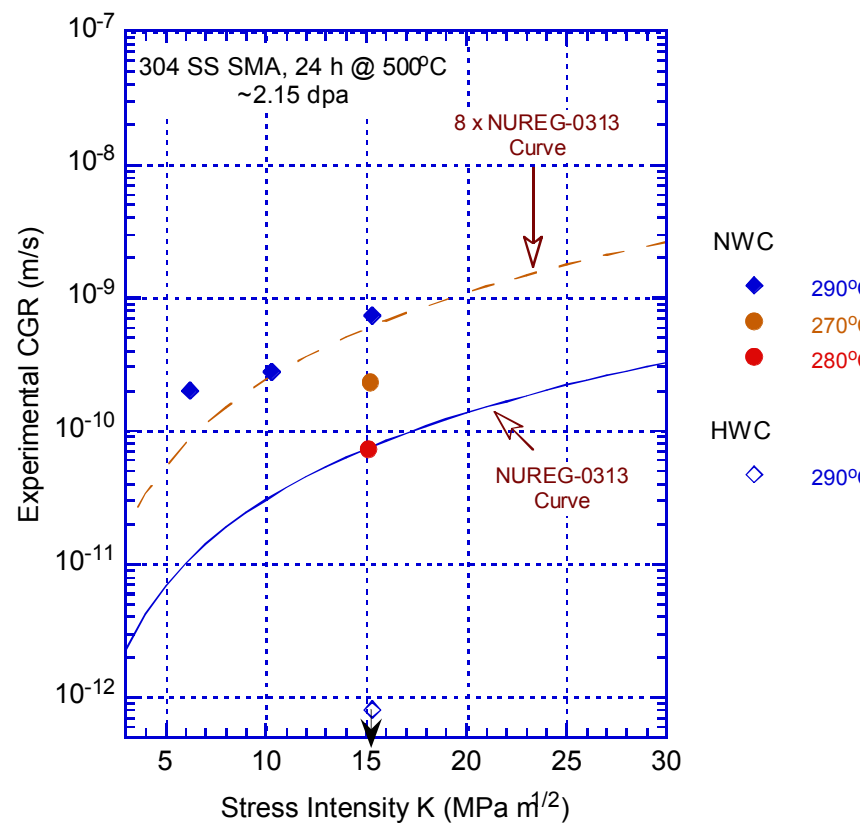

Figure 21. Constant-load CGRs for the thermally treated Type 304 SS SMA weld HAZ specimen (85-2ATT) irradiated to 2.1 dpa.

A fracture toughness J-R test was performed on the specimen in NWC after the CGR test. The J-R test was conducted at a constant extension rate of $0.43 \mu \mathrm{m} / \mathrm{s}$. During the test, loading was interrupted periodically and crack extension was measured by the DCPD method. A 30-s relaxation time was allowed prior to each DCPD measurement. Figure 22 shows the load vs. load-line displacement curve and the J-R data. A power-law curve fitting on the J-R result yielded a $\mathrm{J}_{\mathrm{IC}}$ of about $34 \mathrm{~kJ} / \mathrm{m}^{2}$ (Fig. 22b).

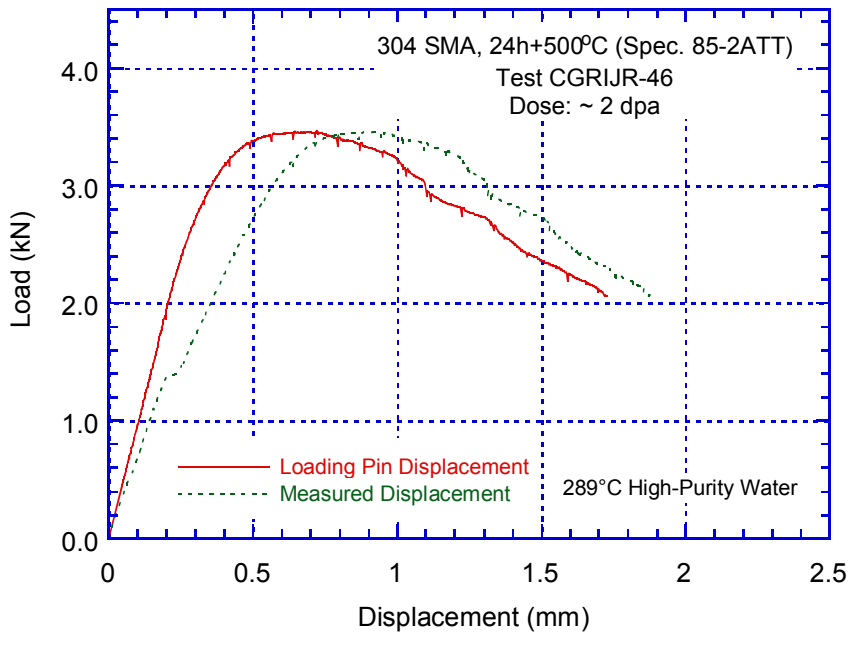

(a)

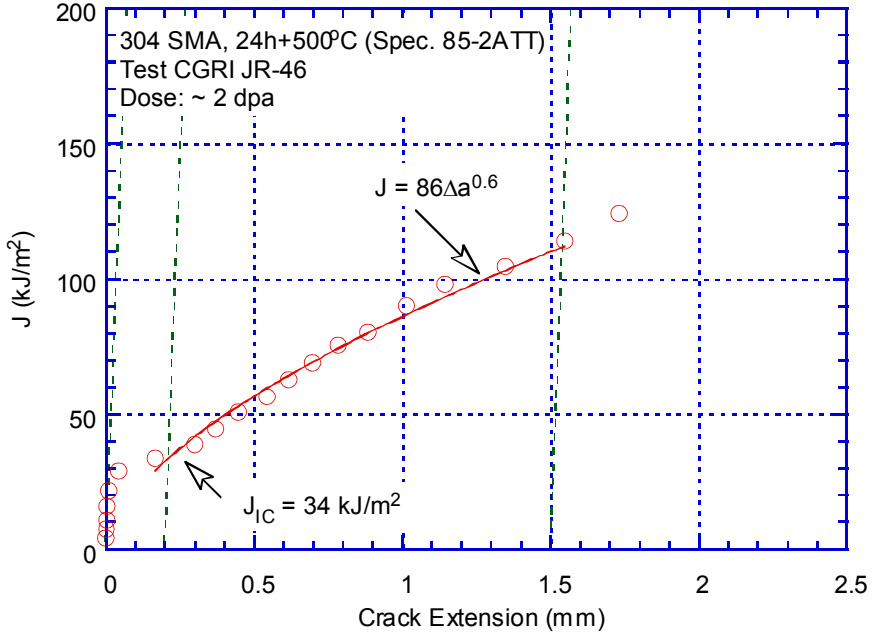

(b)

Figure 22. (a) Load vs. load-line displacement and (b) fracture toughness J-R curve for the thermally treated 304 SMA weld HAZ specimen (85-2ATT).

After the J-R test, the specimen was fatigued at room temperature in air to mark the final crack front. The specimen was then fractured, and optical images of the fracture surface were taken. The final crack length measured on the fracture surface was approximately $11 \%$ greater than the value determined previously by the DCPD method. Accordingly, the crack extension results obtained from DCPT measurement were scaled proportionately. As shown in Fig. 23, an out-of-plane crack propagation had 
occurred during the J-R test. The complex weld microstructure along the fusion line may have contributed to the out-of-plane crack propagation.

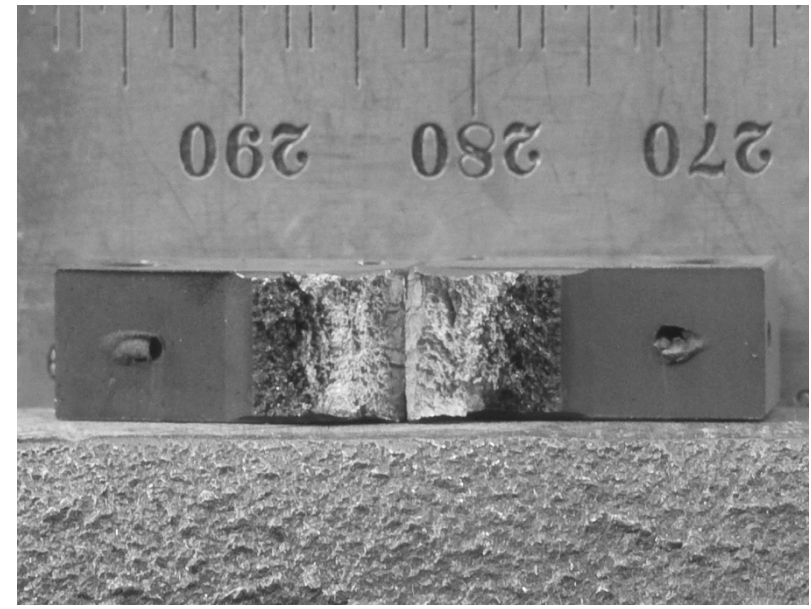

(a)

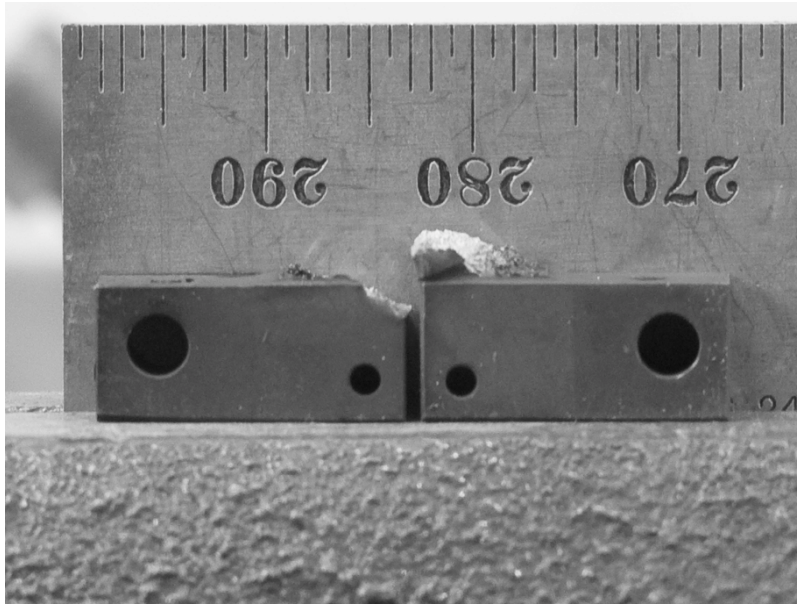

(b)

Figure 23. Optical images of the thermally treated 304 SS SMA HAZ specimen (85-2ATT) After fracturing: (a) fracture surface and (b) side view. 


\subsection{Sensitized Type 304 SS Irradiated to 0.75 dpa}

\subsubsection{Type $304 \mathrm{SS}$ Sensitized at $600^{\circ} \mathrm{C}$ for $10.5 \mathrm{~h}(85-1 \mathrm{TT})$}

A CGR test was performed on a Type $304 \mathrm{SS}$ specimen sensitized at $600^{\circ} \mathrm{C}$ for $10.5 \mathrm{~h}$ (Specimen 85-1TT). The objective of this test was to investigate the effect of sensitization on IASC susceptibility around "threshold" dose level. The specimen was irradiated to $0.75 \mathrm{dpa}$ at $\approx 290^{\circ} \mathrm{C}$ in the Halden reactor. The test was started in high-purity water with $\approx 350 \mathrm{ppb}$ DO and a flow rate of $\approx 20 \mathrm{~mL} / \mathrm{min}$. The specimen was fatigue precracked at $\mathrm{R}=0.25, \mathrm{Kmax}=18.0 \mathrm{MPa} \mathrm{m}{ }^{1 / 2}$, triangular waveform, and $2-\mathrm{Hz}$ frequency. After $130-\mu \mathrm{m}$ crack advance, $\mathrm{R}$ was increased incrementally to 0.7 , and the waveform was changed to a slow/fast sawtooth with rise times of 300 or $1000 \mathrm{~s}$ and a return time of $12 \mathrm{~s}$. The test conditions and results are summarized in Table 8, and the crack-extension-vs.-time plots are shown in Fig. 24. Environmental enhancement started to appear during period 2 at $\approx 70 \mathrm{~h}$ test duration (Fig. 24a). Environmental effects on CGR are more evident in the subsequent test stages. Figure 25 summarizes cyclic CGR results on this specimen.

Table 8. Test results for a Type 304 specimen sensitized at $600^{\circ} \mathrm{C}$ for $10.5 \mathrm{~h}(85-1 \mathrm{TT}, 0.75 \mathrm{dpa})$ in BWR water.

\begin{tabular}{|c|c|c|c|c|c|c|c|c|c|c|c|c|c|c|}
\hline \multirow{2}{*}{$\begin{array}{c}\text { Test } \\
\text { Period }\end{array}$} & \multirow{2}{*}{$\begin{array}{c}\text { Test } \\
\text { Time, } \\
\mathrm{h}\end{array}$} & \multirow{2}{*}{$\begin{array}{c}\text { Test } \\
\text { Temp., } \\
{ }^{\circ} \mathrm{C}\end{array}$} & \multicolumn{2}{|c|}{$\begin{array}{c}\text { ECP }^{\mathrm{a}} \\
\mathrm{mV}(\mathrm{SHE})\end{array}$} & \multirow{2}{*}{$\begin{array}{c}\mathrm{O}_{2} \\
\text { Conc., } \\
\text { ppb }\end{array}$} & \multirow{2}{*}{$\begin{array}{c}\text { R } \\
\text { Load } \\
\text { Ratio } \\
\end{array}$} & \multirow{2}{*}{$\begin{array}{c}\text { Rise } \\
\text { Time, } \\
\mathrm{s} \\
\end{array}$} & \multirow{2}{*}{$\begin{array}{c}\text { Return } \\
\text { Time, } \\
\mathrm{s}\end{array}$} & \multirow{2}{*}{$\begin{array}{c}\text { Hold } \\
\text { Time, } \\
\text { s }\end{array}$} & \multirow{2}{*}{$\begin{array}{c}\mathrm{K}_{\max } \\
\mathrm{MPa} \mathrm{m}^{1 / 2}\end{array}$} & \multirow{2}{*}{$\begin{array}{c}\Delta \mathrm{K}, \\
\mathrm{MPa} \mathrm{m}{ }^{1 / 2}\end{array}$} & \multirow{2}{*}{$\begin{array}{c}\text { CGR in } \\
\text { Env., } \\
\mathrm{m} / \mathrm{s}\end{array}$} & \multirow{2}{*}{$\begin{array}{c}\text { CGR in } \\
\text { Air, } \\
\mathrm{m} / \mathrm{s}\end{array}$} & \multirow{2}{*}{$\begin{array}{c}\text { Crack } \\
\text { Length, } \\
\mathrm{mm}\end{array}$} \\
\hline & & & $\mathrm{Pt}$ & Steel & & & & & & & & & & \\
\hline & & & & & & & & & & & & & & 5.804 \\
\hline Pre & 30 & 288 & - & - & 350 & 0.25 & 0.22 & 0.22 & $0.03 / 0.03$ & 18.0 & 13.5 & $9.43 \mathrm{E}-8$ & $1.21 \mathrm{E}-7$ & 5.964 \\
\hline $1 \mathrm{a}$ & 38 & 288 & - & - & 350 & 0.51 & 8.1 & 1.6 & $1.9 / 0.4$ & 17.3 & 8.4 & 4.99E-10 & $9.29 \mathrm{E}-10$ & 5.976 \\
\hline $1 \mathrm{~b}$ & 48 & 286 & - & - & 350 & 0.52 & 8.1 & 1.6 & $1.9 / 0.4$ & 17.3 & 8.4 & negligible & $9.12 \mathrm{E}-10$ & 5.976 \\
\hline 2 & 56 & 286 & - & - & 350 & 0.42 & 4.2 & 0.8 & $0.8 / 0.2$ & 17.5 & 10.2 & 4.93E-09 & $3.00 \mathrm{E}-09$ & 6.057 \\
\hline 3 & 120 & 286 & - & - & 350 & 0.56 & 235 & 9.4 & $65 / 2.6$ & 17.3 & 7.6 & $8.44 \mathrm{E}-10$ & $2.37 \mathrm{E}-11$ & 6.167 \\
\hline 4 & 175 & 287 & - & - & 350 & 0.75 & 674 & 8.1 & $326 / 3.9$ & 17.6 & 4.5 & $4.63 \mathrm{E}-10$ & $1.66 \mathrm{E}-12$ & 6.226 \\
\hline 5 & 288 & 287 & - & - & 350 & 1.0 & - & - & - & 17.9 & - & $2.19 \mathrm{E}-10$ & - & 6.315 \\
\hline 6 & 456 & 287 & - & - & 350 & 1.0 & - & - & - & 16.3 & - & $1.51 \mathrm{E}-10$ & - & 6.417 \\
\hline 7 & 504 & 287 & 275 & 230 & 350 & 1.0 & - & - & - & 20.4 & - & $2.89 \mathrm{E}-10$ & - & 6.467 \\
\hline
\end{tabular}

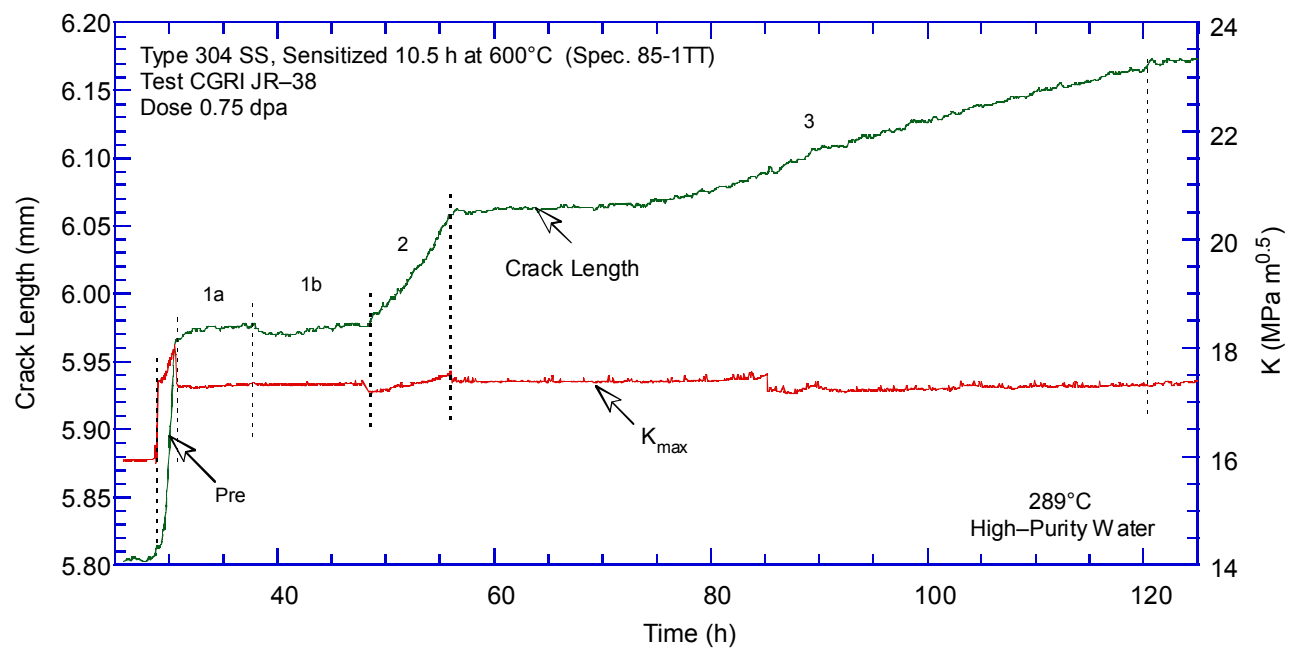

(a)

Figure 24. Crack-length-vs.-time plot for the Type $304 \mathrm{SS}$ specimen sensitized at $600^{\circ} \mathrm{C}$ for $10.5 \mathrm{~h}$ (85-1TT, $\sim 0.75 \mathrm{dpa}$ ) in BWR water at $289^{\circ} \mathrm{C}$. 


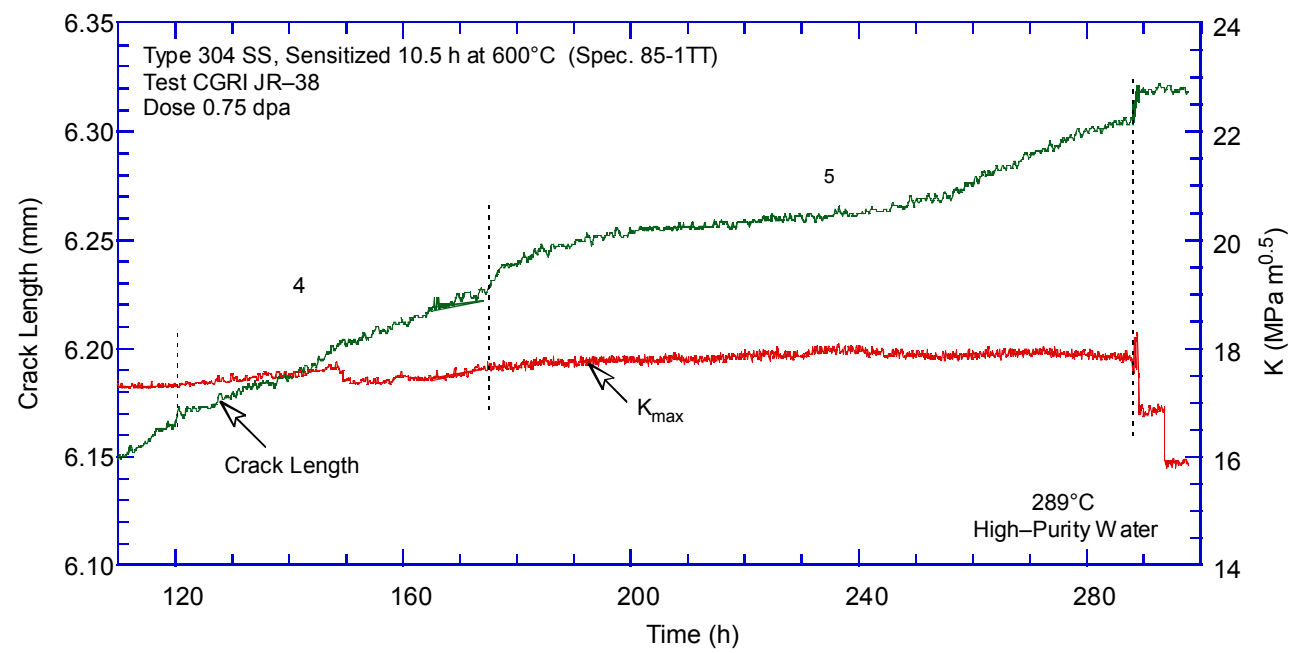

(b)

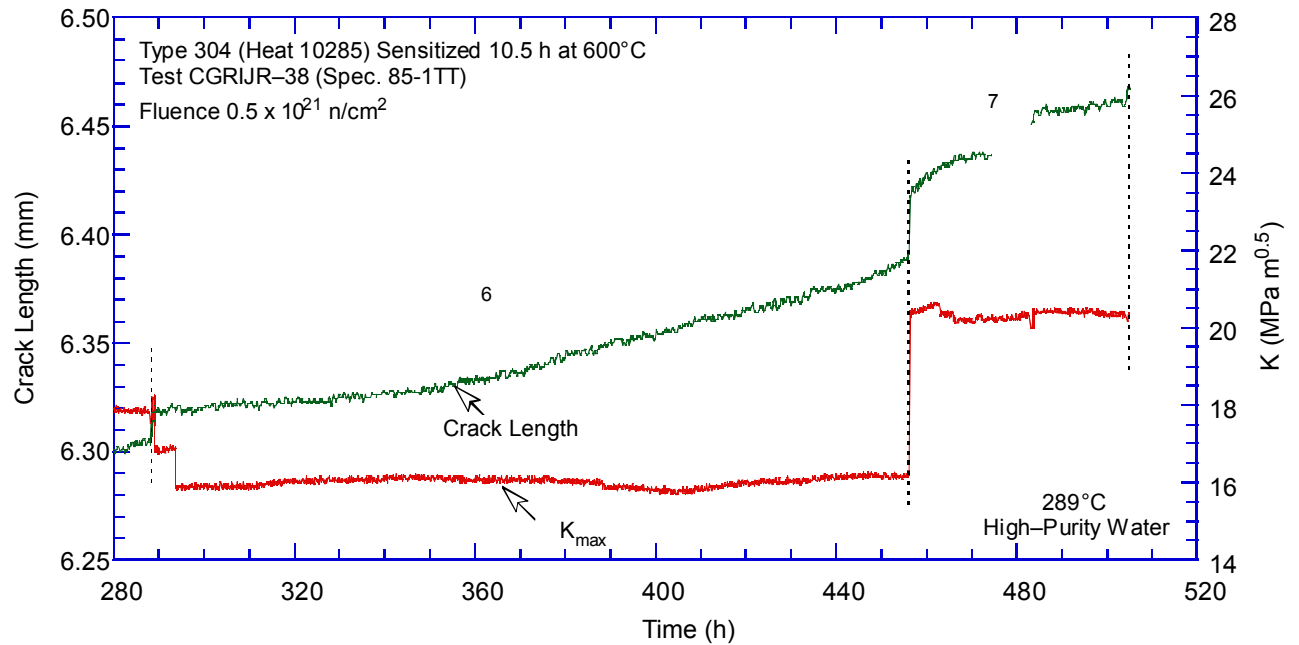

Figure 24. (Contd.)

(c) 


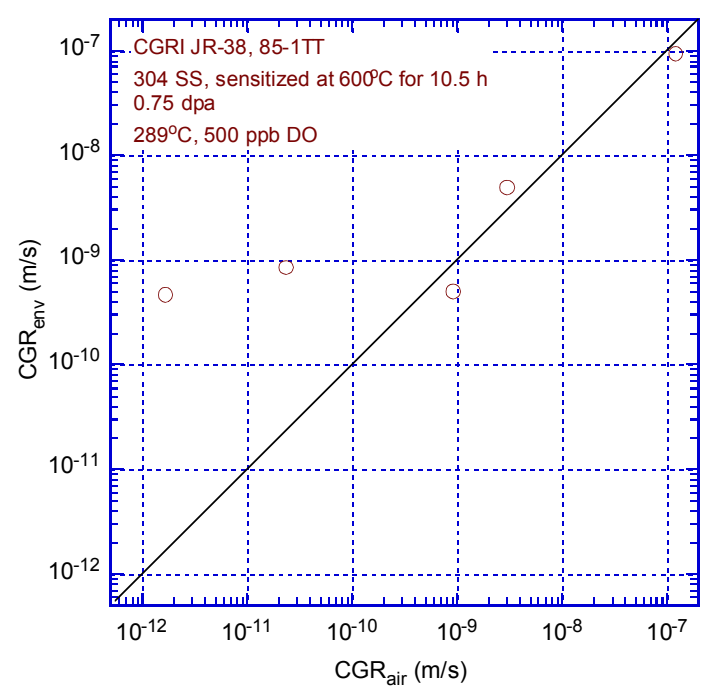

Figure 25. Cyclic CGR for the Type 304 specimen sensitized at $600^{\circ} \mathrm{C}$ for $10.5 \mathrm{~h}(85-1 \mathrm{TT})$ and irradiated to $0.75 \mathrm{dpa}$.

Starting from test period 5, the specimen was subjected to constant load with $\mathrm{Kmax}=$ 17.6 $\mathrm{MPa} \mathrm{m} \mathrm{m}^{1 / 2}$. After $\approx 100 \mathrm{~h}, \mathrm{Kmax}$ was decreased to $15.8 \mathrm{MPa} \mathrm{m}^{1 / 2}$. After another $\approx 170 \mathrm{~h}$, Kmax was increased to $19.7 \mathrm{MPa} \mathrm{m}{ }^{1 / 2}$. The CGR test was terminated at $504 \mathrm{~h}$. Figure 26 shows the CGR results under constant loading, and the NUREG-0313 curve is also plotted for reference.

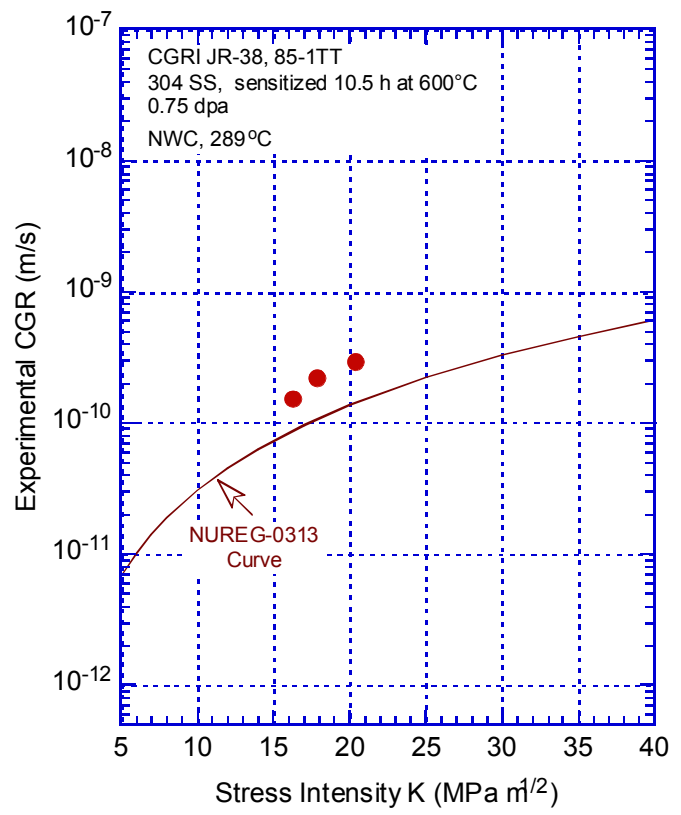

Figure 26. Crack growth rate versus stress intensity under constant-loading conditions for the Type 304 specimen sensitized at $600^{\circ} \mathrm{C}$ for $10.5 \mathrm{~h}$ (85-1TT) and irradiated to $0.75 \mathrm{dpa}$.

After the CGR test, a J-R curve test was performed on the specimen at $289^{\circ} \mathrm{C}$ in $\mathrm{NWC}(\approx 350 \mathrm{ppb}$ DO). The test was conducted at a constant extension rate of $0.43 \mu \mathrm{m} / \mathrm{s}$; the DC potential drop method was used to measure crack extension. The load vs. load-line displacement curve is shown in Fig. 27. The J-R data were analyzed to obtain a power-law curve for the material. The DC potential data were corrected to account for the effects of plasticity on the measured potential. The fracture toughness J-R curve for Specimen 85-1TT in NWC is shown in Fig. 28, and the $\mathrm{J}_{\mathrm{Q}}{ }^{*}$ is $182 \mathrm{~kJ} / \mathrm{m}^{2}$.

* A provisional value of $\mathrm{J}_{\mathrm{IC}}$. 

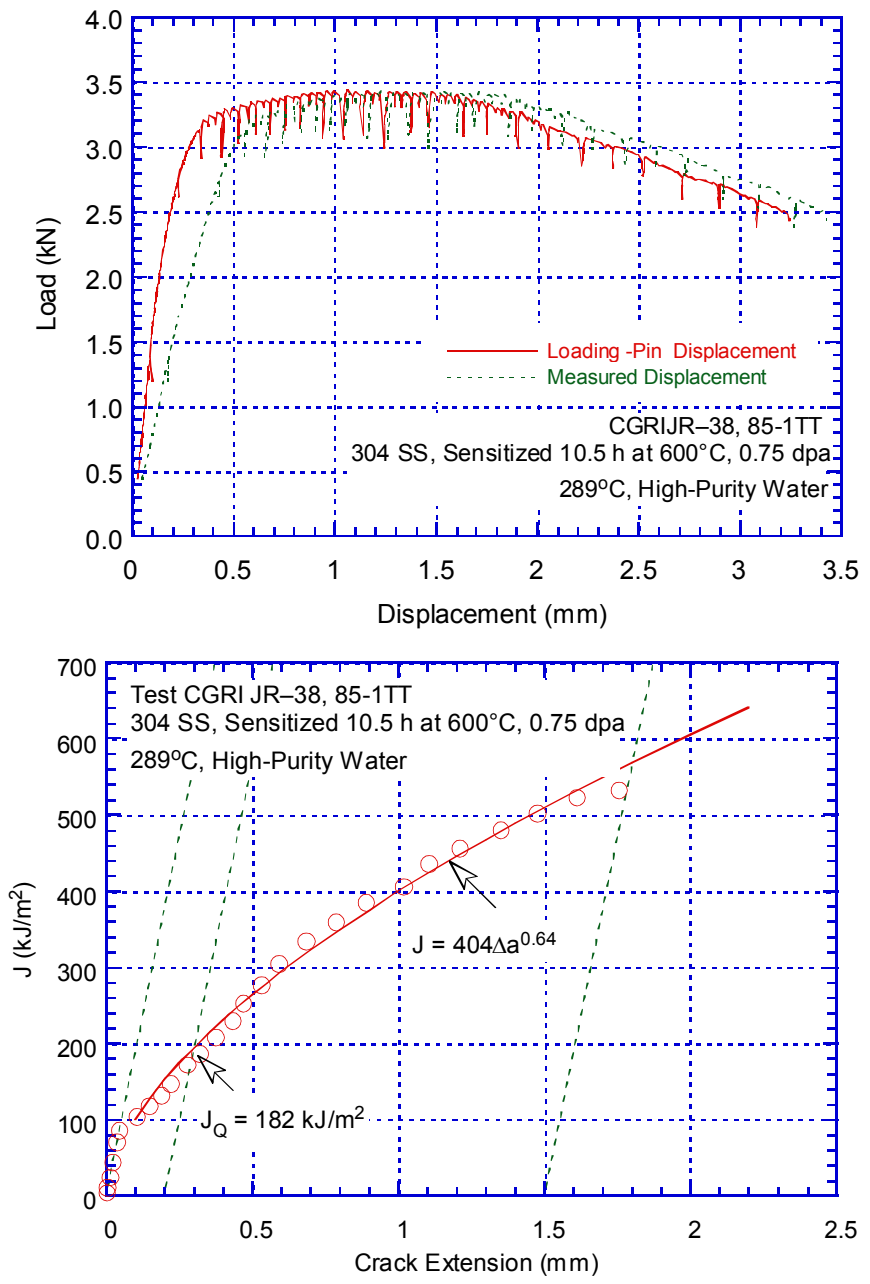

Figure 27. Load vs. load-line displacement curve for the Type 304 specimen sensitized at $600^{\circ} \mathrm{C}$ for $10.5 \mathrm{~h}(85-1 \mathrm{TT})$ and tested in NWC at $289^{\circ} \mathrm{C}$.
Figure 28. Fracture toughness $\mathrm{J}-\mathrm{R}$ curve for the Type 304 specimen sensitized at $600^{\circ} \mathrm{C}$ for $10.5 \mathrm{~h}(85-1 \mathrm{TT})$ and tested in NWC at $289^{\circ} \mathrm{C}$.

The final crack front was marked by fatigue cycling at room temperature after the J-R test. Specimen 85-1TT was then fractured, and the final crack length of both halves of the fractured specimen was measured from the photograph of the fracture surface (Fig. 29). The actual crack extension was $\approx 24 \%$ greater than the value determined from the DC potential measurements. The crack extensions estimated from the DC potential method were adjusted accordingly. 


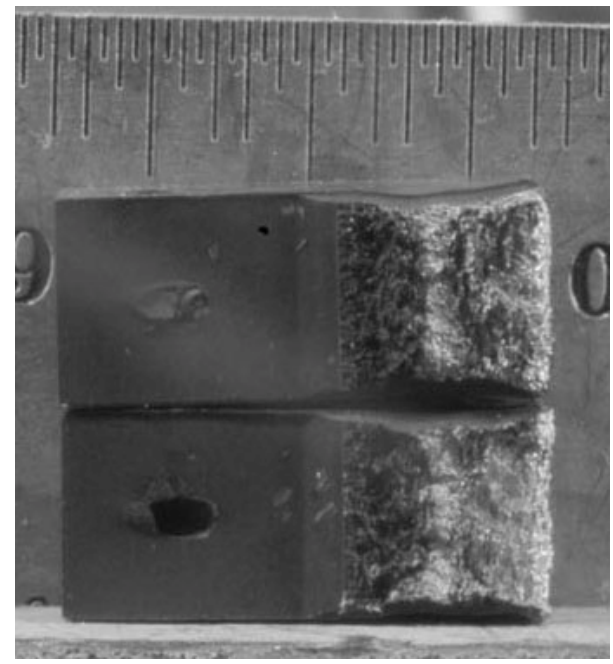

Figure 29. Photograph of the fracture surface of the Type 304 specimen sensitized at $600^{\circ} \mathrm{C}$ for $10.5 \mathrm{~h}(85-1 \mathrm{TT})$ and irradiated to $0.75 \mathrm{dpa}$.

\subsubsection{Type $304 \mathrm{SS}$ Sensitized at $600^{\circ} \mathrm{C}$ for $24 \mathrm{~h}$ (85-5A1TT)}

A CGR test was performed in simulated BWR environment on a sensitized Type 304 SS specimen irradiated to $\approx 0.75 \mathrm{dpa}$ at $\approx 290^{\circ} \mathrm{C}(85-5 \mathrm{~A} 1 \mathrm{TT})$. The specimen was sensitized at $600^{\circ} \mathrm{C}$ for $24 \mathrm{~h}$ prior to irradiation. The objective of this test was to compare with the previous test (85-1TT) to evaluate IASCC susceptibility at a higher degree of sensitization. Table 9 shows all test conditions and CGR results of this specimen, and Fig. 30 is the crack-length-vs.-time plot of this test.

Table 9. Test results for a Type 304 specimen sensitized at $600^{\circ} \mathrm{C}$ for $24 \mathrm{~h}(85-5 \mathrm{~A} 1 \mathrm{TT}, 0.75 \mathrm{dpa})$ in BWR water.

\begin{tabular}{|c|c|c|c|c|c|c|c|c|c|c|c|c|c|c|}
\hline \multirow{2}{*}{$\begin{array}{c}\text { Test } \\
\text { Period }\end{array}$} & \multirow{2}{*}{$\begin{array}{c}\text { Test } \\
\text { Time, } \\
\mathrm{h}\end{array}$} & \multirow{2}{*}{$\begin{array}{c}\text { Test } \\
\text { Temp., } \\
{ }^{\circ} \mathrm{C}\end{array}$} & \multicolumn{2}{|c|}{$\begin{array}{c}\mathrm{ECP}^{\mathrm{a}} \\
\mathrm{mV}(\mathrm{SHE}) \\
\end{array}$} & \multirow{2}{*}{$\begin{array}{c}\mathrm{O}_{2} \\
\text { Conc., } \\
\text { ppb }\end{array}$} & \multirow{2}{*}{$\begin{array}{c}\text { R } \\
\text { Load } \\
\text { Ratio }\end{array}$} & \multirow{2}{*}{$\begin{array}{c}\text { Rise } \\
\text { Time, } \\
\mathrm{S} \\
\end{array}$} & \multirow{2}{*}{$\begin{array}{c}\text { Return } \\
\text { Time, } \\
\text { s }\end{array}$} & \multirow{2}{*}{$\begin{array}{c}\text { Hold } \\
\text { Time }^{\mathrm{b}} \\
\mathrm{s}\end{array}$} & \multirow{2}{*}{$\begin{array}{c}\mathrm{K}_{\max }, \\
\mathrm{MPa} \mathrm{m}^{1 / 2}\end{array}$} & \multirow{2}{*}{$\begin{array}{c}\Delta \mathrm{K}, \\
\mathrm{MPa} \mathrm{m}^{1 / 2}\end{array}$} & \multirow{2}{*}{$\begin{array}{c}\text { CGR in } \\
\text { Env., } \\
\text { m/s }\end{array}$} & \multirow{2}{*}{$\begin{array}{c}\text { CGR in } \\
\text { Air, } \\
\mathrm{m} / \mathrm{s}\end{array}$} & \multirow{2}{*}{$\begin{array}{c}\text { Crack } \\
\text { Length, } \\
\mathrm{mm}\end{array}$} \\
\hline & & & $\mathrm{Pt}$ & Steel & & & & & & & & & & \\
\hline & & & & & & & & & & & & & & 5.860 \\
\hline Pre & 4 & 291 & 294 & 232 & 700 & 0.30 & 0.90 & 0.90 & $0.10 / 0.10$ & 17.3 & 12.0 & $1.79 \mathrm{E}-8$ & $2.16 \mathrm{E}-8$ & 5.935 \\
\hline $1 \mathrm{a}$ & 6 & 291 & 291 & 231 & 700 & 0.52 & 0.86 & 0.86 & $0.14 / 0.14$ & 17.0 & 8.2 & $1.11 \mathrm{E}-8$ & 7.99E-9 & 5.975 \\
\hline $1 b$ & 10 & 291 & 291 & 231 & 700 & 0.50 & 0.85 & 0.85 & $0.15 / 0.15$ & 15.0 & 7.5 & 4.93E-9 & 5.88E-9 & 5.999 \\
\hline $1 \mathrm{c}$ & 21 & 291 & 293 & 233 & 700 & 0.50 & 8.53 & 8.53 & $1.47 / 1.47$ & 15.1 & 7.6 & $1.87 \mathrm{E}-9$ & $6.02 \mathrm{E}-10$ & 6.031 \\
\hline $1 d$ & 29 & 290 & & & 700 & 0.50 & 25.6 & 10.2 & $4.4 / 1.8$ & 15.1 & 7.6 & $8.69 \mathrm{E}-10$ & $2.05 \mathrm{E}-10$ & 6.043 \\
\hline $2 \mathrm{a}$ & 33 & 290 & & & 700 & 0.70 & 23.2 & 9.30 & $6.7 / 2.7$ & 15.0 & 4.5 & $1.10 \mathrm{E}-9$ & $4.82 \mathrm{E}-11$ & 6.053 \\
\hline $2 b$ & 45 & 290 & & & 700 & 0.70 & 223 & 9.33 & $76.7 / 2.7$ & 15.1 & 4.6 & $6.13 \mathrm{E}-10$ & $5.09 \mathrm{E}-12$ & 6.071 \\
\hline $2 c$ & 68 & 290 & & & 700 & 0.70 & 777 & 9.32 & $223 / 2.7$ & 15.1 & 4.6 & $3.17 \mathrm{E}-10$ & $1.53 \mathrm{E}-12$ & 6.092 \\
\hline 3 & 126 & 290 & 285 & 223 & 700 & 1.0 & - & - & - & 15.4 & - & $1.34 \mathrm{E}-10$ & - & 6.142 \\
\hline 4 & 173 & 290 & 289 & 228 & 700 & 1.0 & - & - & - & 10.3 & - & negligible & - & 6.124 \\
\hline 5 & 341 & 290 & 281 & 227 & 700 & 1.0 & - & - & - & 18.2 & - & $8.16 \mathrm{E}-11$ & - & 6.192 \\
\hline 6 & 480 & 290 & 281 & 233 & 700 & 1.0 & - & - & - & 10.3 & - & $6.25 \mathrm{E}-11$ & - & 6.215 \\
\hline 7 & 549 & 290 & -495 & -240 & 20 & 1.0 & - & - & - & 10.2 & - & negligible & - & 6.209 \\
\hline 8 & 651 & 290 & & & 20 & 1.0 & - & - & - & 15.5 & - & negligible & - & 6.236 \\
\hline 9 & 838 & 290 & -414 & -413 & 20 & 1.0 & - & - & - & 17.5 & - & negligible & - & 6.241 \\
\hline $9 \mathrm{a}$ & 960 & Increase & & & & - & - & - & - & 17.5 & - & negligible & - & 6.269 \\
\hline 10 & 1197 & 290 & 270 & 216 & 600 & 1.0 & - & - & - & 17.5 & - & $3.65 \mathrm{E}-11^{\mathrm{c}}$ & - & 6.315 \\
\hline $10 \mathrm{a}$ & 1223 & Reduce & mperat & & & 1.0 & - & - & - & 17.6 & - & 4.64E-10 & - & 6.350 \\
\hline 11 & 1390 & 272 & 292 & 232 & 600 & 1.0 & - & - & - & 17.7 & - & $5.70 \mathrm{E}-11$ & - & 6.385 \\
\hline
\end{tabular}




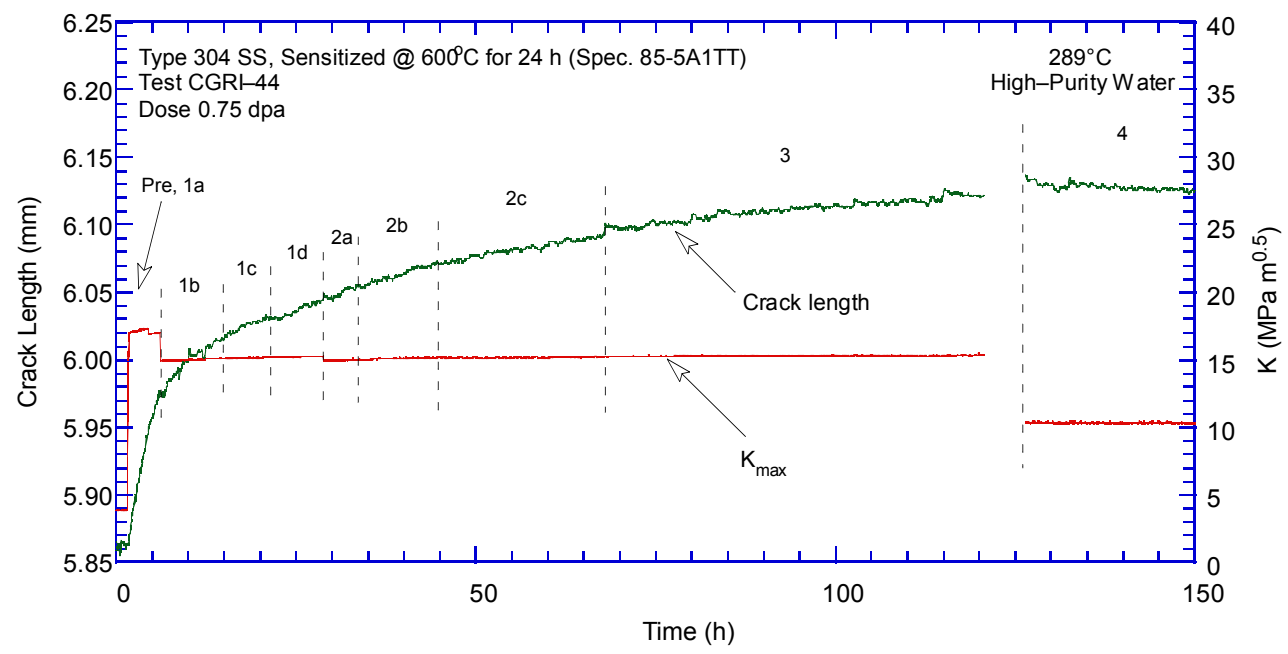

(a)

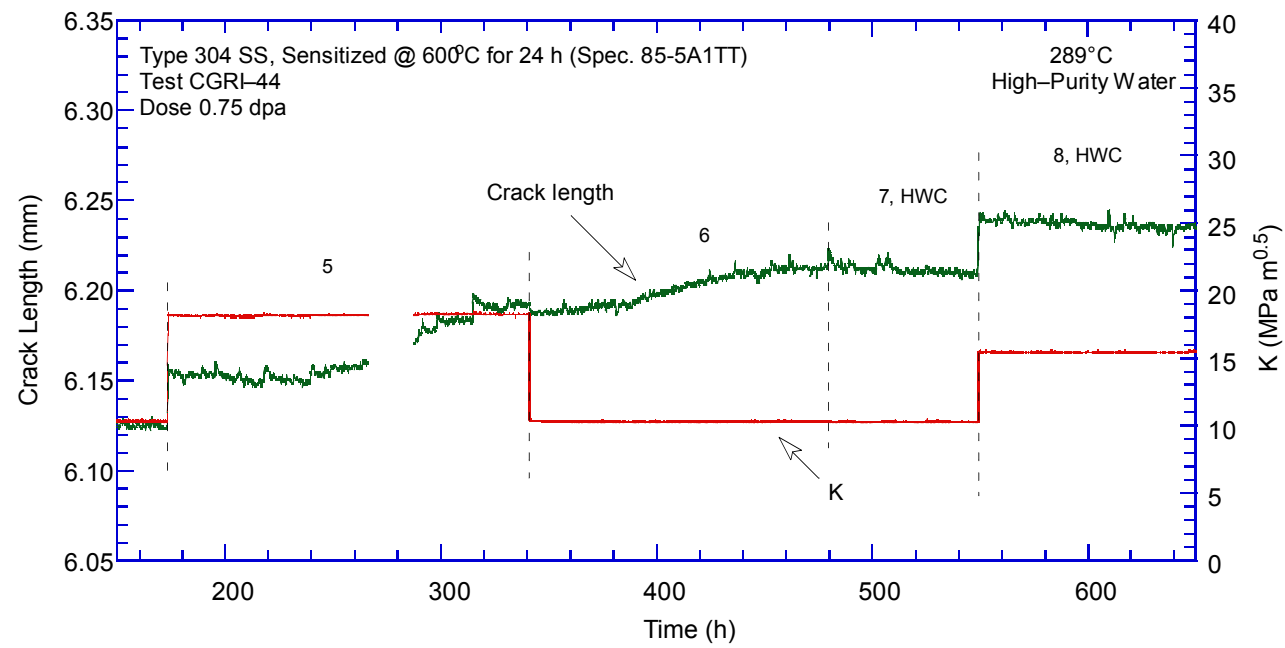

(b)

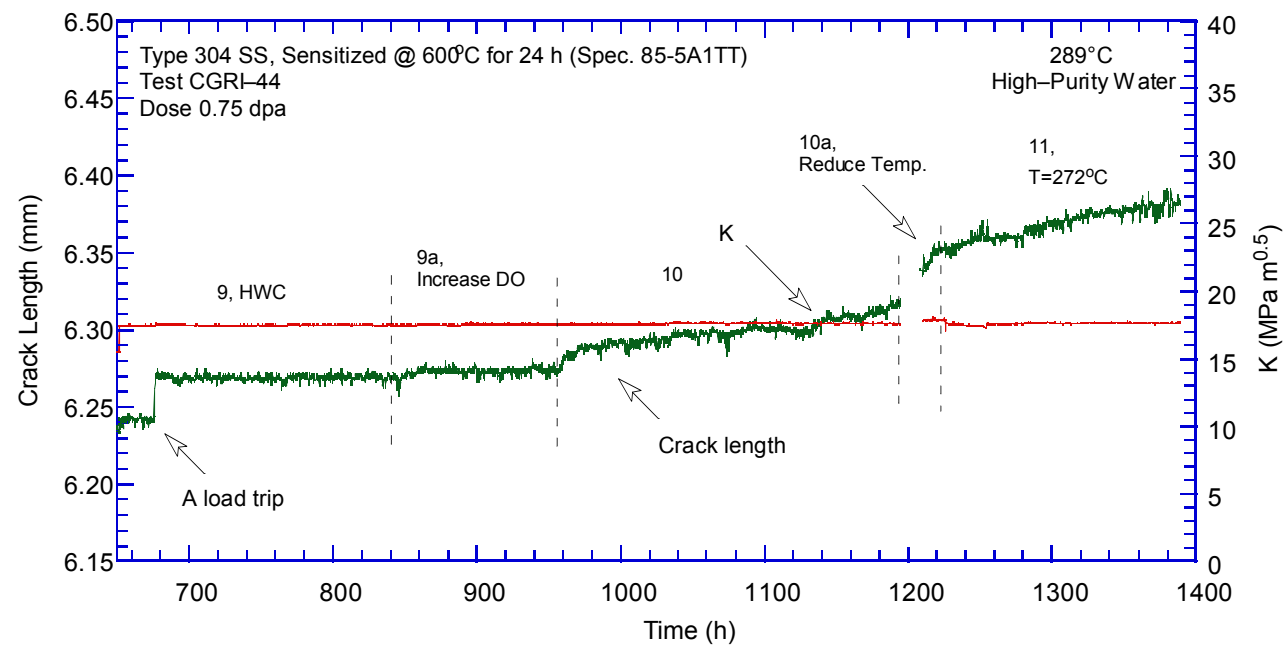

(c)

Figure 30. Crack-length-vs.-time plot for the Type $304 \mathrm{SS}$ specimen sensitized at $600^{\circ} \mathrm{C}$ for $24 \mathrm{~h}$ (85-5A1TT, $\sim 0.75 \mathrm{dpa})$ in BWR water. 
The specimen was first exposed to high-purity water with $600 \mathrm{ppb}$ DO for over $70 \mathrm{~h}$ before the test. After the environmental condition was stabilized, fatigue precracking was initiated with a triangular waveform at $\mathrm{R}=0.3, \mathrm{Kmax}=17 \mathrm{MPa} \mathrm{m}{ }^{1 / 2}$, and $0.5-\mathrm{Hz}$ frequency. After $\approx 70-\mu \mathrm{m}$ crack advance, the load ratio was increased to 0.5 , and the $\mathrm{Kmax}$ was reduced to $\approx 15 \mathrm{MPa} \mathrm{m}^{1 / 2}$. Environmentally enhanced cracking was readily achieved in this sensitized specimen. After about $170-\mu \mathrm{m}$ crack advance, the triangular waveform was replaced by slow/fast sawtooth loading, and the load ratio was further increased to 0.7 . With additional $\approx 60-\mu \mathrm{m}$ crack extension, the test condition was switched to a constant load at test period 3 .

The constant-load CGR is about $\approx 1.34 \times 10^{-10} \mathrm{~m} / \mathrm{s}$ for test period 3 at $\mathrm{K} \approx 15 \mathrm{MPa} \mathrm{m}^{1 / 2}$. An unexpected overload caused by a load trip occurred at the end of test period 3. Subsequently, no crack extension was observed during test period 4 at $\mathrm{K} \approx 10 \mathrm{MPa} \mathrm{m}^{1 / 2}$ even with periodical unloading. To reestablish crack growth, a higher $\mathrm{K}$ value was applied on the specimen in test period 5 . After about $50 \mathrm{~h}$ and several loading and unloading cycles, crack extension was re-activated, and an average CGR of $8.16 \times 10^{-11} \mathrm{~m} / \mathrm{s}$ was registered at $\mathrm{K} \approx 18 \mathrm{MPa} \mathrm{m}{ }^{1 / 2}$ for test period 5 . An average CGR of $6.25 \times 10^{-11} \mathrm{~m} / \mathrm{s}$ was also recorded in test period 6 for $\mathrm{K} \approx 10 \mathrm{MPa} \mathrm{m}^{1 / 2}$.

A constant-load CGR test was also carried out in HWC on this sensitized specimen. No crack extension was detectable in HWC for stress levels of 10,15 , and $17 \mathrm{MPa} \mathrm{m}{ }^{1 / 2}$. Following the CGR test in HWC, the DO level in the system was recovered to NWC during test period 9a. Test period 10 was used to re-establish the CGR observed during the earlier test periods under NWC. Once a comparable CGR was achieved, the autoclave temperature was reduced to prepare for a test at a lower temperature. In test period 11 , the CGR was measured at $\approx 270^{\circ} \mathrm{C}$ and $\mathrm{K} \approx 17.7 \mathrm{MPa} \mathrm{m}{ }^{1 / 2}$. All constant-load CGR results are plotted in Fig. 32.

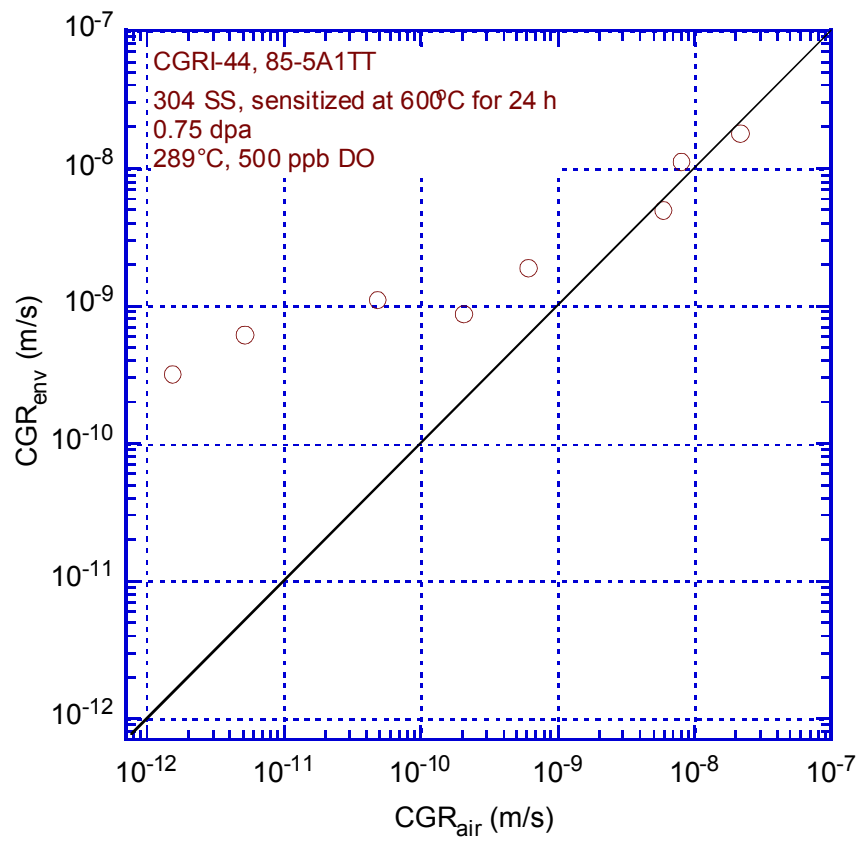

Figure 31. Cyclic CGR for the Type 304 specimen sensitized at $600^{\circ} \mathrm{C}$ for $24 \mathrm{~h}(85-$ $5 \mathrm{~A} 1 \mathrm{TT})$ and irradiated to $0.75 \mathrm{dpa}$.

After the CGR test, a DCPD pin was found broken in the subsequent J-R test. The J-R test had to be terminated. Before the specimen was pulled open, the final crack front was marked by fatigue cycling at room temperature. The actual crack length of both halves of the fractured specimen was measured from the photograph of the fracture surface (Fig. 33). The crack extension was $\approx 8 \%$ greater than the 
value determined from the DC potential measurements. Accordingly, the crack extensions estimated from the DC potential method were adjusted proportionally.

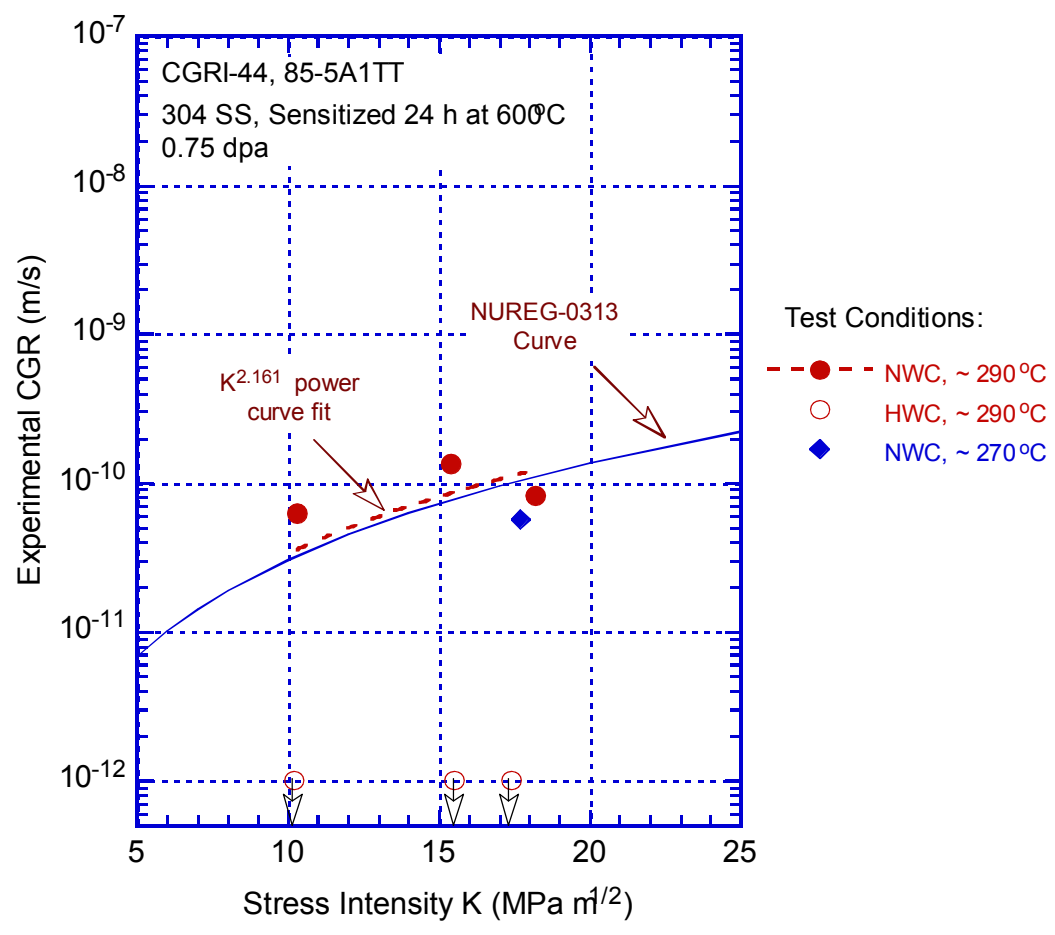

Figure 32. Crack growth rate versus stress intensity under constant-loading conditions for the Type 304 specimen sensitized at $600^{\circ} \mathrm{C}$ for $24 \mathrm{~h}(85-5 \mathrm{~A} 1 \mathrm{TT})$ and irradiated to $0.75 \mathrm{dpa}$.

The temperature dependence of the crack growth rate is shown in Fig. 34 at $\mathrm{K}=17.4 \mathrm{MPa} \mathrm{m}^{1 / 2}$ for the sensitized 304 SS. Since the CGRs measured at low and high temperatures were at different K values for this specimen (as shown in Fig. 32), an expression obtained from a power curve fit $\left(\sim \mathrm{K}^{2.161}\right)$ with all constant-load data points at $290^{\circ} \mathrm{C}$ was used to extrapolate a CGR at the same value of $\mathrm{K}$ that the CGR was obtained at $270^{\circ} \mathrm{C}$. Based on this analysis, the apparent activation energy for this irradiated sensitized Type $304 \mathrm{SS}$ is approximately $42 \mathrm{~kJ} / \mathrm{mol}$ (Fig. 34).

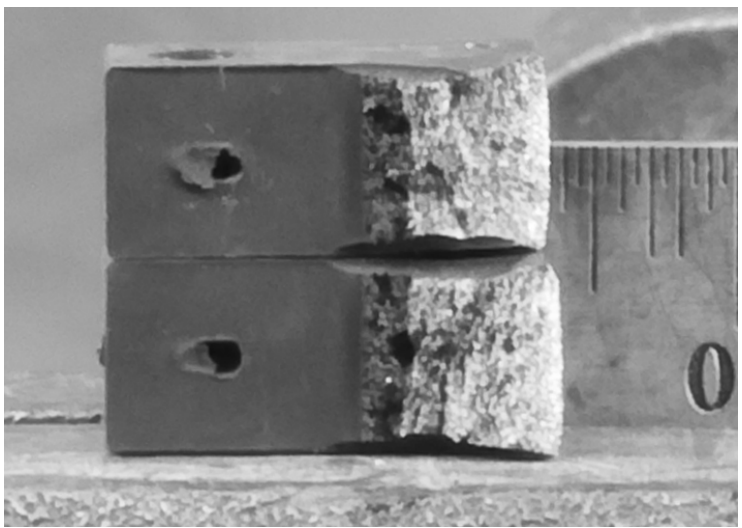

Figure 33. Photograph of the fracture surface of the Type 304 specimen sensitized at $600^{\circ} \mathrm{C}$ for $24 \mathrm{~h}(85-5 \mathrm{~A} 1 \mathrm{TT})$ and irradiated to $0.75 \mathrm{dpa}$. 


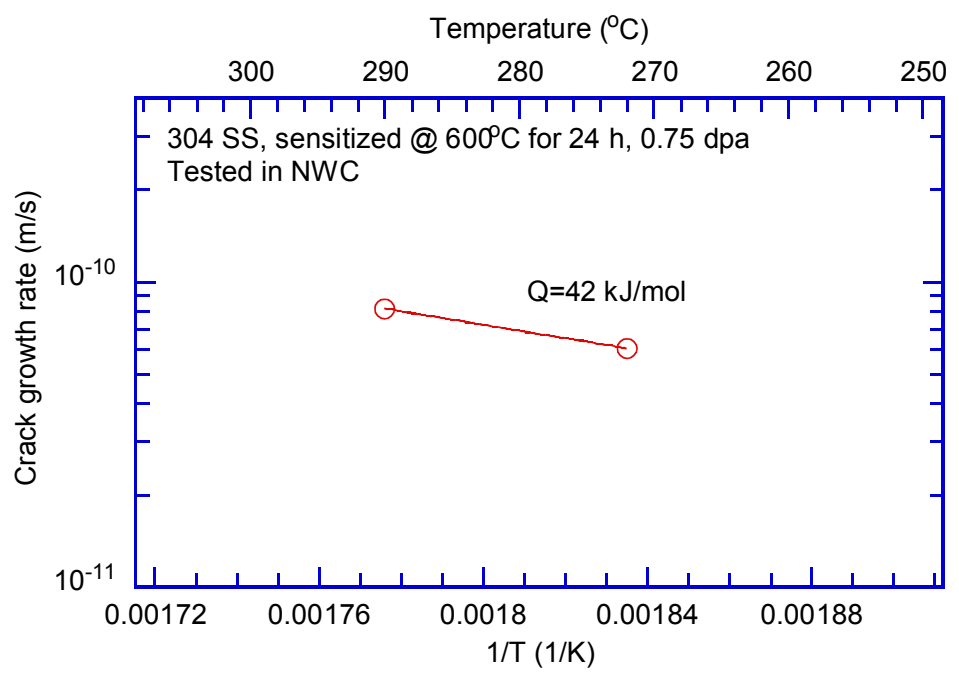

Figure 34. Temperature dependence of CGR for the Type 304 specimen sensitized at $600^{\circ} \mathrm{C}$ for $24 \mathrm{~h}(85-$ 5A1TT, $0.75 \mathrm{dpa})$

\subsection{Type 304 SS with and without GBE Treatment}

\subsubsection{Type 304 SS without GBE Treatment (IT304-01)}

A CGR test on a Type 304 SS specimen (IT304-01) irradiated to $\approx 2$ dpa was performed in simulated BWR water at $\approx 290^{\circ} \mathrm{C}$. This specimen is the baseline material for a companion specimen given the GBE treatment. The test was started in high-purity water with $\approx 350 \mathrm{ppb}$ DO and a flow rate of $\approx 19 \mathrm{~mL} / \mathrm{min}$. The specimen was fatigue precracked at $\mathrm{R}=0.36, \mathrm{~K}_{\max } \approx 18.0 \mathrm{MPa} \mathrm{m} \mathrm{m}^{1 / 2}$, triangular waveform, and $2-\mathrm{Hz}$ frequency. After about $240-\mu \mathrm{m}$ crack advance, $\mathrm{R}$ was increased incrementally, and the triangular waveform was changed to a slow/fast sawtooth waveform. Environmentally enhanced cracking was revealed at $\mathrm{K}_{\max } \approx 19 \mathrm{MPa} \mathrm{m}^{1 / 2}$ with 10 -s rise time in test period 2 .

After the cyclic CGRs were obtained, the specimen was subjected to a constant load in test period 6 , and the SCC CGR was about $1.16 \times 10^{-10} \mathrm{~m} / \mathrm{s}$ at $\mathrm{K}=19.8 \mathrm{MPa} \mathrm{m}^{1 / 2}$. Following a power outage in test period 7, another constant load test was performed, and a significantly lower CGR was measured during this period. An overload caused by the power outage might have contributed to this low growth rate. The loading conditions during the first three or four test periods were repeated in the subsequent test periods to ensure that the test results were comparable to those before the interruption. Finally, another constantload test was carried out in test period 12 at $\mathrm{K}=20.1 \mathrm{MPa} \mathrm{m}^{1 / 2}$. The SCC CGR was determined to be $5.06 \times 10^{-11} \mathrm{~m} / \mathrm{s}$, about half that observed in test period 6 . Table 10 summarizes all test conditions and CGR results, and Fig. 35 shows the crack-length-vs.-time curve of this specimen. The CGRs for this specimen, under both cyclic and constant-load conditions, are somewhat unusual; the cyclic CGRs are a factor of $\approx 5$ lower than those typically observed for austenitic SSs irradiated to similar dose levels (Fig. 36), and the SCC CGRs are either comparable or below the NUREG-0313 curve for nonirradiated sensitized SSs (Fig. 37). 
Table 10. Test results for the base heat of Type 304 specimen (IT304, $\approx 2 \mathrm{dpa})$ in BWR water.

\begin{tabular}{|c|c|c|c|c|c|c|c|c|c|c|c|c|c|c|}
\hline \multirow{2}{*}{$\begin{array}{c}\text { Test } \\
\text { Period }\end{array}$} & \multirow{2}{*}{$\begin{array}{c}\text { Test } \\
\text { Time, } \\
\mathrm{h}\end{array}$} & \multirow{2}{*}{$\begin{array}{c}\text { Test } \\
\text { Temp., } \\
{ }^{\circ} \mathrm{C}\end{array}$} & \multicolumn{2}{|c|}{$\begin{array}{c}\text { ECP }{ }^{\mathrm{a}} \\
\mathrm{mV}(\mathrm{SHE})\end{array}$} & \multirow{2}{*}{$\begin{array}{c}\mathrm{O}_{2} \\
\text { Conc., }{ }^{\mathrm{a}} \\
\mathrm{ppb}\end{array}$} & \multirow{2}{*}{$\begin{array}{c}\text { R } \\
\text { Load } \\
\text { Ratio }\end{array}$} & \multirow{2}{*}{$\begin{array}{c}\text { Rise } \\
\text { Time, } \\
\text { s }\end{array}$} & \multirow{2}{*}{$\begin{array}{c}\text { Return } \\
\text { Time, } \\
\text { s }\end{array}$} & \multirow{2}{*}{$\begin{array}{c}\text { Hold } \\
\text { Time }^{b} \\
\text { s }\end{array}$} & \multirow{2}{*}{$\begin{array}{c}\mathrm{K}_{\max } \\
\mathrm{MPa} \mathrm{m}^{1 / 2}\end{array}$} & \multirow{2}{*}{$\begin{array}{c}\Delta \mathrm{K}, \\
\mathrm{MPa} \mathrm{m}^{1 / 2}\end{array}$} & \multirow{2}{*}{$\begin{array}{c}\text { CGR in } \\
\text { Env., } \\
\text { m/s }\end{array}$} & \multirow{2}{*}{$\begin{array}{c}\text { CGR in } \\
\text { Air, } \\
\mathrm{m} / \mathrm{s}\end{array}$} & \multirow{2}{*}{$\begin{array}{c}\text { Crack } \\
\text { Length } \\
\mathrm{mm}\end{array}$} \\
\hline & & & $\mathrm{Pt}$ & Steel & & & & & & & & & & \\
\hline & & & & & & & & & & & & & & 6.002 \\
\hline Pre & 23 & 290 & - & - & 350 & 0.36 & 0.22 & 0.22 & $0.03 / 0.03$ & 17.8 & 11.3 & $5.95 \mathrm{E}-08$ & 7.81E-08 & 6.242 \\
\hline $1 \mathrm{a}$ & 69 & 290 & - & - & 350 & 0.47 & 25.7 & 3.4 & $4.3 / 0.6$ & 17.7 & 9.4 & $6.44 \mathrm{E}-12$ & $4.02 \mathrm{E}-10$ & 6.259 \\
\hline $1 b$ & 75 & 290 & 248 & 232 & 350 & 0.49 & 8.5 & 1.7 & $1.5 / 0.3$ & 17.7 & 9.1 & $6.47 \mathrm{E}-11$ & $1.10 \mathrm{E}-09$ & 6.263 \\
\hline $1 \mathrm{c}$ & 78 & 290 & 248 & 234 & 350 & 0.46 & 4.3 & 0.9 & $0.7 / 0.1$ & 18.9 & 10.2 & $2.31 \mathrm{E}-09$ & $3.13 \mathrm{E}-09$ & 6.281 \\
\hline 2 & 103 & 290 & 251 & 238 & 350 & 0.46 & 26 & 3.5 & $4.0 / 0.5$ & 19.5 & 10.4 & $1.01 \mathrm{E}-09$ & $5.56 \mathrm{E}-10$ & 6.346 \\
\hline 3 & 148 & 290 & 255 & - & 350 & 0.45 & 261 & 10.4 & $39 / 1.6$ & 19.9 & 11.0 & 4.79E-10 & $6.52 \mathrm{E}-11$ & 6.399 \\
\hline 4 & 212 & 289 & 212 & 202 & 350 & 0.68 & 237 & 9.5 & $63 / 2.5$ & - & - & $3.37 \mathrm{E}-10$ & - & 6.463 \\
\hline 5 & 308 & 288 & 215 & 210 & 350 & 0.67 & 790 & 9.5 & $210 / 2.5$ & 19.7 & 6.4 & $2.22 \mathrm{E}-10$ & $4.46 \mathrm{E}-12$ & 6.523 \\
\hline 6 & 369 & 288 & 224 & 220 & 350 & 1.0 & - & - & - & 19.8 & 0.2 & $1.16 \mathrm{E}-10$ & - & 6.573 \\
\hline 7 & 371 & 288 & Power & utage & & - & - & - & - & - & - & - & - & 6.583 \\
\hline 8 & 489 & 288 & 204 & 208 & 350 & 1.0 & - & - & - & 19.5 & 0.2 & $2.92 \mathrm{E}-11$ & - & 6.598 \\
\hline 9 & 513 & 288 & 202 & 204 & 350 & 0.50 & 254 & 10.0 & $46 / 2.0$ & 19.5 & 9.7 & $4.29 \mathrm{E}-10$ & $4.66 \mathrm{E}-11$ & 6.643 \\
\hline 10 & 537 & 289 & 200 & 203 & 350 & 0.70 & 231 & 9.2 & $69 / 2.8$ & 19.6 & 5.9 & 7.64E-11 & $1.20 \mathrm{E}-11$ & 6.653 \\
\hline 11 & 544 & 289 & 200 & 204 & 350 & 0.56 & 250 & 10.0 & $50 / 2.0$ & 20.0 & 8.8 & $4.61 \mathrm{E}-10$ & $3.62 \mathrm{E}-11$ & 6.663 \\
\hline 12 & 633 & 289 & 200 & 204 & 350 & 1.0 & - & - & - & 20.1 & 0.2 & $5.06 \mathrm{E}-11$ & - & 6.682 \\
\hline
\end{tabular}

Represents values in the effluent In the feedwater, conductivity was $\approx 0.08 \mu \mathrm{S} / \mathrm{cm}$, and DO was $\approx 800$ to $1000 \mathrm{ppb}$

${ }^{\mathrm{b}}$ Hold periods at minimum load during the loading cycle and at maximum load during the unloading cycle.

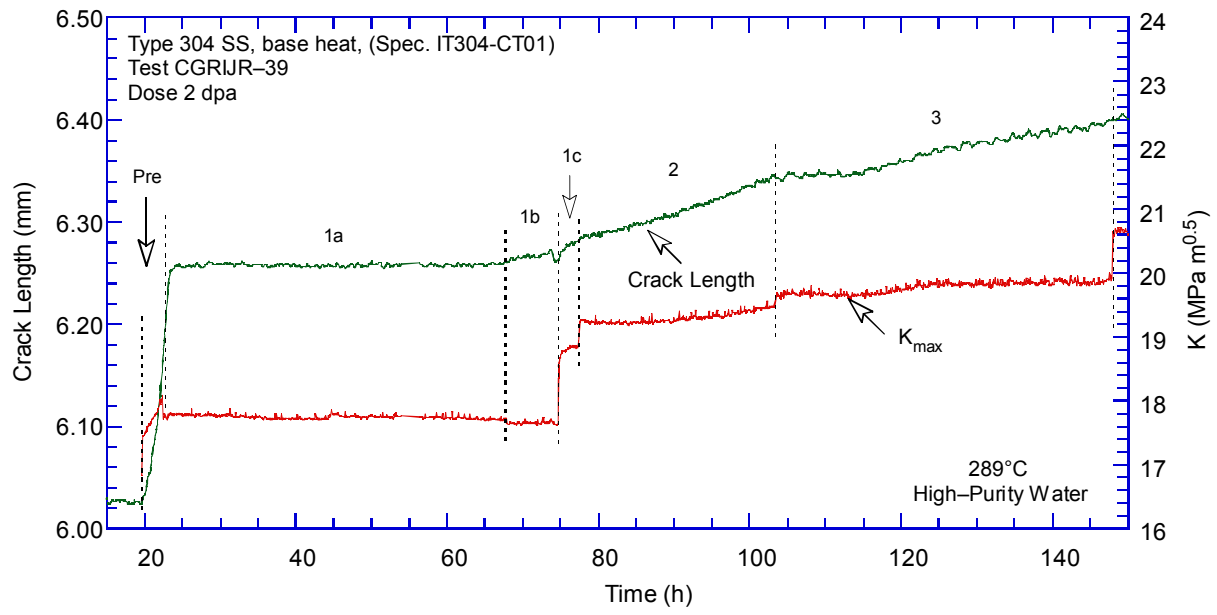

(a)

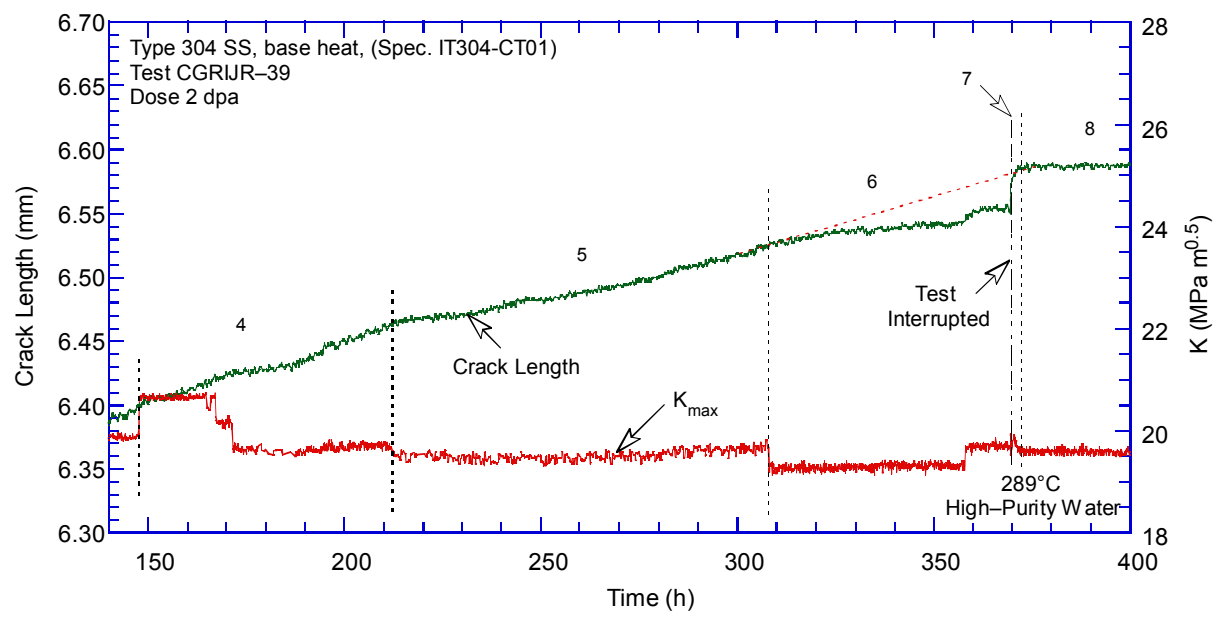

(b)

Figure 35. Crack-length-vs.-time plot for the base heat of Type 304 SS specimen (IT304-01, 2 dpa) in BWR water at $289^{\circ} \mathrm{C}$. 


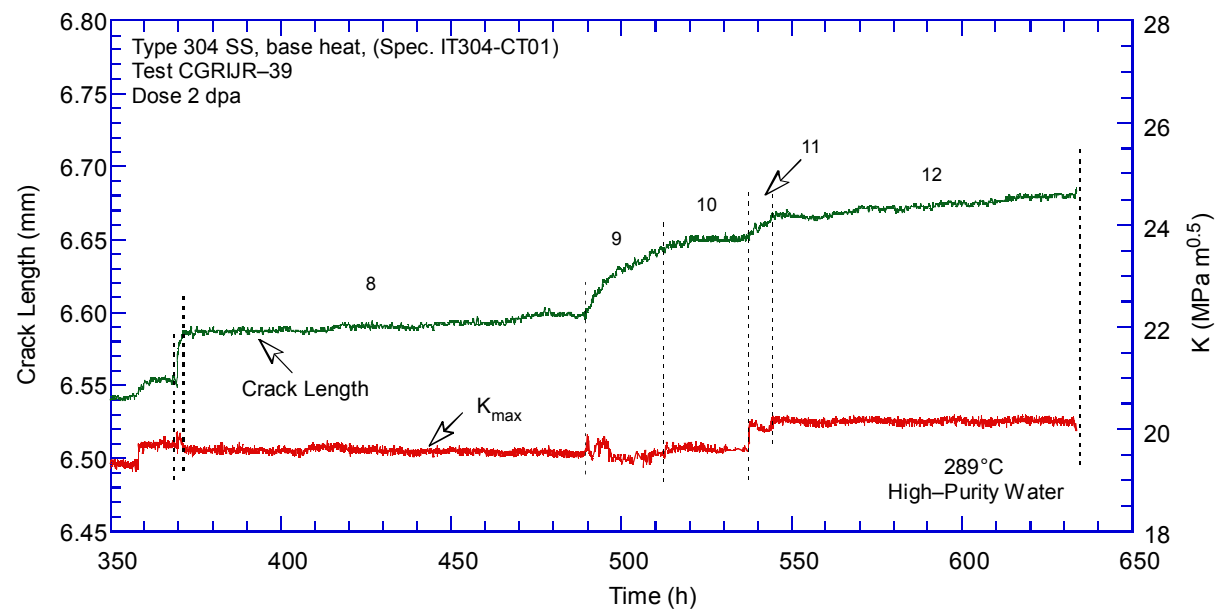

(c)

Figure 35. (Contd.)

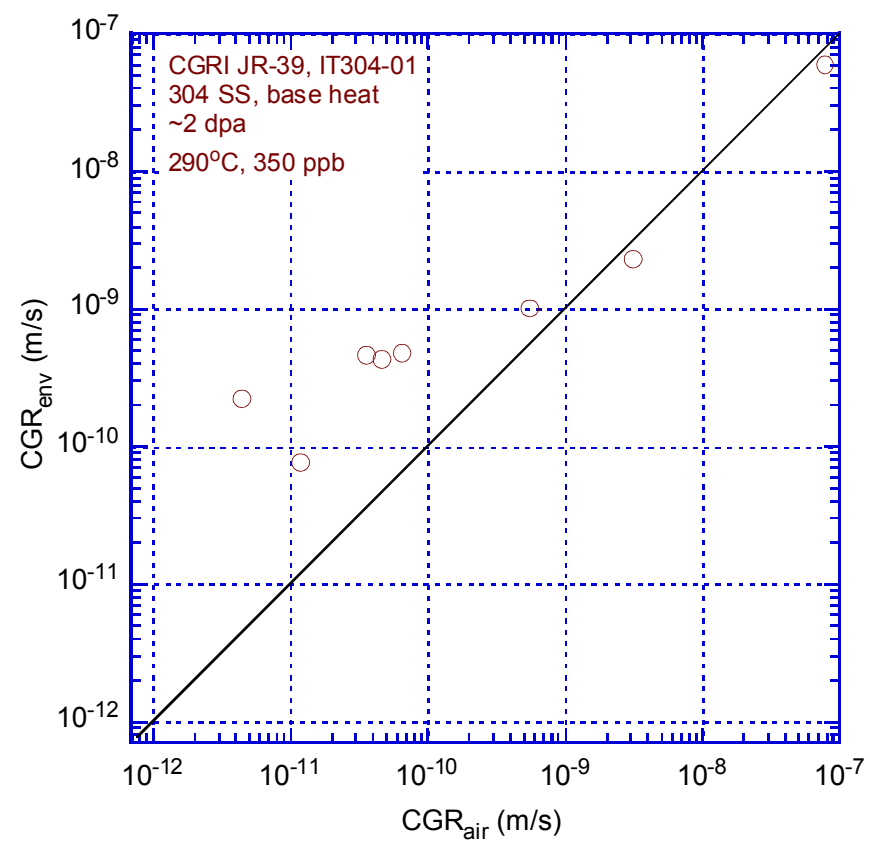

Figure 36. Cyclic CGR for the base heat of Type 304 SS specimen (IT304-01) irradiated to 2 dpa. 


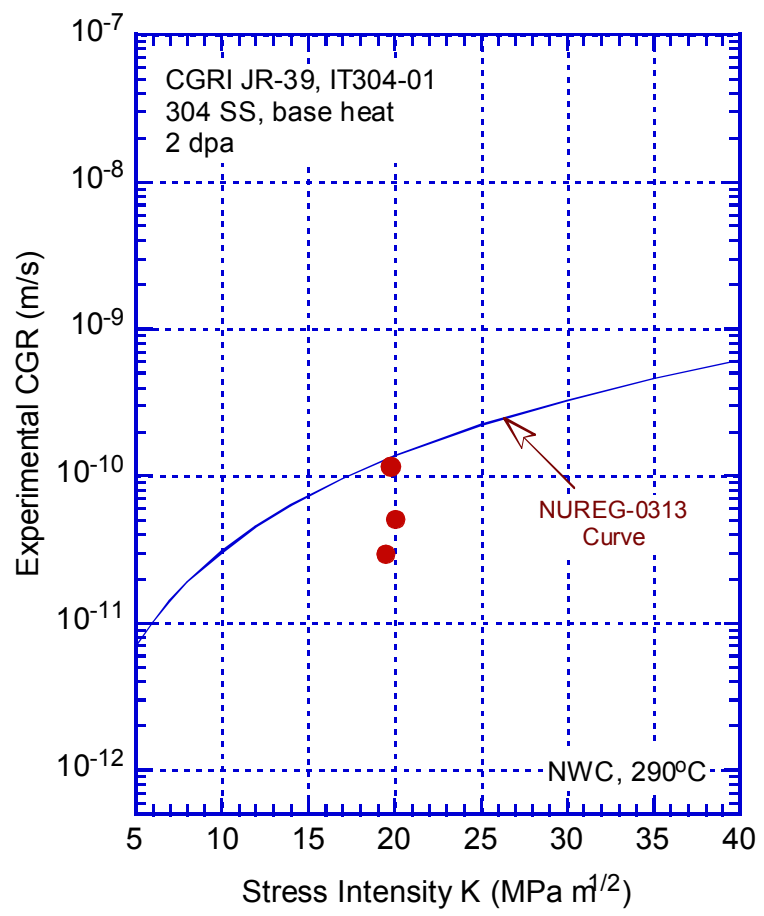

Figure 37. Crack growth rate versus stress intensity under constant-loading conditions for the base heat of Type 304 SS specimen (IT304-01) irradiated to 2 dpa.

After the CGR test, a J-R curve test was performed on the specimen at $289^{\circ} \mathrm{C}$ in high-DO water $(\approx 350 \mathrm{ppb}$ DO). The test was conducted at a constant extension rate of $0.43 \mu \mathrm{m} / \mathrm{s}$. The test was interrupted periodically to measure crack length by DCPD measurements. The measured load vs. loadline displacement and the J-R curves are shown in Figs. 38 and 39, respectively. The $\mathrm{J}_{\mathrm{IC}}$ determined for this non-GBE Type $304 \mathrm{SS}$ is $83 \mathrm{~kJ} / \mathrm{m}^{2}$.

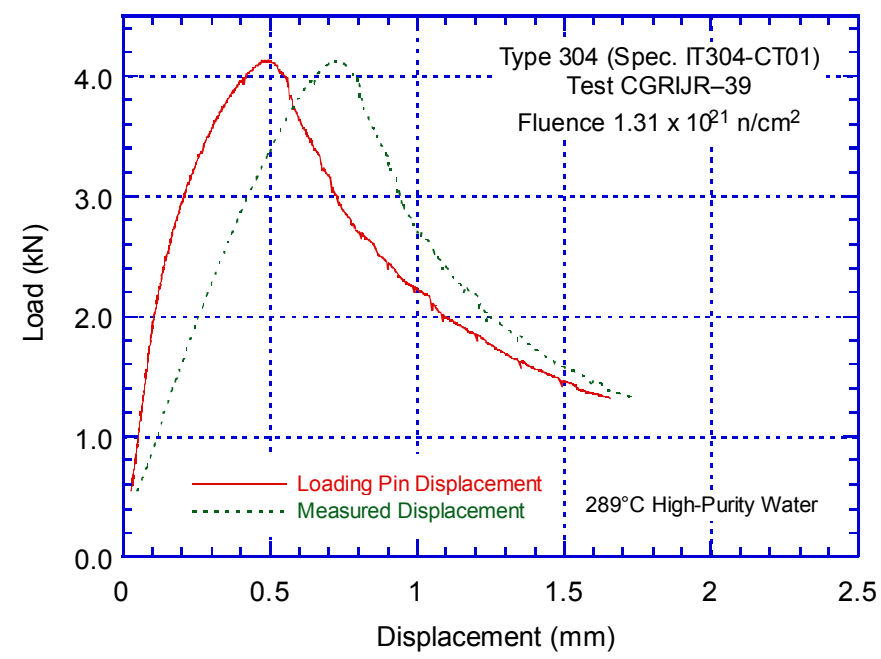

Figure 38. Load vs. load-line displacement curve for the base heat of Type 304 SS specimen (IT304-01) tested in NWC at $289^{\circ} \mathrm{C}$

After the J-R test, the final crack size was marked by fatigue cycling at room temperature. The specimen was then fractured, and the final crack length of both halves of the fractured specimen was measured from the photograph of the fracture surface (Fig. 40). The actual crack extension was about $10 \%$ greater than the value determined from the DCPD measurements. Crack extensions, estimated from the DCPD method, were adjusted accordingly. 

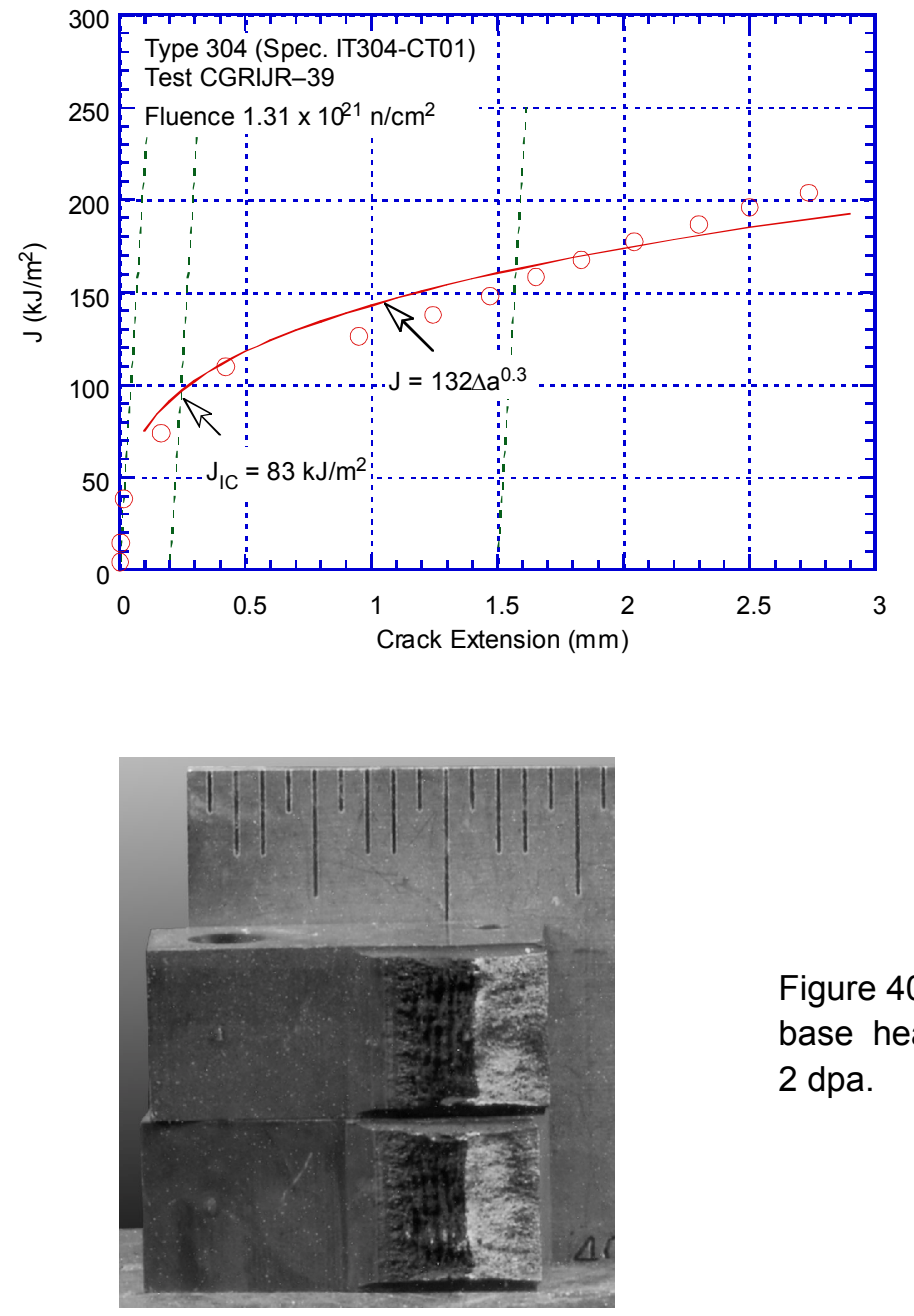

Figure 39. Fracture toughness J-R curves for the base heat of Type 304 SS specimen (IT304-01) tested in NWC at $289^{\circ} \mathrm{C}$.
Figure 40. Photograph of the fracture surface of the base heat of Type 304 SS (IT304-01) irradiated to 2 dpa.

\subsubsection{Type 304 SS with GBE Treatment (GB304-01)}

A CGR test on the GBE-treated Type 304 SS specimen, GB304-01, was carried out in BWR water at $289^{\circ} \mathrm{C}$. The specimen was irradiated to $\approx 2 \mathrm{dpa}$ at $290^{\circ} \mathrm{C}$ in the Halden reactor. The test was started in high-purity water with $\approx 400 \mathrm{ppb} \mathrm{DO}$ and a flow rate of $\approx 19 \mathrm{~mL} / \mathrm{min}$. Fatigue precracking was performed with a triangular waveform at $\mathrm{R}=0.37, \mathrm{Kmax}=18.8 \mathrm{MPa} \mathrm{m}^{1 / 2}$, and $2-\mathrm{Hz}$ frequency. After $\approx 100-\mu \mathrm{m}$ crack advance, the load ratio was increased to $\approx 0.56$, and the waveform was changed to a slow/fast sawtooth with a rise time of $60 \mathrm{~s}$ and a return time of $12 \mathrm{~s}$. After cyclic CGRs were obtained, the specimen was tested under constant load at $17.8,13.2$, and $11.0 \mathrm{MPa} \mathrm{m}^{1 / 2}$. At $96 \mathrm{~h}$, the DO level was decreased from $\approx 400 \mathrm{ppb}$ to $<30 \mathrm{ppb}$ by bubbling the feedwater with a gas mixture of $\mathrm{N}_{2}$ and $4 \% \mathrm{H}_{2}$. Accordingly, the ECP values for both Pt and SS electrodes were reduced significantly, and the constantload CGRs decreased by a factor of 10 . After $\approx 50 \mathrm{~h}$, crack growth became negligible at $\approx 11 \mathrm{MPa} \mathrm{m}{ }^{1 / 2}$. To ensure that the DCPD measurements were not influenced by any unbroken ligaments, the specimen was subjected to cyclic loading at $\mathrm{R}=0.54$, including a sawtooth waveform with $\approx 300$-s rise time for a relatively short time in test period 8 . The cyclic CGR in this test period was determined to be $\approx 3 \times 10^{-9}$ $\mathrm{m} / \mathrm{s}$. Finally, the specimen was subjected to a constant load, and the CGR was measured at $\mathrm{K}=13.9 \mathrm{MPa}$ $\mathrm{m}^{1 / 2}$ in HWC. The CGR test was terminated after $200 \mathrm{~h}$. Table 11 presents all the test conditions and CGR results on this GBE-treated Type 304 specimen, and Fig. 41 shows the crack-length-vs.-time plot. 
Cyclic CGR data are shown in Fig. 42, and constant-load CGRs are given in Fig. 43. Environmental enhancement is evident in this material, and the constant-load CGRs are significantly higher than the NUREG-0313 curve for nonirradiated sensitized SSs.

Table 11. Test results for the GBE-treated Type 304 specimen (GB304-01, $\approx 2 \mathrm{dpa}$ ) in BWR water.

\begin{tabular}{|c|c|c|c|c|c|c|c|c|c|c|c|c|c|c|}
\hline \multirow{2}{*}{$\begin{array}{l}\text { Test } \\
\text { Period }\end{array}$} & \multirow{2}{*}{$\begin{array}{c}\text { Test } \\
\text { Time, } \\
\mathrm{h}\end{array}$} & \multirow{2}{*}{$\begin{array}{l}\text { Test } \\
\text { Temp., } \\
{ }^{\circ} \mathrm{C}\end{array}$} & \multicolumn{2}{|c|}{$\begin{array}{c}\text { ECP, }^{\mathrm{a}} \\
\mathrm{mV} \text { (SHE) }\end{array}$} & \multirow{2}{*}{$\begin{array}{c}\mathrm{O}_{2} \\
\text { Conc., } \\
\text { ppb }\end{array}$} & \multirow{2}{*}{$\begin{array}{c}\text { R } \\
\text { Load } \\
\text { Ratio }\end{array}$} & \multirow{2}{*}{$\begin{array}{c}\text { Rise } \\
\text { Time, } \\
\text { s }\end{array}$} & \multirow{2}{*}{$\begin{array}{c}\text { Return } \\
\text { Time, } \\
\mathrm{s}\end{array}$} & \multirow{2}{*}{$\begin{array}{c}\text { Hold } \\
\text { Time, } \\
\text { s }\end{array}$} & \multirow{2}{*}{$\begin{array}{c}\mathrm{K}_{\max } \\
\mathrm{MPa} \mathrm{m}^{1 / 2}\end{array}$} & \multirow{2}{*}{$\begin{array}{c}\Delta \mathrm{K}, \\
\mathrm{MPa} \mathrm{m}^{1 / 2}\end{array}$} & \multirow{2}{*}{$\begin{array}{c}\text { CGR in } \\
\text { Env., } \\
\mathrm{m} / \mathrm{s}\end{array}$} & \multirow{2}{*}{$\begin{array}{c}\text { CGR in } \\
\text { Air, } \\
\mathrm{m} / \mathrm{s}\end{array}$} & \multirow{2}{*}{$\begin{array}{c}\text { Crack } \\
\text { Length, } \\
\mathrm{mm}\end{array}$} \\
\hline & & & $\mathrm{Pt}$ & Steel & & & & & & & & & & \\
\hline & & & & & & & & & & & & & & 6.043 \\
\hline Pre & 25 & 288 & - & - & 400 & 0.37 & 0.22 & 0.22 & $0.03 / 0.03$ & 18.8 & 11.9 & $9.68 \mathrm{E}-08$ & $9.11 \mathrm{E}-08$ & 6.331 \\
\hline 1 & 29 & 289 & - & - & 400 & 0.53 & 4.9 & 0.8 & $1.1 / 0.2$ & 18.3 & 8.6 & $9.53 \mathrm{E}-09$ & 1.69E-09 & 6.413 \\
\hline 2 & 45 & 289 & 251 & 238 & 400 & 0.53 & 49.2 & 9.8 & $10.8 / 2.2$ & 18.6 & 8.8 & $2.96 \mathrm{E}-09$ & $1.76 \mathrm{E}-10$ & 6.532 \\
\hline 3 & 56 & 288 & 255 & 238 & 400 & 0.58 & 47.6 & 9.5 & $12.4 / 2.5$ & 17.1 & 7.2 & $2.85 \mathrm{E}-09$ & $1.01 \mathrm{E}-10$ & 6.609 \\
\hline 4 & 69 & 288 & 234 & 228 & 400 & 1.0 & - & - & - & 17.8 & 0.3 & 2.72E-09 & - & 6.732 \\
\hline 5 & 77 & 288 & 215 & 210 & 400 & 1.0 & - & - & - & 13.2 & 0.3 & $1.40 \mathrm{E}-09$ & - & 6.786 \\
\hline 6 & 96 & 289 & 196 & 154 & 400 & 1.0 & - & - & - & 10.9 & 0.2 & $1.16 \mathrm{E}-09$ & - & 6.863 \\
\hline 7 & 166 & 288 & -524 & -265 & $<30$ & 1.0 & - & - & - & 11.0 & 0.2 & negligible & - & 6.908 \\
\hline 8 & 170 & 289 & -527 & -273 & $<30$ & 0.54 & 217 & 8.7 & $83 / 3.3$ & 12.2 & 5.7 & $3.02 \mathrm{E}-09$ & $9.45 \mathrm{E}-12$ & 6.948 \\
\hline 9 & 272 & 288 & -465 & -374 & $<30$ & 1.0 & - & - & - & 13.9 & 0.3 & $2.04 \mathrm{E}-10$ & - & 7.016 \\
\hline
\end{tabular}

$\mathrm{b}$ Hold periods at minimum load during the loading cycle and at maximum load during the unloading cycle.

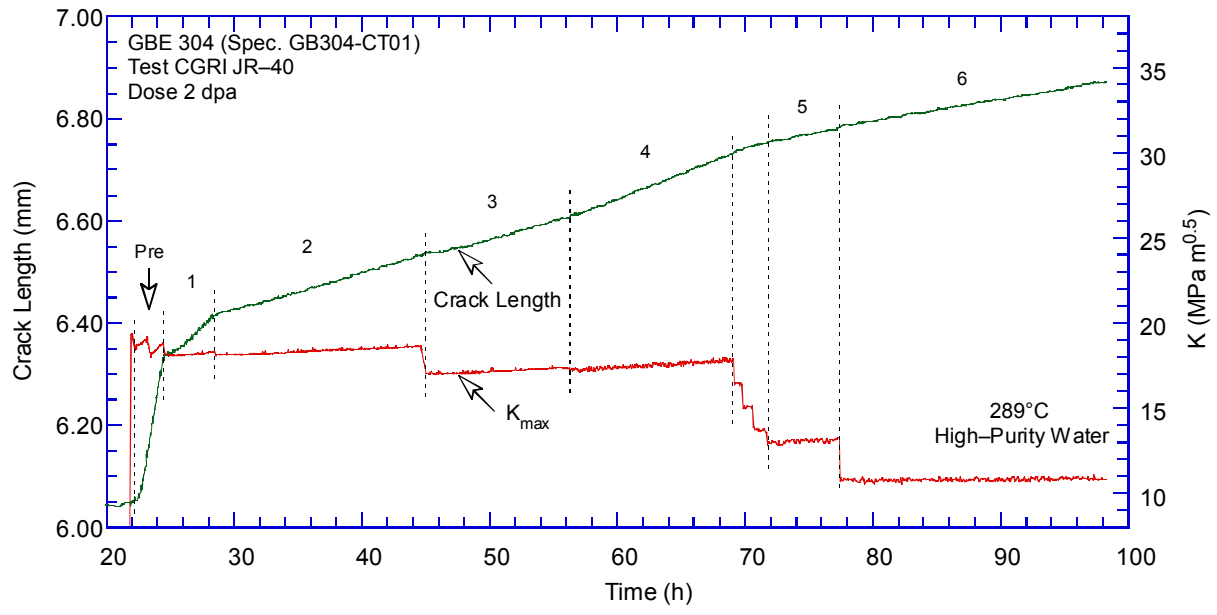

(a)

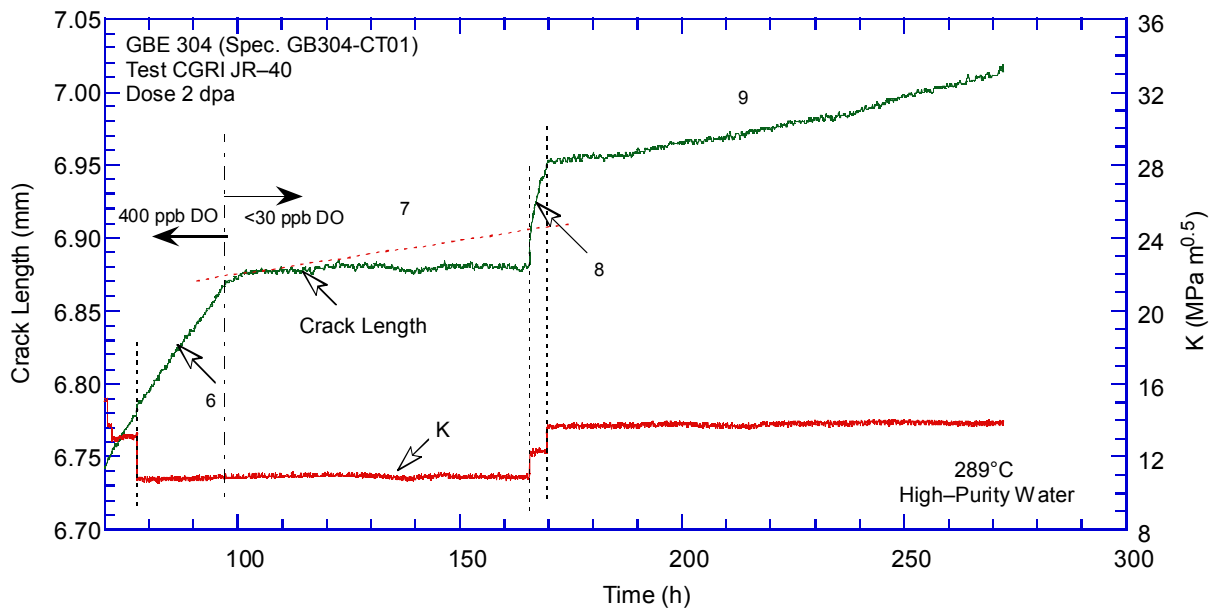

(b)

Figure 41. Crack-length-vs.-time plot for the GBE-treated Type 304 SS specimen (GB304-01, $\approx 2 \mathrm{dpa}$ ) in BWR water at $289^{\circ} \mathrm{C}$. 

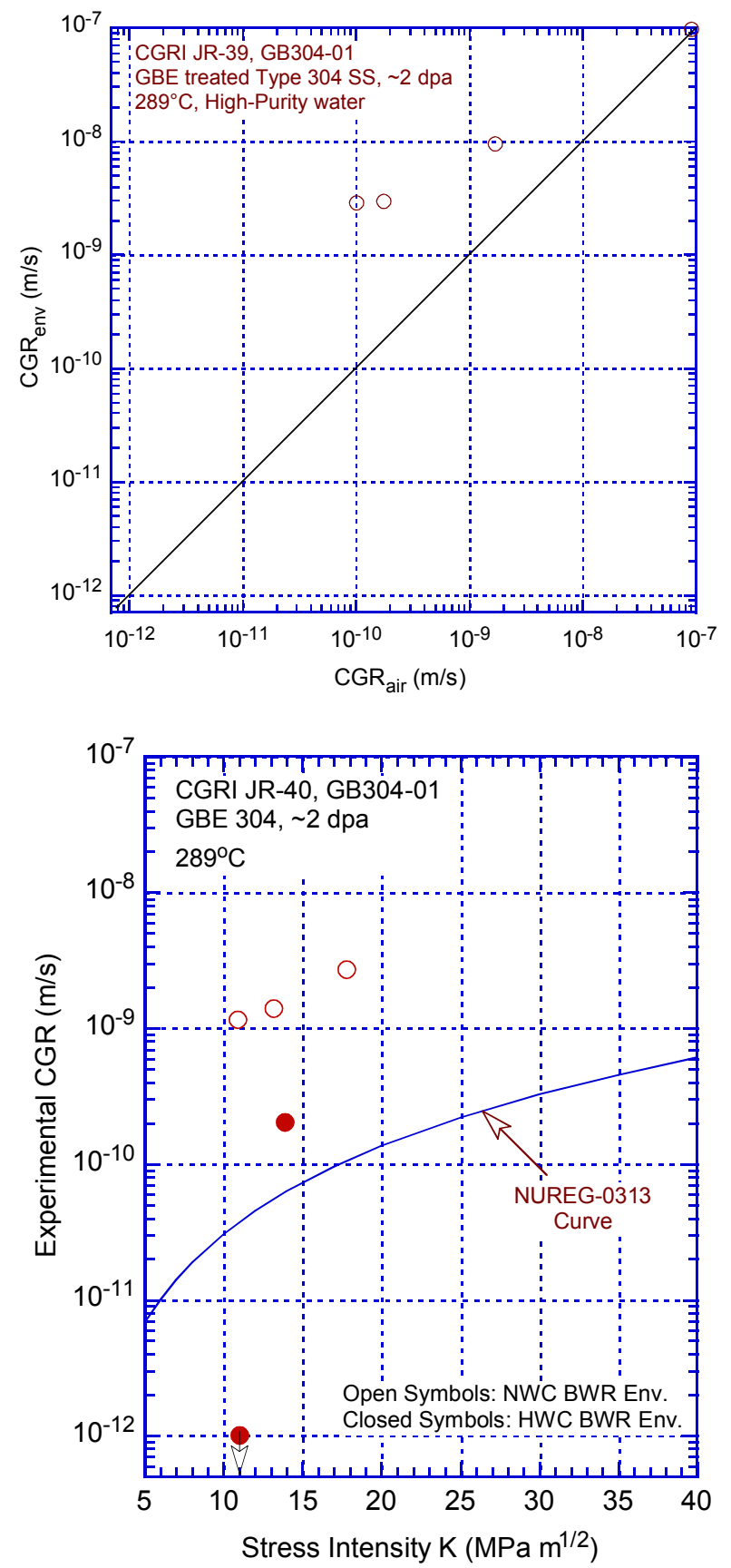

Figure 42. Cyclic crack growth rate for the GBE-treated Type 304 SS specimen (GB30401) irradiated to 2 dpa.

Figure 43. Crack growth rate versus stress intensity under constant-loading conditions for the GBE-treated Type 304 SS specimen (GB304-01) irradiated to 2 dpa.

The DO level in the system was increased to $\approx 400 \mathrm{ppb}$ after the CGR test. A J-R curve test was then performed on the specimen at $289^{\circ} \mathrm{C}$ in the high-purity water. The test was conducted at a constant extension rate of $\approx 0.43 \mu \mathrm{m} / \mathrm{s}$, and the test was interrupted periodically to measure crack length by the DCPD method. The load vs. load-line displacement curve is shown in Fig. 44, and the corresponding J-R curve is given in Fig. 45. The final crack size was marked by fatigue cycling at room temperature. The specimen was then fractured, and the final crack length of both halves of the fractured specimen was measured from the photograph of the fracture surface (Fig. 46). The actual crack extension was $\approx 27 \%$ greater than the value determined from the DCPD measurement. Crack extensions, estimated from the DC potential method, were adjusted accordingly. 

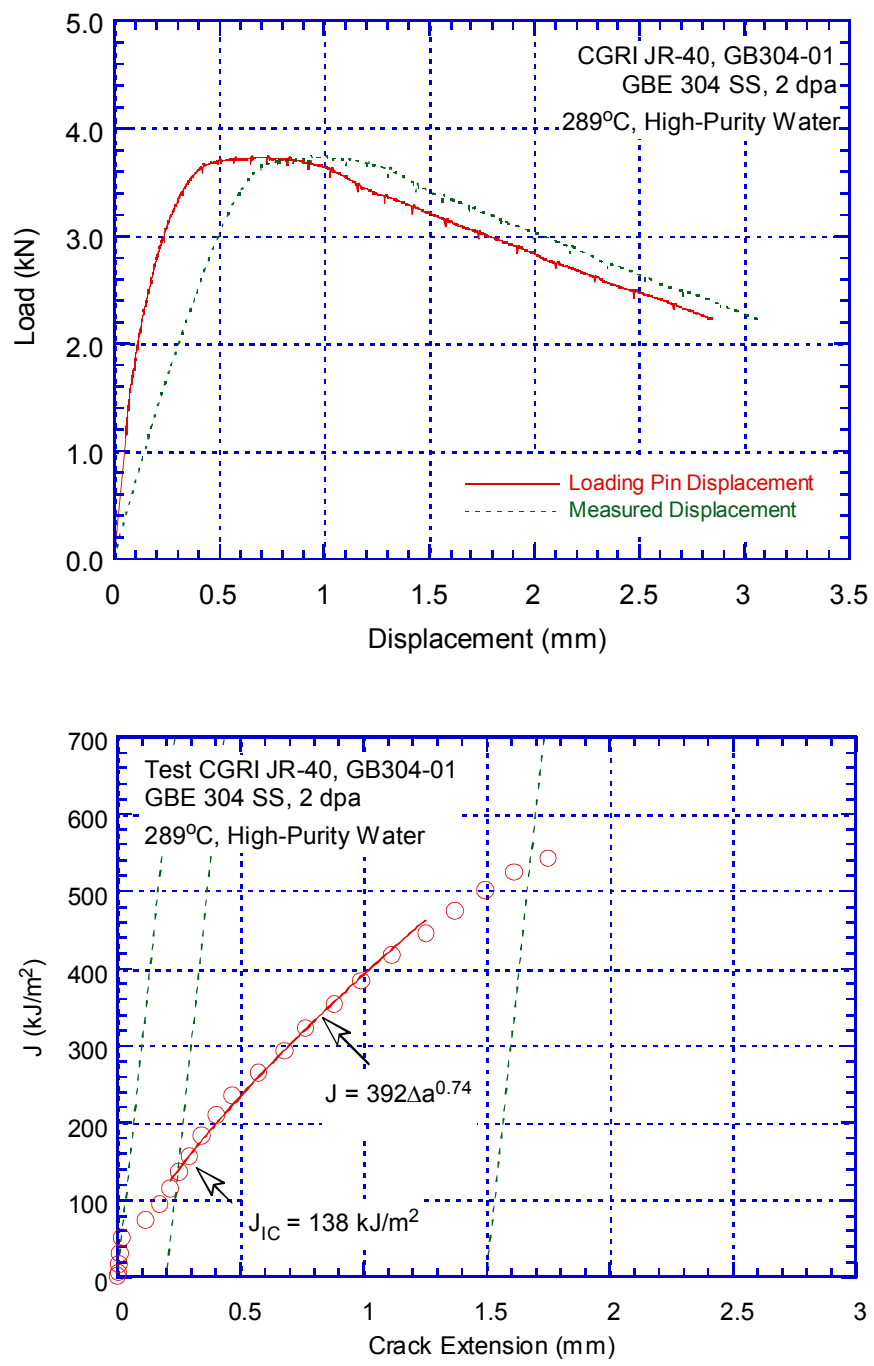

Figure 44. Load vs. load-line displacement curve for the GBE-treated Type 304 SS (GB304-01, 2 dpa) tested in NWC at $289^{\circ} \mathrm{C}$.
Figure 45. Fracture toughness J-R curves for the GBE-treated Type 304 SS (GB304$01, \sim 2 \mathrm{dpa}$ ) tested in NWC at $289^{\circ} \mathrm{C}$.

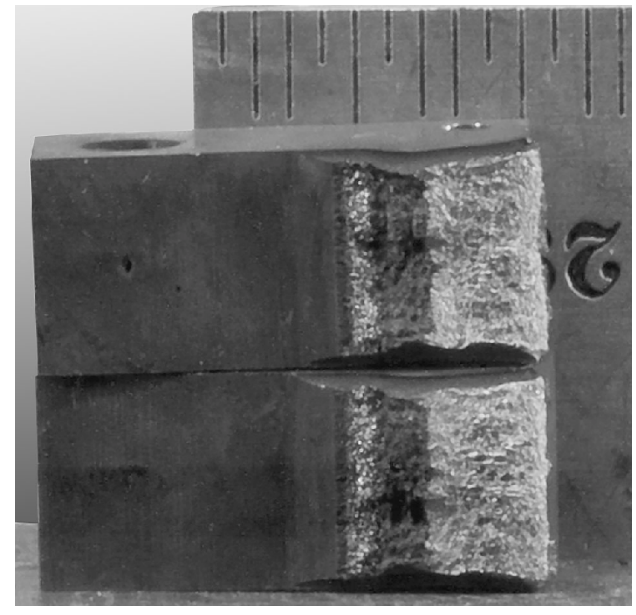

Figure 46. Photograph of the fracture surface of the GBE-treated Type 304 SS (GB304-01) irradiated to 2 dpa. 


\subsection{Type 316 SS with and without GBE Treatment}

\subsubsection{Type 316 without GBE Treatment (IT316-01)}

A CGR test was performed in simulated BWR water at $289^{\circ} \mathrm{C}$ on a Type 316 SS specimen (IT316-01) that was irradiated to $\approx 2 \mathrm{dpa}$. The specimen is the baseline material for a companion specimen that has been given the GBE treatment. The test was started in high-purity water with $\approx 700 \mathrm{ppb}$ DO and a flow rate of $\approx 20 \mathrm{~mL} / \mathrm{min}$. Fatigue precracking was conducted with a triangular waveform at $\mathrm{R} \approx 0.35, \mathrm{~K}_{\max } \approx 18 \mathrm{MPa} \mathrm{m}{ }^{1 / 2}$, and frequency of $2 \mathrm{~Hz}$. After about $150-\mu \mathrm{m}$ crack advance, $\mathrm{R}$ was increased to 0.5 , and the waveform was changed to a slow/fast sawtooth with rise times of 1 to $60 \mathrm{~s}$ and return times of 1 to $12 \mathrm{~s}$. The first attempt to introduce environmentally enhanced cracking was unsuccessful, and the cyclic CGRs in the test environment were generally comparable to those in air under the same loading conditions. The $\mathrm{K}_{\max }$ was then increased to $\approx 20 \mathrm{MPa} \mathrm{m}^{1 / 2}$, and the initial loading sequence was repeated. Environmental enhancement was achieved during test period 8. Subsequently, the specimen was subjected to constant load. Table 12 summarizes all the test conditions and CGR results, and Fig. 47 shows the crack-length-vs.-time plot of this specimen.

Cyclic CGR data are shown in Fig. 48, and constant-load CGRs are given in Fig. 49. Little environmental effect can be seen for the cyclic CGRs. The CGRs in test period 2, 3, and 5a are not included in the figure due to insignificant crack advance. Under the constant-load conditions, the measured CGRs are very close to the NUREG-0313 curve, as shown in Fig. 49.

Table 12. Test results for the base heat of Type 316 specimen (IT316-01, $\approx 2 \mathrm{dpa}$ ) in BWR water.

\begin{tabular}{|c|c|c|c|c|c|c|c|c|c|c|c|c|c|c|}
\hline \multirow{2}{*}{$\begin{array}{c}\text { Test } \\
\text { Period }\end{array}$} & \multirow{2}{*}{$\begin{array}{c}\text { Test } \\
\text { Time, } \\
\mathrm{h}\end{array}$} & \multirow{2}{*}{$\begin{array}{c}\text { Test } \\
\text { Temp., } \\
{ }^{\circ} \mathrm{C} \\
\end{array}$} & \multicolumn{2}{|c|}{$\begin{array}{c}\text { ECP, }{ }^{\mathrm{a}} \\
\mathrm{mV}(\mathrm{SHE})\end{array}$} & \multirow{2}{*}{$\begin{array}{c}\mathrm{O}_{2} \\
\text { Conc., } \\
\text { ppb }\end{array}$} & \multirow{2}{*}{$\begin{array}{c}\mathrm{R} \\
\text { Load } \\
\text { Ratio } \\
\end{array}$} & \multirow{2}{*}{$\begin{array}{c}\text { Rise } \\
\text { Time, } \\
\mathrm{s} \\
\end{array}$} & \multirow{2}{*}{$\begin{array}{c}\text { Return } \\
\text { Time, } \\
\text { s } \\
\end{array}$} & \multirow{2}{*}{$\begin{array}{c}\text { Hold } \\
\text { Time, } \\
\text { s } \\
\end{array}$} & \multirow{2}{*}{$\begin{array}{c}\mathrm{K}_{\max }, \\
\mathrm{MPa} \mathrm{m}^{1 / 2}\end{array}$} & \multirow{2}{*}{$\begin{array}{c}\Delta \mathrm{K}, \\
\mathrm{MPa} \mathrm{m}^{1 / 2}\end{array}$} & \multirow{2}{*}{$\begin{array}{c}\text { CGR in } \\
\text { Env., } \\
\mathrm{m} / \mathrm{s}\end{array}$} & \multirow{2}{*}{$\begin{array}{c}\text { CGR in } \\
\text { Air, } \\
\text { m/s }\end{array}$} & \multirow{2}{*}{$\begin{array}{c}\text { Crack } \\
\text { Length, } \\
\mathrm{mm}\end{array}$} \\
\hline & & & $\mathrm{Pt}$ & Steel & & & & & & & & & & \\
\hline Pre & 21 & 288 & 266 & 208 & 600 & 0.34 & 0.22 & 0.22 & $0.03 / 0.03$ & 18.3 & 12.1 & $5.37 \mathrm{E}-08$ & $9.33 \mathrm{E}-08$ & $\begin{array}{l}6.022 \\
6.185\end{array}$ \\
\hline 1 & 26 & 288 & 266 & 208 & 600 & 0.37 & 0.87 & 0.87 & $0.13 / 0.13$ & 17.7 & 11.1 & $2.69 \mathrm{E}-08$ & $1.87 \mathrm{E}-08$ & 6.369 \\
\hline 2 & 66 & 288 & 271 & 209 & 600 & 0.53 & 49.4 & 9.90 & $10.6 / 2.1$ & 16.8 & 8.0 & $3.85 \mathrm{E}-11$ & $1.27 \mathrm{E}-10$ & 6.382 \\
\hline 3 & 70 & 288 & 271 & 208 & 600 & 0.48 & 25.2 & 3.40 & $4.8 / 0.6$ & 17.4 & 9.0 & negligible & $3.59 \mathrm{E}-10$ & 6.383 \\
\hline 4 & 163 & 288 & 274 & 208 & 600 & 0.51 & 25.5 & 3.40 & $4.5 / 0.6$ & 19.9 & 9.7 & $3.54 \mathrm{E}-10$ & $4.68 \mathrm{E}-10$ & 6.439 \\
\hline $5 \mathrm{a}$ & 165 & 288 & 274 & 208 & 600 & 0.37 & 0.88 & 0.88 & $0.12 / 0.12$ & 19.4 & 12.2 & negligible & $2.49 \mathrm{E}-08$ & 6.439 \\
\hline $5 b$ & 167 & 288 & 273 & 208 & 600 & 0.33 & 0.22 & 0.22 & $0.03 / 0.03$ & 21.2 & 14.2 & $9.00 \mathrm{E}-08$ & $1.57 \mathrm{E}-07$ & 6.668 \\
\hline 6 & 187 & 288 & 273 & 208 & 600 & 0.48 & 25.5 & 3.40 & $4.5 / 0.6$ & 20.4 & 10.6 & $2.69 \mathrm{E}-10$ & $6.10 \mathrm{E}-10$ & 6.707 \\
\hline 7 & 210 & 289 & 274 & 208 & 600 & 0.45 & 25.7 & 3.40 & $4.3 / 0.6$ & 20.5 & 11.3 & $2.00 \mathrm{E}-10$ & $7.13 \mathrm{E}-10$ & 6.720 \\
\hline 8 & 234 & 289 & 275 & 208 & 600 & 0.43 & 10.3 & 1.70 & $1.7 / 0.3$ & 20.9 & 11.8 & $3.16 \mathrm{E}-09$ & $2.05 \mathrm{E}-09$ & 6.820 \\
\hline 9 & 332 & 289 & 275 & 209 & 600 & 0.40 & 51.7 & 3.40 & $8.3 / 0.6$ & 20.5 & 12.2 & $2.59 \mathrm{E}-10$ & $4.41 \mathrm{E}-10$ & 6.881 \\
\hline 10 & 356 & 289 & 275 & 209 & 600 & 0.43 & 103 & 3.40 & $17.2 / 0.6$ & 20.9 & 11.9 & $2.41 \mathrm{E}-10$ & $2.09 \mathrm{E}-10$ & 6.903 \\
\hline 11 & 380 & 289 & 274 & 208 & 600 & 0.44 & 257 & 10.3 & $43.3 / 1.7$ & 21.3 & 11.8 & $2.76 \mathrm{E}-10$ & $8.33 \mathrm{E}-11$ & 6.921 \\
\hline 12 & 405 & 289 & 274 & 209 & 600 & 0.50 & 253 & 10.1 & $47.4 / 1.9$ & 21.4 & 10.7 & $2.87 \mathrm{E}-10$ & $6.46 \mathrm{E}-11$ & 6.943 \\
\hline 13 & 478 & 289 & 273 & 209 & 600 & 1.0 & - & - & - & 20.6 & 0.2 & $1.49 \mathrm{E}-10$ & - & 6.990 \\
\hline 14 & 547 & 289 & 273 & 210 & 600 & 1.0 & - & - & - & 16.5 & 0.2 & $6.70 \mathrm{E}-11$ & - & 6.997 \\
\hline
\end{tabular}

${ }^{\mathrm{a}}$ Represents values in the effluent. In the feedwater, conductivity was $\approx 0.1 \mu \mathrm{S} / \mathrm{cm}$, and DO was $\approx 800$ to $1000 \mathrm{ppb}$.

$\mathrm{b}$ Hold periods at minimum load during the loading cycle and at maximum load during the unloading cycle. 


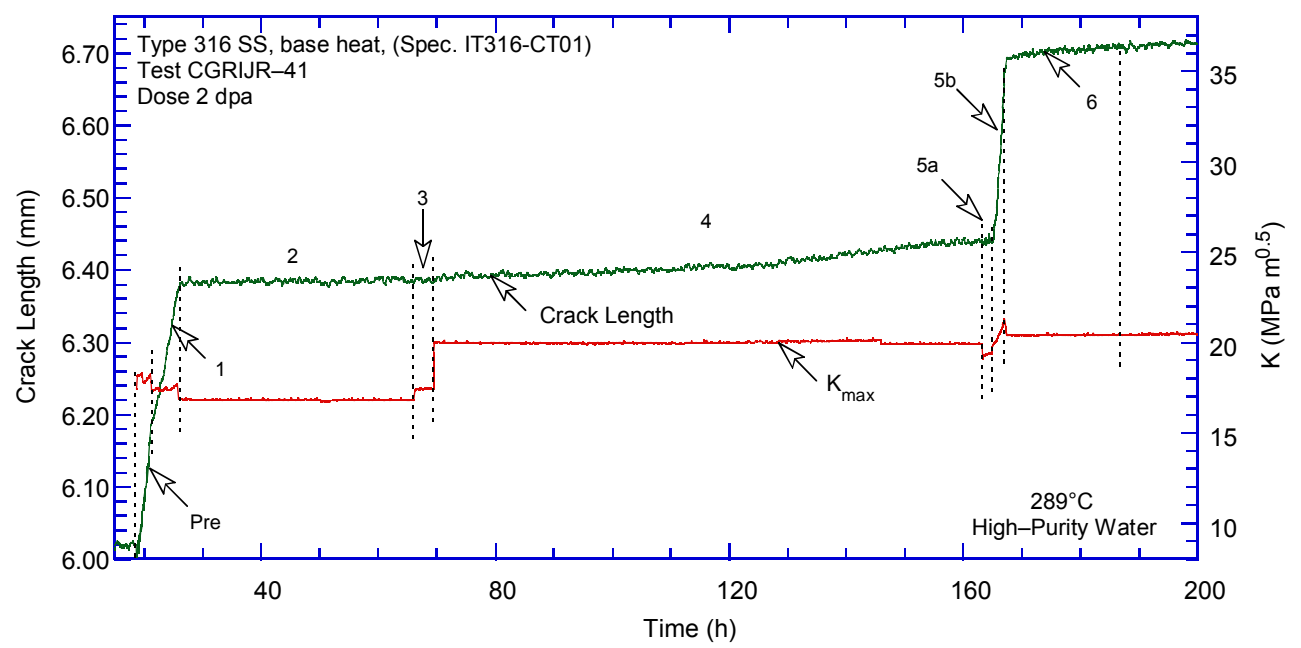

(a)

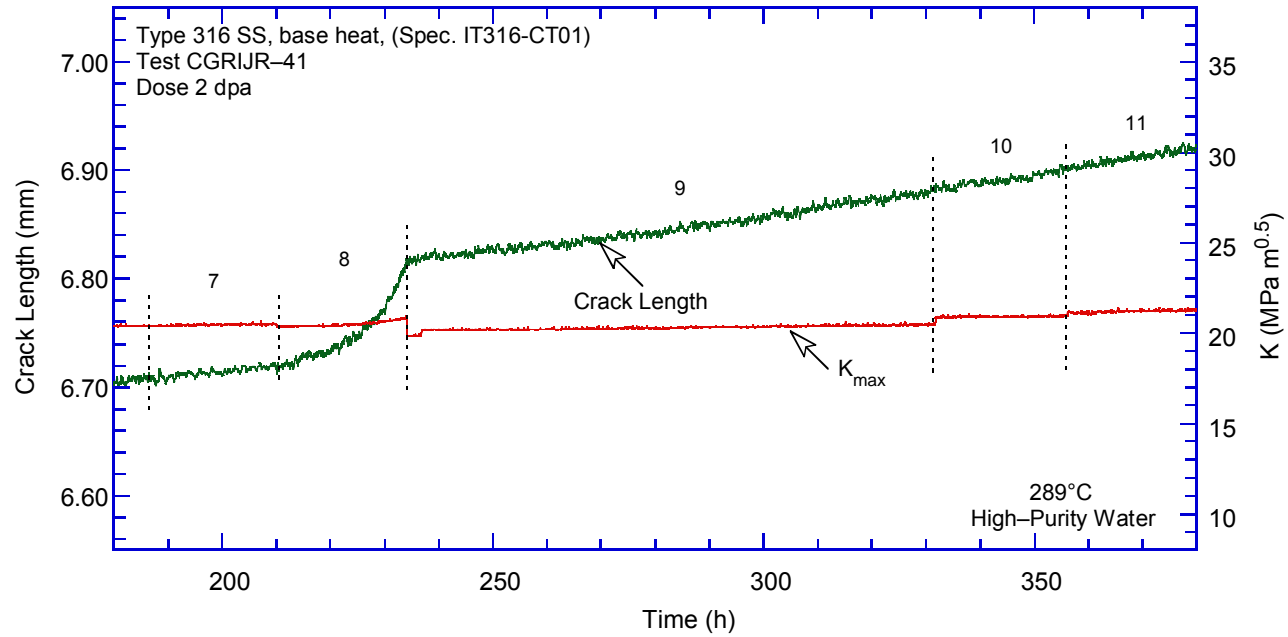

(b)

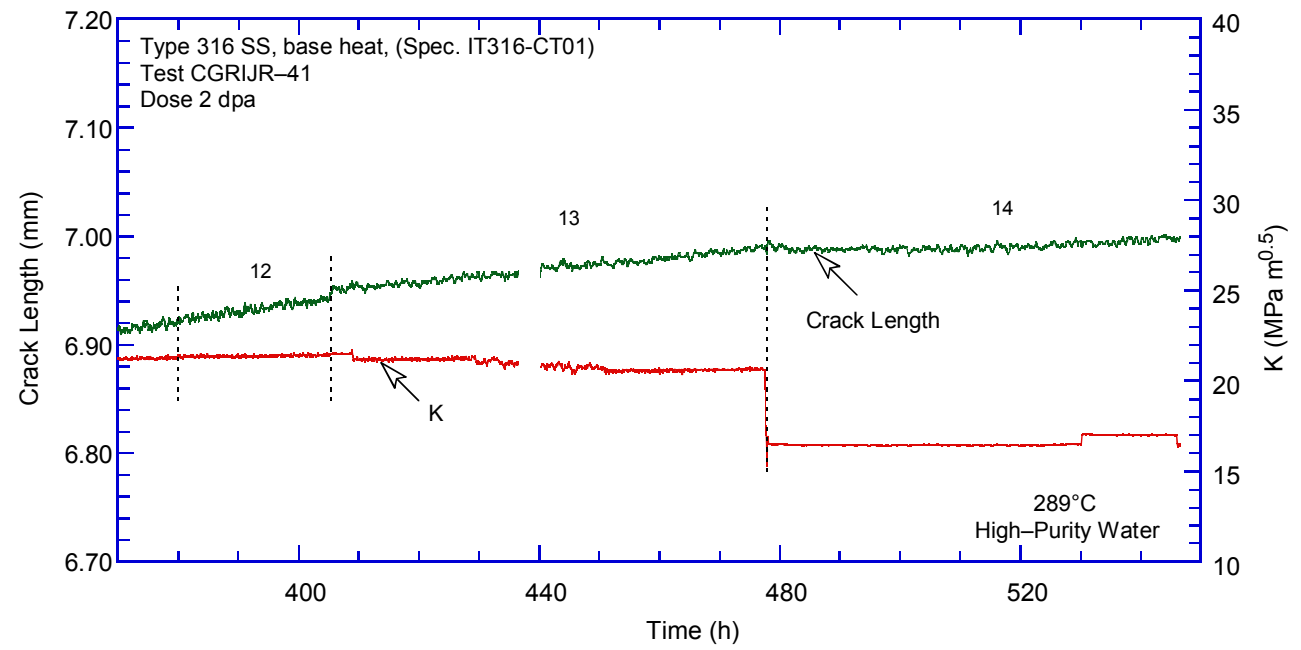

(c)

Figure 47. Crack-length-vs.-time plot for the base heat of Type 316 SS specimen (IT316-01, $\approx 2 \mathrm{dpa}$ ) in BWR water at $289^{\circ} \mathrm{C}$. 

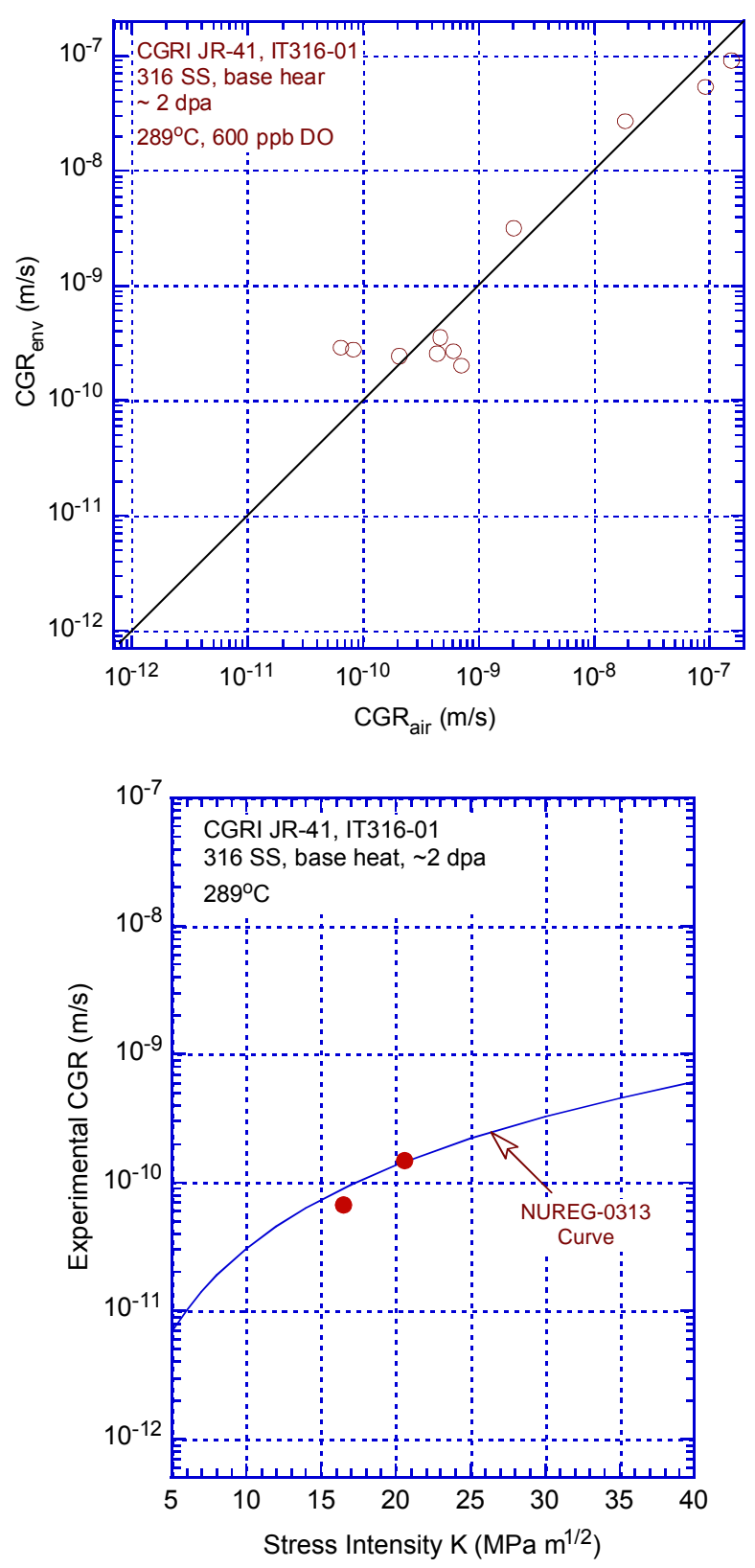

Figure 48. Cyclic CGR for the base heat of Type 316 SS (IT316-01) irradiated to 2 dpa.

Figure 49. Crack growth rate versus stress intensity under constant-loading conditions for the base heat of Type 316 SS (IT316-01) irradiated to 2 dpa.

After the CGR test, a J-R curve test was performed on the specimen at $289^{\circ} \mathrm{C}$ in high-DO water ( $\approx 600 \mathrm{ppb}$ DO). The test was conducted at a constant extension rate of $0.43 \mu \mathrm{m} / \mathrm{s}$. The test was interrupted periodically to measure crack length by DCPD measurements. The load vs. load-line displacement curve is shown in Fig. 50, and the corresponding J-R curve is shown in Fig. 51. The $\mathrm{J}_{1 \mathrm{C}}$ determined for this specimen is $89 \mathrm{~kJ} / \mathrm{m}^{2}$. 

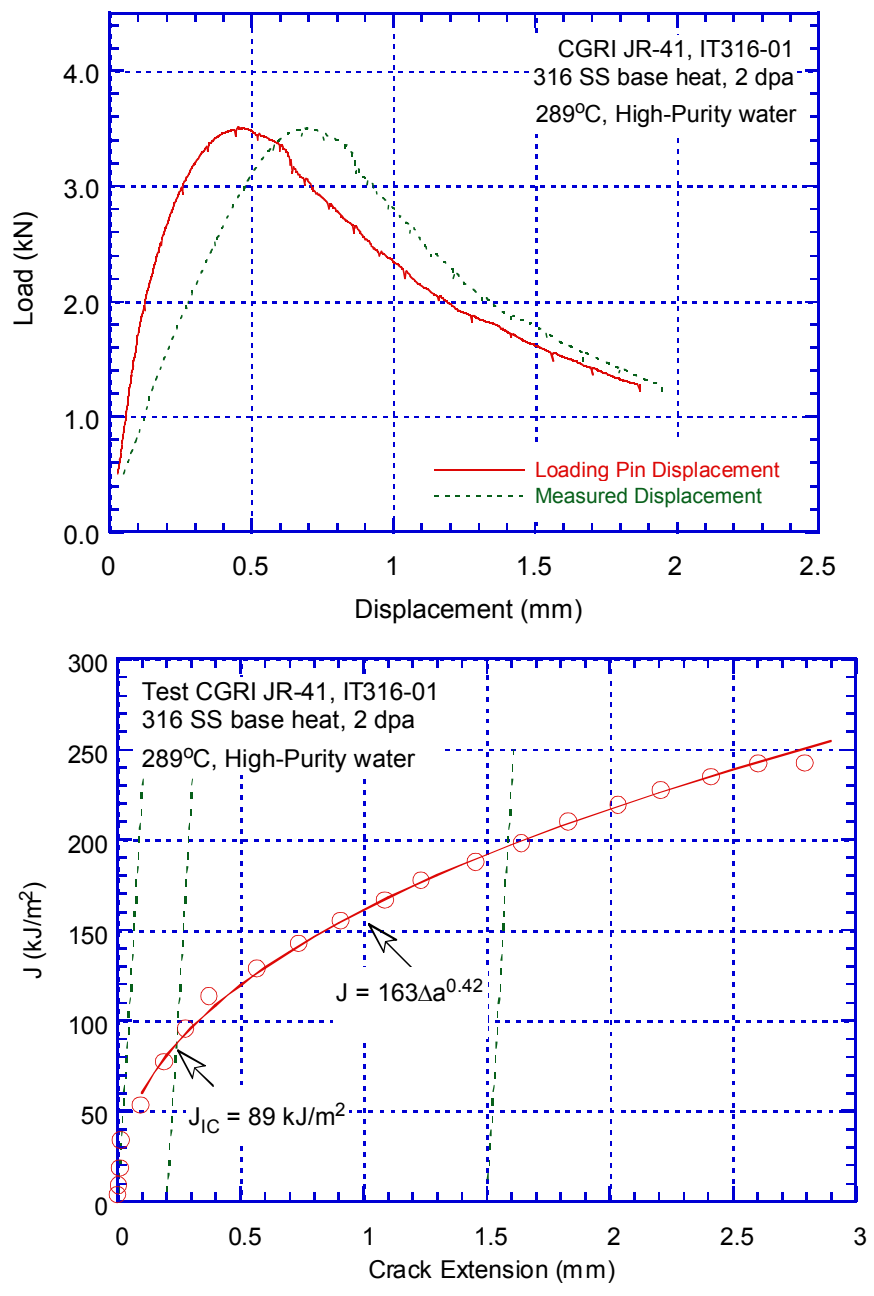

Figure 50. Load vs. load-line displacement curve for the base heat of Type 316 SS (IT316-01) tested in NWC at $289^{\circ} \mathrm{C}$
Figure 51. Fracture toughness J-R curve for the base heat of Type 316 SS (IT316-01) tested in NWC at $289^{\circ} \mathrm{C}$.

After the J-R test, the final crack length was marked by fatigue cycling at room temperature. The specimen was then fractured, and the final crack length of both halves of the fractured specimen was measured from the photograph of the fracture surface (Fig. 52). The actual crack extension was $\approx 6 \%$ greater than the value determined from the DC potential measurements. Crack extensions, estimated from the DC potential method, were adjusted accordingly.

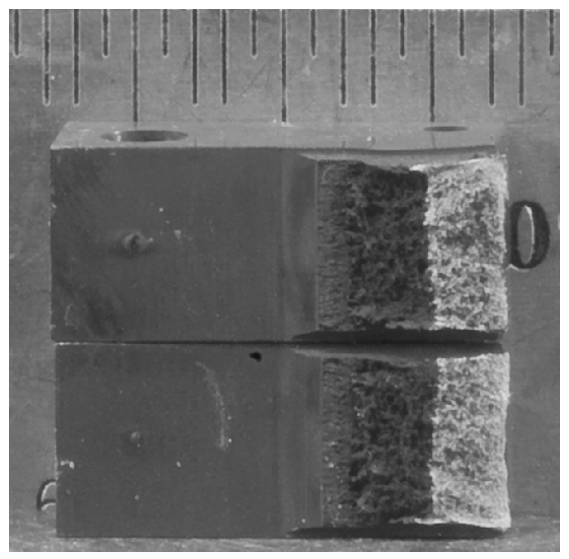

Figure 52. Photograph of the fracture surface of the base heat of Type 316 SS (IT316-01) irradiated to 2 dpa. 


\subsubsection{Type 316 SS with GBE Treatment (GB316-01)}

A CGR test was initiated in BWR water at $289^{\circ} \mathrm{C}$ on a GBE specimen of Type 316 SS (GB316-01) that had been irradiated to $\approx 2 \mathrm{dpa}$ at $290^{\circ} \mathrm{C}$ in the Halden reactor. The test was started in high-purity water with effluent DO content of $\approx 700 \mathrm{ppb}$ and a flow rate of $\approx 20 \mathrm{~mL} / \mathrm{min}$. The specimen was fatigue precracked at $\mathrm{R}=0.25, \mathrm{~K} \max =16-17 \mathrm{MPa} \mathrm{m}^{1 / 2}$, a triangular waveform, and $0.2-1 \mathrm{~Hz}$ frequency. After $\approx 340$ - $\mu \mathrm{m}$ crack advance, $\mathrm{R}$ was increased to $\approx 0.4, \mathrm{Kmax}$ decreased to $\approx 15 \mathrm{MPa} \mathrm{m}^{1 / 2}$, and the waveform was changed to a slow/fast sawtooth with a rise time of $30 \mathrm{~s}$ and a return time of $4 \mathrm{~s}$. Environmental enhancement was not revealed with the change in loading condition; instead, the crack growth stopped. To reestablish crack growth, the $\mathrm{R}$ was decreased, Kmax was increased to $\approx 17 \mathrm{MPa} \mathrm{m}^{1 / 2}$, and frequency increased to $1 \mathrm{~Hz}$. The CGRs were generally lower than those in air under the same loading conditions. Once again, an attempt to increase $\mathrm{R}$ and rise time resulted in insignificant crack growth, and little or no crack growth was noted at load ratios of $0.40-0.55$ and $\Delta \mathrm{K}$ values less than $10 \mathrm{MPa} \mathrm{m}^{1 / 2}$. The Kmax was increased to $\approx 19.5 \mathrm{MPa} \mathrm{m}^{1 / 2}$, and the initial loading sequence was repeated for the third time. Finally, environmental enhancement was observed after $340 \mathrm{~h}$ during test period 10. After the cyclic CGR test, the specimen was tested under constant loads at 18.9 and $16.5 \mathrm{MPa} \mathrm{m}^{1 / 2}$ in test periods 12 and 13 , respectively.

Table 13 summarizes the test conditions and CGR results, and Fig. 53 shows the crack-length-vs.time plots of this GBE-treated Type 316 SS specimen. The cyclic CGRs are plotted in Fig. 54, and environmental enhancement can be seen at around $10^{-9} \mathrm{~m} / \mathrm{s}$. The CGRs for test periods 1,2 , and 6 are not included in Fig. 54 due to insignificant crack growth. Figure 55 shows the constant-load CGRs obtained in this specimen in high-DO $(\approx 600 \mathrm{ppb})$ water. The result from test period 8 is ignored due to insignificant crack extension. The CGRs measured at two constant load conditions are much higher than the NUREG-0313 curve, and this finding suggests a strong irradiation effect on the SCC cracking in this material.

Table 13. Test results for the GBE-treated Type 316 specimen (GB316-01, $\approx 2 \mathrm{dpa}$ ) in BWR water.

\begin{tabular}{|c|c|c|c|c|c|c|c|c|c|c|c|c|c|c|}
\hline \multirow{2}{*}{$\begin{array}{c}\text { Test } \\
\text { Period } \\
\end{array}$} & \multirow{2}{*}{$\begin{array}{c}\text { Test } \\
\text { Time, } \\
\mathrm{h} \\
\end{array}$} & \multirow{2}{*}{$\begin{array}{c}\text { Test } \\
\text { Temp., } \\
{ }^{\circ} \mathrm{C} \\
\end{array}$} & \multicolumn{2}{|c|}{$\begin{array}{c}\text { ECP, }{ }^{\mathrm{a}} \\
\mathrm{mV}(\mathrm{SHE})\end{array}$} & \multirow{2}{*}{$\begin{array}{c}\mathrm{O}_{2} \\
\text { Conc., } \\
\text { ppb } \\
\end{array}$} & \multirow{2}{*}{$\begin{array}{c}\text { R } \\
\text { Load } \\
\text { Ratio }\end{array}$} & \multirow{2}{*}{$\begin{array}{c}\text { Rise } \\
\text { Time, } \\
\mathrm{s} \\
\end{array}$} & \multirow{2}{*}{$\begin{array}{c}\text { Return } \\
\text { Time, } \\
\mathrm{s} \\
\end{array}$} & \multirow{2}{*}{$\begin{array}{c}\text { Hold } \\
\text { Time, } \\
\text { s } \\
\end{array}$} & \multirow{2}{*}{$\begin{array}{c}\mathrm{K}_{\max }, \\
\mathrm{MPa} \mathrm{m}^{1 / 2} \\
\end{array}$} & \multirow{2}{*}{$\begin{array}{c}\Delta \mathrm{K}, \\
\mathrm{MPa} \mathrm{m}^{1 / 2}\end{array}$} & \multirow{2}{*}{$\begin{array}{c}\text { CGR in } \\
\text { Env., } \\
\mathrm{m} / \mathrm{s}\end{array}$} & \multirow{2}{*}{$\begin{array}{c}\text { CGR in } \\
\text { Air, } \\
\text { m/s }\end{array}$} & \multirow{2}{*}{$\begin{array}{c}\text { Crack } \\
\text { Length, } \\
\mathrm{mm}\end{array}$} \\
\hline & & & $\mathrm{Pt}$ & Steel & & & & & & & & & & \\
\hline Pre a & 4 & 288 & 270 & 203 & 700 & 0.25 & 0.44 & 0.44 & $0.06 / 0.06$ & 16.1 & 12.1 & $1.91 \mathrm{E}-08$ & $4.22 \mathrm{E}-08$ & $\begin{array}{l}6.033 \\
6.091\end{array}$ \\
\hline Pre $b$ & 22 & 288 & 271 & 207 & 700 & 0.25 & 0.44 & 0.44 & $0.06 / 0.06$ & 17.1 & 12.8 & $1.13 \mathrm{E}-07$ & $5.15 \mathrm{E}-08$ & 6.316 \\
\hline Pre c & 24 & 288 & 275 & 198 & 700 & 0.26 & 2.2 & 2.2 & $0.3 / 0.3$ & 16.1 & 11.9 & $2.85 \mathrm{E}-08$ & 8.07E-09 & 6.384 \\
\hline 1 & 42 & 288 & 270 & 205 & 700 & 0.42 & 24.6 & 3.3 & $5.4 / 0.7$ & 14.7 & 8.5 & negligible & $2.89 \mathrm{E}-10$ & 6.393 \\
\hline $2 a$ & 52 & 288 & 270 & 206 & 700 & 0.31 & 4.3 & 0.8 & $0.7 / 0.2$ & 15.7 & 10.9 & negligible & $3.28 \mathrm{E}-09$ & 6.396 \\
\hline $2 b$ & 68 & 288 & 271 & 208 & 700 & 0.31 & 4.3 & 0.8 & $0.7 / 0.2$ & 15.6 & 10.7 & negligible & $3.14 \mathrm{E}-09$ & 6.402 \\
\hline $2 \mathrm{c}$ & 77 & 288 & 272 & 209 & 700 & 0.33 & 0.85 & 0.85 & $0.15 / 0.15$ & 15.9 & 10.7 & negligible & $1.61 \mathrm{E}-08$ & 6.408 \\
\hline 3 & 95 & 288 & 272 & 210 & 700 & 0.26 & 0.44 & 0.44 & $0.06 / 0.06$ & 18.4 & 13.6 & 4.19E-08 & $6.31 \mathrm{E}-08$ & 6.562 \\
\hline 4 & 100 & 288 & 272 & 210 & 700 & 0.28 & 2.2 & 2.2 & $0.3 / 0.3$ & 18.8 & 13.5 & $1.79 \mathrm{E}-08$ & $1.26 \mathrm{E}-08$ & 6.690 \\
\hline 5 & 114 & 289 & 271 & 210 & 700 & 0.39 & 8.5 & 1.7 & $1.5 / 0.3$ & 20.2 & 12.2 & $1.09 \mathrm{E}-08$ & $2.68 \mathrm{E}-09$ & 7.047 \\
\hline $6 a$ & 139 & 290 & 270 & 210 & 700 & 0.49 & 39.8 & 3.2 & $10.2 / 0.8$ & 17.3 & 8.8 & negligible & $2.13 \mathrm{E}-10$ & 7.052 \\
\hline $6 \mathrm{~b}$ & 161 & 290 & & & 700 & 0.49 & 40.6 & 3.2 & $9.4 / 0.8$ & 19.2 & 9.7 & $6.89 \mathrm{E}-11$ & $2.91 \mathrm{E}-10$ & 7.065 \\
\hline 7 & 174 & 287 & 273 & 213 & 700 & 0.41 & 4.2 & 1.7 & $0.8 / 0.3$ & 19.7 & 11.5 & $5.94 \mathrm{E}-10$ & 4.54E-09 & 7.090 \\
\hline 8 & 217 & 288 & 280 & 220 & 700 & 1.0 & - & - & - & 20.0 & - & $3.56 \mathrm{E}-10$ & - & 7.096 \\
\hline 9 & 330 & 288 & 257 & 199 & 600 & 0.43 & 8.30 & 8.3 & $1.7 / 1.7$ & 20.1 & 11.5 & $1.27 \mathrm{E}-09$ & 2.32E-09 & 7.223 \\
\hline 10 & 377 & 288 & 256 & 196 & 600 & 0.43 & 81.2 & 9.7 & $18.8 / 2.3$ & 19.0 & 10.8 & $1.52 \mathrm{E}-09$ & $1.92 \mathrm{E}-10$ & 7.364 \\
\hline 11 & 387 & 288 & 255 & 195 & 600 & 0.48 & 398 & 9.5 & $102 / 2.5$ & 18.5 & 9.7 & $6.08 \mathrm{E}-10$ & $2.90 \mathrm{E}-11$ & 7.379 \\
\hline 12 & 404 & 288 & 255 & 195 & 600 & 0.98 & - & - & - & 18.9 & 0.4 & $9.04 \mathrm{E}-10$ & - & 7.437 \\
\hline 13 & 426 & 288 & 255 & 195 & 600 & 0.98 & - & - & - & 16.5 & 0.3 & $7.57 \mathrm{E}-10$ & - & 7.499 \\
\hline
\end{tabular}

$\mathrm{b}$ Hold periods at minimum load during the loading cycle and at maximum load during the unloading cycle 


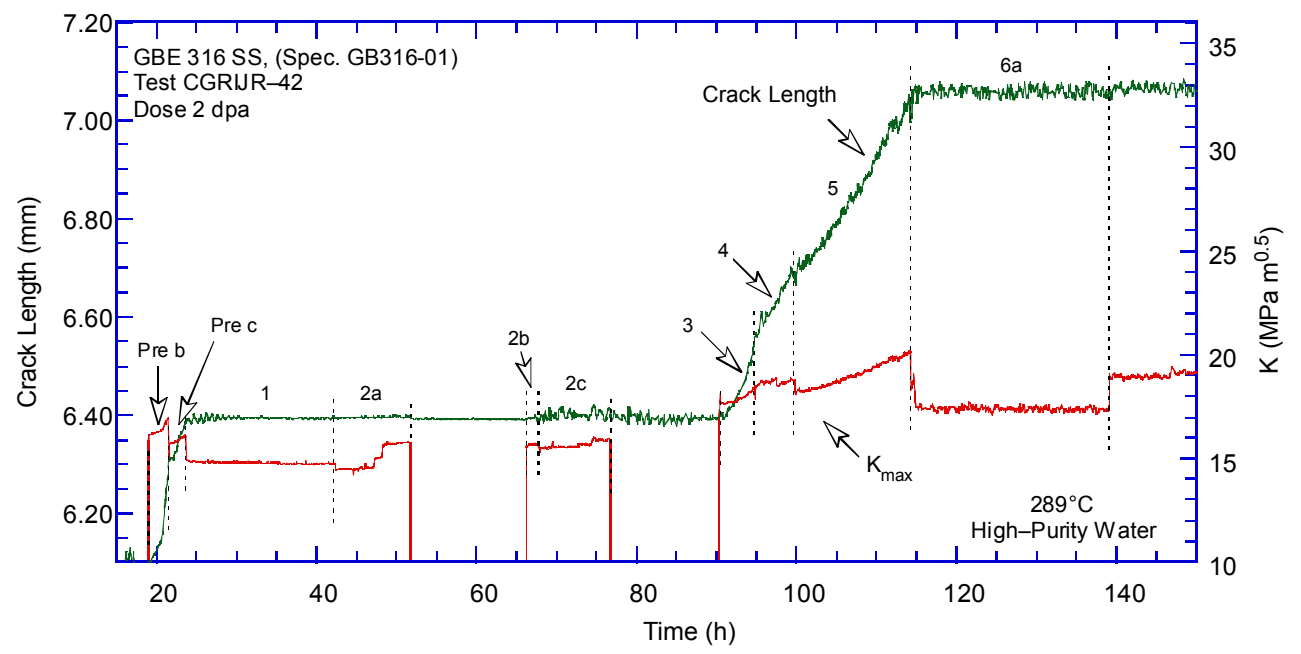

(a)

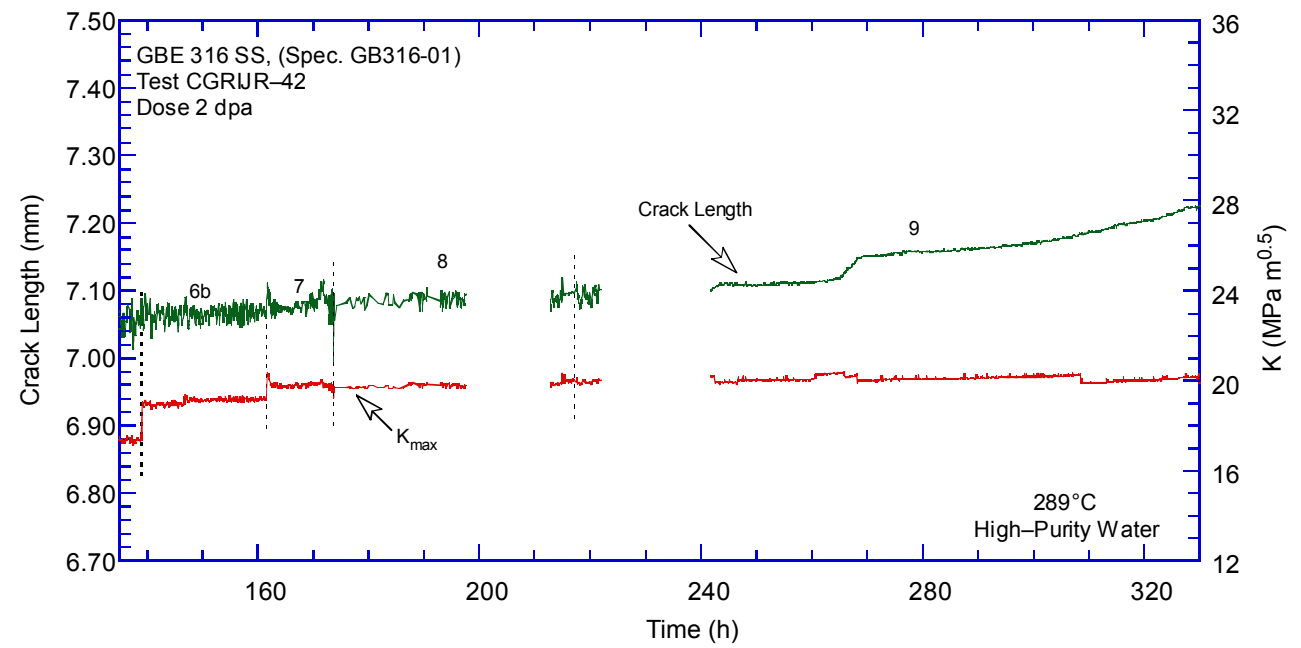

(b)

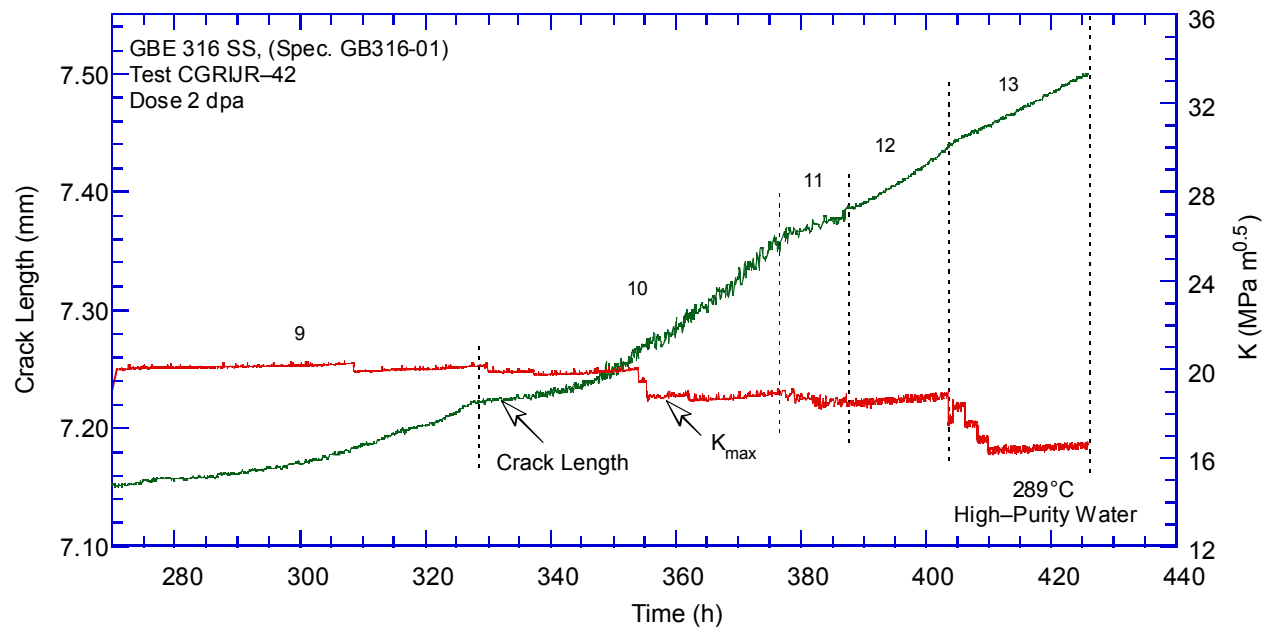

(c)

Figure 53. Crack-length-vs.-time plot for the GBE-treated Type 316 SS (GB316-01, ₹2 dpa) tested in BWR water at $289^{\circ} \mathrm{C}$. 

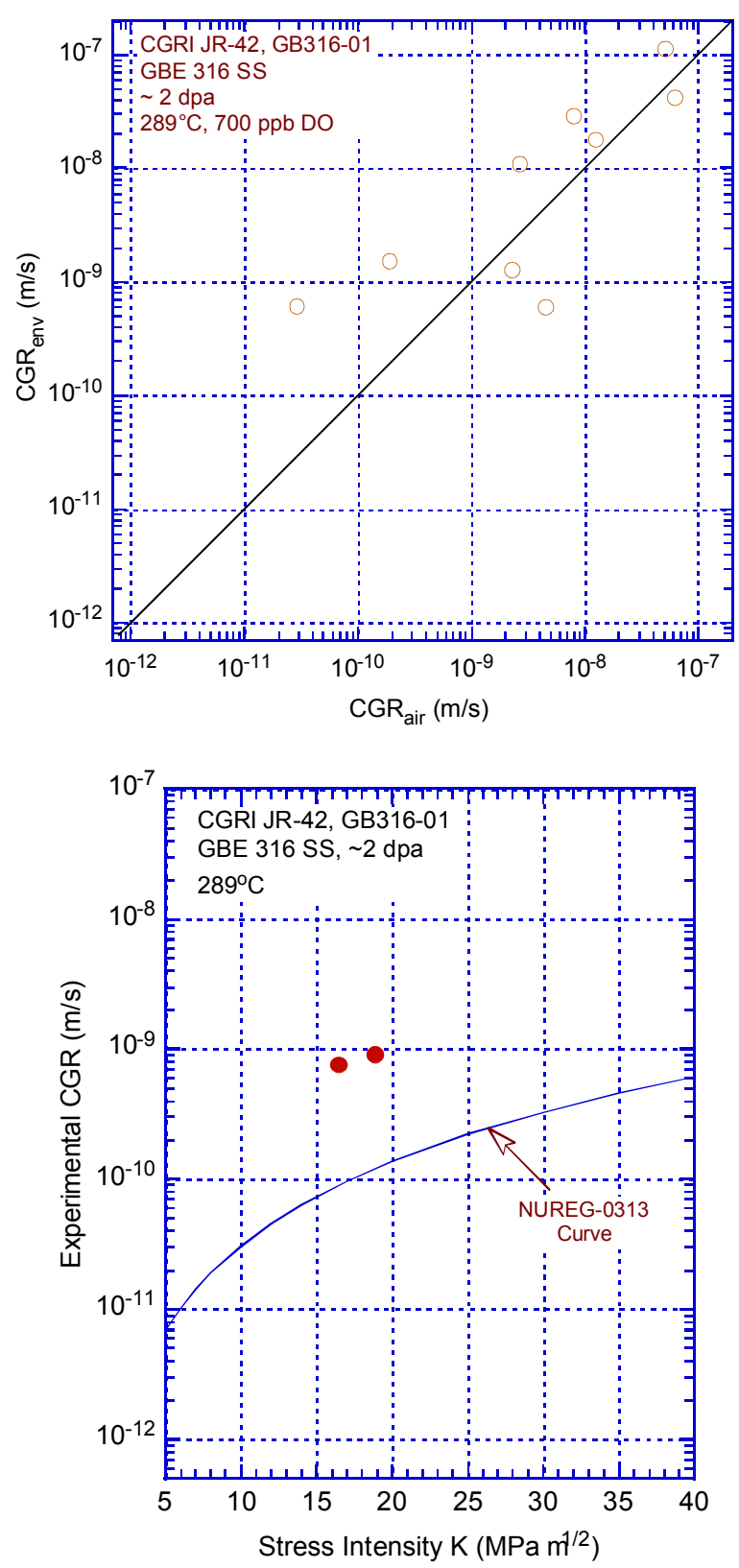

Figure 54. Cyclic CGR for the GBE-treated Type 316 SS (GB316-01) irradiated to 2 dpa.
Figure 55. Crack growth rate versus stress intensity under constant-loading conditions for the GBE-treated Type 316 SS (GB316-01) irradiated to 2 dpa.

After the CGR test, a J-R curve test was performed on the GBE 316 SS specimen at $289^{\circ} \mathrm{C}$ in highDO water $(\approx 600 \mathrm{ppb} D O)$. The test was conducted at a constant extension rate of $0.43 \mu \mathrm{m} / \mathrm{s}$. The test was interrupted periodically to measure crack length by DCPD measurements. The obtained load vs. load-line displacement curve is shown in Fig. 56, and the corresponding J-R curve is shown in Fig. 57. A relatively high fracture toughness was obtained for this specimen with a $\mathrm{J}_{\mathrm{IC}}$ of about $178 \mathrm{~kJ} / \mathrm{m}^{2}$. 

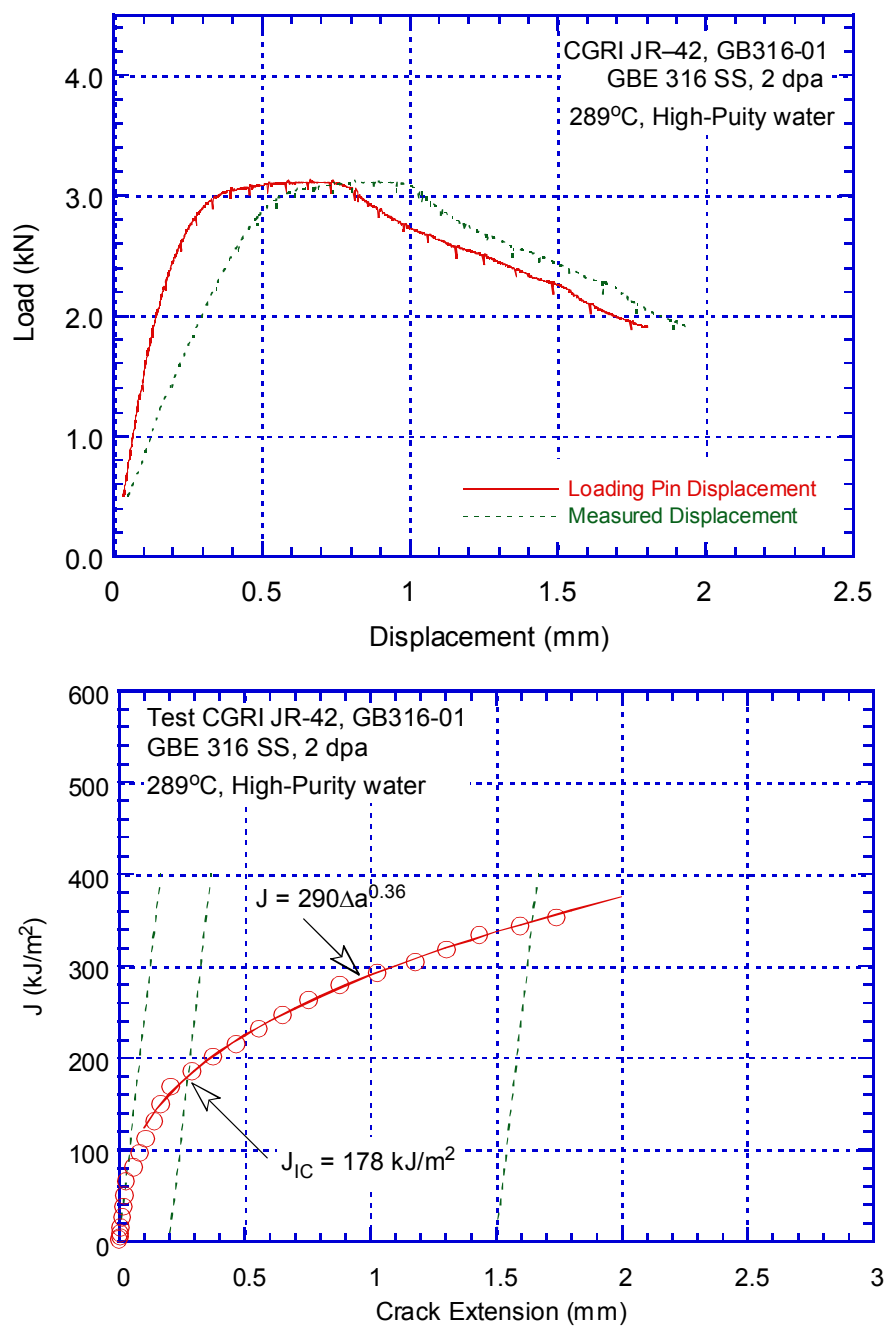

Figure 56. Load vs. load-line displacement curve for the GBE-treated Type 316 SS (GB316-01, $\approx 2$ dpa) tested in NWC at $289^{\circ} \mathrm{C}$.

Figure 57. Fracture toughness J-R curves for the GBE-treated Type 316 SS (GB316$01, \approx 2 \mathrm{dpa}$ ) tested in NWC at $289^{\circ} \mathrm{C}$.

Following the J-R test, the final crack length was marked by fatigue cycling at room temperature in air. The specimen was then fractured, and the final crack length of both halves of the fractured specimen was measured from the photograph of the fracture surface (Fig. 58). The actual crack extension was $\approx 4 \%$ greater than the value determined from the DCPD measurements. Crack extensions, estimated from the DCPD method, were adjusted accordingly.

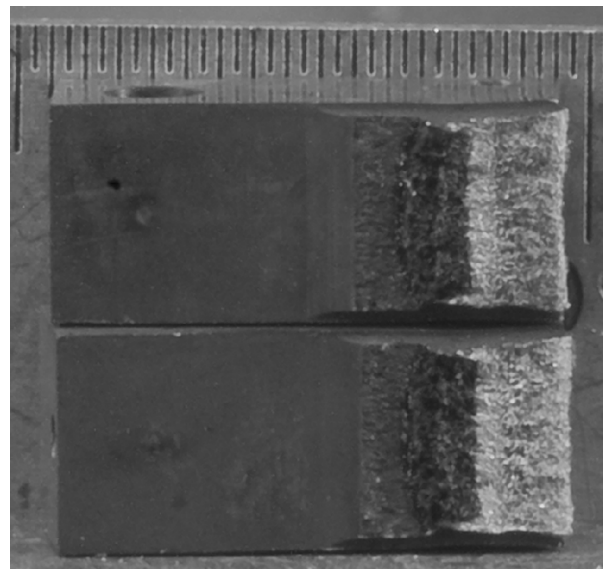

Figure 58. Photograph of the fracture surface of the GBE-treated Type 316 SS (GB316-01) irradiated to 2 dpa. 
This page is intentionally left blank. 


\section{Discussion}

In addition to the data presented in Section 3, the test results from previous Halden-II tests 20 are considered in this section to derive an overall view of IASCC susceptibility. The effects of neutron dose, water chemistry, alloy type, and welding and processing conditions on IASCC behavior are discussed. The influence of neutron irradiation on the fracture toughness of austenitic SSs, weld HAZs, and a cast SS material is also presented.

\subsection{Specimen Size Criteria Relevant to Cyclic and Constant-Load CGR Tests}

Before the test results can be used to evaluate the IASCC behavior, loading conditions in the crack growth rate test need to be validated. Both cyclic and constant-load CGR tests are intended to be performed under a $K$-dominated condition in which the stress intensity factor $(\mathrm{K})$ defines the amplitude of the crack-tip singularity. ${ }^{53-55}$ If $\mathrm{K}$ characterizes the crack-tip loading conditions (stress and strain) adequately, the test results will be independent of sample size or geometry, even for materials that exhibit plastic deformation. Stress-intensity-factor dominance implies that the plastic zone ahead of the crack front must be small compared to all length dimensions in a test specimen. For a given specimen geometry, the applied load must be less than a limiting value to ensure that a relatively small plastic zone ahead of the crack tip can be embedded within a largely elastic body of the test specimen.

It is well documented that the plastic zone size is proportional to the square of the ratio between the stress intensity factor and the yield strength $\left(\mathrm{K} / \sigma_{\mathrm{y}}\right)^{2} .56,57$ Using an elastic-perfect-plastic model, Irwin estimated that the size of plastic zone as 58

$$
\mathrm{r}_{\mathrm{p}}=\frac{1}{\pi}\left(\frac{\mathrm{K}}{\sigma_{\mathrm{y}}}\right)^{2}
$$

Comparing Eq. (3) and Eq. (19) indicates that the required specimen dimensions (thickness and remaining ligament) are at least a factor of $\approx 8$ greater than the plastic zone size. For a given specimen, the upper limit of $\mathrm{K}$ to ensure a $\mathrm{K}$-dominated test condition is

$$
\mathrm{K}_{\text {limit }} \leq 0.63 \cdot \sigma_{\mathrm{y}} \cdot[\mathrm{B}, \text { or }(\mathrm{W}-\mathrm{a})]^{1 / 2}
$$

For strain-hardening materials, such as austenitic SSs, more stress can be carried by the plastically deformed region than that in an elastic-perfect-plastic material. Thus, the actual plastic zone size is smaller than that given by Eq. (19), if $\sigma_{\mathrm{y}}$ is interpreted as the initial yield stress. For this reason, the flow stress, which is defined as the average of yield strength and ultimate tensile stress, can be used in Eq. (20) instead of $\sigma_{\mathrm{y}}$ without compromising the K-dominated test condition.

The picture is more complex in irradiated materials. While neutron irradiation increases yield strength significantly, it affects the strain hardening behavior as well. For specimens irradiated to lowdoses, strain hardening remains to some extent. This finding suggests that higher far-field applied stresses should be allowed for testing of low-dose irradiated specimens compared with nonirradiated specimens. In contrast, strain softening often occurs in high-dose specimens due to dislocation channeling. Because the plastic zone size can be affected by strain softening, the allowable K for CGR tests could be lower for strain-softened materials. 
Several authors 59,60 have contended that the K/size criterion specified in Eq. (3) or Eq. (20), where $\sigma_{\mathrm{y}}$ is taken as the yield strength of the irradiated material, is inadequate due to irradiation-induced strain softening. Numerous SCC experiments have indeed shown a K-size effect on CGRs when strain hardening is absent. 61,62 To account for the strain softening, an effective yield strength $\left(\sigma_{\text {eff }}\right)$ has been proposed to replace $\sigma_{\mathrm{y}}$ in Eq. (3). The use of the average or one-third the irradiated and nonirradiated yield strengths seems to work well for some experimental data. ${ }^{59,60}$ However, the use of the yield strength of the nonirradiated material in determining the allowable plastic zone size in an irradiated specimen is questionable from a purely mechanics perspective.

A simple model, shown in Fig. 59, is proposed in this study to account for the strain-softening effect in irradiated materials. If an irradiated material that exhibits work-softening behavior has a monotonic yield strength $\sigma_{\mathrm{y} \text {-irr }}$ and a reduced stress $\sigma_{\mathrm{s} \text {-irr }}$ beyond yield, then, according to the elastic theory, the stress released in the yield region ahead of the crack tip is

$$
\sigma=\frac{\mathrm{K}}{\sqrt{2 \pi \cdot \mathrm{r}_{\mathrm{y}}}}
$$

where $r_{y}$ is the size of the yielding zone. The released stress must be redistributed in a large area that is defined by $r_{p}$. Thus,

$$
\frac{\sigma_{\mathrm{y}-\mathrm{irr}}+\sigma_{\mathrm{s}-\mathrm{irr}}}{2} \cdot \mathrm{r}_{\mathrm{p}}=\int_{0}^{\mathrm{r}_{\mathrm{y}}} \frac{\mathrm{K}}{\sqrt{2 \pi \cdot \mathrm{r}}} \cdot \mathrm{dr}
$$

Integrating Eq. (22) and solving for $r_{p}$ give

$$
\mathrm{r}_{\mathrm{p}}=\frac{2}{\pi} \cdot \frac{\mathrm{K}^{2}}{\sigma_{\mathrm{y}-\mathrm{irr}}\left(\sigma_{\mathrm{y}-\mathrm{irr}}+\sigma_{\mathrm{s}-\mathrm{irr}}\right)}
$$

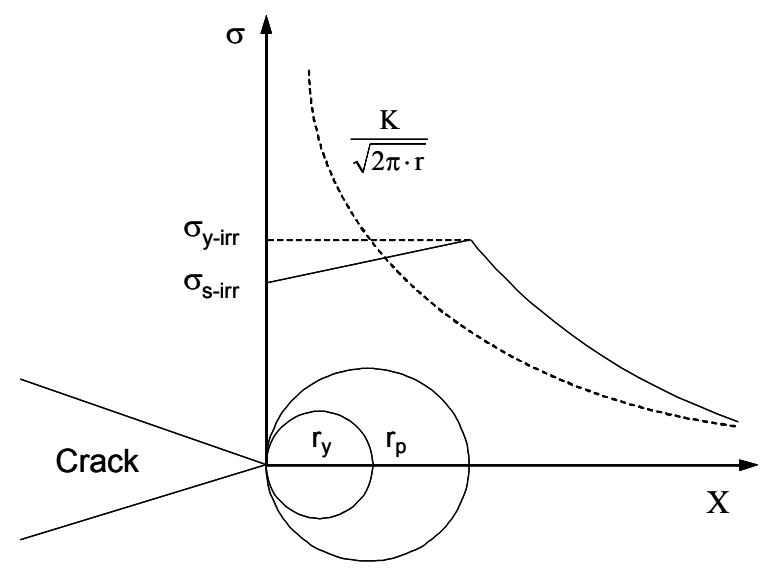

Figure 59. Stress distribution ahead of a two-dimensional crack in a work-softened material.

The reduced far-field stress beyond the yield point $\sigma_{\mathrm{s} \text {-irr }}$ should be distinguished from the final fracture stress $\left(\sigma_{f}\right)$ beyond necking. Without the normal plastic instability (necking) exhibited in a monotonic tensile test, the far-field stress due to strain-softening $\left(\sigma_{\mathrm{y}-\text { irr }}-\sigma_{\mathrm{s} \text {-irr }}\right)$ is not greatly reduced in an irradiated material. Assuming a $20 \%$ reduction in this far-field stress, that is $\sigma_{\mathrm{S} \text {-irr }}=0.8 \sigma_{\mathrm{y}-\mathrm{irr}}$, the 
plastic zone size is only $\approx 11 \%$ larger than that predicted by Eq. (3) using $\sigma_{y-i r r}$. In most cases, the strain softening exhibited in irradiated materials is not more than a few percent of their yield strength $\left(\sigma_{\mathrm{y}-i r r}\right)$. Thus, the plastic zone size with and without consideration of strain softening should be similar. Several experimental and finite element method (FEM) studies have confirmed that the plastic zone size is not strongly affected by strain-softening behavior in irradiated materials. ${ }^{63,64}$ This observation agrees with the simple analysis presented above. Whether or not a K-dominated condition is satisfied in a CGR test should be determined by Eq. (3) or Eq. (20) using the irradiated yield strength ( $\left.\sigma_{y \text {-irr }}\right)$. As pointed out previously, this criterion is a very strict requirement to ensure a small-scale yielding condition ahead of a crack. ${ }^{47}$ The specimen-size effects observed in SCC experiments could be attributed to non-mechanical factors (e.g., crack tip chemistry and deformation behavior).

\subsection{Effects of Weld Process on Cracking Behavior}

\subsubsection{Cyclic CGR for Nonirradiated Weld HAZs}

The present study tested HAZ specimens made from Type 304L SA weld as well as Type 304 SMA weld (Table 4). The cracking behavior of nonirradiated specimens of these materials needs to be evaluated to establish a baseline for studying IASCC susceptibility. For CGR tests performed on 1/4TCT specimens, the K-dominated test condition is likely to be violated in nonirradiated tests because of the low yield strength exhibited in nonirradiated materials. In fact, none of the cyclic CGR tests performed on the nonirradiated weld HAZ specimens met the K/size criterion specified by Eq. (3). However, loading conditions for most of these data points did satisfy the criterion for fatigue crack propagation tests that was detailed in ASTM E-647. A predominantly elastic behavior of specimens in fatigue tests was ensured by:

$$
\mathrm{W}-\mathrm{a} \geq \frac{4}{\pi}\left(\frac{\mathrm{K}_{\max }}{\sigma_{\mathrm{y}}}\right)^{2}
$$

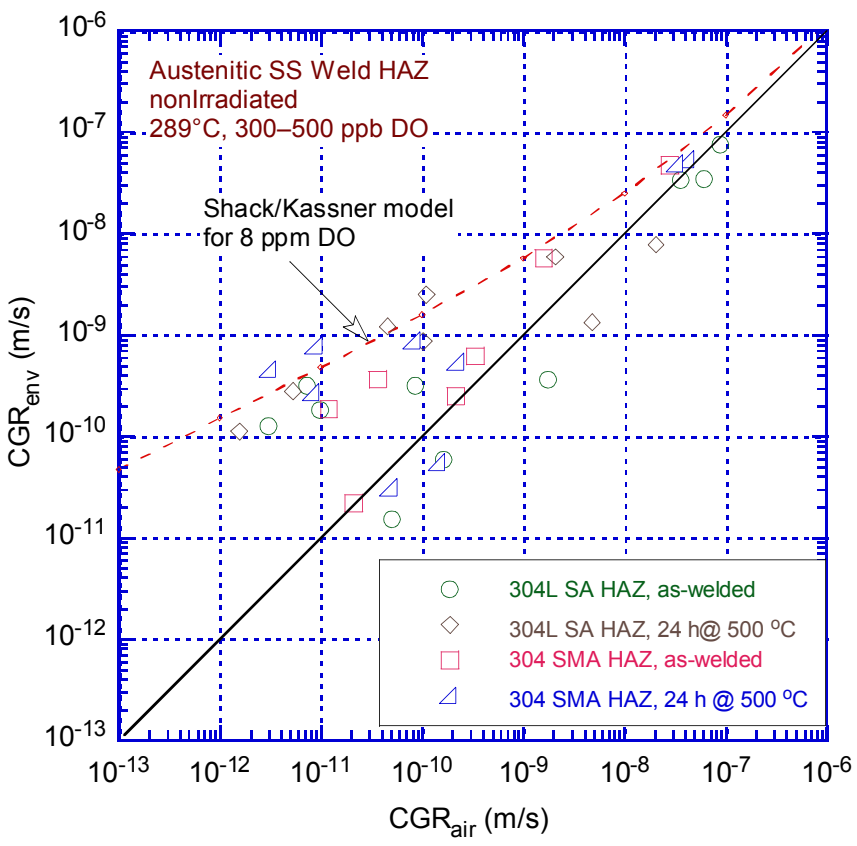

Figure 60. Cyclic CGRs for nonirradiated SA and SMA weld HAZ specimens under the as-welded and thermally treated conditions. ${ }^{19}$ 
Figure 60 shows cyclic data from nonirradiated SA and SMA weld HAZ specimens. Environmental effects can be seen for all specimens. The curve for environmentally enhanced cracking represented by the Shack and Kassner model ${ }^{48}$ for the case of 8 ppm DO water is also shown in the figure. A slightly higher environmental enhancement can be seen in the HAZ specimens with post-weld heat treatment.

\subsubsection{Cyclic CGR for Irradiated Weld HAZ Materials}

Cyclic CGRs for irradiated SA and SMA HAZ specimens were measured at two dose levels, $\approx 0.75$ dpa and $\approx 2$ dpa. ${ }^{19,20}$ Thanks to irradiation hardening, all CGR tests performed at these dose levels can meet even the K-size criterion specified by Eq. (3). Figure 61a shows cyclic CGR results for aswelded SA and SMA HAZ specimens at $0.75 \mathrm{dpa}$, a proposed threshold dose level for IASCC in BWR internal components. Environmentally enhanced cracking was achieved easily at this dose level for both types of weld HAZ materials under the as-welded condition. The susceptibility to SCC was elevated considerably by irradiation. No difference in cyclic CGRs can be seen between SA and SMA weld HAZ materials. The rate of cracking generally settled at around 5 to $7 \times 10^{-10} \mathrm{~m} / \mathrm{s}$ in simulated BWR NWC water at $\approx 290^{\circ} \mathrm{C}$. At $\approx 2 \mathrm{dpa}$, the cyclic CGRs were also similar for both weld HAZ materials (as shown in Fig. 61b). The effect of environmental enhancement was slightly greater at the higher dose, and the observed cyclic CGRs were close to $10^{-9} \mathrm{~m} / \mathrm{s}$.

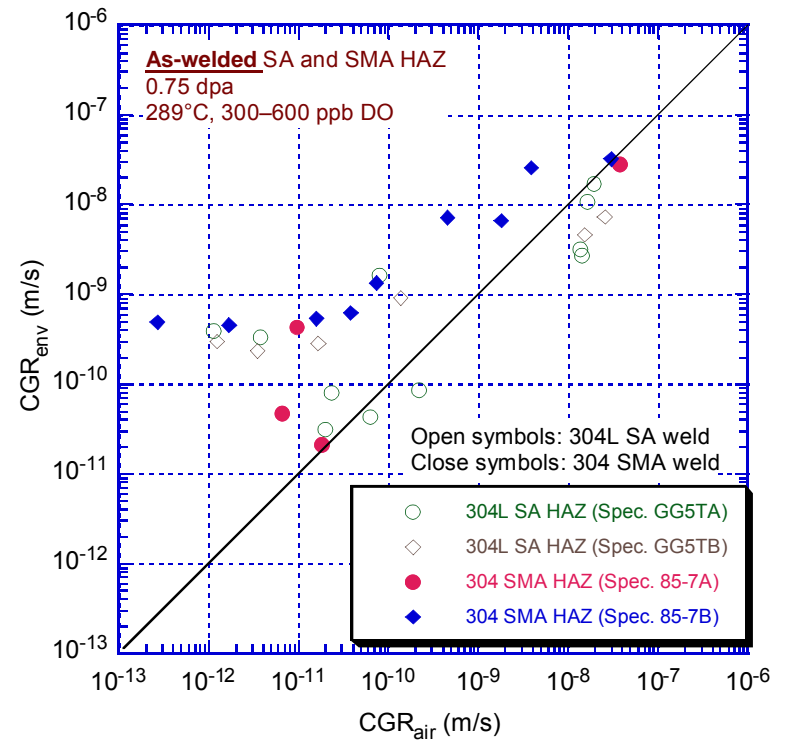

(a)

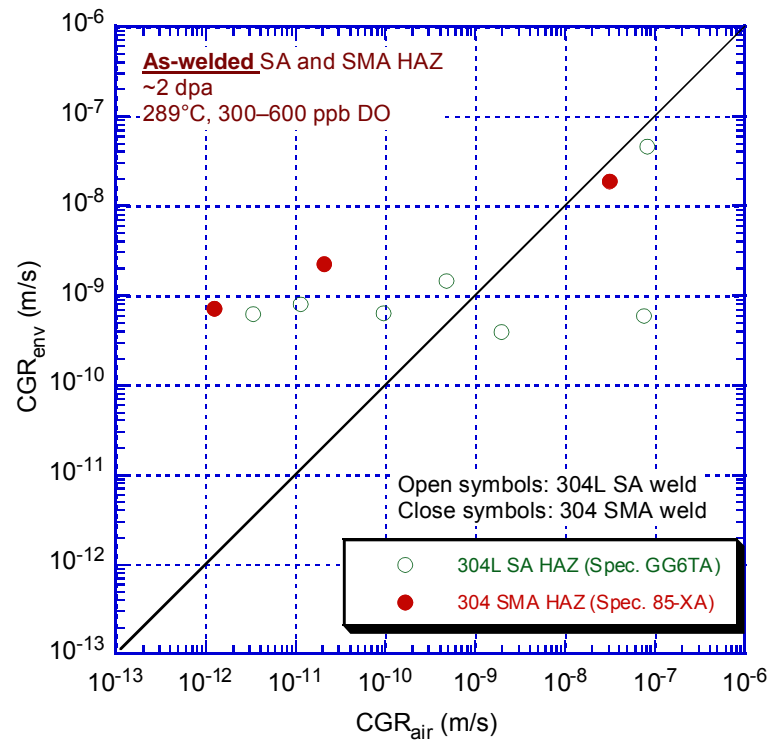

(b)

Figure 61. Cyclic CGRs for SA and SMA weld HAZ specimens under as-welded condition irradiated to (a) $0.75 \mathrm{dpa}$, and (b) $\approx 2 \mathrm{dpa}$.

To simulate low-temperature sensitization, both SA and SMA welds were thermally treated at $500^{\circ} \mathrm{C}$ for $24 \mathrm{~h}$ prior to irradiation. Figure 62 shows the cyclic CGRs for weld HAZ specimens under the as-welded and thermally treated conditions. Comparisons are made at 0.75 dpa for 304 SMA weld and at $\approx 2 \mathrm{dpa}$ for 304L SA weld. No obvious difference was detected between as-welded and thermally treated CGR results for both types of welds. This observation suggests that, at the present dose level, the low- 
temperature sensitization does not have a significant effect on IASCC susceptibility of SA and SMA weld HAZ specimens.

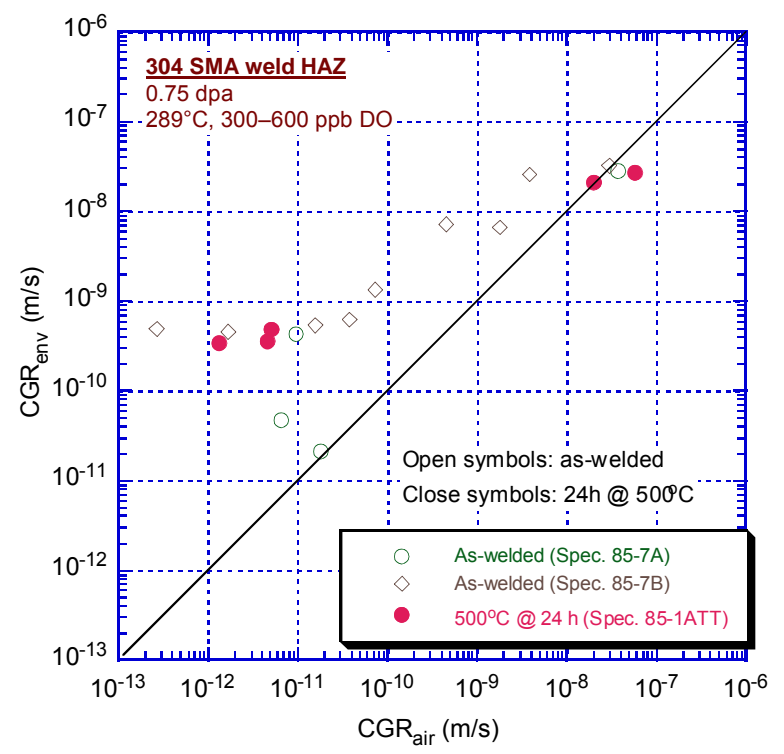

(a)

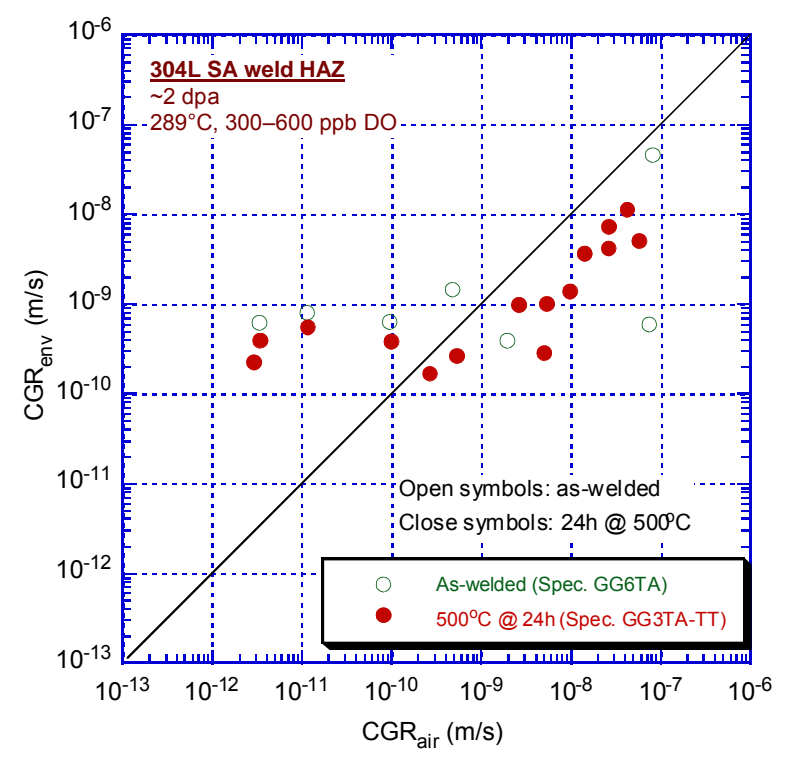

(b)

Figure 62. Cyclic CGRs for thermally treated and as-welded (a) SMA HAZ specimens at 0.75 dpa and (b) SA HAZ specimens at 2 dpa.

\subsubsection{Constant-Load CGR for Nonirradiated and Irradiated Weld HAZ Specimens}

Figure 63 shows CGR results for nonirradiated SA and SMA HAZ specimens with and without heat treatment under constant-load conditions with periodical unloading. ${ }^{19}$ The green symbols are data points for 304L SA welds, and the brown symbols are for 304 SMA welds. For nonirradiated 1/4T-CT specimens, the K-size criterion was not satisfied for any of the data points shown in Fig. 63. Therefore, caution must be exercised when comparing these data with other CGR results.

The constant-load CGRs of nonirradiated SA and SMA HAZ specimens (except one data point) is bounded by the NUREG-0313 curve that was developed based on sensitized SSs in oxygenate water (8 ppm DO). ${ }^{50}$ For the 304L SA weld HAZ specimens (diamond symbols), SCC CGRs in high-DO water are about two times lower than the NUREG- 0313 curve. Heat treatment at $500^{\circ} \mathrm{C}$ for $24 \mathrm{~h}$ did not affect the cracking behavior under constant load. While SCC CGR data for the as-welded 304 SMA HAZ specimen are unavailable in NWC, CGRs of the as-welded HAZ specimen in HWC are about 2-5 times lower than the NUREG-0313 curve, similar to the values exhibited by the 304L SA HAZ specimen under NWC.

Figure 64 shows the constant-load CGR results for irradiated SA and SMA HAZ specimens. With irradiated yield strength, all data reported in Fig. 64 are validated for the K/size criterion specified in Eq. (3). A significant increase in constant-load CGR can be seen for all weld HAZ specimens with NWC after irradiation. At $0.75 \mathrm{dpa}$, constant-load CGRs for the HAZ materials of the SA and SMA welds in NWC are 8-10 times higher than the NUREG-0313 curve (Fig. 64a). The cracking behavior of the 304L SA HAZ and 304 SMA HAZ are very similar under the as-welded condition. The constant-load CGRs of thermally treated 304 SMA HAZ is lower but still significantly higher than the NUREG-0313 curve. At $\approx 2$ dpa, constant-load CGRs for as-welded SA and SMA HAZ in NWC are similar and are about eight 
times higher than the NUREG-0313 curve. Thermally treatment, at $500^{\circ} \mathrm{C}$ for $24 \mathrm{~h}$, had no effect on the IASCC susceptibility of 304L SA HAZ. For both neutron doses, the beneficial effect of HWC is evident. Except for thermally treated 304 SMA HAZ, CGRs measured in HWC are more than one order of magnitude lower than that in NWC. For both neutron doses, the constant-load CGRs in HWC are all below the NUREG-0313 curve, regardless of weld type and post-weld heat treatment.

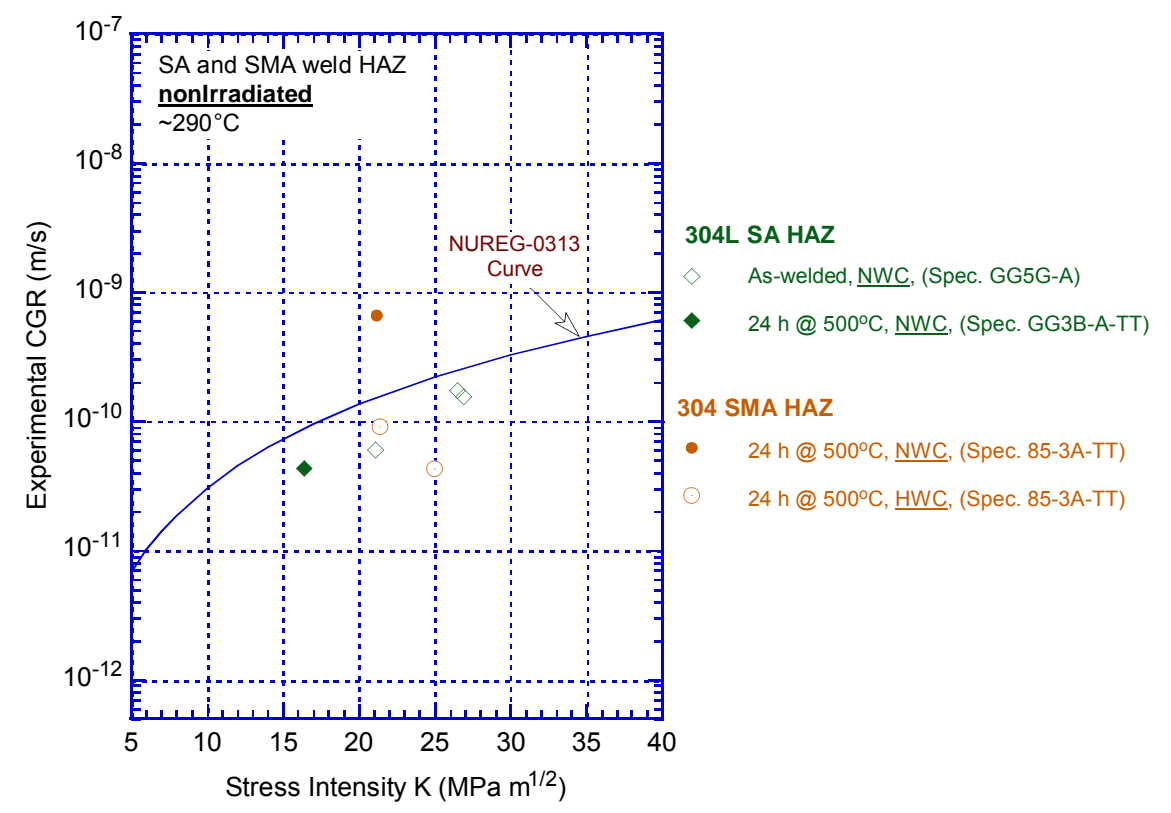

Figure 63. Constant-load CGR versus stress intensity for nonirradiated SA and SMA weld HAZ specimens with and without heat treatment.

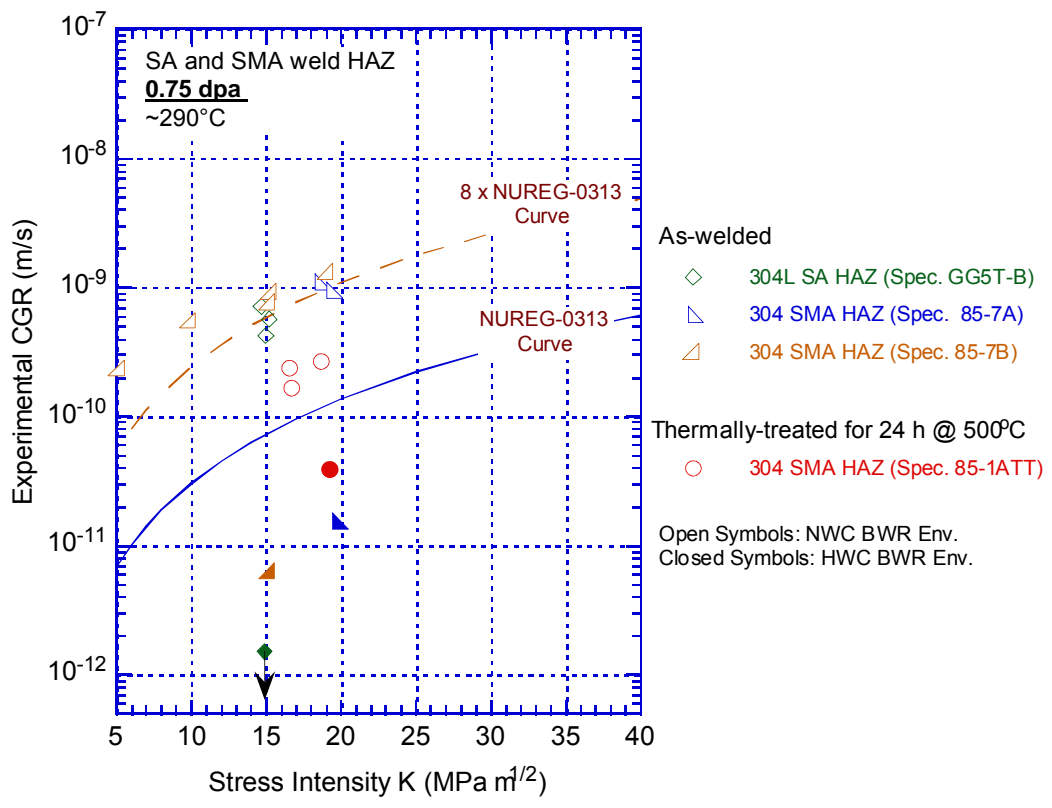

(a)

Figure 64. Constant-load CGR results versus stress intensity for SA and SMA HAZ specimens irradiated to (a) $0.75 \mathrm{dpa}$ and (b) $\approx 2 \mathrm{dpa}$ 


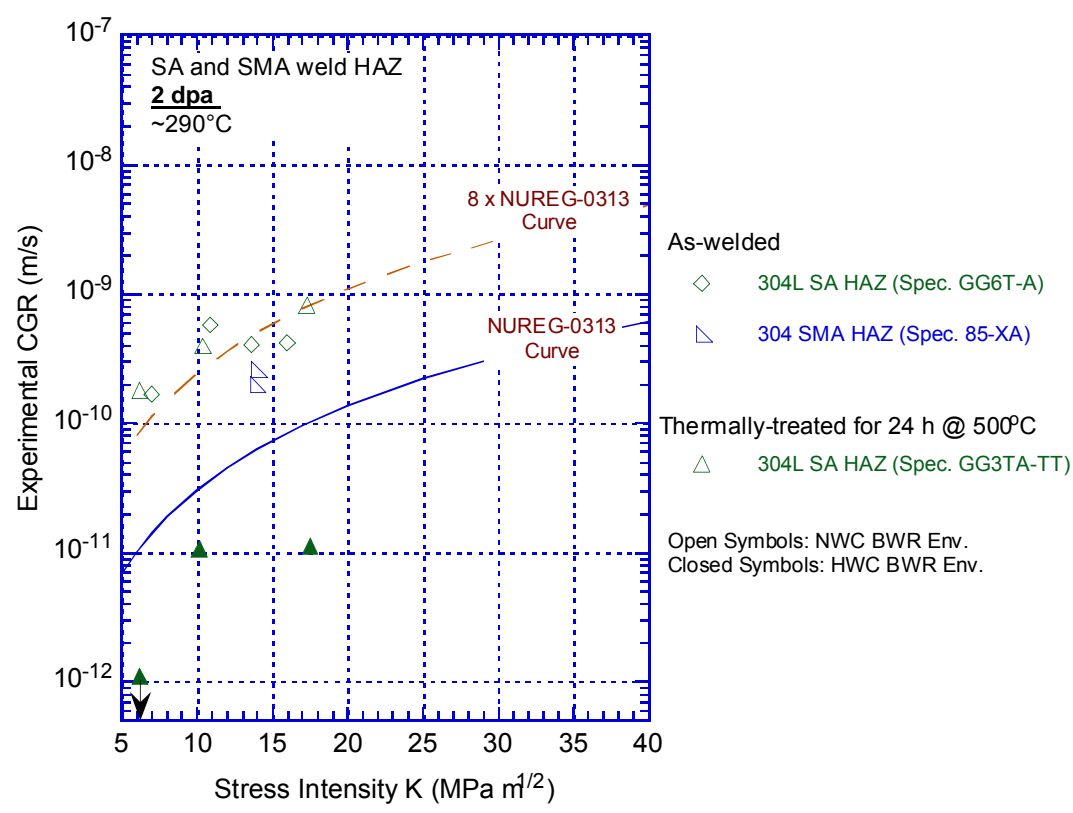

Figure 64. (Contd.)

(b)

\subsubsection{Fracture Toughness of Weld HAZ Specimens}

At around $300^{\circ} \mathrm{C}$, fracture toughness for nonirradiated austenitic SSs is reported to be in the range of $200-600 \mathrm{~kJ} / \mathrm{m}^{2}$. ${ }^{65-67}$ Weld process and neutron irradiation both result in significant reductions in fracture toughness by introducing new embrittlement mechanisms. In the present study, fracture toughness measured in NWC BWR water was found to be similar between the SA and SMA HAZ specimens under the as-welded condition (Fig. 65). The $\mathrm{J}_{\mathrm{IC}}$ for the Type 304 SMA HAZ is about 94 $\mathrm{kJ} / \mathrm{m}^{2}$ (specimen $85-7 \mathrm{~B}$ ) and $98 \mathrm{~kJ} / \mathrm{m}^{2}$ (specimen $85-\mathrm{XA}$ ) at 0.75 and 2 dpa respectively, and the $\mathrm{J}_{\mathrm{IC}}$ for the Type $304 \mathrm{~L}$ SA HAZ is about $108 \mathrm{~kJ} / \mathrm{m}^{2}$ (specimen GG-6TA) at $\approx 2$ dpa. Post-weld heat treatment at $500^{\circ} \mathrm{C}$ for $24 \mathrm{~h}$ reduces the fracture toughness of the $304 \mathrm{~L}$ SA HAZ from $108 \mathrm{~kJ} / \mathrm{m}^{2}$ to $73 \mathrm{~kJ} / \mathrm{m}^{2}$ (specimen GG3TA-TT). For the 304 SMA HAZ, the $\mathrm{J}_{\mathrm{IC}}$ of the heat-treated specimen is significantly lower, approximately $34 \mathrm{~kJ} / \mathrm{m}^{2}$ (specimen $85-2 \mathrm{ATT}$ ). The fracture toughness obtained in these HAZ specimens is comparable or slightly lower than that of other austenitic SSs irradiated to the same dose level. 


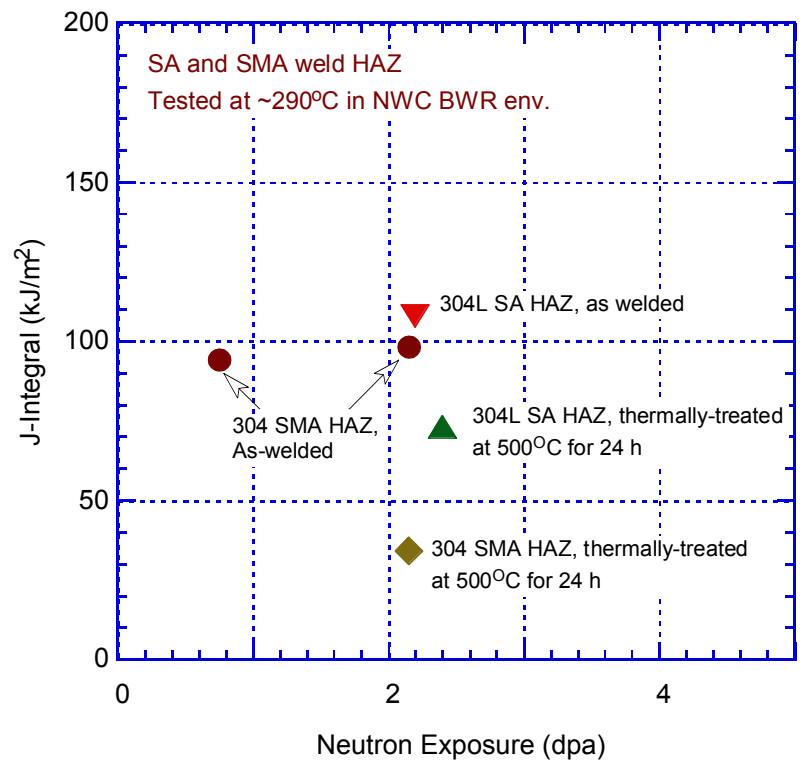

Figure 65. Fracture toughness of irradiated Type 304L SA and 304 SMA weld HAZ specimens tested in NWC BWR water.

\subsection{Effect of Sensitization}

Type $304 \mathrm{SS}$ specimens thermally sensitized at $600^{\circ} \mathrm{C}$ for 10.5 and $24 \mathrm{~h}$ were included in the present study. The specimens were irradiated to two dose levels, 0.75 and 2 dpa, prior to being tested in the simulated BWR water environment. Figure 66 shows the cyclic CGR results for these sensitized specimens in NWC. In general, environmental enhancement of CGRs was readily achieved in the sensitized specimens at both dose levels. Elevated growth rates were observed at around $\approx 10^{-9} \mathrm{~m} / \mathrm{s}$ for the 0.75 -dpa specimens. Slightly higher cracking rates were observed in the 2-dpa specimen. For the two sensitization conditions $\left(600^{\circ} \mathrm{C}\right.$ for $10.5 \mathrm{~h}$ and $\left.24 \mathrm{~h}\right)$, environmental enhancement was nearly identical in NWC at $0.75 \mathrm{dpa}$. The cyclic cracking behavior seems to be unaffected by the degree of sensitization in irradiated Type 304 SS. This observation implies that thermal sensitization may not be the key factor for the IASCC process. With respect to the contribution of sensitization, irradiation effects may play a more important role in elevating SCC susceptibility in irradiated Type 304 SS.

Constant-load CGRs for the irradiated sensitized Type 304 SS are shown in Fig. 67. For both sensitization conditions (e.g. $10.5 \mathrm{~h}$ or $24 \mathrm{~h}$ at $600^{\circ} \mathrm{C}$ ), the constant-load CGRs with NWC at 0.75 dpa are less than two times higher than the NUREG-0313 curve. At this dose level, the constant-load CGRs for sensitized SS are much lower than those of the weld HAZ specimens (represented by the " $8 \times$ NUREG0313" line). The beneficial effect of HWC chemistry is again evident for the sensitized SS. A considerable reduction in CGR can be seen in HWC for Type $304 \mathrm{SS}$ sensitized for $24 \mathrm{~h}$. Meanwhile, the available data at 2 dpa do not show a significant increase in the growth rate. This finding may imply a weak dose dependence for constant-load CGR in sensitized Type 304 SS. The constant-load CGRs obtained at slightly different $\mathrm{K}$ levels are fairly consistent for the two sensitization conditions. This observation again confirms that the degree of sensitization does not play a significant role in promoting $\mathrm{SCC}$ in irradiated materials. The effects of neutron irradiation must be a dominant factor contributing to the IASCC susceptibility. 


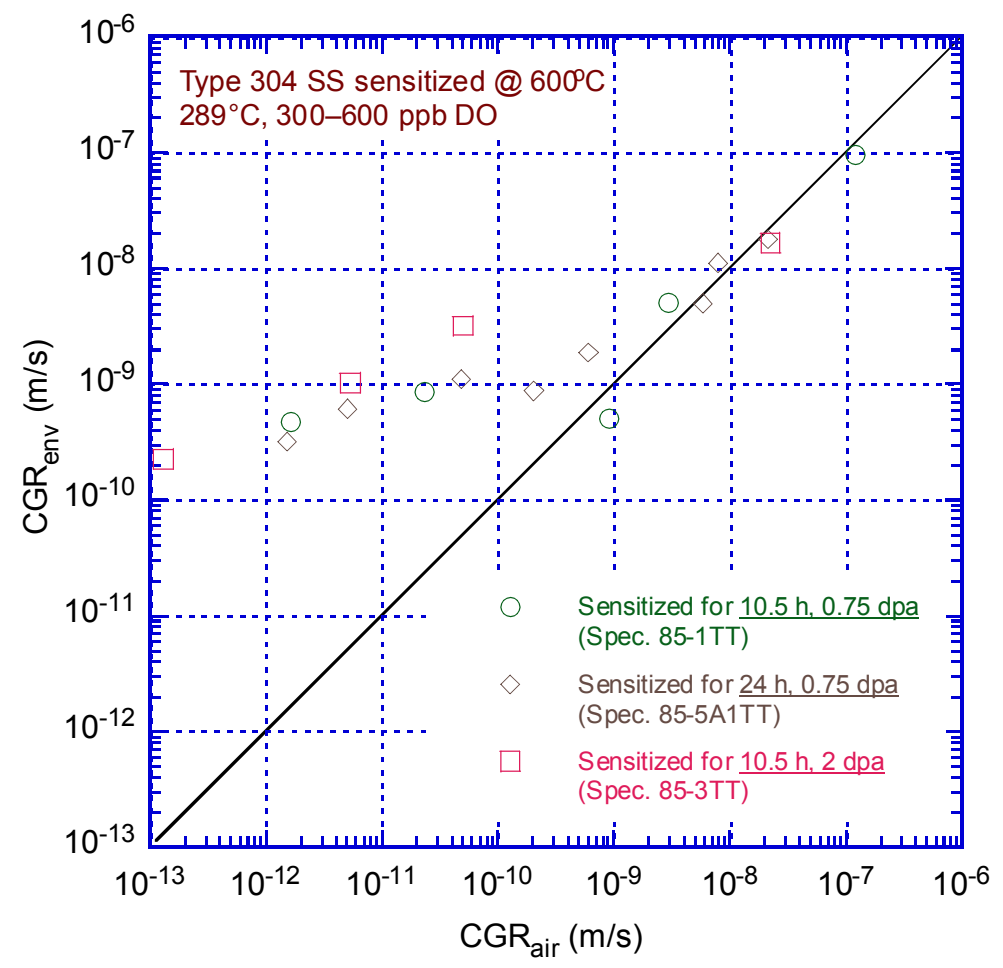

Figure 66. Cyclic CGRs for sensitized Type 304 SS irradiated to 0.75 and 2 dpa.

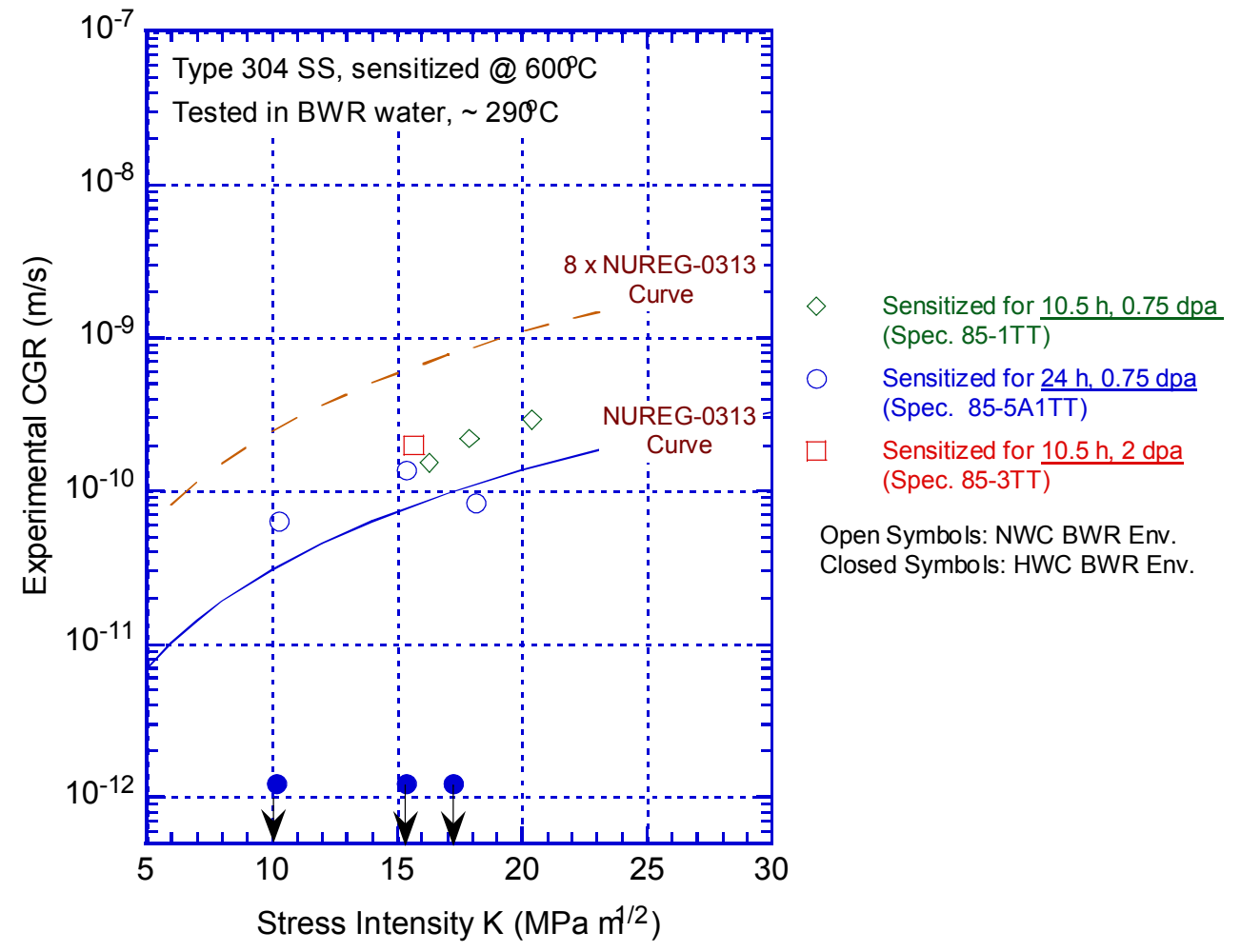

Figure 67. Constant-load CGRs versus stress intensity of sensitized Type 304 SS irradiated to 0.75 and 2 dpa. 
The fracture toughness of sensitized Type 304 SS is somewhat higher than that of the as-welded HAZ specimens. The $\mathrm{J}_{\mathrm{IC}}$ values of the specimens sensitized for $10.5 \mathrm{~h}$, irradiated to $0.75 \mathrm{dpa}$ (85-1TT) and $2 \mathrm{dpa}(85-3 \mathrm{TT})$ are $182 \mathrm{~kJ} / \mathrm{m}^{2}$ and $145 \mathrm{~kJ} / \mathrm{m}^{2}$ respectively. The 2-dpa specimen sensitized for $24 \mathrm{~h}$ $(85-5 \mathrm{~A} 2 \mathrm{TT})$ shows a slightly higher $\mathrm{J}_{\mathrm{IC}}$ value $\left(223 \mathrm{~kJ} / \mathrm{m}^{2}\right)$ when tested in air.

\subsection{Effect of Material Types}

The CGR/J-R test results from the Halden-I study are used to illustrate the influence of material type and material chemistry on IASCC behavior. Three austenitic SSs (Type 304L, 316, and 316L SSs) irradiated to three dose levels $(0.45,1.35$, and $3 \mathrm{dpa})$ are included in the discussion. Table 14 shows the composition of these alloys, and experimental details can be found in references [19], [20], and [68].

Table 14. Composition of austenitic stainless steels (wt\%)

\begin{tabular}{cccccccccccc}
\hline Steel Type & Heat ID & $\mathrm{Ni}$ & $\mathrm{Si}$ & $\mathrm{P}$ & $\mathrm{S}$ & $\mathrm{Mn}$ & $\mathrm{C}$ & $\mathrm{N}$ & $\mathrm{Cr}$ & $\mathrm{Mo}$ & $\mathrm{O}$ \\
\hline 304L & $\mathrm{C} 3$ & 9.10 & 0.45 & 0.020 & 0.003 & 1.86 & 0.024 & 0.074 & 18.93 & 0.12 & 0.014 \\
316L & $\mathrm{C} 16$ & 12.32 & 0.42 & 0.026 & 0.003 & 1.65 & 0.029 & 0.011 & 16.91 & 2.18 & 0.016 \\
316 & $\mathrm{C} 21$ & 10.45 & 0.61 & 0.035 & 0.002 & 1.23 & 0.060 & 0.016 & 16.27 & 2.10 & 0.014 \\
\hline
\end{tabular}

Figure 68 shows the cyclic CGR data at different dose levels for comparison. At 0.45 dpa (Fig. 68 a), no environmental enhancement was detected for Type 304L SS (specimen C3-A), while moderate enhancement was observed for Type 316 SS (specimen C21-A). All data points meet the $\mathrm{K} /$ size requirement in Eq. (3). With increasing dose, environmentally enhanced cracking became evident, and the difference in cyclic CGRs for different austenitic SSs was also diminished. At 1.35 and 3 dpa (Fig. 68 b and c), cyclic CGRs for Type 304L and 316 SSs were nearly identical. The low-carbon Type 316 SS (specimen C16-B) showed slightly lower cyclic CGRs than the normal-carbon-content Type 316 SS (specimen C21-C) at $3 \mathrm{dpa}$. Note that the nickel content in the Type 316L SS is also higher than that in the Type 316 SS. So, the slightly lower cyclic CGRs observed in Type 316L SS may be due to its high nickel content.

Constant-load CGRs of austenitic SSs at the three dose levels are plotted in Fig. 69 along with the NUREG-0313 and the 8-times-NUREG-0313 lines. At 0.45 dpa (Fig. 69a), two data points for Type 304L SS are invalid for the K/size criterion by Eq. (3). The remaining CGRs satisfy the K/size criterion. The CGRs at $0.45 \mathrm{dpa}$ in simulated BWR NWC are very close to the NUREG-0313 curve that was developed based on the CGR data for nonirradiated and sensitized SSs in high-DO water. The CGRs for Type 316 SS (specimen C21-A) are slightly higher than those of Type 304L SS (specimen C3-A). In general, IASCC susceptibility for both austenitic SSs at this dose level is comparable to or slightly higher than that of nonirradiated sensitized SSs.

With the increase of irradiation dose, IASCC susceptibility becomes evident at $1.35 \mathrm{dpa}$. Constantload CGRs are elevated considerably at this dose level as shown in Fig. 69b. The cracking behavior between Type 304L (specimen C3-B) and 316 SSs (specimen C21-B) is very similar, and the measured constant-load CGRs are between 5 and 10 times higher than the NUREG-0313 curve. The beneficial effect of HWC is clearly demonstrated, and constant-load CGRs in HWC are at least one order of magnitude lower than those in NWC. An additional increase in irradiation dose to 3 dpa did not elevate the CGRs further in NWC, as shown in Fig. 69c (open symbols). The constant-load CGRs in NWC are still scattered around the 8-times-NUREG-0313 curve. Type 316 SS (specimen C21-C) exhibits slightly higher CGRs than those of Type 304L (specimen C3-C) and 316L SSs (specimen C16-B). Compared to the 1.35-dpa data, the most noticeable change at 3 dpa is the CGRs in HWC (closed symbols in Fig. 69c). The beneficial effect of HWC becomes less pronounced, especially for the Type 304L and 316 SSs under high applied load. This observation will be discussed further in the following section. 


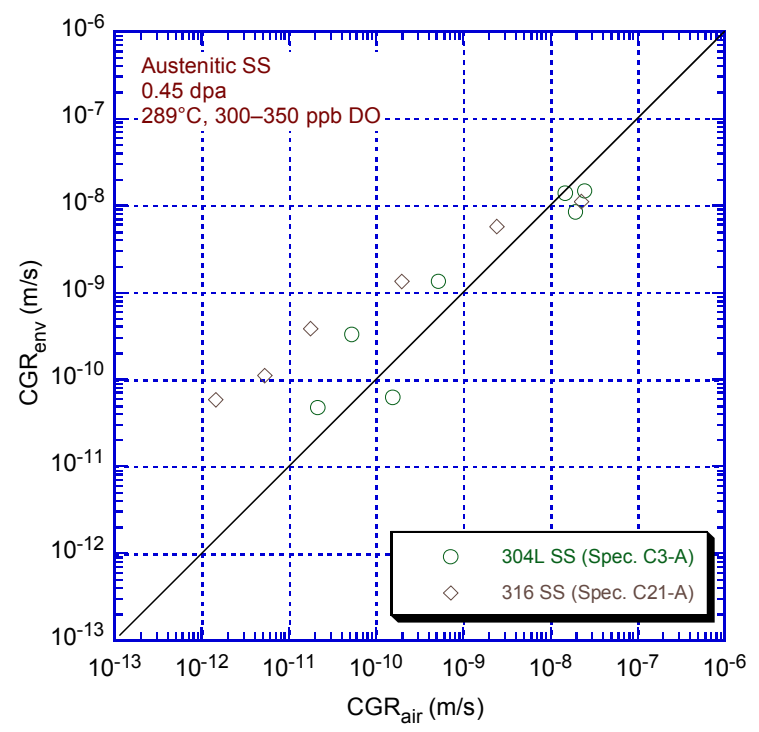

(a)

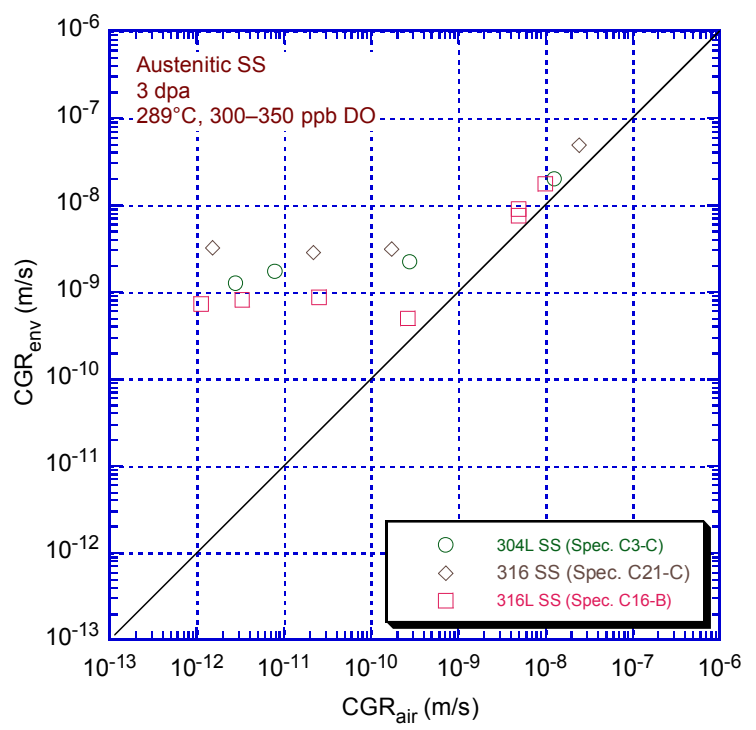

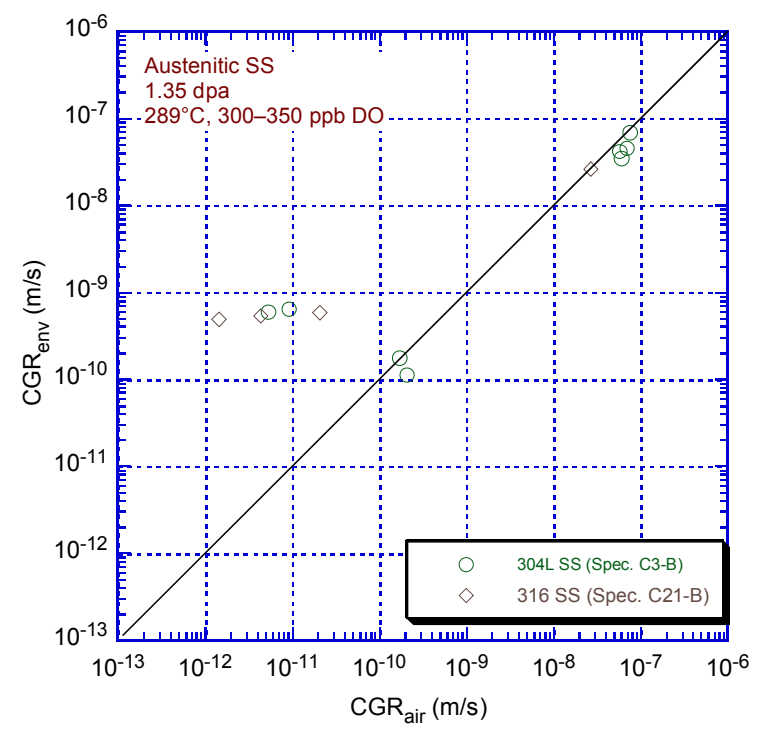

(b)

Figure 68. Cyclic CGRs for austenitic SSs irradiated to (a) $0.45 \mathrm{dpa}$, (b) $1.35 \mathrm{dpa}$, and (c) 3 dpa.

(c)

Additional information on the influence of materials chemistry on IASCC susceptibility was obtained from slow-strain-rate-tensile (SSRT) tests. ${ }^{24,69-72}$ In the Halden-I and -II studies, numerous SSRT tests were performed to screen a wide range of materials with different composition. A higher IASCC susceptibility was found for low-carbon and high-sulfur austenitic SSs. A sulfur content below $0.002 \mathrm{wt} . \%$ was found to be critical for IASCC resistance in austenitic SSs in high-DO BWR water. With a similar sulfur composition, a low-carbon austenitic SS is more susceptible to IASCC than normalcarbon SSs. A minimum carbon content is needed to suppress IASCC susceptibility in the low-sulfur steels. ${ }^{70}$ Thus, there may be a trade-off in minimizing susceptibility to IASCC and minimizing susceptibility to IG cracking resulting from conventional sensitization. Type $316 \mathrm{SSs}$ were found to be generally more resistant to IASCC than Type 304 SSs with the same sulfur and carbon composition. The presence of molybdenum or the higher nickel concentration in Type 316 SSs may be responsible for the 
difference in IASCC susceptibility between Type 304 and 316 SSs. ${ }^{74,75}$ The oxygen content is also critical for IASCC susceptibility because high oxygen content may increase the possibility of IG crack initiation. 76

Elevated cracking susceptibility has been reported in nonirradiated austenitic SSs with high silicon content. ${ }^{77,78}$ The high CGRs observed in these high-silicon alloys were also insensitive to corrosion potential. ${ }^{77}$ This observation suggests that radiation-induced segregation (RIS) of silicon to grain boundaries could also have a profound effect on IASCC susceptibility. It is well known that silicon concentration at the grain boundaries can be elevated significantly under neutron irradiation. At about 3 dpa, silicon concentration as high as $4-5 \mathrm{wt} . \%$ has been detected at grain boundaries in SSs. ${ }^{79}$ With this level of silicon concentration, cracking resistance could be affected. However, despite the possible detrimental effect imposed by the RIS of silicon, the influence of silicon on IASCC susceptibility remains to be verified in irradiated SSs.

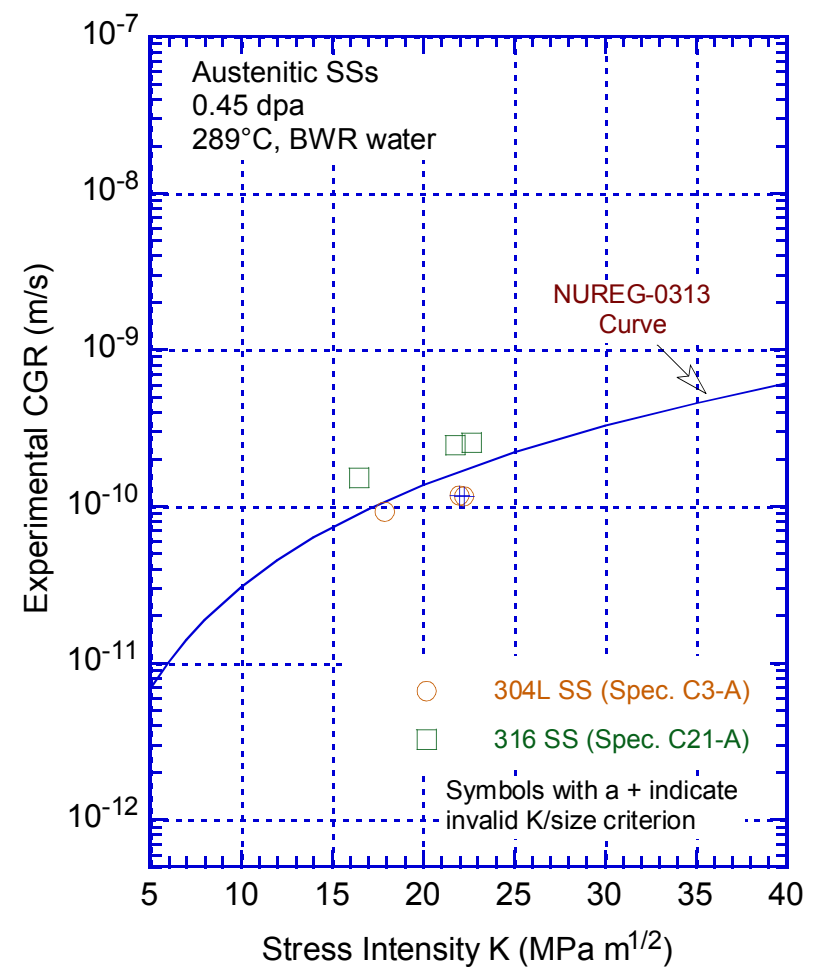

(a)

Figure 69. Constant-load CGRs versus stress intensity for austenitic SSs irradiated to (a) $0.45 \mathrm{dpa}$, (b) $1.35 \mathrm{dpa}$, and (c) 3 dpa. 


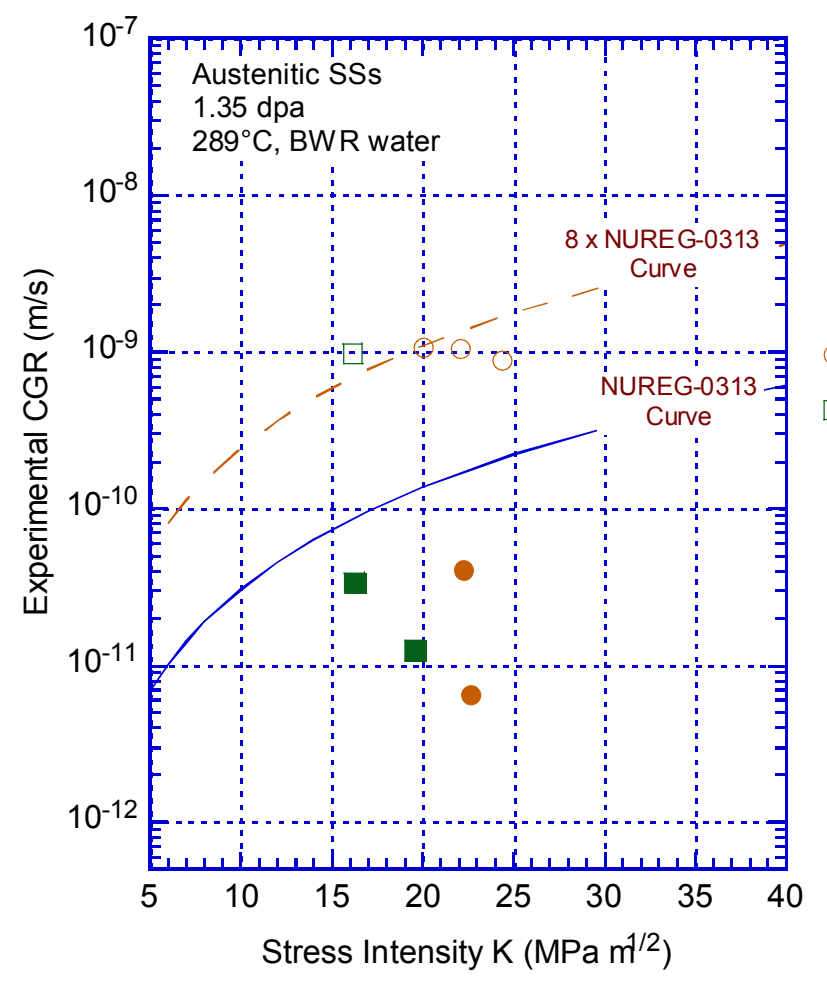

\section{L SS (Spec. C3-B) \\ $\square \quad 316$ SS (Spec. C21-B)}

Open Symbols: NWC BWR Env. Closed Symbols: HWC BWR Env.

(b)

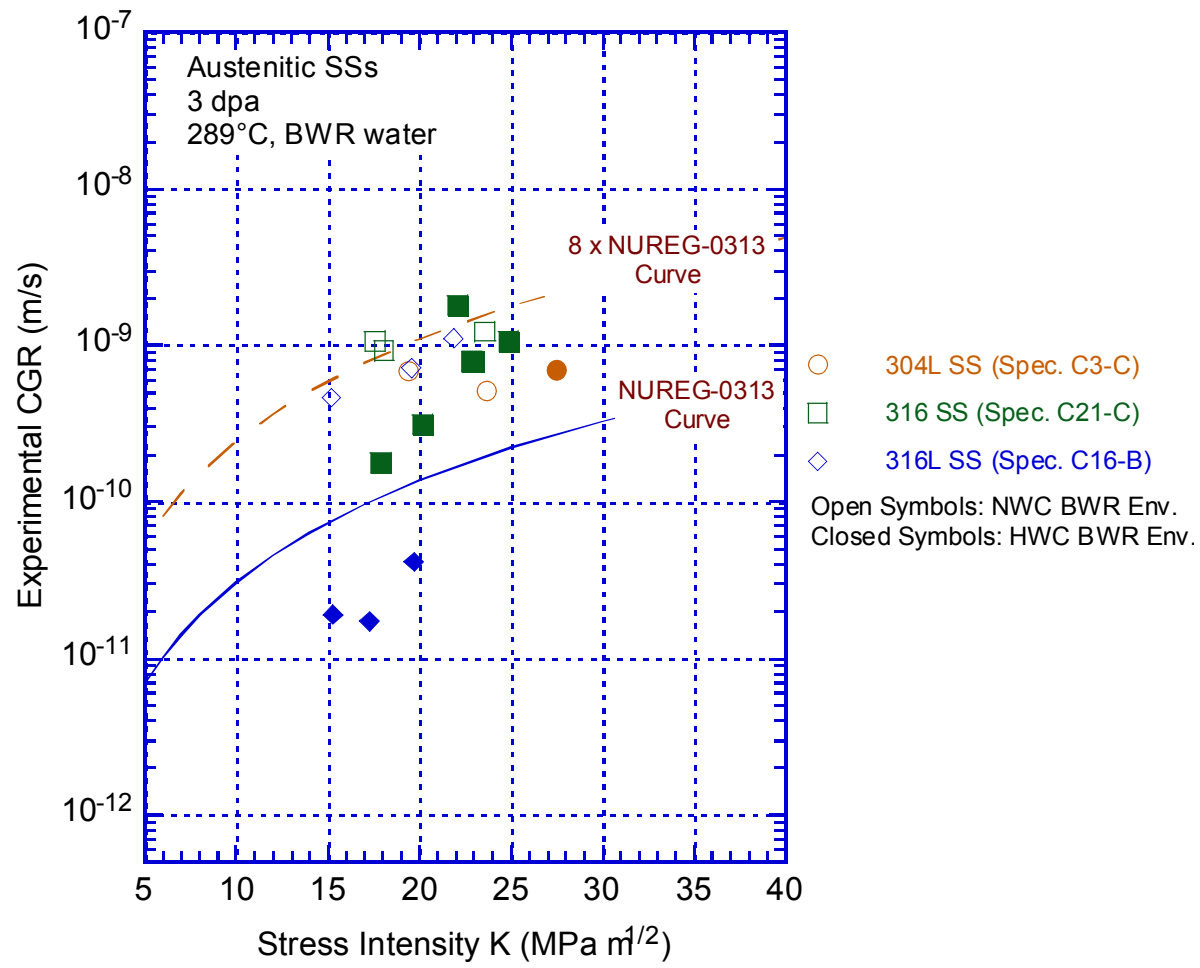

(c)

Figure 69. (Contd.) 


\subsection{Effect of Water Chemistry}

It is accepted that SCC susceptibility is a strong function of corrosion potential. A low corrosionpotential system is believed to suppress the crack-tip dissolution rate and thus reduce the rate of crack growth substantially. ${ }^{29,80,81}$ In the above sections, we have demonstrated repeatedly that HWC can effectively reduce the severity of cracking in the BWR water environment. In this section, the CGR results from the Halden-I and -II studies concerning HWC will be presented again in a collective way to further illustrate the effect of water chemistry.

Figure 70 shows two cyclic CGR tests performed on Type 304L and 316L SSs in NWC and HWC. The Type 304L SS was irradiated to $1.35 \mathrm{dpa}$, and the Type 316L SS was irradiated to $3 \mathrm{dpa}$. Both materials exhibit a significant amount of environmental enhancement under cyclic loading in NWC (open symbols in Fig. 70). When the same materials were tested under cyclic loading in HWC, much weaker environmental enhancement was observed. The CGR data for NWC and HWC are best represented by the Shack/Kassner model ${ }^{48}$ :

$$
\mathrm{CGR}_{\mathrm{env}}=\mathrm{CGR}_{\mathrm{air}}+\alpha \cdot \mathrm{CGR}_{\mathrm{air}} \mathrm{m} \text {, }
$$

where the coefficient $\alpha$ and the exponent $m$ are derived by fitting of the experimental data. As shown by Fig. 70, the CGR in HWC is more than one order of magnitude lower than that in NWC under a similar cyclic loading condition.

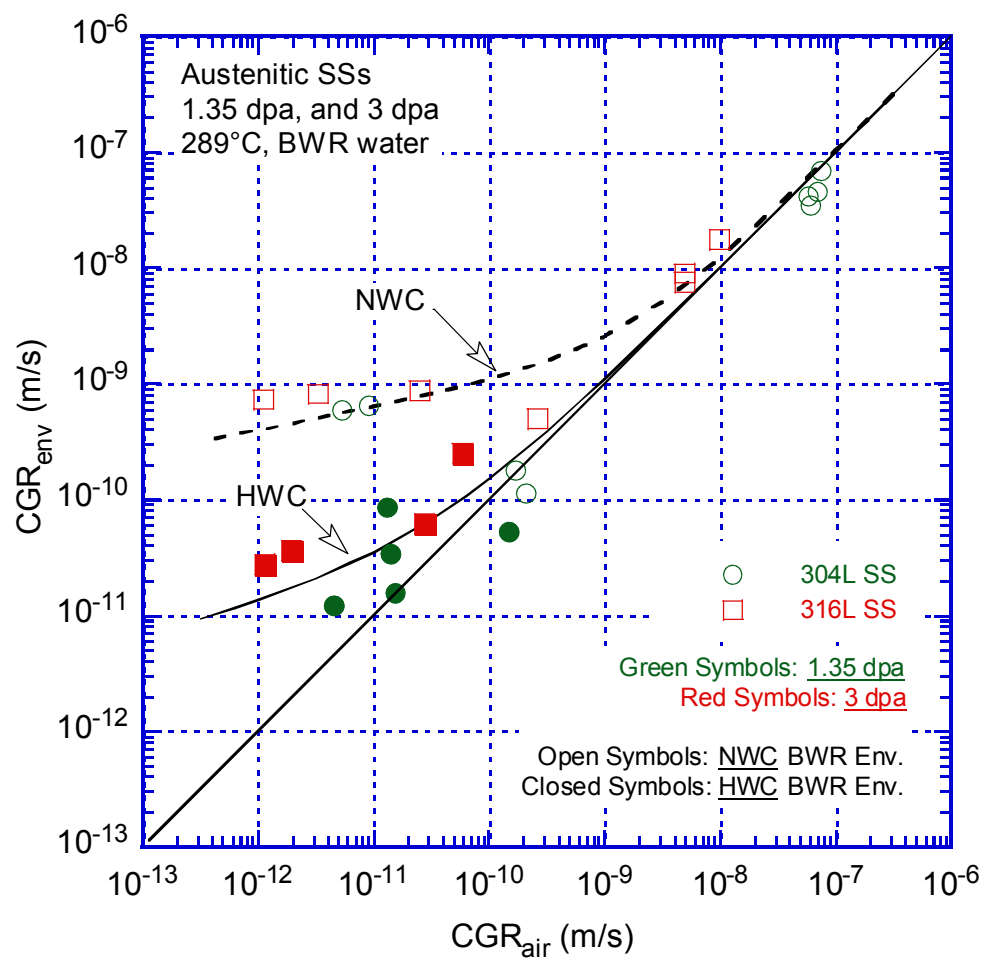

Figure 70. Cyclic CGRs for Type $304 \mathrm{~L}$ and $316 \mathrm{~L}$ SSs in NWC and HWC tests.

All constant-load CGR data in the Halden-I and -II studies concerning the water chemistry effect are presented in three groups in Fig.71: sensitized and non-sensitized SSs and weld HAZ. Data for NWC and HWC are indicated by open and closed symbols, respectively. The NUREG-0313 curve is included as a reference. Despite large scatter of the data, the CGRs for NWC (open symbols) and HWC (closed symbols) separate into two groups. The CGRs are much higher in NWC than in HWC for all materials 
and most irradiation doses included in the present study. The only exception is the data points for the 3 dpa specimens tested in the high-K range.

Relatively high CGRs under HWC were also reported by other authors for high-dose specimens at high applied load. $60,82,83$ This abnormal cracking behavior in HWC was discussed in the context of $\mathrm{K} /$ size criterion. It has been argued that loss of constraint under a high applied load may compromise the test results. ${ }^{59}$ However, no compelling explanation has been given to correlate the constraint condition with the growth rate. Nonetheless, the diminishing HWC beneficial effect in high-dose specimens under high applied load may be more complex than simple mechanics (loss of constraint) can explain. A comprehensive investigation on the possible interactions between the crack tip plasticity and local water chemistry may be required to fully understand this phenomenon.

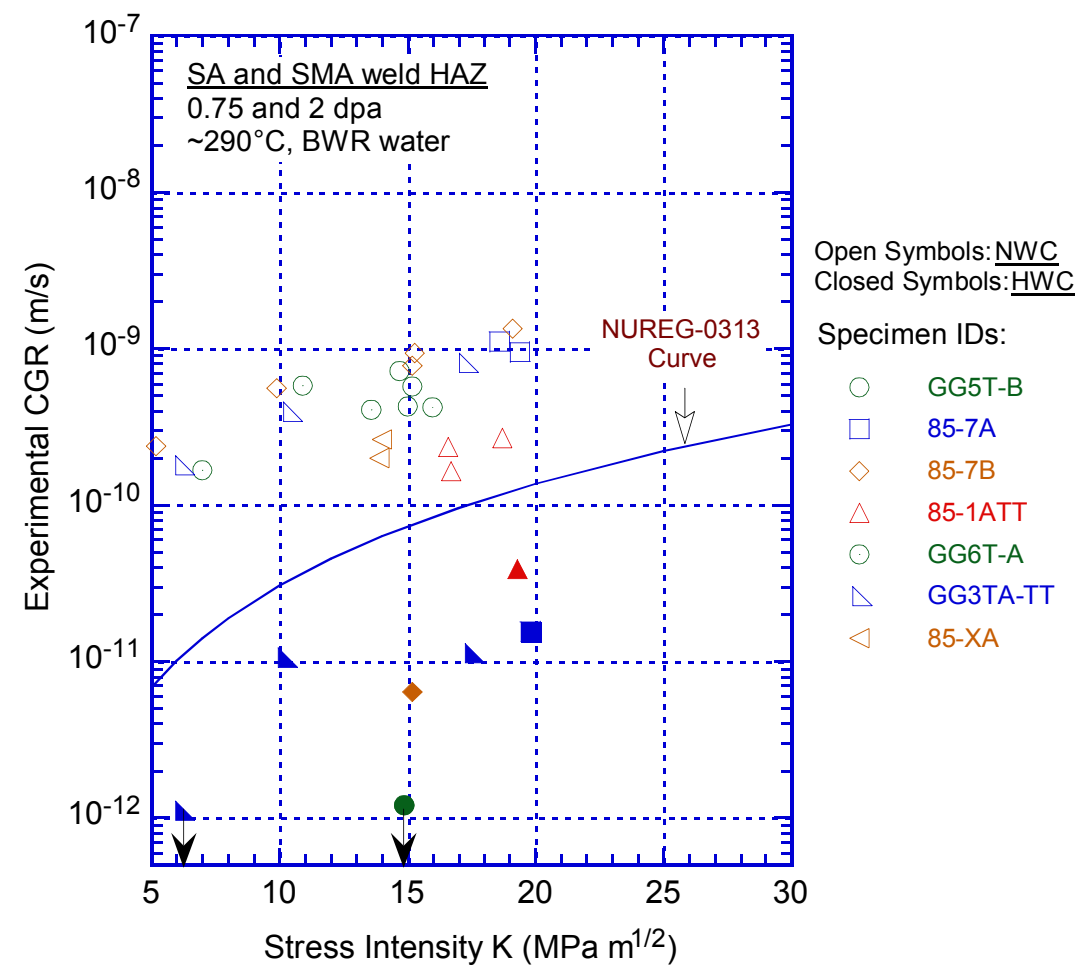

(a)

Figure 71. Constant-load CGRs versus stress intensity in NWC and HWC for (a) weld HAZ, (b) sensitized 304 SS, and (c) wrought SSs. 


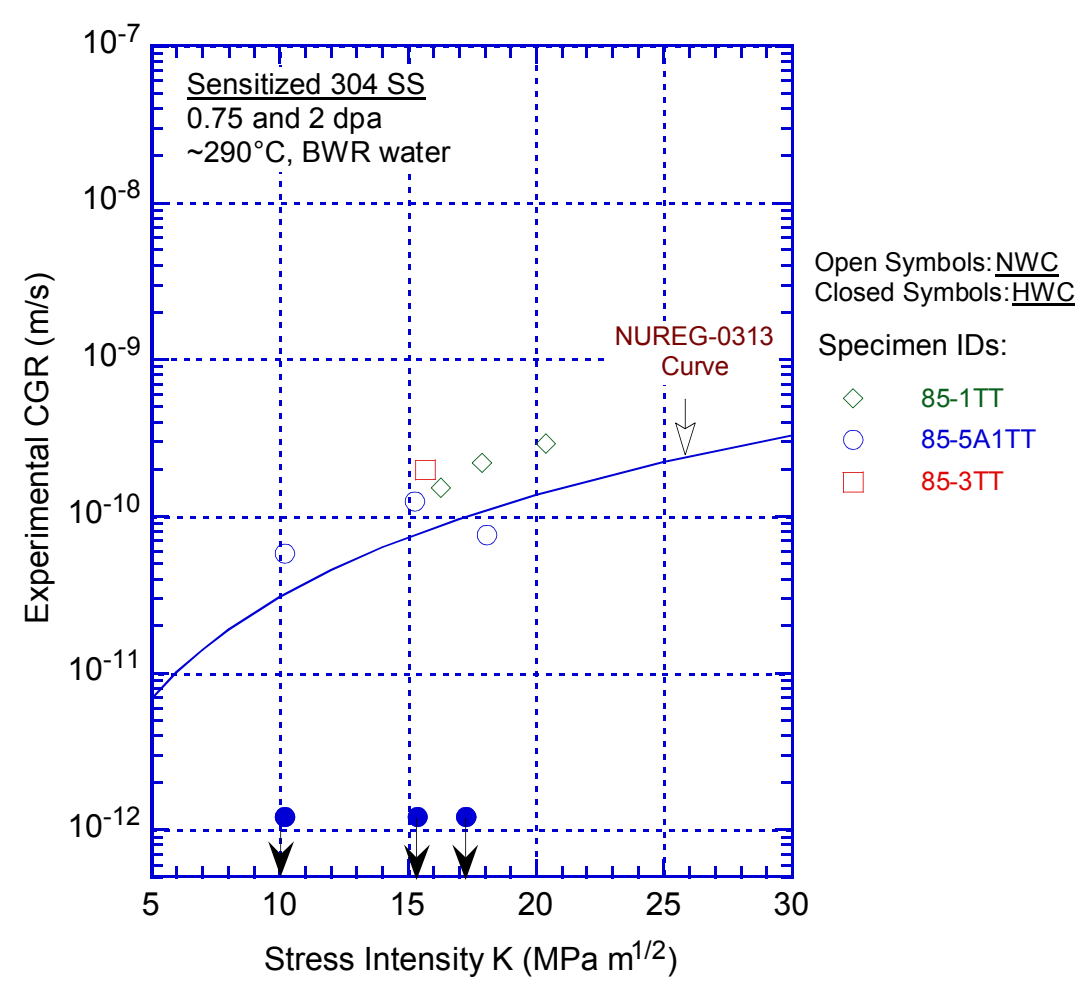

(b)

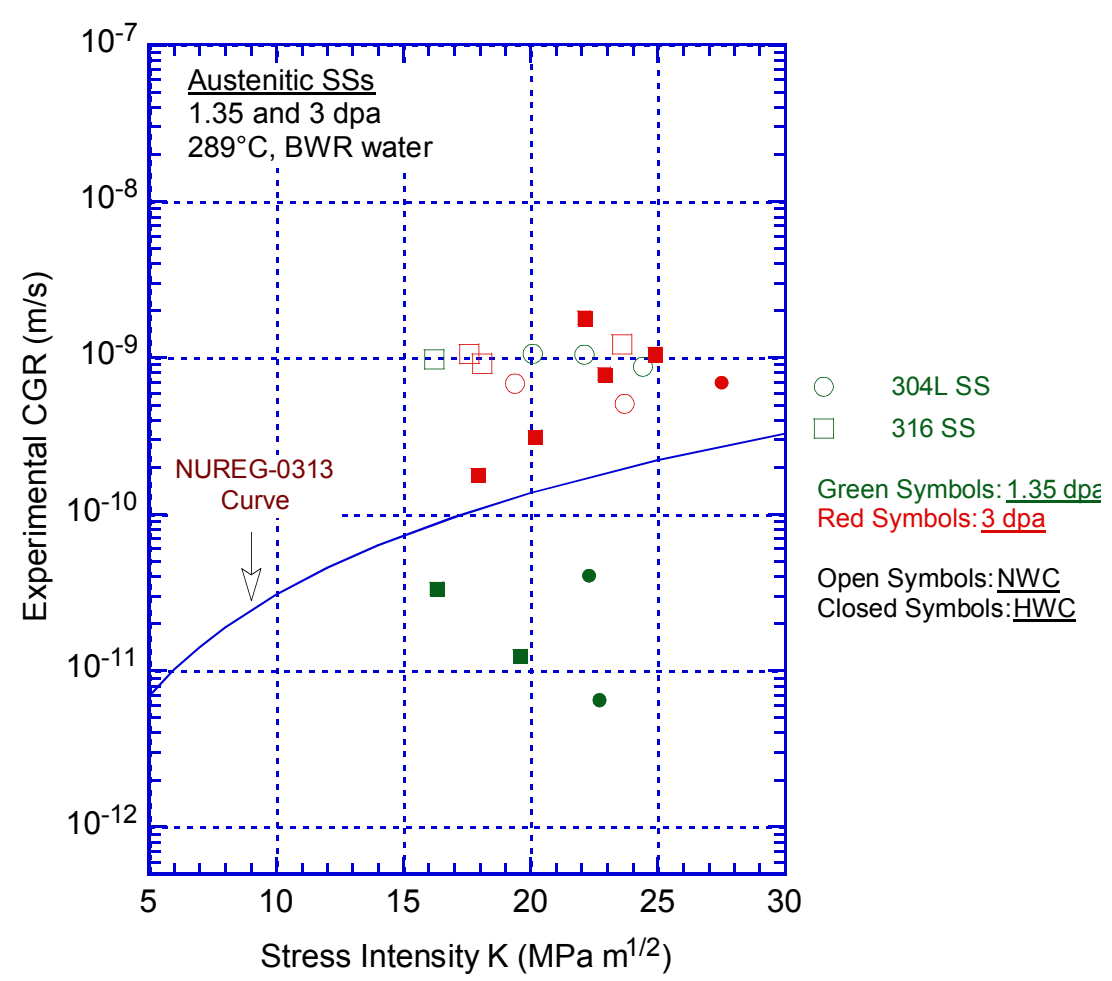

Figure 71. (Contd.)

(c) 


\subsection{Effect of Neutron Dose}

Previous Halden reports 70,71 have addressed the influence of neutron dose on IASCC in SSRT tests. They contend that IASCC susceptibility is affected by irradiation hardening, embrittlement, and radiation-induced microstructural and microchemistry changes. All these irradiation effects are dosedependent, and therefore, IASCC behavior must vary with neutron dose as well. The SSRT tests indicated that the percentage of IG cracking on the fracture surface is minimal below 0.45 dpa in high-DO water. With an increase of dose beyond $1.35 \mathrm{dpa}$, the fraction of IG cracking increases rapidly for the fracture surface. ${ }^{71,72}$ At $\approx 3 \mathrm{dpa}$, some austenitic SSs exhibit nearly $100 \%$ IG fracture, while others still retain fairly ductile fracture morphology. This observation indicates that the effect of dose on IASCC behavior is different from one material to another.

Since IASCC is a complex function of material and environmental variables, it is not easy to single out the dose effect from the CGR test results. To minimize the influence of other factors, the Halden-I CGR results in NWC on Type 304L, 316 and 316L SSs at 0.45, 1.35 and 3 dpa are used for the analysis. The mechanical properties of these specimens are similar for each of the three dose levels. Figure 72 shows the cyclic CGRs of these austenitic SSs. With increasing dose from 0.45 to $3 \mathrm{dpa}$, cyclic CGRs in the test environment start to deviate from the diagonal line at an increasingly higher growth rate. The rising environmental enhancement under the cyclic loading condition indicates an increased IASCC susceptibility.

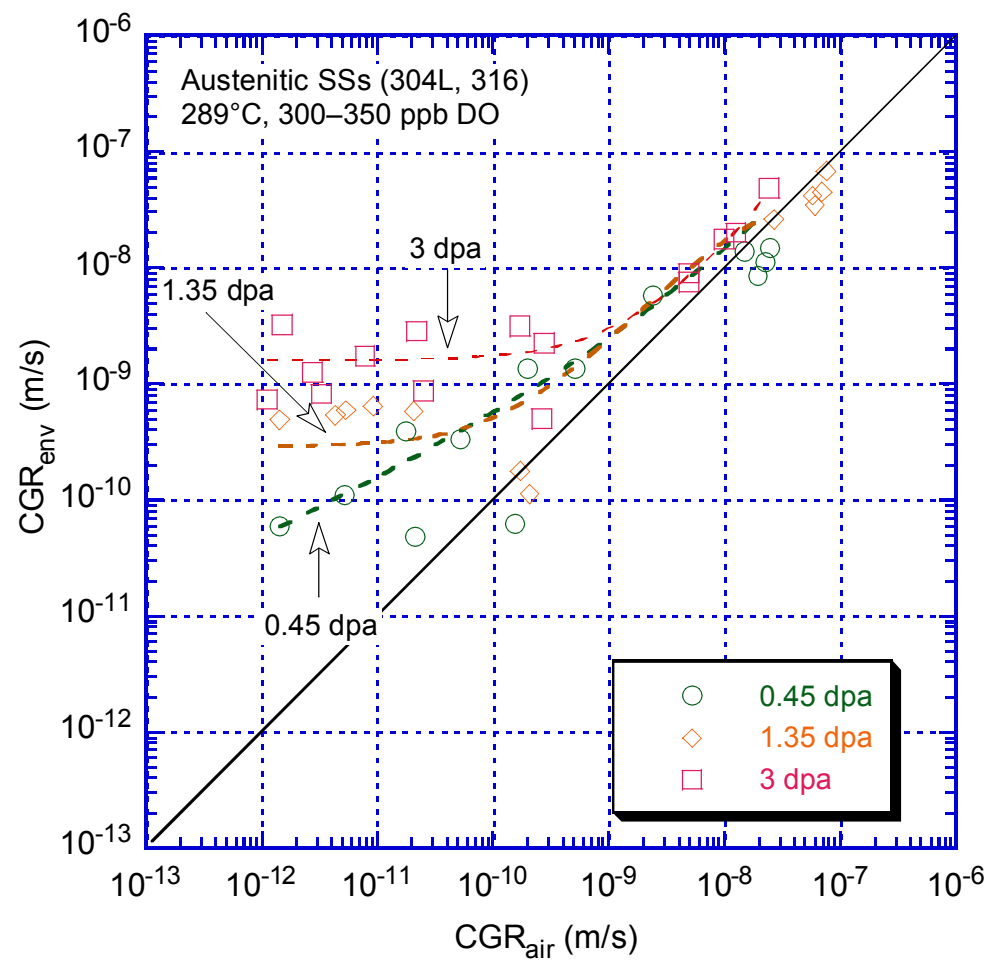

Figure 72. Dose dependence of cyclic CGRs for Type 304L and 316 SSs.

The constant-load CGRs are plotted in Fig. 73 for the same group of specimens in NWC. The data points at the same dose level are fitted with the power law in Eq. (10). The coefficient A is determined to be $2.3 \times 10^{-13}, 1.25 \times 10^{-12}$, and $1.15 \times 10^{-12} \mathrm{~m} / \mathrm{s}$ for $0.45,1.35$, and $3 \mathrm{dpa}$, respectively. An increasing trend 
can be seen for the constant-load CGR between 0.45 and $1.35 \mathrm{dpa}$, but no change is evident between 1.35 and 3 dpa for CGR. This trend may imply a saturation effect of constant-load CGR in the high dose region.

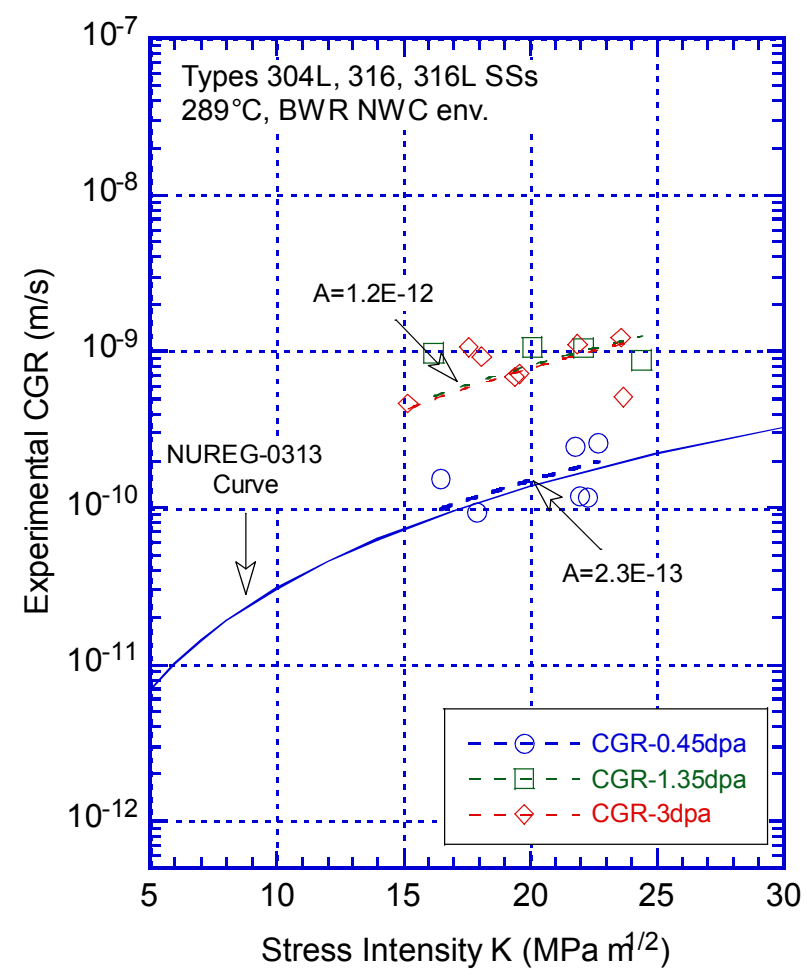

Figure 73. Constant-load CGRs versus stress intensity for Type 304L, 316 and 316L SSs at different doses.

The effect of neutron irradiation on fracture toughness has been discussed in detail in a previous Halden report. ${ }^{20}$ Irradiation embrittlement is mainly responsible for the reduction in fracture toughness in irradiated materials. The results of BWR irradiated materials fall within the scatter band but are close to the lower bound of the data obtained from fast reactor irradiations. The fracture toughness of various austenitic SSs decreases rapidly with irradiation dose from nonirradiated values of $400-600 \mathrm{~kJ} / \mathrm{m}^{2}$ to less than $100 \mathrm{~kJ} / \mathrm{m}^{2}$. At $3-5 \mathrm{dpa}$, the $\mathrm{J}_{\mathrm{IC}}$ of some austenitic $\mathrm{SS}$ can be as low as $15 \mathrm{~kJ} / \mathrm{m}^{2}$. Limited data showed little environmental effect on the measured fracture toughness in BWR water. The J-R tests conducted in air and in water environment yielded approximately the same results. Figure 74 summarizes the fracture toughness data obtained in the Halden study. These data are also compared with data from similar studies. In the previous Halden study, the threshold neutron dose for a sharp decrease in fracture toughness was found to be about $0.3 \mathrm{dpa}$ for austenitic SSs. Above $5 \mathrm{dpa}$, little plasticity is anticipated in austenitic SSs prior to fracture. 


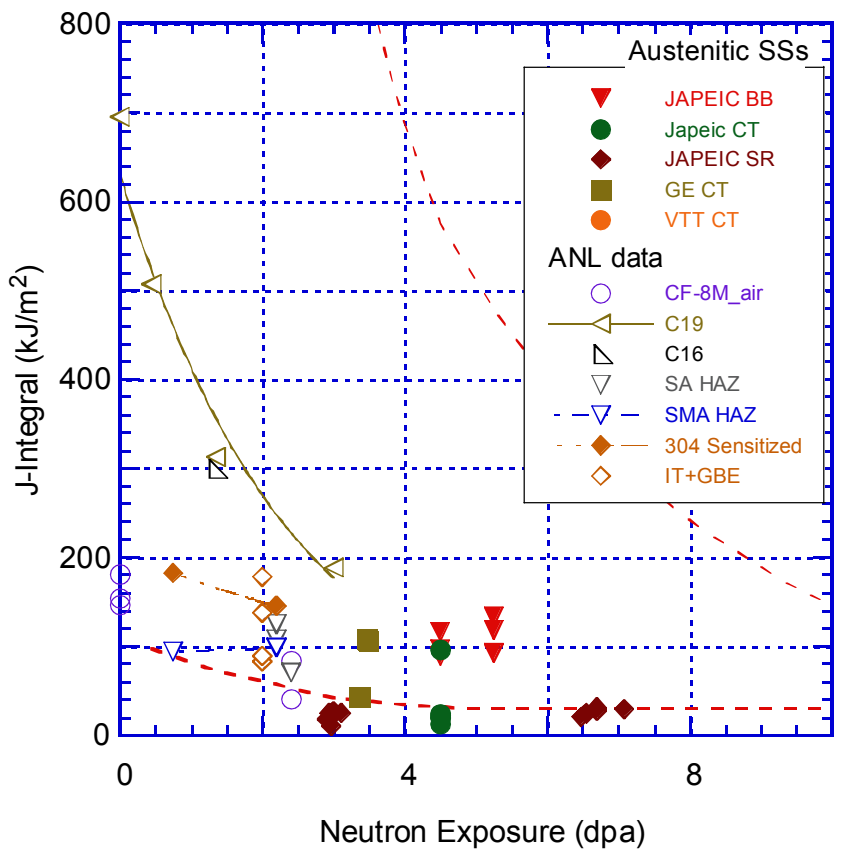

Figure 74. Dose dependence of fracture toughness for austenitic SSs. Dashed lines represent the scatter band for the fast reactor data at $350-450^{\circ} \mathrm{C} .20$

$(\mathrm{GE}=$ General Electric Nuclear Energy, JAPEIC = Japan Power Engineering and Inspection Corporation, $\mathrm{CT}=$ compaction tension, $\mathrm{BB}=$ bend bar, and $\mathrm{SR}=$ short rod.)

\subsection{Effect of GBE Treatment}

\subsubsection{Crack Growth Rates for GBE and Non-GBE Type 304 and 316 SSs}

Grain boundary engineering (GBE) is a thermomechanical processing technique that systematically increases the population of low $\Sigma$ coincident site lattice $(\mathrm{CSL})^{*}$ grain boundaries in materials. ${ }^{73}$ Because the low $\Sigma(\leq 29)$ grain boundaries usually exhibit good resistant to IG cracking in nonirradiated materials, ${ }^{37-40} \mathrm{GBE}$ has also been considered to be a potential mitigation method for IASCC. Type 304 and 316 SSs with and without GBE were included in the present study to investigate the effect of GBE treatment on IASCC susceptibility under conditions relevant to BWRs. Fractions for CSL boundaries are given in Table 2 for the non-GBE (baseline) and GBE Type 304 and 316 SSs.

Figure 75 shows the cyclic CGR results for non-GBE and GBE Type 304 and 316 SSs tested in NWC. All specimens were irradiated to 2 dpa prior to the CGR tests. The open and closed symbols represent the non-GBE and GBE materials, respectively, for all figures shown in this section. At 2 dpa, environmentally enhanced cracking was quite evident for Type 304 SSs with or without GBE treatment. The GBE Type 304 SS showed somewhat higher susceptibility to environmental cracking than the nonGBE Type 304 SS under cyclic loading. For Type 316 SSs, environmental enhancement was less pronounced compared to Type 304 SSs under a similar test condition. The GBE Type 316 SS showed some degree of environmental enhancement, while the non-GBE Type 316 SS displayed essentially no environmental effect under cyclic loading. In general, the cyclic CGRs indicate that the present GBE treatment did not improve IASCC behavior. In contrast, IASCC susceptibility may have been elevated, and higher cracking growth rates can be seen for GBE Type 304 and 316 SSs.

\footnotetext{
* An approach to describe atomic coherency of grain boundaries. A CSL grain boundary is defined by $\Sigma$, the reciprocal of the density of coincident sites.
} 


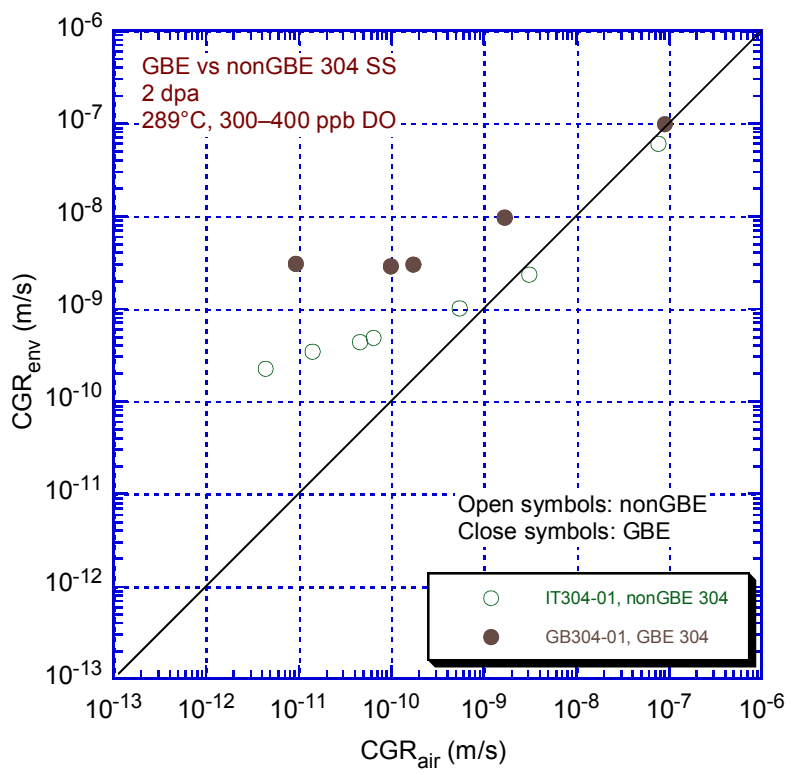

(a)

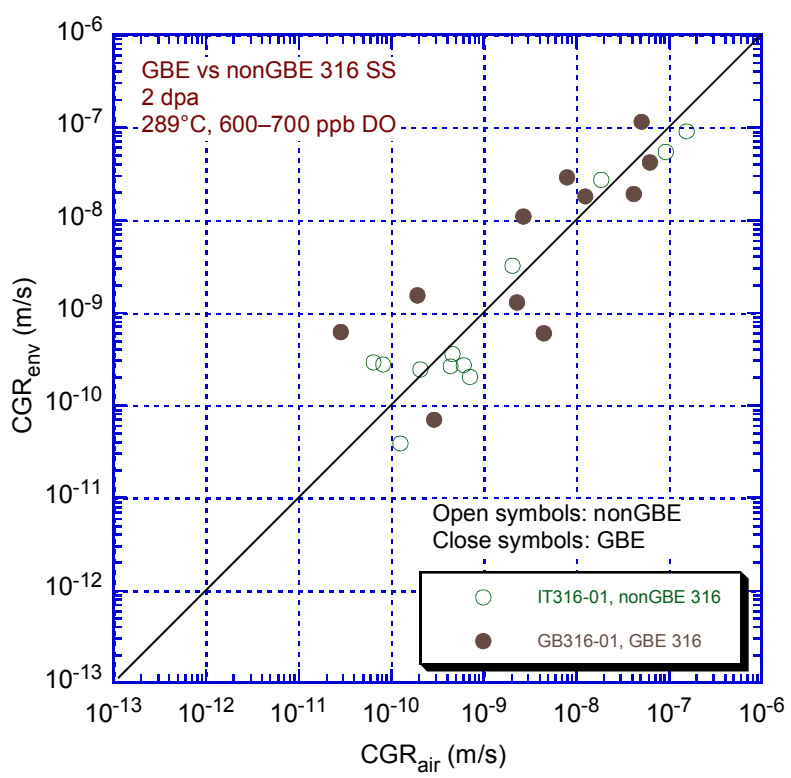

(b)

Figure 75. Cyclic CGRs for irradiated non-GBE and GBE treated (a) Type 304 SSs and (b) Type 316 SSs tested in BWR NWC.

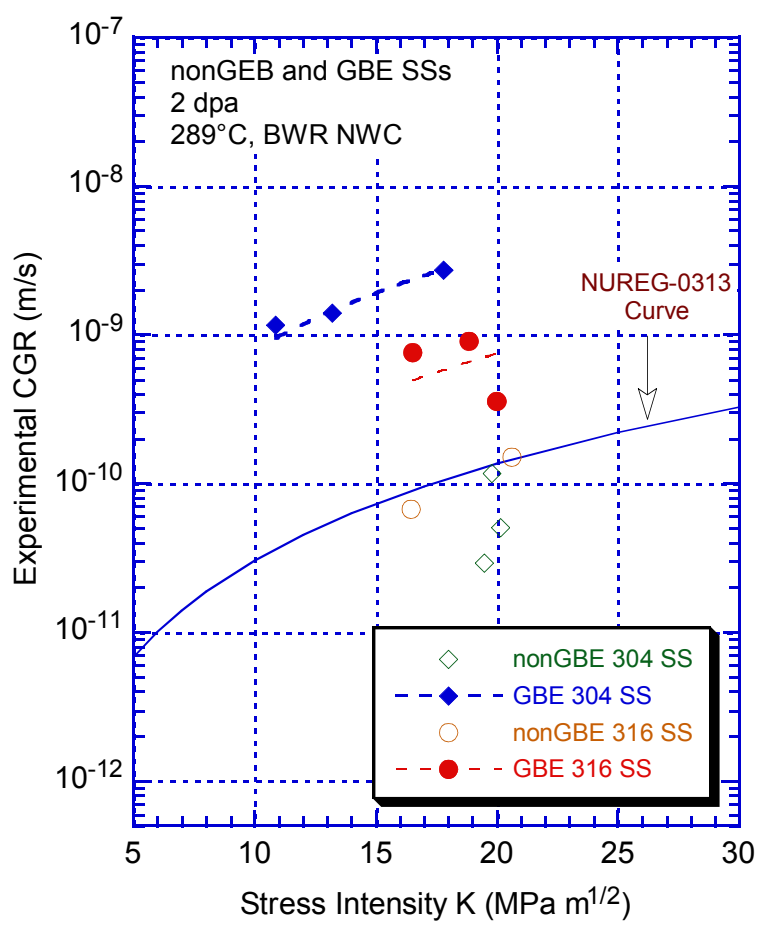

Figure 76. Constant-load CGRs versus stress intensity for non-GBE and GBE treated Type 304 and 316 SSs.

The constant-load CGRs for all non-GBE and GBE materials are shown in Fig. 76. The CGRs for both baseline materials (Type 304 and 316 SSs) are very close to or below the NUREG-0313 curve, which represents the CGR values for nonirradiated, sensitized austenitic SSs. However, the GBE-treated materials show considerably higher CGRs under the same test condition. The high constant-load CGRs for GBE materials verified the unfavorable outcome from the present GBE treatment. Both cyclic and 
constant-load CGR tests demonstrated that the GBE treatment employed in the present study did not improve the cracking resistance of the baseline materials. The GBE-treated Type 304 and 316 SS specimens exhibit a significantly higher susceptibility to IASCC.

\subsubsection{Fracture Toughness of GBE and Non-GBE Type 304 and 316 SSs}

Fracture toughness J-R tests were conducted on all non-GBE and GBE specimens after the CGR tests. The fracture toughness data for these alloys are shown in Fig. 77. Both baseline materials show relatively poor fracture toughness at $2 \mathrm{dpa}$. The $\mathrm{J}_{\mathrm{IC}}$ values are 83 and $89 \mathrm{~kJ} / \mathrm{m}^{2}$ for non-GBE Type 304 and $316 \mathrm{SSs}$, respectively. The fracture toughness of the two GBE materials is higher than that of the non-GBE materials. Apparently, the applied GBE treatment improves the irradiated fracture toughness for the baseline alloys. The different impact of GBE treatment on the CGR and fracture toughness results may indicate that fracture modes are different in the CGR and fracture toughness tests for these materials.

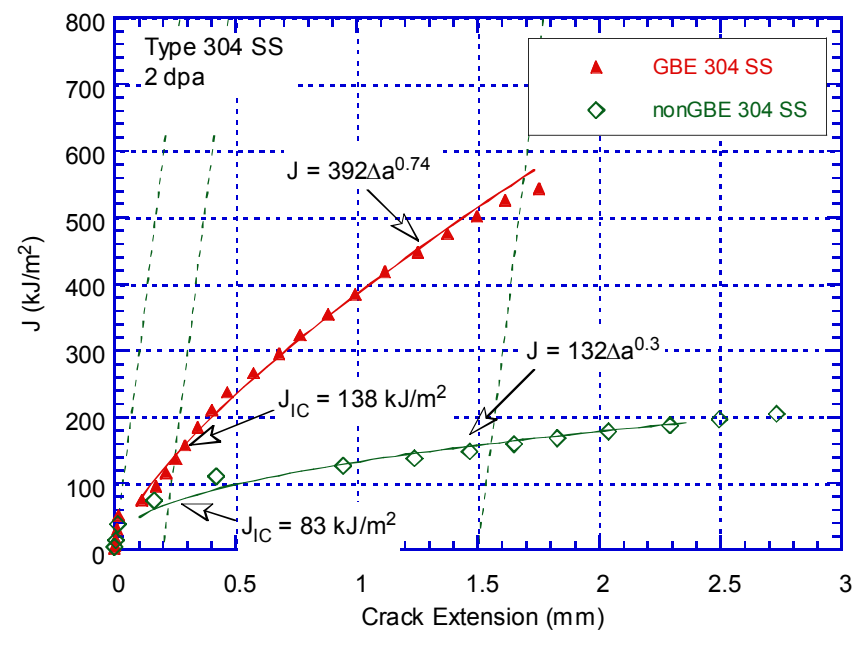

(a)

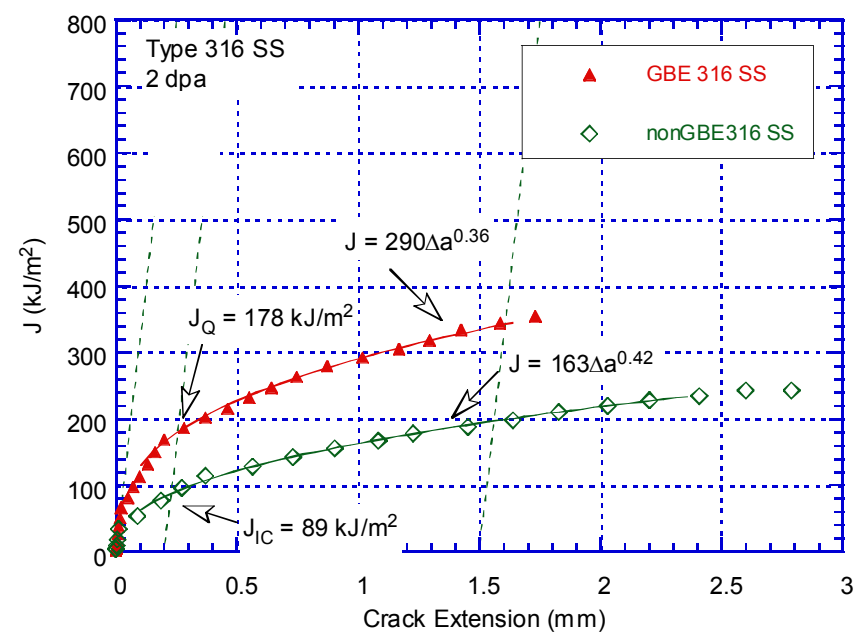

(b)

Figure 77. Fracture toughness J-R curves for non-GBE and GBE (a) Type 304 SSs and (b) Type 316 SSs.

\subsubsection{Hardness and Microstructure of Nonirradiated GBE and Non-GBE Type 304 and 316 SSs}

Hardness and microstructure of nonirradiated GBE and non-GBE Type 304 and 316 SSs were examined. Figure 78 shows the hardness measurement performed on the baseline and GBE materials prior to irradiation. The applied GBE treatment produced inconsistent results for the two types of austenitic SSs. For Type $316 \mathrm{SS}$, the GBE-treated material was harder than its baseline material. For Type 304 SS, the GBE-treated material was softer. 


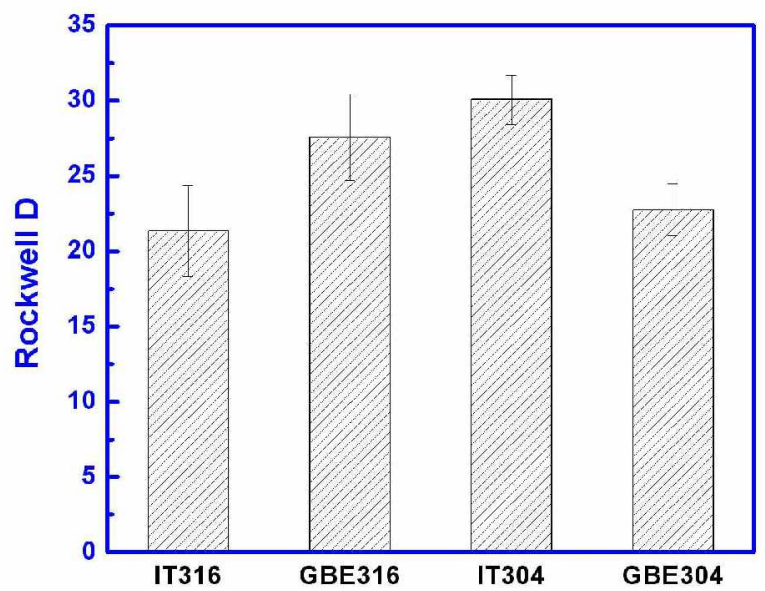

Figure 78. Hardness measurements of nonGBE and GBE Type 304 and 316 SSs.

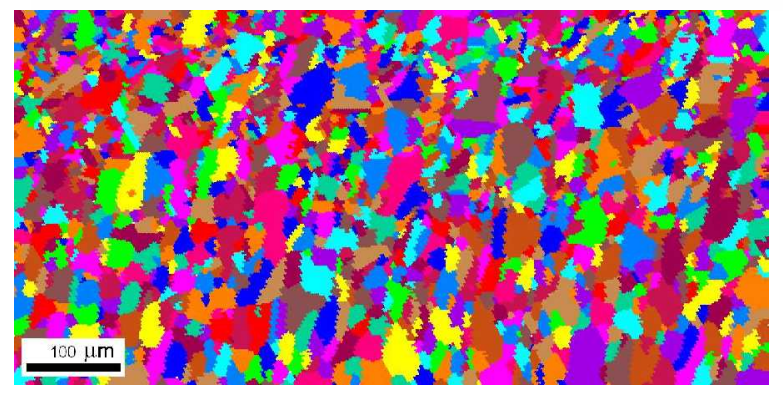

(a) non-GBE Type $304 \mathrm{SS}$

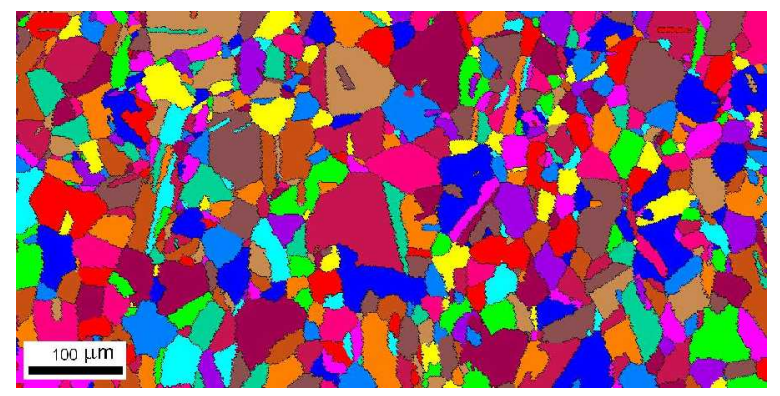

(c) non-GBE Type $316 \mathrm{SS}$

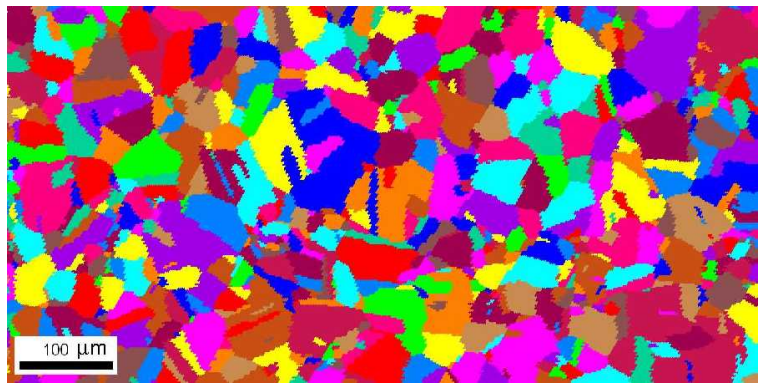

(b) GBE Type 304 SS

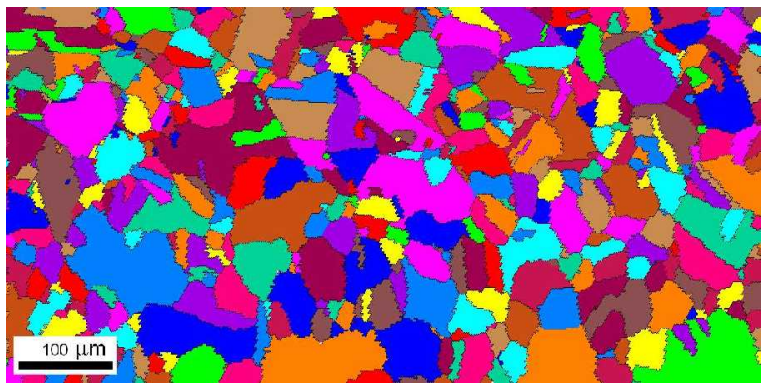

(d) GBE Type $316 \mathrm{SS}$

Figure 79. Grain morphology revealed by electron backscattered diffraction.

All four alloys were examined by electron backscattered diffraction to reveal their grain boundary configurations. Figure 79 shows the grain morphology for each alloy with and without GBE treatment. The quantitative measurements of grain structure are given in Fig. 80. The average grain size for GBE Type 304 SS (ASTM grain size number, G 6.5) is much larger than that of its baseline material (ASTM G 8.0). This increase in grain size by GBE processing may be responsible for the low hardness of GBE Type 304 SS shown in Fig. 78. For Type $316 \mathrm{SS}$, the grain size change due to GBE processing is minimal. The ASTM grain size numbers for GBE and non-GBE $316 \mathrm{SSs}$ are 6.0 and 6.5 respectively. The CSL fraction is quantified for each alloy according to the Brandon criterion, and the results are given in Fig. 80. The increase in CSL fraction is moderate for Type 304 SS, and much less for Type 316 SS. The population for low- $\Sigma$ boundaries is $67 \%$ for GBE Type 304 SS and about $58 \%$ for GBE Type 316 SS.

Transmission electron microscopy (TEM) images are shown in Fig. 81 for GBE and non-GBE Type 316 SS. While the non-GBE Type 316 SS is clean and free from precipitates, the GBE Type 316 
SS shows many precipitates scattered along grain boundaries and inside grains. The size of the precipitates is around $100-200 \mathrm{~nm}$. The precipitates were determined to be $\mathrm{M}_{6} \mathrm{C}$ ( $\eta$-carbide), $\mathrm{M}_{23} \mathrm{C}_{6}$, or $\mathrm{M}_{7} \mathrm{C}$. The increasing amount of precipitates found in the GBE-treated $316 \mathrm{SS}$ may be responsible for the elevated IASCC susceptibility after irradiation.

The TEM examination of GBE and non-GBE 304 SSs revealed a larger grain size but fewer precipitates in the GBE material (as shown in Fig. 82). Stress concentration resulting from dislocation pile-ups could be seen at grain boundaries. Non-uniform dislocation networks were also observed in some areas in the GBE 304 SS. The larger grain size exhibited in the GBE material may be the primary reason for the high cracking rate demonstrated in the CGR test.

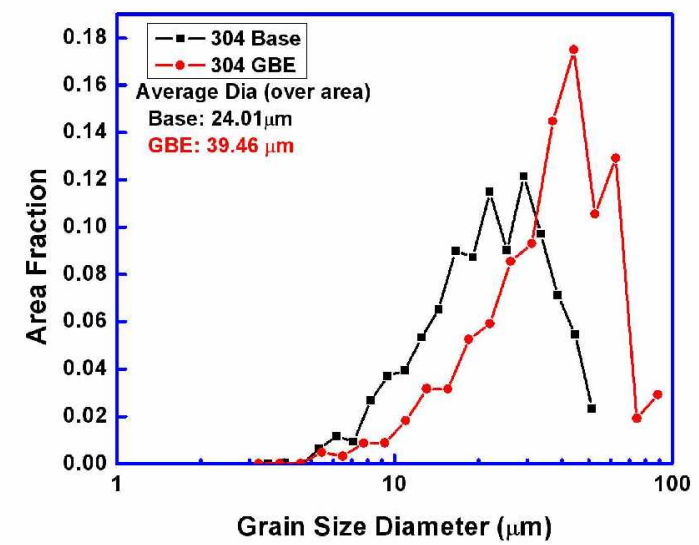

$304 \mathrm{SS}$

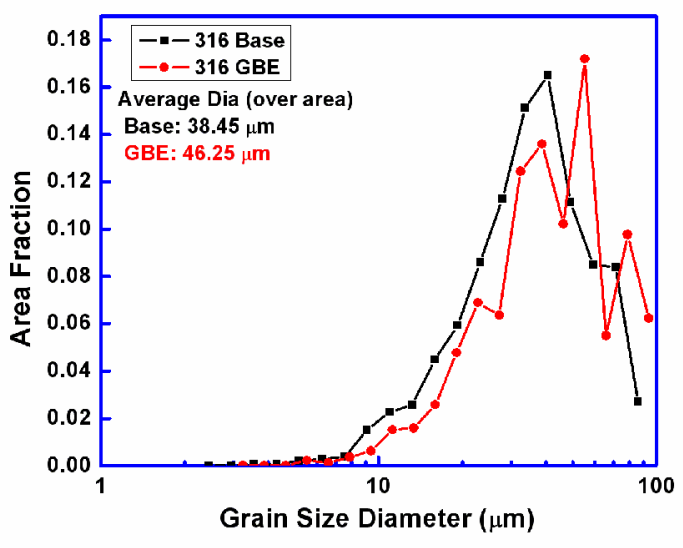

$316 \mathrm{SS}$

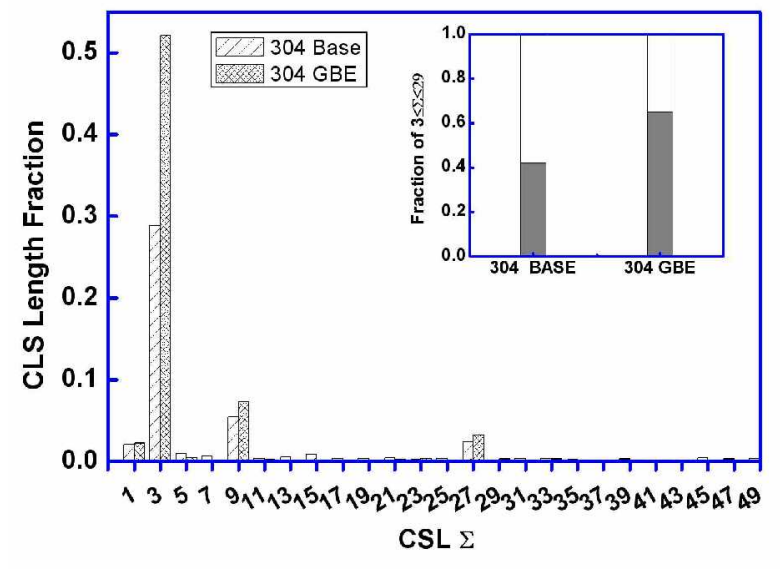

304 SS

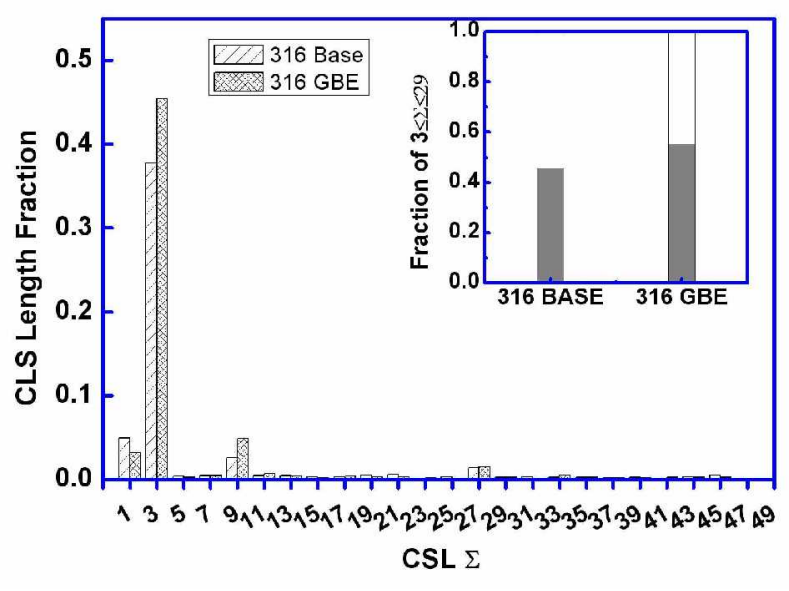

$316 \mathrm{SS}$

Figure 80. Grain size distribution (left) and CSL length fraction (right) for GBE and non-GBE Type 304 and 316 SSs 


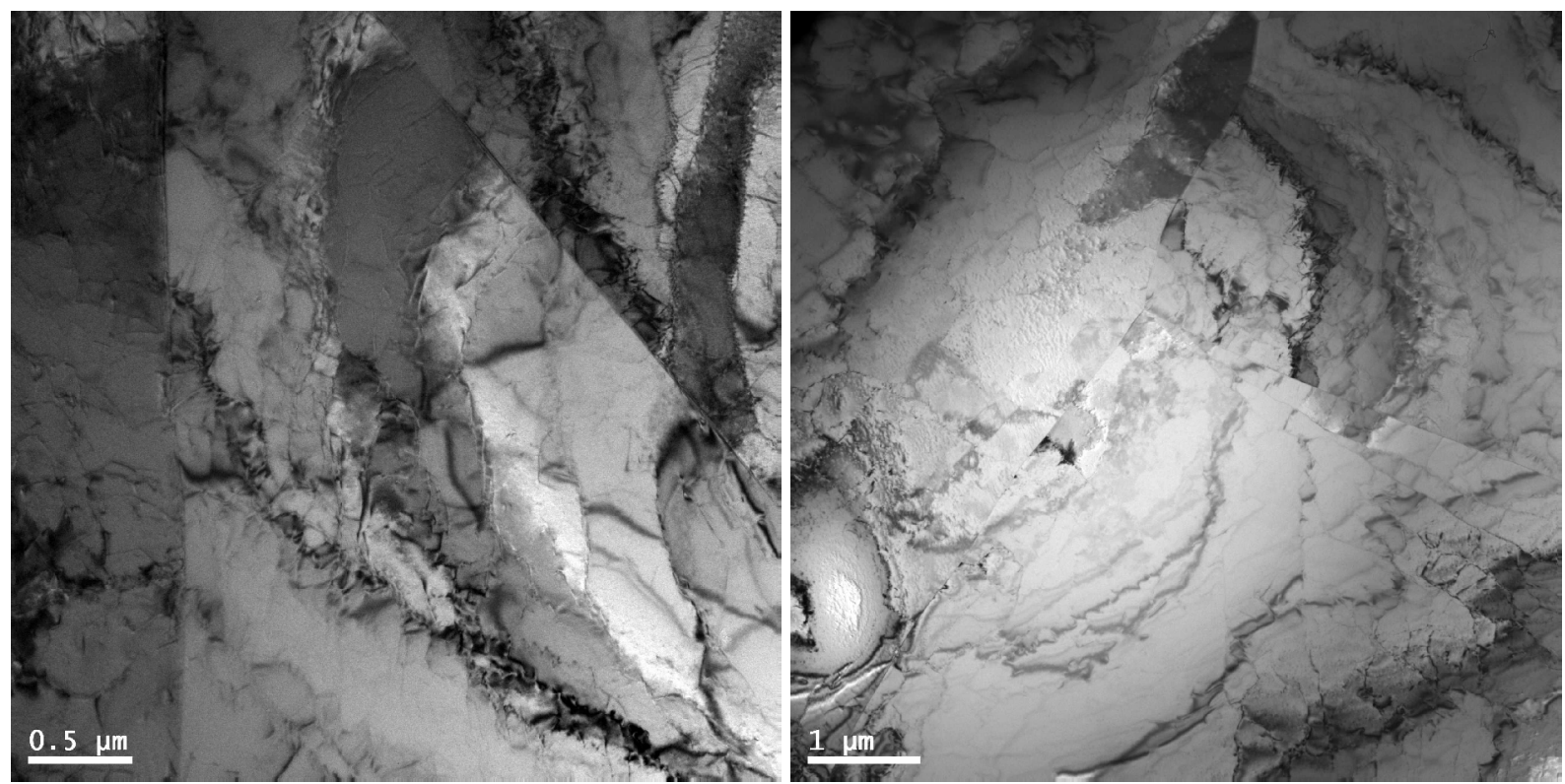

(a) non-GBE Type $316 \mathrm{SS}$
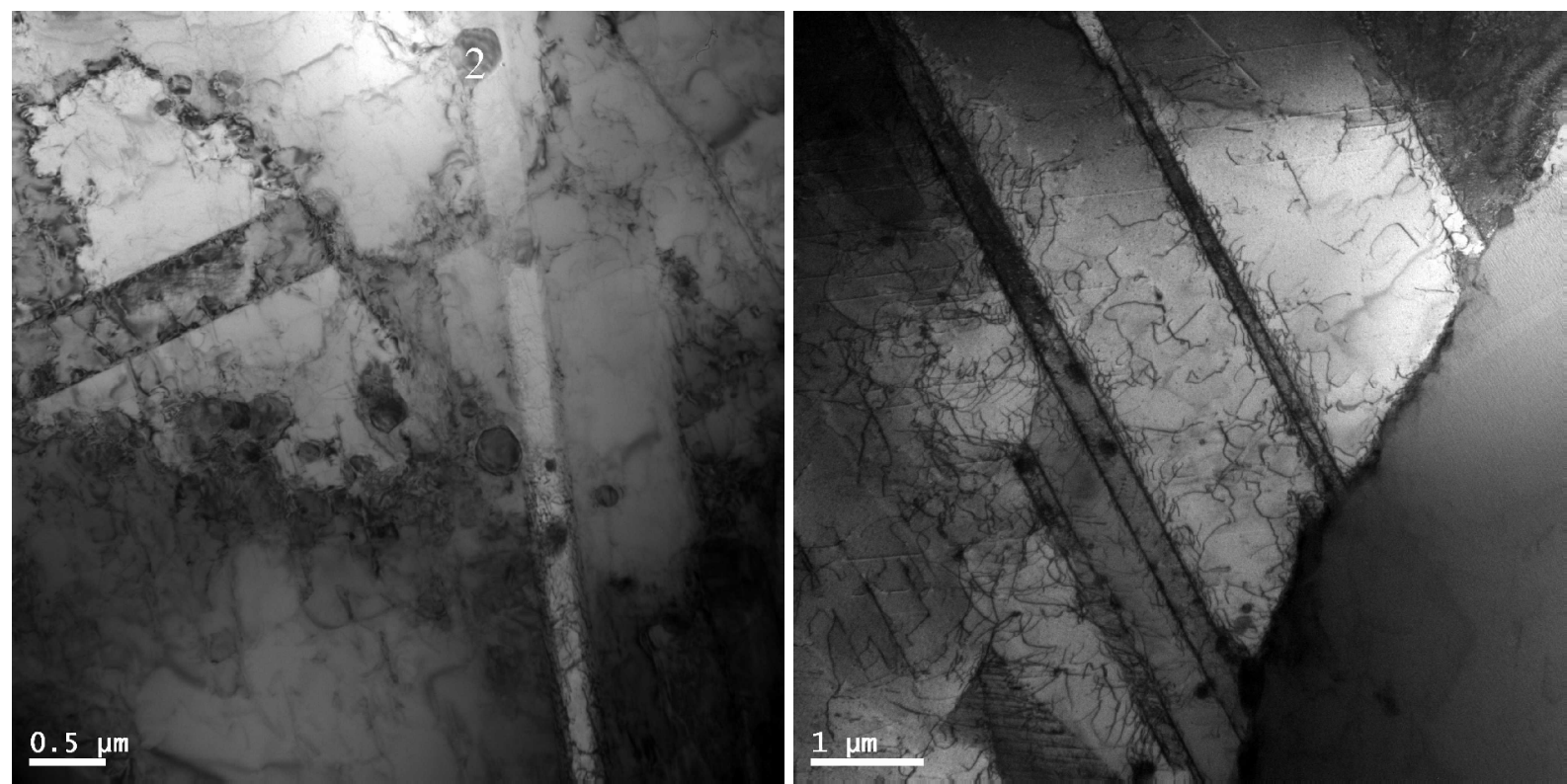

(b) GBE Type $316 \mathrm{SS}$

Figure 81. Transmission electron microscopy images for (a) non-GBE and (b) GBE Type 316 SSs.

Both GBE 316 and 304 SSs showed unfavorable microstructure (e.g. precipitation, or large grain size) that is known to be critical to IASCC susceptibility. This vulnerable microstructure may indicate a poorly handled GBE process. The thermomechanical treatment employed may also have introduced sensitization in the alloys. It appears that the potential benefit resulting from the increased CSL boundaries to $\approx 60 \%$ is insufficient to offset the detrimental effects caused by the susceptible microstructure (e.g. large grain size, precipitation) in Types 304 and 316 SSs. The ineffectiveness of the applied GBE treatment suggests that the beneficial effect warranted by a higher fraction of CSL boundaries may be secondary for limiting crack propagation in austenitic SSs. Other detrimental effects 
introduced by large grain size or brittle precipitates may be more important in determining the rate of crack growth. The beneficial effects of GBE treatment on CGRs have to be evaluated with higher CSL fractions in austenitic SSs. Any practical use of GBE SSs will require the development of procedures to better control GBE treatment.

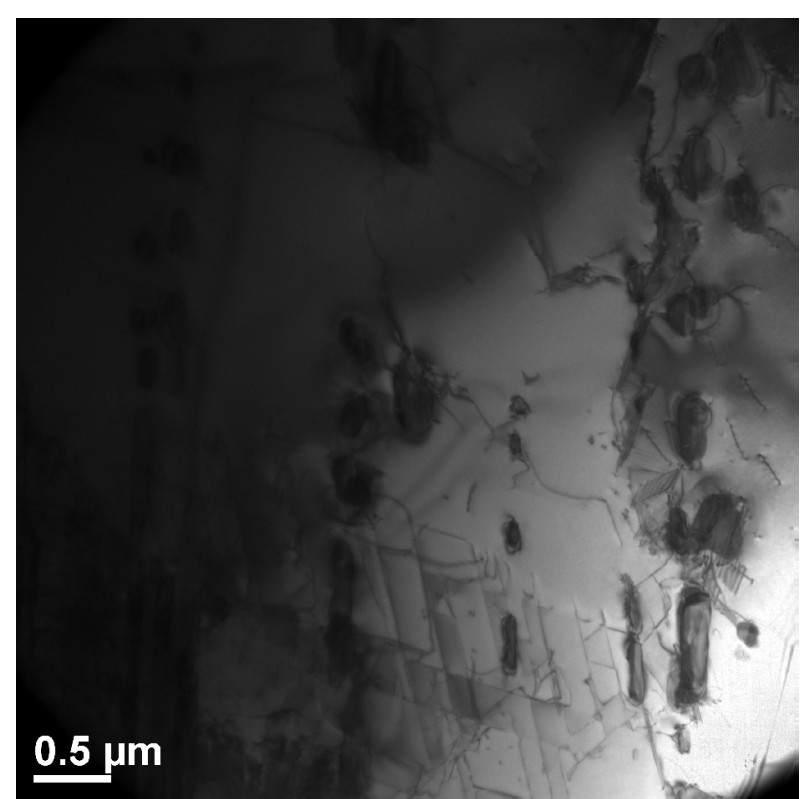

(a)

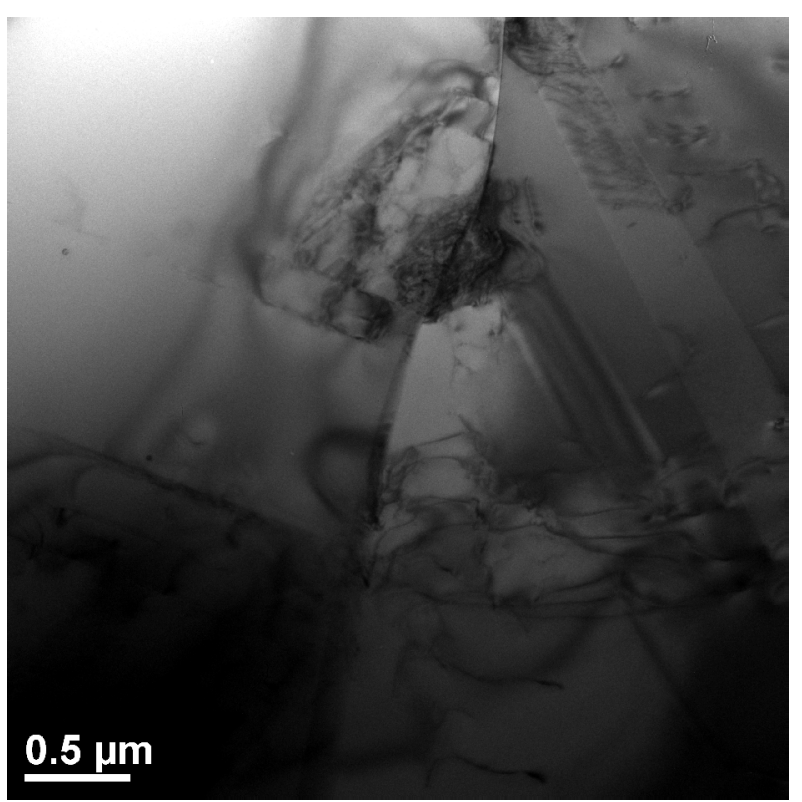

(b)

Figure 82. TEM images for (a) non-GBE and (b) GBE 304 SSs. 
This page is intentionally left blank. 


\section{Summary}

Crack growth rate tests have been conducted in simulated BWR environments on 1/4T-CT specimens of Type 304L SA and 304 SMA weld HAZ, sensitized Type 304 SS, and Type 304 and 316 SSs with and without GBE treatment. The specimens were irradiated in the Halden reactor to 0.75 and $\approx 2$ dpa. Based on the cyclic and constant-load CGR results, IASCC susceptibility was evaluated for the tested materials as a function of neutron dose, processing conditions, and water chemistry. Fracture toughness tests were also carried out in the BWR environment after the CGR tests. Combining the present results with those from Halden-I and -II tests, we analyzed the effects of neutron dose, water chemistry, alloy compositions, and welding and processing conditions on IASCC. The effect of neutron irradiation on the fracture toughness of the tested materials was also evaluated at dose levels relevant to BWR internals. The major findings of this investigation are as follow:

(1) Crack growth tests require a K-dominated loading condition to ensure the test results are independent of specimen size and geometry. A K/size criterion is, therefore, required to maintain a minimum constraint in front of a crack tip. In the present study, the effect of strain softening, exhibited by high-dose specimens, on the plastic zone size was analyzed. Assuming 20\% strainsoftening, the plastic zone size was determined to be only $11 \%$ larger than that required by the ASTM standard E-399 for fracture toughness tests. This analysis confirmed that the $\mathrm{K} / \mathrm{size}$ criterion is satisfied in most of the tests conducted in the present study.

(2) Neutron irradiation elevated the cyclic CGRs significantly for all HAZ specimens at all dose levels regardless of weld type and as-welded or thermally treated conditions. The constant-load CGRs for as-welded SA and SMA HAZ were about 8-10 times higher than the NUREG-0313 curve. A postweld heat treatment at $500^{\circ} \mathrm{C}$ for 24 hours did not affect the constant-load CGRs of the irradiated HAZ specimens significantly. Fracture toughness of thermally treated HAZ specimens was slightly lower than that of as-welded HAZ materials. In general, the effect of low-temperature sensitization appears to be insignificant for the IASCC susceptibility of HAZ materials for both SA and SMA welds.

(3) Type $304 \mathrm{SS}$ specimens were thermally sensitized at $600^{\circ} \mathrm{C}$ for $10.5 \mathrm{~h}$ and $24 \mathrm{~h}$ to investigate the effect of degree of sensitization on IASCC. The specimens sensitized at the two conditions showed similar cracking behavior under both cyclic and constant-load test conditions. The degree of sensitization appears to play a less significant role in the cracking susceptibility of irradiated compared with nonirradiated materials. Irradiation effects appear to be the dominating factor for IASCC behavior.

(4) The influence of material type and material chemistry on IASCC susceptibility was evaluated by analysis of CGR and SSRT results obtained from previous Halden studies. For CGR tests, cyclic and constant-load CGRs of three austenitic SSs were compared at three dose levels in NWC and HWC. Within the scatter of the data, IASCC susceptibility appears to be insensitive to the material type in NWC. A comparison of CGRs in HWC was inconclusive because of the concern over invalidation of the $\mathrm{K} /$ size criterion. Significantly higher load was required to achieve some measurable CGRs in tests performed in HWC. For SSRT tests, the fraction of intergranular cracking was used to characterize the IASCC susceptibility of different alloys. The SSRT results indicated that minor alloying elements such as carbon, sulfur, oxygen, and silicon may play an important role in the IASCC process. Low-carbon and high-sulfur SSs were found to be prone to IASCC. Sulfur content below 0.002 wt.\% was found to be critical for IASCC resistance in 
austenitic SSs in high-DO BWR water. The effect of alloying element must be addressed in the context of radiation-induced segregation.

(5) Stress corrosion cracking is a strong function of corrosion potential. It has been repeatedly demonstrated that a low corrosion potential can effectively mitigate IASCC. In our analysis, both cyclic and constant-load CGR results showed at least one order of magnitude reduction in HWC compared with NWC. However, a few tests conducted in the high-K range showed that the beneficial effect of HWC is absent in some high-dose specimens ( $>3 \mathrm{dpa})$. This unusual cracking behavior in HWC has often been explained with respect to the $\mathrm{K} /$ size criterion. Nonetheless, the insensitiveness to low corrosion potential demonstrated by some high-dose specimens should not be overlooked based solely on the loading condition. Several tests conducted under the validated Kconstraint condition have shown the HWC beneficial effect to be lost with Type 304L SS at doses as low as $3 \mathrm{dpa}$. Since the dose dependence of the HWC effect is poorly understood, additional data are needed for dose greater than 3 dpa.

(6) Halden-I crack growth results in NWC at three doses were used to illustrate the dose dependence of IASCC behavior. A trend of increased environmental enhancement with dose could be seen with the cyclic CGRs for this group of specimens. The constant-load CGRs of these specimens also increased sharply between 0.45 and $1.35 \mathrm{dpa}$. Above $1.35 \mathrm{dpa}$, the increasing trend of the constantload CGR became slower. Fracture toughness of austenitic SSs also decreased rapidly with neutron dose. The threshold dose for a sharp decrease in fracture toughness is about $0.3 \mathrm{dpa}$, and little plasticity is expected prior to fracture for austenitic SSs above 5 dpa.

(7) Crack growth tests were performed on irradiated GBE and non-GBE Types 304 and 316 SSs in simulated BWR water environments. A beneficial effect on IASCC resistance was not readily revealed in these alloys with about $60 \%$ CSL boundaries. Microstructure examination on the nonirradiated GBE and non-GBE materials showed significant precipitation and large grain size in the GBE alloys. The ineffectiveness of GBE treatment demonstrated in the present study suggests that the beneficial effect provided by a high fraction of CSL boundaries may be overwhelmed by detrimental effects introduced by brittle precipitates or large grain size.

Future work for IASCC study in BWR environment should be focused on high-dose specimens $\left(>2 \times 10^{21} \mathrm{n} / \mathrm{cm}^{2},>3 \mathrm{dpa}\right)$ in HWC. At present, crack growth rate data for irradiated SSs at high doses are scarce and the dose-dependence of the effect of HWC on IASCC behavior is not clear. While it is clear that there is a beneficial effect of HWC on CGR for nonirradiated and low-dose $(<3 \mathrm{dpa}) \mathrm{SSs}$, it is not clear that the same degree of mitigation occurs for materials at higher doses. Cracking and deformation mechanisms must remain the same with increasing dose for HWC to be as effective. The assumption that HWC is equally effective at higher doses may not necessarily be true because irradiation hardening, loss of ductility and work hardening behavior continue to evolve beyond 3 dpa in SSs. Additional work is thus needed to further characterize the effectiveness of HWC at high doses. 


\section{References}

1. Suess, S. J., "Case Histories Involving Stress Corrosion Cracking of Various Alloys," Corrosion, 64 (5), 401, 2008.

2. Dayal, R. K., N. Parvathavarthini and Baldev Raj, "Influence of Metallurgical Variables on Sensitization Kinetics in Austenitic Stainless Steels”, Inter. Mater. Rev., 50 (3), 129, 2005.

3. NRC Generic Letter 94-03, "Intergranular Stress Corrosion Cracking of Core Shrouds in Boiling Water Reactors," U.S. Nuclear Regulatory Commission, July 25, 1994.

4. NRC Information Notice 92-57, "Radial Cracking of Shroud Support Access Hole Cover Welds," U.S. Nuclear Regulatory Commission, August 11, 1992.

5. NRC IE Bulletin No. 80-07, "BWR Jet Pump Assembly Failure," U.S. Nuclear Regulatory Commission, April 4, 1980.

6. $\quad$ NRC Information Notice 93-101, “Jet Pump Hold-Down Beam Failure,” U.S. Nuclear Regulatory Commission, December 17, 1993.

7. NRC Information Notice 97-02, "Cracks Found in Jet Pump Riser Assembly Elbows at Boiling Water Reactors," U.S. Nuclear Regulatory Commission, February 6, 1997.

8. NRC Information Notice 95-17, "Reactor Vessel Top Guide and Core Plate Cracking," U.S. Nuclear Regulatory Commission, March 10, 1995.

9. NUREG-1544, "Status Report: Intergranular Stress Corrosion Cracking of BWR Core Shrouds and Other Internal Components,” U.S. Nuclear Regulatory Commission, March 1996.

10. NRC Information Notice 98-11, "Cracking of Reactor Vessel Internal Baffle Former Bolts in Foreign Plants,” U.S. Nuclear Regulatory Commission, March 25, 1998.

11. Garner, F. A., "Evolution of Microstructure in Face-Centered Cubic Metals during Irradiation," J. Nucl. Mater., 205, 98-117, 1993.

12. Maziasz, P.J., "Overview of Microstructural Evolution in Neutron-Irradiated Austenitic Stainless Steels," J. Nucl. Mater., 205, 118-145, 1993.

13. Zinkle, S.J., P.J. Maziasz, and R. E. Stoller, "Dose Dependence of the Microstructure Evolution in Neutron-Irradiated Austenitic Stainless Steel,” J. Nucl. Mater., 206, 266-286, 1993.

14. Okamoto, P.R., and L. E. Rehn, "Radiation-Induced Segregation in Binary and Ternary Alloys," J. Nucl. Mater., 83, 2-23, 1979.

15. Bruemmer, S. M, E. P. Simonen, P. M. Scott, P. L. Andresen, G. S. Was, and J. L. Nelson, "Radiation-Induced Material Changes and Susceptibility to Intergranular Failure of Light-WaterReactor Core Internals,” J. Nucl. Mater., 274, 299-314, 1999. 
16. Scott, P., “A Review of Irradiation Assisted Stress Corrosion Cracking," J. Nucl. Mater., 211, 101-122, 1994.

17. Bruemmer, S. M., and Gary S. Was, "Microstructural and Microchemical Mechanisms Controlling Intergranular Stress Corrosion Cracking in Light-Water-Reactor Systems," J. Nucl. Mater., 216, 348-363, 1994.

18. Was, G. S., and P. L. Andresen, "Stress Corrosion Cracking Behavior of Alloys in Aggressive Nuclear Reactor Core Environments," Corrosion, 63 (1), 19-45, 2007.

19. Chopra, O. K., B. Alexandreanu, E. E. Gruber, R. S. Daum, and W. J. Shack, "Crack Growth Rates of Irradiated Austenitic Stainless Steel Weld Heat Affected Zone in BWR Environments," NUREG/CR-6891, ANL-04/20, January 2006.

20. Chopra, O. K., and W. J. Shack, "Crack Growth Rates and Fracture Toughness of Irradiated Austenitic Stainless Steels in BWR Environments,” NUREG/CR-6960, ANL-06/58, 2008.

21. Jacobs, A. J., G. P. Wozadlo, K. Nakata, T. Yoshida, and I. Masaoka, "Radiation Effects on the Stress Corrosion and Other Selected Properties of Type-304 and Type-316 Stainless Steels," Proc. 3rd Intl. Symp. Environmental Degradation of Materials in Nuclear Power Systems--Water Reactors, G. J. Theus and J. R. Weeks, eds., The Metallurgical Society, Warrendale, PA, pp. 673-680, 1988.

22. Gordon, G. M. and K. S. Brown, "Dependence of Creviced BWR Component IGSCC Behavior on Coolant Chemistry," Proc. 4th Intl. Symp. on Environmental Degradation of Materials in Nuclear Power Systems--Water Reactors, NACE, Houston, TX, pp. 14.46-14.62, 1990.

23. Garzarolli, F., D. Alter, P. Dewes, and J. L. Nelson, "Deformability of Austenitic Stainless Steels and Ni-Base Alloys," Proc. 3rd Intl. Symp. on Environmental Degradation of Materials in Nuclear Power Systems--Water Reactors, G. J Theus and J. R. Weeks, eds., The Metallurgical Society, Warrendale, PA, pp. 657-664, 1988.

24. Chung, H. M., R. V. Strain, and R. W. Clark, "Slow-Strain-Rate-Tensile Test of Model Austenitic Stainless Steels Irradiated in the Halden Reactor," in Environmentally Assisted Cracking in Light Water Reactors Semiannual Report July 2000-December 2000, NUREG/CR-4667, Vol. 31, ANL-01/09, pp. 22-32, 2002.

25. Kodama, M., R. Katsura, J. Morisawa, S. Nishimura, S. Suzuki, K. Asano, K. Fukuya, and K. Nakata, "IASCC Susceptibility of Austenitic Stainless Steels Irradiated to High Neutron Fluence," Proc. Sixth Intl. Symp. on Environmental Degradation of Materials in Nuclear Power Systems-Water Reactors, R. E. Gold and E. P. Simonen, eds., Minerals, Metals \& Materials Society, Warrendale, PA, pp. 583-588, 1993.

26. Clark, W. L., and A. J. Jacobs, "Effect of Radiation Environment on SCC of Austenitic Materials," Proc. First Intl. Symp. on Environmental Degradation of Materials in Nuclear Power Systems -Water Reactors, NACE, Houston, TX, p. 451, 1983. 
27. Andresen, P. L., F. P. Ford, S. M. Murphy, and J. M. Perks, "State of Knowledge of Radiation Effects on Environmental Cracking in Light Water Reactor Core Materials," Proc. 4th Intl. Symp. on Environmental Degradation of Materials in Nuclear Power Systems--Water Reactors, NACE, Houston, TX, pp. 1.83-1.121, 1990.

28. Jenssen, A., and L. G. Ljungberg, "Irradiation Assisted Stress Corrosion Cracking of Stainless Alloys in BWR Normal Water Chemistry and Hydrogen Water Chemistry," Proc. Sixth Intl. Symp. on Environmental Degradation of Materials in Nuclear Power Systems -- Water Reactors, R. E. Gold and E. P. Simonen, eds., Minerals, Metals \& Materials Society, Warrendale, PA, p. 547, 1993.

29. Cowan, R. L., and E. Kiss, "Optimizing BWR Water Chemistry," Proc. Sixth Intl. Symp. on Environmental Degradation of Materials in Nuclear Power Systems -- Water Reactors, R. E. Gold and E. P. Simonen, eds., Minerals, Metals \& Materials Society, Warrendale, PA, p. 889, 1993.

30. Fukuya, K., M. Nakano, K. Fujii, M. Kodama, and T. Torimaru, "Effects of Post-irradiation Annealing on Radiation-Induced Material Changes and IASCC Susceptibility in PWR-irradiated Stainless Steels," Proc. 11th Int. Conf. Environmental Degradation of Materials in Nuclear Systems, Stevenson, WA, p.1153, August 10-14, 2003

31. Conermann, J., R. Shogan, K. Fujimoto, T. Yonezawa, and Y. Yamaguchi, "Irradiation Effects in a Highly Irradiated Cold Worked Stainless Steel removed from a Commercial PWR," Proc. $12^{\text {th }}$ Int. Conf. Environmental Degradation of Materials in Nuclear Systems, Minerals, Metals \& Materials Society, p. 277, 2005.

32. Osozawa, K., and H. J. Engell, "The Anodic Polarization Curves of Iron-Nickel-Chromium Alloys,” Corr. Sci., 6, 389-393, 1966.

33. Tedmon, C. S., Jr., D. A. Vermilyea, and J. H. Rosolowski, "Intergranular Corrosion of Austenitic Stainless Steel,” J. Electrochem. Soc., 118, 192-202, 1971.

34. Bruemmer S. M., L. A. Charlot, and D. G. Atteridge, "Sensitization Development in Austenitic Stainless Steel: Measurement and Prediction of Thermomechanical History Effects," Corrosion, 44, 427, 1987.

35. Busby, J. T., and G. S. Was, "Irradiation-Assisted Stress Corrosion Cracking in Model Alloys with Solute Additions," Proc. 11th Int. Symp. on Environmental Degradation of Materials in Nuclear Power Systems--Water Reactors, NACE, Houston, TX, pp. 995-1014, 2003.

36. Was, G. S., "Recent Developments in Understanding Irradiation Assisted Stress Corrosion Cracking," Proc. 11th Int. Symp. on Environmental Degradation of Materials in Nuclear Power Systems--Water Reactors, NACE, Houston, TX, pp. 965-985, 2003.

37. Gertsman, V. Y., and K. Tangri, "Grain Boundary Distributions, Texture and Orientation Correlations in Austenitic Stainless Steels," Scripta Metallurtica et Materialia, 33 (7), 1037-1042, 1995.

38. Lin, P., G. Palumbo, U. Erb, and K. T. Aust, "Influence of Grain Boundary Character Distribution on Sensitization and Intergranular Corrosion of Alloy 600," Scripta Metallurtica et Materialia, 33 (9), 1387-1392, 1995. 
39. Was, G. S., B. Alexandreanu, P. Andresen, and M. Kumar, "Role of Coincident Site Lattice Boundaries in Creep and Stress Corrosion Cracking," Proc. Interfacial Engineering for Optimized Properties III, Materials Research Society Symposium Proceedings, Vol. 819, pp. 87-100, 2004.

40. Watanabe, T., "Approach to Grain Boundary Design for Strong and Ductile Polycrystals," Res. Mechanica: Inter. J. Struct. Mech. Mater. Sci., 11 (1), 47-84, 1984.

41. Randle, V., "Twinning-Related Grain Boundary Engineering," Acta Materialia 52, 4067-4081, 2004.

42. Kim, H. M., and J. A. Szpunar, "The Effect of Texture and Grain Boundary Structure on the Intergranular Corrosion of Stainless Steel,” Mat. Sci. Forum, 157-162, 1997-2004, 1994.

43. Palumbo, G., E. M. Lehockey, and P. Lin, "Applications for Grain Boundary Engineered Materials," JOM, 50 (2), 40-43, 1998.

44. Was, G. S., V. Thaveeprungsriporn, and D. C. Crawford, "Grain Boundary Misorientation Effects on Creep and Cracking in Ni-Based Alloys,” JOM, 50 (2), 44-49, 1998.

45. Randle, V., and G. Owen, "Mechanisms of Grain Boundary Engineering," Acta Materialia, 54, 1777-1783, 2006.

46. Michaud, W. F., P. T. Toben, W. K. Soppet, and O. K. Chopra, "Tensile-Property Characterization of Thermally Aged Cast Stainless Steels,” NUREG/CR-6142, ANL-93/35, 1994.

47. Joyce, J. A., and R. L. Tregoning, "Development of Consistent Size Criteria for ASTM Combined Fracture Mechanics Standards," in Fatigue and Fracture Mechanics, Vol. 30, ASTM STP 1360, ASTM, West Conshokocken, PA, 1999.

48. Shack W. J., and T. F. Kassner, "Review of Environmental Effects on Fatigue Crack Growth of Austenitic Stainless Steels,” NUREG/CR-6176, ANL-94/1, 1994.

49. James, L. A., and D. P. Jones, "Fatigue Crack Growth Correlation for Austenitic Stainless Steels in Air," Proc. Conf. on Predictive Capabilities in Environmentally-Assisted Cracking, PVP Vol. 99, R. Rungta, ed., American Society of Mechanical Engineers, New York, pp. 363-414, 1985.

50. Hazelton, W. S., and W. H. Koo, "Technical Report on Material Selection and Processing Guidelines for BWR Coolant Pressure Boundary Piping, Final Report," NUREG-0313, Rev. 2, 1988.

51. Balladon, P., J. Heritier, and P. Rabbe, "Influence of Microstructure on the Ductile Rupture Mechanisms of a 316L Steel at Room and Elevated Temperatures," Fracture Mechanics: $14^{\text {th }}$ Symp., Vol. II: Testing and Applications, American Society for Testing and Materials, STP 791, ASTM, Philadelphia, PA, pp 496-516, 1983.

52. Mills, W. J., "On the Relationship between Stretch Zone Formation and the J Integral for High Strain-Hardening Materials”, J. Test. Eval., 9, 56-62, 1981.

53. Brown, W. F., Jr., and J. E. Srawley, "Plane Strain Crack Toughness Testing of High Strength Metallic Materials," American Society for Testing and Materials, STP 410, 1966. 
54. ASTM International, "Standard Test for Plane-Strain Fracture Toughness of Metallic Materials," E399-90, Annual Book of ASTM Standards, 1997

55. ASTM International, "Standard Test Method for Measure of Fracture Toughness," E1820-06, http://www.astm.org, 2006

56. Anderson, T. L., Fracture Mechanics: Fundamentals and Applications, $3^{\text {rd }}$ ed.,Taylor \& Francis, Boca Raton, FL, 2005.

57. Suresh, S., Fatigue of Materials, Cambridge University Press, Cambridge, England, 1998.

58. Irwin, G. R., "Plastic Zone near a Crack and Fracture Toughness," Proc. $7^{\text {th }}$ Sagamore Ordnance Materials Conference, Syracuse University, Vol. IV., pp. 63-78, 1960.

59. Andresen, P. L., "K/Size Effects on SCC in Irradiated, Cold-Worked and Unirradiated Stainless Steel," $11^{\text {th }}$ Int. Conf. Environmental Degradation of Materials in Nuclear Systems, Stevenon, WA, August 10-14, 2003.

60. Jenssen, A., K. Gott, P. Efsing, and P. O. Andersson, "Crack Growth Behavior of Irradiated Type 304L Stainless Steel in Simulated BWR Environment," Proc. 11th Intl. Symp. on Environmental Degradation of Materials in Nuclear Power Systems--Water Reactors, pp. 10151024, 2003.

61. Andresen, P.L., F.P. Ford, J. P. Higgins, I. Suzuki, M. Koyama, M. Akiyama, T. Okubo, Y. Mishima, S. Hattori, H. Anzai, H. Chujo, and Y. Kanazawa, "Life Prediction of Boiling Water Reactor Internals," Proc. ASME-JSME $4^{\text {th }}$ International Conference on Nuclear Engineering (ICONE-4), pp. 461-473, 1996.

62. Richey, E., D. S. Morton and W. C. Moshier, "Influence of Specimen Size on the SCC Growth Rate of Ni-Alloys Exposed to High Temperature Water," Paper 06513, Corrosion/06, NACE, Houston, TX, 2006.

63. Sumiya1, Rie, Shigeaki Tanaka, Kiyotomo Nakata, Kenichi Takakura, Masami Ando, Tadahiko Torimaru, and Yuji Kitsunai, "K Validity Criterion of Neutron Irradiated Type 316L Stainless Steel CT Specimen for SCC Growth Test," 13th Int. Conf. on Environmental Degradation of Materials in Nuclear Power Systems, Whistler, British Columbia, August 19-23, 2007.

64. Nakamura1, T., M. Koshiishi1, T. Torimaru, Y. Kitsunai, K. Takakura, K. Nakata, M. Ando, Y. Ishiyama, and A. Jenssen, "Correlation between IASCC Growth Behavior and Plastic Zone Size of Crack Tip in 3.5 dpa Neutron Irradiated Type 304L SS CT Specimen," 13th Int. Conf. on Environmental Degradation of Materials in Nuclear Power Systems, Whistler, British Columbia, August 19-23, 2007.

65. Bamford, W. H., and A. J. Bush, "Fracture Behavior of Stainless Steel," in Elastic-Plastic Facture, American Society for Testing and Materials, STP 668, p. 553, 1979.

66. Dufresne, J., B. Henry, and H. Larsson, "Fracture Toughness of Irradiated AISI Type 304 and 316L Stainless Steels," in Effects of Radiation and Structural Materials, American Society for Testing and Materials, STP 683, p.511, 1979. 
67. Marshall, P., Austenitic Stainless Steels, Microstructure and Mechanical Properties, Elsevier Applied Science, London, 1984.

68. Chopra, O. K., E. E. Gruber, and W. J. Shack, "Fracture Toughness and Crack Growth Rates of Irradiated Austenitic Stainless Steels,” NUREG/CG-6826, ANL-03/22, August 2003.

69. Chung, H. M., W. R. Ruther, R. V. Strain, and W. J. Shack, "Irradiation-Assisted Stress Corrosion Cracking of Model Austenitic Stainless Steel Alloys," NUREG/CR-6687, ANL-00/21, October 2000.

70. Chung, H. M. and W. J. Shack, "Irradiation-Assisted Stress Corrosion Cracking Behavior of Austenitic Stainless Steels Applicable to LWR Core Internals," NUREG/CR-6892, ANL-04/10, January 2006.

71. Chen, Y., O. K. Chopra, W. K. Soppet, N. L. Dietz Rago, W.J. Shack, "Irradiation-Assisted Stress Corrosion Cracking of Austenitic Stainless Steels and Alloy 690 from Halden Phase-II Irradiations," NUREG/CR 6965, ANL-07/11, September 2008.

72. Chen, Y., O. K. Chopra, W. K. Soppet, N. L. Dietz Rago, and W. J. Shack, "IASCC Susceptibility of Austenitic Stainless Steels and Alloy 690 in High Dissolved Oxygen Water Environment," 13th Int. Conf. on Environmental Degradation of Materials in Nuclear Power Systems, Whistler, British Columbia, August 19-23, 2007.

73. Flewitt P. E. J., and R. K. Wild, Grain Boundaries, Their Microstructure and Chemistry, John Wiley \& Sons, LTD., Chichester, 2001.

74. Jenssen, A., L. G. Ljungberg, J. Walmsley, and S. Fisher, "Importance of Molybdenum on Irradiation-Assisted Stress Corrosion Cracking in Austenitic Stainless Steels," Corrosion, 54 (1), 48-60, 1998.

75. Cole, J. I., T. R. Allen, G. S. Was, Y. Wang, and E. A. Kenik, "The Effect of Bulk Composition on the Radiation-Induced Microstructures and Segregation Behavior in Model Austenitic Stainless Steel Alloys: A Proton Irradiation Study," Proc. Tenth Intl. Symp. on Environmental Degradation of Materials in Nuclear Power Systems--Water Reactors, NACE, Houston, TX, 2001.

76. Cookson, J. M., G. S. Was, and P. L. Andresen, "Oxide-Induced Initiation of Stress Corrosion Cracking in Irradiated Stainless Steels," Corrosion, 54 (4), 48-60, 1998.

77. Andresen, P. L., and M. M. Morra, "Effects of Si on SCC of Irradiated and Unirradiated Stainless Steels and Nickel Alloys," Proc. 12th Int. Symp. on Environmental Degradation of Materials in Nuclear Power Systems - Water Reactors, Minerals, Metals \& Materials Society, Warrendale, PA, 2005 .

78. Andresen, P. L., and M. M. Morra, "Emerging Issues in Environmental Cracking in Hot Water," 13th Int. Symp. on Environmental Degradation of Materials in Nuclear Power Systems, Whistler, British Columbia, August 19-23, 2007.

79. Bruemmer, S. M, T. F. Soran, J. I. Cole, B. W. Arey, L. A. Charlot, and C. F. Windisch, Jr., "Radiation-Induced Segregation of Impurities and Effects on the Electrochemistry of Nickel and Stainless Steel," paper 420, Corrosion/95, paper 420, NACE, Huston, 1995 
80. Ford, P., and P. Andresen, "Development and Use of a Predictive Model of Crack Propagation in 304/316L. A533/A508 and Inconel 600/182 Alloys in $288^{\circ} \mathrm{C}$ Water," Proc. 3rd Int. Symp. on Environmental Degradation of Materials in Nuclear Power Systems--Water Reactors, G. J. Theus and J. R. Weeks, eds., Minerals, Metals \& Materials Society, Warrendale, PA, 1988.

81. Andresen, P., "Modeling of Water and Material Chemistry Effects on Crack Tip Chemistry and Resulting Crack Growth Kinetics," Proc. 3rd Int. Symp. on Environmental Degradation of Materials in Nuclear Power Systems--Water Reactors, G. J. Theus and J. R. Weeks, eds., Minerals, Metals \& Materials Society, Warrendale, PA, 1988.

82. Andresen, P. L., "Similarity of Cold Work and Radiation Hardening in Enhancing Yield Strength and SCC Growth of Stainless Steel in Hot Water," Paper No. 02509, Corrosion/02, NACE, Houston, TX, Paper No. 02509, 2002.

83. Karlsen, T. M., P. Bennett, and N. W. Hogberg, "In-Core Crack Growth Rate Studies on Irradiated Austenitic Stainless Steels in BWR and PWR Conditions in the Halden Reactor," Proc. 12th Intl. Conf. on Environmental Degradation of Materials in Nuclear Power Systems--Water Reactors, T. R. Allen, P. J. King, and L. Nelson, eds., Minerals, Metals \& Materials Society, Warrendale, PA, pp. 337-348, 2005. 